UNIVERSIDADE DE SÃO PAULO

FACULDADE DE FILOSOFIA, LETRAS E CIÊNCIAS HUMANAS

DEPARTAMENTO DE LETRAS CLÁSSICAS E VERNÁCULAS

PROGRAMA DE PÓS-GRADUAÇÃO EM LETRAS CLÁSSICAS

\title{
As pinturas do templo de Juno e o Ciclo Troiano \\ - imagem e memória épica na arquitetura da Eneida -
}

Francisco Edi de Oliveira Sousa

Tese apresentada ao Programa de Pós-Graduação em Letras Clássicas, do Departamento de Letras Clássicas e Vernáculas da Faculdade de Filosofia, Letras e Ciências Humanas da Universidade de São Paulo, em co-tutela com a Université de ParisSorbonne (Paris IV).

Orientador na USP: Profa. Dra. Zélia Ladeira Veras de Almeida Cardoso Orientador na Sorbonne: Prof. Dr. Carlos Lévy

São Paulo 


\section{ÍNDICE}

Introdução $\quad 05$

Capítulo I: Os poemas perdidos do ciclo troiano 11

$\begin{array}{ll}\mathrm{O} \text { ciclo troiano } & 12\end{array}$

Cantos Cíprios 16

Etíope 31

Pequena Ilíada 38

Saque de Ílion $\quad 45$

Retornos $\quad 52$

Telegonia 57

$\begin{array}{ll}\text { Conclusão do capítulo } & 60\end{array}$

Capítulo II: As pinturas do templo de Juno e as epopéias do ciclo troiano 66

II.1 - Alusão das imagens a épicos do ciclo troiano 73

II.1.1 - Imagem I (v. 458 e 461) 73

II.1.2 - Imagens II e III (v. 466-468) 78

II.1.3 - Imagem IV (v. 469-473) 79

II.1.4 - Imagem V (v. 474-478) 81

II.1.5 - Imagem VI (v. 479-482) 85

II.1.6 - Imagem VII (v. 483-487) 87

II.1.7 - Imagens VIII (v. 488), IX (v. 489) e X (v. 490-493) 92

II.2 - Disposição das imagens 99

II.2.1 - Parte prima 102

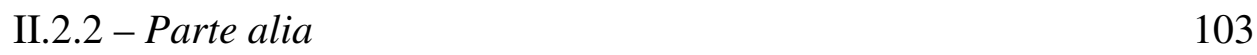

II.3 - A arte da memória no episódio das pinturas do templo de Juno 112

$\begin{array}{ll}\text { Conclusão do capítulo } & 118\end{array}$

Capítulo III: A arquitetura dos seis cantos iniciais da Eneida e o ciclo troiano $\quad 119$

III.1 - A instituição de uma arquitetura fundada no ciclo troiano 129

III.2 - A queda de Tróia 131

III.2.1 - A deliberação e a entrada do cavalo em Tróia 134 
III.2.2 - Sínon

III.2.3 - Laocoonte e a permanência de Enéias em Tróia durante o saque

III.2.4 - Enéias

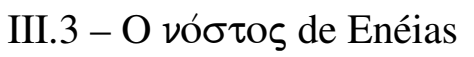

140

III.3.1 - Canto III

140

III.3.1.1 - O destino distinto dos ramos de Dárdano e a fuga para o monte Ida

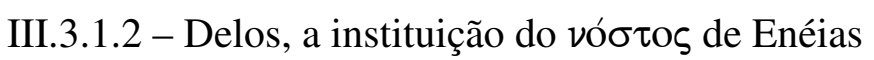

III.3.1.3 - Em Creta, a Eneida encontra os Retornos

III.3.1.4 - Mergulho em águas da Odisséia

III.3.1.5 - As harpias

III.3.1.6 - Em Butroto, a Eneida reencontra os Retornos

III.3.1.7 - Morte de Anquises

III.3.2 - Canto IV

147

III.3.3 - O canto V

148

III.3.4 - O canto VI 151

Conclusão do capítulo 152

Conclusão 154

Bibliografia 


\title{
Resumo
}

Intitulada "As Pinturas do Templo de Juno e o Ciclo Troiano: imagem e memória épica na arquitetura da Eneida", esta tese aborda relações entre essa obra e o ciclo troiano a partir do episódio das pinturas do templo de Juno (I, v. 450-493). Na vastíssima bibliografia de estudos virgilianos, tal questão ocupa ainda pouco espaço. A fim de fundamentar a investigação dessas relações, efetua-se no capítulo inicial uma análise e uma reconstituição dos poemas perdidos desse ciclo (Cantos Cíprios, Etíope, Pequena Ilíada, Saque de Ílion, Retornos e Telegonia). Recorrendo-se ao capitulo I, demonstram-se quatro proposições nos capítulos II e III: as imagens desse templo evocam em especial epopéias do ciclo troiano (cap. II.1); as imagens encontram-se ordenadas conforme essa evocação (cap. II.2); na composição desse episódio, emprega-se e encena-se a teoria retórica da arte da memória (cap. II.3); a sequiência de épicos cíclicos evocados tem continuidade nos seis cantos iniciais e desse modo participa da arquitetura da Eneida (cap. III). As investigações realizadas para demonstrar essas proposições revelam um diálogo conscientemente urdido com poemas desse ciclo e assim propiciam a concretização de novos sentidos na leitura da Eneida. Com tal procedimento, Virgílio não apenas reaviva a memória da saga de Tróia, na qual insere sua epopéia, mas também "reedita" o ciclo troiano em função de Enéias.

Palavras-chave: Eneida, ciclo troiano, imagem, arquitetura, arte da memória.

\begin{abstract}
Entitled "The Pictures of Juno's Temple and the Trojan Cycle: image and epic memory in the architecture of the Aeneid", this dissertation focus on the relations between this literary piece of work and the Trojan cycle inspired in the episode of the paintings of Juno's temple (I, v. 450-493). Despite the extensive bibliography about the Virgilian studies, this issue has not been given appropriate attention throughout the years. In order to lay the foundations of these relations, the first chapter of this study presents an analysis and a reconstitution of the Trojan cycle lost poems (Cypria, Aethiopis, Little Iliad, Sack of Ilion, Returns and Telegony). The second and third chapters deal with four propositions: the pictures of Juno's temple specially evoke some poems from the Trojan cycle (cap. II.1); the images are disposed in conformity with this evocation (chapter II.2); in the composition of this episode, rhetoric theory of the art of memory is used and illustrated (chapter II.3); the sequence of evoked cyclic poems is continued in the first six books and being so plays some important role in the architecture of the Aeneid (chapter III). The investigations developed to demonstrate these propositions have revealed a dialogue consciously woven with the poems of this cycle and, therefore, propitiate the conveyance of new meanings in the reading of the Aeneid. With such proceeding Virgil not only revive the memory of the saga of Troy, in which his epic is contextualized, but he also "reedit" the Trojan cycle, this time, revolving around Aeneas.
\end{abstract}

keywords: Aeneid, Trojan cycle, image, architecture, art of memory.

\section{E-mail: ediletras@ufc.br}


in trod ução

Sic ait et animum pictura pascit inani

(En, I, v. 464)

Virgílio sempre nos abre a porta de sua casa, mas o interior, assim como Enéias entrando em Cartago, permanece envolto em névoa, através da qual há muito e a custo se tenta discernir a forma e a disposição dos móveis, objetos mais caros ao poeta... Outra vez penetramos nessa casa, intentamos agora compreender certas pinturas nas paredes de seu recinto épico.

Tais pinturas ornamentam o templo dedicado à deusa Juno em Cartago (I, v. 450-493) e constituem o ponto a partir do qual esta tese irradia-se; ao observá-las, percebemos alusões a épicos gregos, um princípio de organização e reflexos sobre a arquitetura do poema.

Percorramos um breve caminho até a definição dos contornos precisos desta investigação.

Seguindo a lição do in medias res, o canto inicial da Eneida nos arrebata ao centro dos acontecimentos. A epopéia começa com uma frota em alto mar, vinte barcos transportando troianos que deixaram para trás sua cidade em chamas, destruída por gregos após dez anos de batalhas, e seguem em busca de uma região onde possam reerguê-la. Uma tempestade os castiga próximo aos litorais da Líbia, norte da África; o mais seguro é aportar em praias próximas, desconhecidas. Os navios se espalham; sete descobrem uma baía, onde podem se refugiar... Enéias está em um deles. Esse guerreiro, agora responsável pelos sobreviventes, na manhã seguinte decide explorar a região, acompanhado do amigo Acates. No percurso se deparam com a deusa Vênus, disfarçada de caçadora, que lhes explica estarem em reinos púnicos, onde uma rainha tíria, Dido, erige uma cidade, Cartago. Depois desse encontro, prosseguem protegidos pela divindade, envoltos em uma névoa; invisíveis, percorrem a cidade e penetram em um bosque, no qual se ergue um templo à deusa Juno. Entram... e se surpreendem: nas paredes do templo, pinturas da guerra de Tróia, cuja fama chegou até ali e instigou artistas a tornar tal tema o objeto de sua arte. Uma a uma, Enéias as contempla e muito se emociona. Em seguida aparecem a rainha e os troianos dos outros barcos, que Enéias 
julgava perdidos. A rainha os acolhe e, na noite desse dia, oferece um banquete a seus caros hóspedes. Manjares e vinho, Juno e Baco, e uma canção entoada pelo aedo Iopas, ao som de uma cítara. Bebendo vinho e amor, Dido alonga a noite inquirindo Enéias sobre heróis e fatos da guerra e, ao fim do canto, pede-lhe que a todos relate as insídias dos dânaos, a queda dos seres caros a ele e o errar que há sete anos empreende por terra e mar... até chegar a Cartago.

As idéias geradoras deste estudo brotaram em meio a esse banquete, nos sulcos dos últimos versos desse canto, nos quais a rainha demonstra grande interesse pelas lembranças do herói troiano (v. 748-756).

Examinando a transição entre os cantos da Eneida, Harrison (1980) apresenta uma interessante análise desses versos. Inicialmente, destaca o vocábulo sermone (I, v. 748), considerando-o "the key term" (p. 360), indício de que Dido e Enéias mantêm uma conversa em particular a respeito de pontos diversos (uario, v. 748) da guerra de Tróia; as perguntas que lança ao troiano seriam indicadas "de forma breve e indireta" (p. 360-361) nos versos 750, 751 e 752; as respostas dele, entretanto, ficariam inteiramente a cargo da imaginação do receptor. De repente, o texto nos faz ouvir a voz da rainha; a partir desse momento, não mais estaria falando apenas para Enéias, mas em voz alta, para toda a audiência, solicitando que a todos (nobis, v. 753) o herói contasse episódios da guerra e da viagem até seu reino. E então se ouve a resposta: os cantos II e III.

Abordemos a mesma passagem por um ângulo um pouco diferente. Na conversa particular entre Dido e Enéias, não há uma ordem nos fatos comentados, na verdade a rainha indaga a respeito de personagens específicas: rogitans... super Priamo, super Hectore (v. 750), quibus Aurorae uenisset filius armis (v. 751), quales Diomedis equi, quantus Achilles (v. 752). Com sua apaixonada curiosidade, leva o herói a compor-lhe quadros diversos (uario) da guerra de Tróia... Quadros como aqueles pintados no templo de Juno. Aliás, as personagens elencadas nesse trecho soam bastante familiares, isso porque todas também aparecem no templo. E as respostas dele não ficariam inteiramente a cargo da imaginação do receptor: nesse instante, incitado por esse processo evocativo, o receptor seria remetido às pinturas e delas receberia elementos para concretizar o conteúdo da conversa mantida entre Dido e Enéias.

Depois de explorar lembranças de Enéias de forma desordenada e em particular, a rainha ergue a voz à audiência e o exorta a organizá-las cronologicamente (a prima origine, v. 
753) e emitir a todos um relato da guerra. A narrativa resultante ocupa os cantos II e III. São os cantos da memória: após um início in medias res, com os troianos chegando a Cartago, a epopéia resgata episódios anteriores através de lembranças de Enéias. Apesar de transcorridos sete anos de tantas aventuras desde o fim da guerra, tais lembranças estão bem vivas, pois há pouco foram revolvidas diante das pinturas do templo de Juno.

Destarte, nesse trecho final do canto primeiro, o horizonte de significação dessas pinturas seria redimensionado. Além de constituir uma ekphrasis e de aludir a outros poemas, estabelecendo um diálogo metapoético, seriam evocadas para desempenhar duas outras funções: a primeira, como vimos, consistiria em fornecer ao receptor elementos para concretizar a conversa particular mantida entre Dido e Enéias; a segunda, em realimentar a memória de Enéias a fim de que possa compor o relato solicitado pela rainha, selecionando e ordenando eventos remotos como se os tivesse vivido há poucos instantes.

Com essa análise, configura-se uma interessante combinação de elementos: imagens, memória, seleção e ordem de assuntos... composição de um texto. Tal conjuntura nos conduz ao universo da retórica, mais precisamente à seção denominada memória.

Para compor os cantos da memória, seria muito natural que Virgílio recorresse a essa seção da retórica. Essa hipótese inspira algumas questões. Ao vermos Enéias diante das pinturas do templo de Juno, estaríamos presenciando um exercício mnemônico de um orador diante de representações ordenadas de assuntos constituintes de um discurso? Servindo-se da retórica como fonte de recursos para a composição poética, Virgílio estaria também empregando e ao mesmo tempo encenando a teoria da arte da memória?

Essas perguntas norteiam nossa investigação. Que memória tais imagens evocam? Qual seu princípio de ordenação?

No que tange a fontes dos episódios representados nas pinturas, estudiosos ${ }^{1}$ têm reconhecido notadamente alusões a poemas pertencentes a um dos ciclos da antiga poesia épica grega, o troiano, composto pelas epopéias que abordam todo o desenrolar das Iliacas pugnas na seguinte ordem cronológica: Cantos Cíprios, Ilíada, Etíope, Pequena Ilíada, Saque de Ílion, Retornos, Odisséia e Telegonia - dessas, infelizmente, apenas a Ilíada e a Odisséia conservaram-se. Quanto à ordenação das pinturas, a própria Eneida indicia a existência de um

\footnotetext{
${ }^{1}$ Estudiosos do episódio das pinturas do templo de Juno são apresentados na introdução do capítulo II.
} 
princípio: uidet Iliacas ex ordine pugnas (I, v. 456). E a busca desse princípio tem instigado muitos estudos e arranjos interessantes (mas ainda insatisfatórios).

Com base nessas alusões e nesse indício, "limitamos" nosso estudo a um diálogo entre a Eneida e poemas do ciclo troiano ensejado pelas pinturas do templo de Juno. Desse diálogo depreendemos os quatro pressupostos que traçam as trilhas desta investigação:

1. as imagens do templo de Juno evocam em especial epopéias do ciclo troiano e com elas resgatam uma memória épica na qual a Eneida se insere;

2. nessa evocação reside o princípio de organização das imagens, capaz de justificar a expressão ex ordine;

3. nesse episódio, Virgílio emprega e põe em cena a teoria retórica da arte da memória;

4. a disposição dessas imagens participa da arquitetura dos seis cantos iniciais do poema.

Comprovar tais pressupostos é, pois, o objetivo deste trabalho. E em função desse propósito, foram concebidos o plano e a metodologia de desenvolvimento da tese:

- Introdução

- Capítulo primeiro

Realiza-se um estudo e uma reconstituição dos épicos perdidos do ciclo troiano, edificando um referencial para as análises efetuadas nos capítulos seguintes.

- Capítulo segundo

$\mathrm{Na}$ primeira parte, examina-se a relação entre as pinturas do templo de Juno e epopéias do ciclo troiano; em outras palavras, que poema cada imagem evoca.

Na segunda, esquadrinha-se a ordenação das imagens em função das alusões feitas a poemas do ciclo troiano, na ânsia de justificar o uso da expressão ex ordine.

$\mathrm{Na}$ terceira, demonstra-se o emprego da arte da memória no episódio das pinturas do templo de Juno.

- Capítulo terceiro

Analisa-se a participação dessas pinturas na arquitetura da Eneida mediante o exame do papel estrutural dos épicos do ciclo troiano nos seis cantos iniciais do poema.

- Conclusão 


\section{- Bibliografia}

As reflexões aqui desenvolvidas e os pressupostos apresentados já dão a entender a grande relevância do episódio das pinturas do templo de Juno para a Eneida. Isso nos oferece a oportunidade de comentar a epígrafe desta introdução. Nesse verso, a expressão pictura inani normalmente é traduzida por "vã pintura". Cabe então a pergunta: seriam mesmo vãs essas imagens?. Aparentemente não. Ao longo das páginas deste trabalho, há de se desvelar uma lauta carga de sentidos armazenados nesse episódio e dele decorrentes.

Apesar de ser bastante abordado pelos estudiosos da obra de Virgílio, esse episódio ainda não recebeu uma análise mais profunda de sua significação para o poema. Além disso, suas relações com o ciclo troiano são muito pouco estudadas.

Caberiam agora um exame do estado da questão e um comentário de obras de referência para os assuntos desta tese, mas não o faremos aqui. $\mathrm{Na}$ verdade, lidamos com "questões": o ciclo troiano, a relação entre esse ciclo e a Eneida, o episódio das pinturas e a arquitetura desse épico. Em razão dessa pluralidade de assuntos, decidimos examinar o estado de cada questão e sua respectiva bibliografia de referência no começo do capítulo correspondente.

Expliquemos neste momento algumas escolhas metodológicas.

No tocante às citações, apenas as destacadas do texto principal vêm traduzidas; o significado das demais normalmente se depreende do contexto. As traduções são em geral nossas; quando recorrermos a um texto alheio, indicaremos a fonte. As citações da Eneida provêm da edição de Jacques Perret para a editora "Les Belles Lettres"; quando as traduzimos, optamos por um texto em verso, buscando verter os hexâmetros de Virgílio em dodecassílabos. Em algumas citações, aparecem termos em negrito; são grifos nossos e têm por objetivo destacar elementos importantes para a análise.

Para as referências de obras citadas, usamos o sistema autor/data tanto no texto principal quanto nas notas de rodapé, sempre remetendo à bibliografia no final do trabalho. Esse procedimento faz exceção às edições de comentários de poemas, as quais são

\footnotetext{
${ }^{2}$ A tradução de "pictura inani" por "vã pintura" ou "vãs pinturas" ocorre, por exemplo, em todas as edições da Eneida presentes na bibliografia desta tese. Esse verso e sua tradução são apreciados no segundo capítulo (II.1.1).
} 
identificadas pelo sistema autor-canto-verso - e tais edições ocupam um lugar destacado na bibliografia.

Enfim, uma palavra sobre o método investigativo. Nesta leitura da Eneida, empregamos certos procedimentos e expressões terminológicas da teoria do efeito estético, de Wolfgang Iser. Em acordo com esse autor, acreditamos que uma obra de arte literária possui uma estrutura de comunicação voltada para seu receptor: através de indícios, ela até certo ponto orienta a leitura, sugere ao receptor suas veredas. Sob esse prisma, a maior ou menor concretização de sentidos e efeitos estéticos no ato da leitura de um texto depende de uma maior ou menor complexidade de sua estrutura comunicativa e do horizonte de expectativa do receptor, ou seja, de seu universo de conhecimento, o qual lhe possibilitará interagir com alguns ou com muitos indícios fornecidos pelo texto.

Esperamos concretizar sentidos úteis aos estudos virgilianos na leitura que segue. 
capítulo primeiro

\section{Os poemas perdidos do ciclo troiano}

O desenvolvimento da antiga poesia épica grega forjou a constituição de ciclos temáticos. Dois desses ciclos encontram-se bem configurados, o tebano e o troiano, cujos poemas desenrolam os episódios das duas maiores guerras da mitologia grega; e se discute a possível existência de um ciclo coríntio, formado por épicos ligados à cidade de Corinto e transmitidos sob a autoria do poeta Eumelo $^{3}$.

Neste capítulo, realiza-se uma reconstituição e um estudo das epopéias perdidas do ciclo troiano: Cantos Cíprios, Etíope, Pequena Ilíada, Saque de Ílion, Retornos e Telegonia. A investigação desse ciclo não representa o objetivo maior desta tese, sua função "limita-se" aqui ao edificar de um referencial profícuo para as discussões suscitadas nos capítulos seguintes. Destarte, não se tem a pretensão de compulsar minuciosamente o assunto - para a consulta de trabalhos mais detalhados sobre os ciclos épicos gregos, remete-se às obras citadas ao longo deste capítulo.

\footnotetext{
${ }^{3}$ WEST, 2002.
} 


\section{O ciclo troiano}

$\mathrm{O}$ século XIX e o princípio do XX testemunharam um germinar de significativos estudos do ciclo troiano, como o de F. G. Welcker, no livro Der Epische Kyklus, oder die homerischen Dichter (em dois volumes: o I em 1835 e o II em 1849), o de WilamowitzMöellendorff, no livro Homerische Untersuchungen (1884), o de A. Rzach, no artigo Kyklus (1922), o de D. B. Monro, no artigo "The Poems of the Epic Cycle" (1884) e no livro Homer's Odyssey, Books XIII-XXIV (1901, capítulo "Homer and the Epics Poets”), o de T. W. Allen, no artigo "The Epic Cycle" (1908) e no livro Homer. The Origins and the Transmission (1924), o de E. Bethe, no livro Homer. Dichtung und Sage, vol. II (1922) e III (1927), e o de A. Severyns, no livro Le Cycle Épique dans l'École d'Aristarque (1928b). Essas investigações derivaram, em grande parte, do perscrutar dos poemas homéricos, constituindo uma espécie de apêndice necessário a uma melhor compreensão da Ilíada e da Odisséia; nesse contexto, conformam, até certo ponto, frutos indiretos do fascínio que a "descoberta" da originalidade da mente e da literatura gregas despertava em pesquisadores (sobretudo germânicos) no século XVIII.

Desde então, o ciclo troiano atrai a atenção de estudiosos de diferentes áreas do conhecimento: pesquisadores da literatura, da história, da arqueologia, das artes figurativas... publicam cada vez mais trabalhos dedicados a esse ciclo, especialmente artigos. Dessa massa de pesquisas, destacam-se algumas de mais fôlego: a de F. Jouan (1966), a de G. H. Huxley (1969), as de M. Davies (1986 e 1989a), as de N. M. Horsfall (1979a, 1979b, 1983), a de Anderson (1997), as de Martin West (2000, 2002, 2003c), a de J. S. Burgess (2001) e a de A. Debiasi (2004).

Esse interesse favorece a elaboração de edições de testemunhos e fragmentos das epopéias perdidas: cedo surgiram as edições de Kinkel (1877), T. W. Allen (1912), EvelynWhite (1914) e E. Bethe (1922, reeditada em 1966); mais recentemente, as de A. Bernabé (1987), M. Davies (1988) e Martin West (2003a) ${ }^{4}$.

Em meio às diversas fontes de testemunhos e fragmentos, dois textos merecem um comentário prévio: a Biblioteca de Apolodoro e os sumários de Proclus.

A Biblioteca de Apolodoro constitui um manual de mitologia contendo histórias ligadas à guerra de Tróia. Sua datação é incerta: seguindo uma atribuição feita por Photius

\footnotetext{
${ }^{4}$ Essa edição substitui a de Evelyn-White na coleção Loeb.
} 
(c.820-893), pensou-se durante muito tempo que Apolodoro fosse um gramático ateniense do século II a.C., discípulo de Aristarco de Samotrácia (220-143 a. C.); hoje, no entanto, contesta-se essa identificação e acredita-se que o autor dessa Biblioteca tenha vivido entre os séculos I e II de nossa era ${ }^{5}$. Tal obra compõe-se de três livros e de um Epítome, com a seguinte distribuição de conteúdo: o Livro I compreende uma teogonia, a estirpe de Deucalião e as aventuras dos argonautas; o II, a estirpe de Ínaco, os doze trabalhos de Hércules, outras façanhas e a morte do herói e a história dos Heraclidas; o III, a estirpe de Agenor, a saga dos sete contra Tebas, a estirpe de Pelasgo, a de Atlante, a de Asopo e os reis de Atenas; o Epítome abrange as façanhas de Teseu, a estirpe de Tântalo, a guerra de Tróia, os retornos e as viagens de Odisseu. Até o século XIX, as edições da Biblioteca encerravam apenas os livros I, II e III, interrompendo-se bruscamente em meio às façanhas de Teseu; os textos do Epítome provêm de dois manuscritos descobertos no final do século XIX, o Codex Vaticanus 950 e o Codex Sabbaiticus ${ }^{6}$. Ainda que haja dúvidas quanto à atribuição desses epítomes ao Apolodoro autor da Biblioteca, eles aparecem nessa obra desde a edição publicada por R. Wagner em 1894, que serve de base para as posteriores ${ }^{7}$. No caso desta investigação, o interesse maior reside no Epítome, especialmente nas passagens referentes à guerra de Tróia (3-5).

No que tange aos sumários de Proclus (autor de origem e período de vida incertos ${ }^{8}$ ), trata-se de textos de uma obra (perdida) intitulada Chrestomathia. De acordo com Severyns (1928b, p. 245), essa obra seria uma ampla história da literatura grega, da qual os sumários dos poemas do ciclo troiano representariam apenas uma parte do capítulo consagrado à epopéia. "Fichamentos" desses textos surgiram inicialmente em uma obra do século IX também intitulada Biblioteca, do mesmo Photius citado há pouco. Mais tarde, extratos dos sumários originais relativos à gesta troiana foram descobertos em manuscritos da Ilíada: textos referentes aos Cantos Cíprios irromperam em diversos manuscritos; porém textos

\footnotetext{
${ }^{5}$ Cf. GUIDORIZZI, 1995, in: APOLLODORO. Biblioteca, p. XLIV.

${ }^{6}$ Para maiores detalhes sobre essas descobertas e os manuscritos usados para o estabelecimento do texto da Biblioteca, ver a edição de Frazer (APOLLODORUS. The Library, 1921, p. xxxiii-xliii).

${ }^{7}$ As referências à Biblioteca de Apolodoro serão doravante indicadas apenas com autor e localização na obra.

8 Duas possibilidades sobressaem a respeito da identidade de Proclus: poderia ser o filósofo neoplatônico falecido em 485 ou um gramático da época Antonina.
} 
referentes aos demais poemas dessa gesta acharam-se apenas no Venetus A (codex de Villoison ${ }^{9}$ ), dos séculos X/XI.

Embora forneçam dados importantes acerca de poemas perdidos, durante muito tempo houve certo descrédito em relação a esses sumários, principalmente em razão do desconhecimento da identidade de Proclus e de discordâncias entre eles e alguns testemunhos e fragmentos das epopéias; somente após a publicação do Epítome da Biblioteca de Apolodoro no final do século XIX, os sumários passaram a ser mais valorizados, dada a coincidência entre seu conteúdo e o do Epítome no tocante às histórias da guerra de Tróia.

A descoberta do Epítome proporcionou mais autoridade aos sumários de Proclus, entretanto não conseguiu dirimir os problemas concernentes às referidas discordâncias. Por isso, discute-se ainda se Proclus teria adaptado os épicos para evitar repetições e incoerências. A esse respeito, Severyns (1928b, p. 245) admite que essas supostas alterações não tenham sido da lavra de Proclus, mas de um gramático qualquer que viveu entre os séculos II e IX: esse desconhecido teria tido a idéia de extrair da obra de Proclus os sumários do ciclo troiano para usá-los como "prefácio" à leitura dos poemas homéricos. Como exemplo, cita o codex Venetus A, que traz os resumos copiados antes do texto da Ilíada. Essa nova função outorgada aos sumários teria então incitado modificações de seu conteúdo com o objetivo de melhor adaptá-los aos poemas homéricos ${ }^{10}$.

A reconstituição do conteúdo das epopéias perdidas proposta a seguir alicerça-se nas edições de testemunhos e fragmentos de Davies (1988) e West (2003a): a escolha da primeira deve-se ao fato de o autor conjugar aos textos dessa edição comentários tecidos em seu livro The Epic Cycle (1989a); a segunda foi escolhida por ser a mais atualizada, tendo colhido frutos de estudos mais recentes sobre o assunto $^{11}$. Além dessas edições, outras fontes participam eventualmente desta elaboração.

\footnotetext{
${ }^{9}$ Jean-Baptiste Gaspard de Villoison (1750/1753-1805), descobridor do manuscrito.

${ }^{10}$ Sem discutir quem atrelou os sumários aos manuscritos da Ilíada, Davies (1989, p. 7-8) também acredita que essa nova função tenha sido a responsável pelas discrepâncias entre os textos de Proclus e os fragmentos dos épicos.

${ }^{11}$ No texto, os testemunhos e fragmentos provenientes da edição de Davies são indicados respectivamente com as abreviações "test. D" e "fr. D"; os da edição de West, com "test. W" e "fr. W".
} 
Respeitando as fontes, o conteúdo dos poemas é reconstituído de forma mais linear e é destacado $^{12}$ do texto teórico; tenta-se com isso recuperar, até onde for possível, o sabor de uma narrativa inteiriça. Os sumários de Proclus funcionam como espinha dorsal da reconstituição, à qual são acrescentadas passagens fundamentadas nos testemunhos, nos fragmentos e, quando coerente, na Biblioteca de Apolodoro ${ }^{13}$; variantes significativas acompanham os episódios dos poemas. Quanto às muitas hipóteses e discussões dos estudiosos, apresenta-se uma triagem que tenciona esboçar bem o estado da questão e valorizar aspectos mais relevantes para os propósitos desta tese.

\footnotetext{
${ }^{12}$ Em itálico, fonte 10 e com um recuo à direita.

${ }^{13}$ Para a eventual combinação do conteúdo exposto por Proclus com o exposto por Apolodoro, segue-se a edição de West.
} 


\section{Cantos Cíprios}

O curioso título dessa epopéia $(K v i \pi \rho \alpha)$ encontraria justificativas em sua atribuição ao cipriota Stasino e no papel proeminente de Afrodite, deusa venerada em Chipre. Sua autoria recaía também sobre Homero ${ }^{14}$; Heródoto (História, II, 116-117) confirma essa imputação ao argumentar contra a possibilidade de Homero ser o autor dessa obra. Quanto à datação, recorrendo a características lingüísticas perceptíveis nos fragmentos, traços de uma língua mais recente que a dos poemas homéricos, West (2003a, p. 13) julga que essa epopéia dificilmente seria anterior à segunda metade do século VI a.C. Para Jouan (1966, p. 24-27, e n. 3 da p. 27), que se fundamenta de modo especial em representações figuradas de supostos episódios do poema, ela seria anterior a 650 a.C., composta provavelmente entre 680 e 660.

A efabulação dos Cantos Cíprios abarcaria eventos da guerra de Tróia anteriores aos da Ilíada, os quais estariam divididos em 11 livros segundo Proclus. De acordo com um escólio ao verso 5 do canto I da Ilíada ${ }^{15}$, tudo partiria de um plano de Zeus para diminuir a população da Terra, a qual, sofrendo com o peso e com a impiedade dos homens, teria solicitado ao deus uma diminuição desse fardo. Em resposta, Zeus reduziria a humanidade provocando duas guerras: inicialmente a de Tebas, a de Tróia em seguida. Momo (uma personificação da "argúcia", do "sarcasmo") seria o idealizador dessa segunda contenda e de dois estratagemas para executá-la: o casamento de Tétis com um mortal e a geração de uma belíssima filha de Zeus. Tais fatos causariam mais tarde a guerra de Tróia ${ }^{16}$. Todavia, os versos do fragmento em si, apenso ao comentário do escoliasta, relatam apenas a sobrecarga da terra, o apiedar-se de Zeus diante das circunstâncias e a resolução de aliviar esse fardo através da guerra de Tróia, na qual muitos guerreiros morreriam. A última frase do fragmento

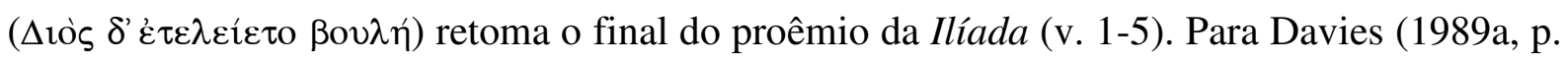
34), essa frase na Ilíada diria respeito apenas à ação resultante da ira de Aquiles, o enviar de várias almas ao Hades. Essa leitura mais evidente corresponde às dos gramáticos alexandrinos Aristófanes de Bizâncio (260-181 a. C.) e Aristarco de Samotrácia (220-144 a. C.), que procuravam explicar os poemas homéricos sem recorrer a textos dos poetas cíclicos. De fato, na abertura do escólio, figura a seguinte lição de Aristarco: unir sem pontuação o verso 5 ao 6

\footnotetext{
${ }^{14}$ Test. D e W.

${ }^{15}$ Escólio (DINDORFIUS) à Ilíada, I, v. 5-6 = fr. 1 D e W.

${ }^{16}$ Esse mito também freqüenta duas obras atribuídas a Hesíodo: Os Trabalhos e os Dias (v. 156-173) e Catálogo de Mulheres (fr. 96, 56-91 e 68 Evelyn-White).
} 
do canto I da Ilíada; a leitura decorrente tornaria o plano de Zeus uma contingência da guerra de Tróia oriunda do pedido de Tétis, e não de uma razão anterior ao conflito.

O contexto desse fragmento é muito significativo para o poema, e diante dele surge a primeira dúvida: além de tratar do fardo imposto à Terra pela grande quantidade de homens, os Cantos Cíprios abordariam a impiedade humana, as guerras tebanas, o conselho de Momo para desencadear a guerra de Tróia?

No livro Euripide et les Chants Cypriens, Jouan dedica um capítulo ("La volonté de Zeus") a tal questão. Depois de examinar argumentos alheios e refletir sobre o assunto, avalia mais verossímil a hipótese segundo a qual todos esses temas apareceriam ao menos no prólogo desse épico (p. 47-48) - pode-se acrescentar outro elemento a favor dessa hipótese: uma vez que episódios das guerras tebanas são relatados em uma digressão forjada por Nestor, tais guerras poderiam já integrar o prólogo dos Cantos Cíprios. Pleiteando a participação desse conselheiro de Zeus na epopéia, Jouan (p. 46) cita um drama satírico (perdido) de Sófocles intitulado Momos, que se ligaria às peças Éris, sobre a querela entre as deusas, e Crísis, sobre o julgamento de Páris ${ }^{17}$; apoiando-se nisso, argumenta que essas três peças deveriam extrair assuntos dos Cantos Cíprios; depois relembra Momo ser irmão de Nêmesis (a mãe de Helena nessa versão) e de Éris, a entidade deflagradora da discórdia entre as deusas ${ }^{18}$; em consequiência, julga plausível que os três irmãos desempenhassem um papel relevante na implementação do plano de Zeus.

Embora haja dúvidas quanto à participação de Momo, suas sugestões para a deflagração da guerra de Tróia realmente se concretizam.

Avesso ao pensamento de Jouan, Davies (1989a, p. 35) estima improvável que os eventos presentes no comentário do escoliasta fizessem parte do poema, pois os considera incompatíveis com o fragmento em si.

Apesar das controvérsias, essas reflexões em torno do primeiro fragmento dão a entender que o plano de Zeus deveria funcionar como fio condutor da trama dos Cantos Cíprios, que se desenrola como segue.

Zeus delibera com Têmis a respeito da guerra de Tróia, de seu plano. Com a finalidade de gerar uma linda filha, Zeus persegue Nêmesis, a qual tenta escapar

\footnotetext{
${ }_{17}^{17}$ Para as peças, ver a edição de Radt (1977: Éris, fr. 199-201; Crísis, fr. 360-361; Momos, fr. 419-424).

${ }^{18}$ As três entidades são filhas da Noite (HESÍODO, Teogonia, v. 214 e 225, Os Trabalhos e os Dias, v. 11-41).
} 
fugindo através das terras e das águas, escondendo-se em meio à escuridão, mudando de forma: em peixe entre as ondas do mar, em criaturas assombrosas criadas pela Terra... Contudo, quando assume o feitio de um ganso, Zeus, sob o feitio de um cisne, une-se a ela. Dessa união, ela concebe um ovo e o abandona entre árvores. Um pastor o encontra e o leva para Leda, esposa de Tíndaro, rei de Esparta. Com os cuidados de Leda, do ovo nasce a linda Helena, que a rainha adota como filha ${ }^{19}$.

Em outra versão, Leda é a mãe de Helena ${ }^{20}$. Segundo Severyns (1928b, p. 266-271), a variante que faz de Leda a mãe de Helena teria suplantado a mais antiga, com Nêmesis, sobretudo a partir do século IV a. C. Jouan (1966, p. 148), ao contrário, supõe que a variante adotada nos Cantos Cíprios seja a mais recente e resultante de um arranjo para melhor integrá-la ao plano de Zeus (Momo-Nêmesis-Éris) e estabelecer um paralelo entre a concepção de Helena e a de Aquiles; esse autor (p. 148, n. 5) ainda reproduz uma hipótese segundo a qual as variantes refletiriam regionalismos: a versão com Helena nascida de Leda seria própria do Peloponeso; a com Helena nascida de Nêmesis, própria da Ática.

A outra parte do projeto tem curso com os episódios do casamento de Tétis e Peleu.

Para agradar Hera, Tétis rejeita o assédio de Zeus ${ }^{21}$. Zangado, o deus a obriga a casar-se com um mortal, Peleu ${ }^{22}$. Ciente de que Tétis resistirá a essa união, o centauro Quíron ensina a Peleu como capturá-la, como deve proceder enquanto ela se metamorfoseia em fogo, em água, em animal ${ }^{23}$... Ele precisa retê-la até que ela reassuma sua forma original ${ }^{24}$. Peleu assim o faz.

Conquistada a noiva, a festa do casamento acontece no Monte Pélio. Deuses, ninfas, graças chegam e trazem presentes: Quíron oferece uma lança ao recém-casado, engendrada por Atena e confeccionada por Hefesto, com a qual Peleu e depois Aquiles

\footnotetext{
${ }^{19}$ ATENEU, Deipnosophistae, 334 = fr. 7 D, fr. 10 W; FILODEMO, De Pietate B 7369 Obbink = fr. 8 D, fr. 11 $\mathrm{W}$.

${ }^{20}$ Como em Apolodoro (III, 10, 7) ou na Helena (v. 17-21), de Eurípides.

${ }^{21}$ De acordo com Huxley (1969, p. 140) e Debiasi (2004, p. 114-115 e 116, n. 36), desse episódio participaria

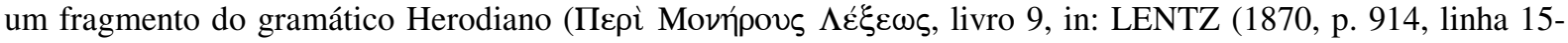
$19)=$ fr. $26 \mathrm{D}$, fr. $30 \mathrm{~W}$ ), o qual menciona as Górgonas, moradoras de Sarpedo, uma ilha de pedra em pleno oceano turbulento: fugindo de Zeus, Tétis ter-se-ia refugiado ao pé das Górgonas, suas primas - sendo o pai dela, Nereu, o irmão mais velho de Fórcis e Ceto, pais das Górgonas (HESÍODO, Teogonia, v. 233-239 e 270-276).

${ }^{22}$ FILODEMO, De Pietate B 7241 Obbink = fr. 2 D e W. Esta versão aparece ainda em Apolônio de Rodes (Argonáuticas, IV, v. 790-798) e em Apolodoro (III, 13, 5). Comparando esse relato com o comentário do escoliasta do fragmento 1, não se sabe se há divergência ou se o assédio e o rancor de Zeus consistem apenas em um artifício para pôr em prática o conselho de Momo.

${ }^{23}$ Tétis é assimilada a Nêmesis, e o nascimento de Aquiles ao de Helena.

${ }^{24}$ Escólio (MAASS) à Ilíada, XVIII, v. 434a; Apolodoro, III, 13, 5 = fr. 3 W. Em Píndaro (Neméias, 4, v. 62), ocorre a primeira aparição literária conhecida desse mito.
} 
hão de se impor nas batalhas; Posídon oferece os cavalos imortais Bálio e Xanto ${ }^{25}$... Então, para dar continuidade a seu plano, Zeus pede a Hermes que barre a entrada de Éris, a fim de que ela, por vingança, semeie a discórdia entre os convivas. Assim, em meio à cerimônia, eclode uma disputa entre as divindades: Atena, Hera e Afrodite concorrem quanto à beleza ${ }^{26}$. Atendendo a uma solicitação de Zeus, Hermes as conduz ao monte Ida, onde Alexandre fará o julgamento ${ }^{27}$.

No caminho, Afrodite prepara-se com zelo para seduzir o juiz: banha-se, veste uma roupa tecida pelas Graças e pelas Horas, tingida e perfumada de flores primaveris; em seguida, ela, Ninfas e Graças constroem guirlandas de flores e enfeitam as cabeças ${ }^{28}$. Após esse ritual, seguem para monte o Ida.

Uma vez diante de Alexandre, cada concorrente propõe-lhe uma recompensa em troca de uma sentença favorável: Hera, reinados; Atena, vitórias em guerras; Afrodite, o amor de Helena. Encantado com a possibilidade de sua união com Helena, Alexandre concede a vitória a Afrodite.

Com relação ao narrado até aqui, Jouan (1966, p. 48) desenvolve uma reflexão ousada (e talvez muito influenciada pela tragédia) a respeito do tratamento da impiedade humana no poema: os Cantos Cíprios trariam à tona a noção de julgamento moral, que não emergiria na Ilíada nem deveria fazer parte do mito antes da confecção desse épico. Por esse prisma, analisa o aspecto moral do plano de Zeus e a participação dos deuses em sua execução (p. 49): Éris cumpriria bem sua incumbência, enquanto Nêmesis resistiria, tentaria fazer face a esse desígnio de Zeus; e Afrodite, talvez inconscientemente, à guisa de instrumento, produziria o desencadear de tudo ${ }^{29}$; a partir desse ponto de vista, Aquiles e Helena não deveriam ser condenados individualmente por seus atos, visto serem manipulados pelos deuses; o poema deveria então julgar a impiedade humana de forma coletiva, isentando de culpa os heróis usados pelos deuses para a execução dos desígnios destes.

\footnotetext{
${ }^{25}$ Escólio (DINDORFIUS) à Ilíada, XVI, v. 140 = fr. 3 D, fr. 4 W.

${ }^{26}$ Davies (1989a, p. 36) comenta a possibilidade de não haver nesse épico o pomo da discórdia, que deveria ser uma invenção posterior, provavelmente alexandrina.

${ }^{27}$ Mencionado na Ilíada (XXIV, v. 25-30); estes versos, porém, são contestados por Aristarco, argumentando que Homero não faz referência ao julgamento das divindades (SEVERYNS, 1928b, p. 261-264).

${ }^{28}$ Segundo Ateneu (Deipnosophistae, 682d-f = Fr. 4 e 5 D, fr. 5 e 6 W), estaria no livro I do poema o ritual de preparação de Afrodite. Eurípides descreve esse ritual na peça Ifigênia em Áulis (v. 1294-1299).

${ }^{29}$ Esse papel dos deuses suscita uma interpretação alegórica: Momo, Éris, Nêmesis e Têmis... o sarcasmo, a discórdia, o castigo e a justiça. Pena não dispormos desse poema! A confecção de alegorias constitui, aliás, um traço bem característico da épica cíclica - o qual Virgílio explora.
} 
Os passos iniciais da realização do plano de Zeus e essa reflexão de Jouan põem Aquiles e Helena em evidência: o maior dos heróis e a mais bela das mortais seriam os instrumentos principais do desenvolvimento desse plano. Essa constatação auxilia a compreender melhor o teor e o encadeamento dos episódios da epopéia.

Eleita a mais bela das deusas, Afrodite cumpre sua promessa: sob suas instruções, os troianos constroem uma frota para Alexandre ${ }^{30}$. Heleno emite profecias a respeito da expedição que se prepara. Afrodite encarrega seu filho, Enéias, de acompanhar Alexandre. E Cassandra também revela o futuro da missão ${ }^{31}$.

Zarpam. Aportam inicialmente na Lacedemônia, onde são recebidos por Castor e Pólux; depois, em Esparta, onde são bem acolhidos por Menelau. Durante um banquete proporcionado pela família real aos troianos, Alexandre oferece presentes a Helena em agradecimento pela hospitalidade.

Em meio à visita, Menelau precisa partir para Creta, para os funerais de seu avô materno, Crateu ${ }^{32}$. Antes de viajar, o rei solicita a Helena que providencie tudo de que os hóspedes necessitem até que estes partam.

Com a ausência de Menelau, Afrodite provoca um encontro amoroso entre Helena e Alexandre. Consumada a união sob os auspícios da deusa, os amantes colocam parte do tesouro do palácio em um barco e vão-se à noite ${ }^{33}$. Na fuga, Helena abandona a filha, Hermíone, então com nove anos ${ }^{34}$.

Em alto mar, Hera provoca uma tempestade contra a frota de Alexandre, que é empurrada para Sídon, na Fenícia ${ }^{35}$. Saqueiam a cidade e depois rumam para Ílion. Ao chegarem, acontece a celebração do casamento de Alexandre e Helena.

Essa tempestade e a conseqüente digressão por Sídon, relatadas por Proclus e Apolodoro, são contestadas por um testemunho de Heródoto (História, II, 116-117) ${ }^{36}$, de

\footnotetext{
${ }^{30}$ Escólio (DINDORFIUS) à Ilíada, III, v. 443 = fr. 8 W. O canto V da Ilíada (v. 59-64) narra a morte do construtor da frota de Páris, Féreclo. E Apolodoro (Epítome, 3, 2) refere o mesmo construtor.

31 Segundo Aristarco (escólio (MAASS) à Ilíada, XXIV, v. 699), Cassandra não é profetisa nos poemas

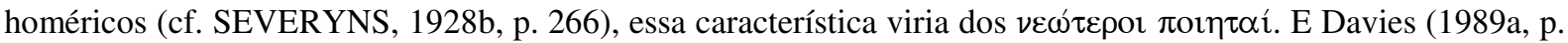
39-40) comenta o relevo que esse épico concede a oráculos e profecias, diferentemente do que acontece nos poemas homéricos. A peça perdida Alexandros (RADT, fr. 91a-99), de Eurípides, exporia tais profecias de Cassandra; em fragmentos da peça perdida Alexander (JOUAN; VAN LOOY, 1998, in: EURIPIDE, Tragédies, tome VIII, $I^{e}$ partie), de Ênio, modelada na de Eurípides, aparecem traços do provável conteúdo dessas profecias.

${ }^{32}$ Apolodoro (Epítome, 3, 3) conta que Páris ficou nove dias em Esparta em companhia de Menelau, que seguiu para Creta no décimo dia.

${ }^{33}$ Ilíada III, v. 70-72, 91-93, 281-287.

${ }^{34}$ APOLODORO, Epítome, 3, 3.

${ }^{35}$ Segundo Apolodoro (Epítome, 3, 4), a tempestade leva a frota de Páris a Sídon e a Chipre; precavendo-se contra uma possível perseguição, Páris demora-se algum tempo nesses locais.
} 
acordo com o qual a viagem de Páris de Esparta a Tróia nos Cantos Cíprios durava apenas três dias, graças a um vento favorável e a um mar calmo. A digressão, no entanto, figura na Ilíada (VI, v. 289-292). Ao abordarem esse episódio, Ésquilo (Agamêmnon, v.691-692) e Eurípides (Helena, v. 1117) insinuam uma viagem rápida. Desse modo, se houve alteração, deve ser posterior a Eurípides. Considerando a questão, Jouan (1966, p. 182, n. 1) e Burgess (2001, p. 19) levantam a possibilidade de se tratar de uma mudança posterior ao testemunho de Heródoto (talvez até mesmo incitada pela observação do historiador), concebida para estabelecer uma harmonia entre o relato dos Cantos Cíprios e o de Homero.

Após as núpcias, o poema retomaria a história dos Dióscuros.

Castor e Pólux são apanhados roubando as vacas de Idas e Linceu, filhos de Afareu, que é, por sua vez, irmão de Tíndaro. Procurando os ladrões, Linceu sobe no monte Taígeto para ver ao longe; com sua visão privilegiada, avista Castor escondido na cavidade de um carvalho ${ }^{37}$ e avisa o irmão. Idas então mata Castor ${ }^{38}$. Vingando o irmão, Pólux mata Idas e Linceu. E Zeus concede aos Dióscuros a imortalidade em dias alternados.

Pausânias (Descrição da Grécia, III, 16, 1) ${ }^{39}$ nos guia a outra aventura de Castor e Pólux provavelmente integrante dos Cantos Cíprios. Tratando de um santuário de Hilaíra e Febe, filhas de Leucipo, Pausânias informa que o autor desse épico afirmava que elas eram filhas de Apolo. A participação delas no poema evocaria outro conflito envolvendo os Dióscuros e os filhos de Afareu. Em Teócrito (XXII, 137-140) e Higino (Fáb., 80), encontramos Febe e Hilaíra prometidas a Idas e Linceu; apaixonados por elas, os Dióscuros as raptaram, provocando uma disputa na qual morrem Linceu, Idas e Castor ${ }^{40}$. Um escólio (DINDORFIUS) ao verso 243 do canto III da Ilíada conta que os Dióscuros foram convidados ao matrimônio dos primos Linceu e Idas e que o rapto ocorreu antes da consumação do casamento; em decorrência, uma luta explodiu entre os primos, na qual Idas, Linceu e Castor faleceram. Apolodoro (III, 11, 2) relata os dois conflitos, primeiramente o

\footnotetext{
${ }^{36}$ Fr. $11 \mathrm{D}$ e $14 \mathrm{~W}$.

${ }^{37}$ Escólio (DRACHMANN) à X Neméia (v. 114a) de Píndaro = Fr. 13 D, fr. 16 W.

${ }^{38}$ FILODEMO, De Pietate B 4833 Obbink = fr. 14 D, fr. 17 W.

${ }^{39}$ Fr. 9 D, fr. 15 W. Referências posteriores a Pausânias dizem respeito a essa obra e serão indicadas apenas com autor e localização no livro.

${ }^{40}$ Propércio (I, 2, v. 15-16) conta que Castor encantou-se por Febe, Pólux por Hilaíra; ver também em Ovídio (Metamorfoses, V, v. 600-720).
} 
rapto das noivas, depois o conflito envolvendo o roubo das vacas; este último seria a razão da luta mortal entre os primos - em acordo com Proclus, o qual expõe apenas o conflito causador das mortes. Talvez as duas querelas integrassem os Cantos Cíprios, na seqüência apresentada por Apolodoro; ignora-se, contudo, como se relacionavam exatamente. Enfim, cabe ressaltar que a morte dos irmãos nessa epopéia justificaria a ausência deles na guerra de Tróia e, sobretudo, na Ilíada, lamentada por Helena (III, v. 228-242) em meio ao célebre episódio no qual identifica alguns dos guerreiros gregos para Príamo.

Ainda sobre a participação de Castor e Pólux, ao comentar um texto de Clemente de Alexandria (Protrepticus, II, 30, 5) ${ }^{41}$, Severyns (1928b, p. 268-274) admite que o poema também abordaria o nascimento deles ${ }^{42}$ (anterior ao de Helena) e uma expedição empreendida contra Atenas, em decorrência do rapto de Helena por Teseu e Pirítoo: desejando uma filha de Zeus por esposa, raptam primeiramente Helena para Teseu e a conduzem a Atenas; depois, seguem ao Hades em busca de Perséfone para Pirítoo, mas antes deixam Helena na cidade ática de Afidna, sob a proteção do rei Afidno e aos cuidados da mãe de Teseu, Etra; enquanto Teseu e Pirítoo caçam esposas, os Dióscuros reúnem um exército e marcham para resgatar a irmã; nessa expedição, saqueiam Afidna, resgatam Helena e arrebatam Etra como cativa; na luta, Castor é ferido na coxa direita pelo rei Afidno; em seguida, não encontrando Teseu, pilham Atenas ${ }^{43}$.

Infelizmente, não se sabe se todas essas aventuras dos Dióscuros integravam os Cantos Cíprios nem como as que de fato a ele pertenciam funcionavam em sua trama. De qualquer forma, é estranho e ao mesmo tempo sugestivo o encadeamento exposto por Proclus: as aventuras de Castor e Pólux alternam-se com os acontecimentos do rapto de Helena. Que estratégia textual essa arquitetura traduziria?

\footnotetext{
${ }^{41}$ Fr. 6 D, fr. 9 W.

${ }^{42}$ Com a seguinte filiação: Castor, mortal, sendo filho de Tíndaro e Leda; Pólux, imortal, de Zeus e Leda.

${ }^{43}$ Escólio (DINDORFIUS) à Ilíada, III, v. 242 = fr. 12 D e W.
} 
Após o segundo episódio dos Dióscuros, Íris, mensageira dos deuses, vai a Menelau e lhe revela o que aconteceu na casa deste. O rei então segue para o palácio de Agamêmnon, em Micenas, onde deliberam sobre uma expedição contra Ílion. Depois, Menelau visita Nestor. $O$ velho o acolhe e lhe oferece vinho com as seguintes palavras:

"Vinho, Menelau, dos deuses o melhor feito aos mortais para aplacar os males." 44

E, tecendo uma digressão, Nestor lhe conta como Epopeu teve sua cidade, Sícion, inteiramente destruída após seduzir Antíope, a filha de Licurgo ${ }^{45}$; em seguida, narra a história de Édipo ${ }^{46}$, a loucura de Héracles e a história de Teseu e Ariadne ${ }^{47}$.

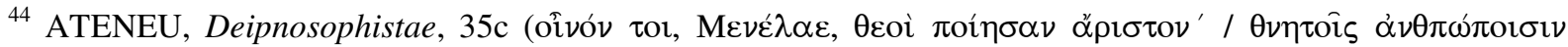
$\alpha \pi \mathrm{o} \sigma \kappa \varepsilon \delta \alpha \sigma \alpha \mathrm{l} \mu \varepsilon \lambda \varepsilon \delta \omega \dot{\nu} \alpha \varsigma)=$ Fr. $15 \mathrm{D}, 18 \mathrm{~W}$.

${ }^{45}$ Antíope aparece na Odisséia (XI, v. 260-265) em meio ao "catálogo de mulheres" vistas por Odisseu durante a nekyia; aqui é filha do rio Asopo e mãe de Zeto e Anfíon, filhos de Zeus e fundadores de Tebas. Essa passagem, contudo, é considerada parte de uma interpolação que se estenderia do verso 225 ao 626 (cf. o comentário de Bérard, in: HOMÈRE. L'Odyssée, tome II, p. 92, nota ao verso 225). Em um fragmento do poeta Ásios de Samos (séc. VI a.C., citado por Pausânias (II, 6, 4) = fr. 1 West (2003a, p. 254)), Antíope também é filha do rio Asopo, mas Zeto e Anfíon são agora concebidos por Zeus e Epopeu. Os escólios (DINDORFIUS) ao verso 260 do canto XI da Odisséia informam que os trágicos fazem dela a filha de Nicteu, irmão de Lico (que seria o mesmo Licurgo); de fato, na tragédia perdida Antíope, de Eurípides (JOUAN \& VAN LOOY, 1998, p. 213-274), ela é filha de Nicteu. Nas Argonáuticas, Apolônio de Rodes apresenta as duas versões: ela é filha de Asopo no canto I (v. 735-741) e de Nicteu no IV (v. 1090). Pacúvio segue Eurípides em sua Antiopa (Iouis ex Antiopa Nyctei nati <duo>, in: JOUAN \& VAN LOOY, 1998, p. 272). Em Higino (Fáb., 7 e 8, sendo esta última uma compilação das peças de Eurípides e Pacúvio), Antíope também é filha de Nicteu. Apolodoro (III, 5) e Propércio (III, 15) também dão Nicteu como pai de Antíope. Diante dessas abordagens da lenda de Antíope, a atribuição de Proclus afigura-se estranha; contudo, não é possível saber se isso constitui um equívoco ou se nos Cantos Cíprios Lico realmente aparecia como pai de Antíope. Apresentamos agora um resumo dos episódios dessa lenda para os quais há maior concordância. Antíope, famosa pela beleza, é possuída por Zeus; o pai descobre tudo e ameaça castigá-la; temerosa, foge; na fuga, arrebatada ou acolhida, acaba junto de Epopeu, em Sícion. Antes de morrer em conseqüência desse drama, Nicteu pede a Lico que resgate Antíope; Lico, novo governante de Tebas, invade Sícion, mata Epopeu e resgata Antíope. Durante o regresso, nas proximidades do Citéron ou mesmo sobre tal monte, ela dá à luz gêmeos, que são recolhidos por um pastor, o qual lhes põe os nomes de Zeto e Anfíon; mais tarde, ela foge dos castigos recebidos na casa de Lico e vaga perto do Citéron, é reconhecida pelo pastor, que revela a verdade a Zeto e Anfíon; estes então atacam Tebas e tomam o trono a Lico. Antíope deve ter partilhado o leito de Lico, o que também explica a raiva que a esposa deste, Dirce, nutre por ela; e Higino (Fáb., 7) chega mesmo a dar Antíope como esposa de Lico. Não se pode dizer de qual se trata e até onde se estende a versão que Nestor conta nos Cantos Cíprios; mesmo assim, Jouan (1966, p. 375) supõe os seguintes eventos nesse épico: Epopeu, rei de Sícion, durante uma visita a Lico, na Beócia, seduz a filha deste, Antíope, e a rapta; então Lico marcha contra Sícion, toma a cidade, mata Epopeu e leva Antíope de volta para casa, onde esta é castigada por sua culpa. Tal lenda pertence ao ciclo tebano, embora também não se possa dizer se integrava uma epopéia e qual seria. É possível ainda compreender o interesse que a lenda de Antíope despertou nos escritores latinos; com efeito, possui muitos pontos em comum com a de Réia Sílvia e dos gêmeos.

${ }^{46}$ Como a lenda de Antíope, a de Édipo evoca o ciclo tebano, diretamente os poemas Tebaída e Edipodia.

${ }^{47}$ Ariadne também aparece em meio ao "catálogo de mulheres" da Odisséia (XI, v. 321-325). Além de o todo ser considerado uma interpolação, Bérard (HOMÈRE. L'Odyssée, tome II, p. 96) fornece um argumento a mais para se desconfiar sessa passagem: tais versos citam o deus Dioniso, que não figura em nenhum outro lugar no poema. No escólio ao verso 322 (DINDORFIUS), conta-se a história de Teseu e Ariadne, atribuída a Ferecide (Severyns, 1928b, p. 281-283): Atena manda Teseu partir para Creta e abandonar Ariadne; Afrodite aparece para Ariadne e diz que ela esposará Dioniso; ela é morta por Ártemis por ter violado sua virgindade - Severyns (1928b, p. 283) acredita que essa seria a versão contada por Nestor nos Cantos Cíprios e (ibidem, n. 1,) supõe ainda que o abandono de Ariadne por outra mulher não faria parte da versão mais antiga dos $v \varepsilon \omega \tau \varepsilon \rho o$, seria um 
Essa digressão tem despertado o interesse de muitos estudiosos, que se perguntam qual seria o liame entre os fatos contados por Nestor e o enredo dos Cantos Cíprios, em particular no que diz respeito à situação de Menelau. Retomando a questão, Jouan (1966, p. 373-374) destaca inicialmente duas posições: para alguns, esse episódio não se relacionaria diretamente com o enredo do poema, refletiria apenas uma característica de Nestor já presente nos poemas homéricos, isto é, o gosto por contar histórias ${ }^{48}$; para outros, que procuram ver na seleção dos relatos de Nestor uma relação direta com a situação de Menelau, as histórias serviriam de exemplos reconfortantes para o rei de Esparta (é mais fácil entrever tal aspecto na primeira e na última lendas, que mostram raptos de jovens e consequiências negativas para os raptores) ${ }^{49}$. Recordando o emprego do mito como exemplo, Jouan (p. 374) estima que a segunda posição seja mais verossímil e que nessa digressão o poema também indicaria suas escolhas entre as variantes de cada uma das lendas.

Além desse aspecto, cabe salientar que a digressão de Nestor evoca os demais temas maiores da épica grega perdida: o ciclo tebano e os poemas independentes em torno de Héracles e Teseu. Estaria o autor dos Cantos Cíprios fazendo alusões diretas a poemas existentes ou apenas a mitos muito difundidos? Que função essa digressão desempenharia nessa epopéia? Seria interessante encontrar respostas a tais questões, especialmente porque o episódio de Nestor, sobretudo sua estratégia de composição, parece ter sido fecundo para poetas posteriores.

De volta ao enredo dos Cantos Cíprios...

Menelau e Nestor percorrem a Hélade em busca de aliados, reunindo os chefes. Agamêmnon também participa dessa missão enviando um arauto para cada rei, lembrando-lhes o juramento feito e que essa afronta afetava a casa de cada um deles ${ }^{50}$.

Tentando furtar-se à expedição, Odisseu finge insanidade. Todavia, a farsa é descoberta: Palamedes, filho de Náuplio, segue Odisseu; em determinada ocasião,

desenvolvimento posterior. Jouan (1966, p. 386) também crê que esse escólio represente a versão dos Cantos Cíprios, no entanto sem a frase que diz que Ariadne foi morta por Ártemis, pois seria estranho que a deusa matasse Ariadne estando esta sob a proteção e sob o amor intenso de Dioniso; isso seria uma retomada da versão exposta na nekyia da Odisséia. Mesmo eliminando a morte súbita de Ariadne, a razão de sua culpa poderia permanecer, ou seja, a quebra do voto de virgindade.

${ }_{48}$ Jouan (1966, p. 373, n. 3) enumera os principais partidários de tal posição.

${ }^{49}$ Jouan $(1966$, p. 374, n. 1) enumera os principais partidários de tal posição.

${ }^{50}$ APOLODORO, Epítome, $3,6$. 
arranca Telêmaco do seio de Penélope e saca a espada como se fosse matar a criança; para evitar a morte do filho, o pai confessa o ardil e aceita integrar a expedição ${ }^{51}$.

Tomando agora parte ativa no projeto, Odisseu viaja com Menelau e Taltíbio até o palácio de Cíniras, em Chipre, onde convencem o rei a apoiar a expedição. Cíniras promete em juramento fornecer cinqüenta barcos e sela seu compromisso enviando a Agamêmnon uma couraça de presente; no entanto, no momento de cumprir sua promessa, lança ao mar uma embarcação real, sob o comando do filho de Pigmalião ${ }^{52}$, e quarenta e nove feitas de argila ${ }^{53}$.

Findado o processo de convocação dos chefes gregos, os que aderem à empresa se reúnem em Áulis e realizam sacrifícios. Nesta ocasião, ocorre o prodígio da serpente e dos pássaros $^{54}$, a partir do qual o adivinho Calcante prediz o desenrolar da guerra vindoura.

A expedição tem início. Após algum tempo de viagem, aportam no litoral de Teutrânia, na Mísia. Pensando já se tratar de Ílion ${ }^{55}$, saqueiam a cidade.

Vendo seu reino atacado, Télefo, rei da Mísia e filho de Héracles, arma os mísios e persegue os gregos até os barcos, matando muitos, entre os quais Tersandro, filho de Polinice. Porém, enfrentado por Aquiles, Télefo resolve fugir; durante a fuga, fica preso em um galho de videira e é então ferido em uma coxa pela lança de Aquiles ${ }^{56}$.

Controlada a reação dos mísios, os gregos deixam a região. No mar, são surpreendidos por uma tempestade, que os dispersa. Na dispersão, Aquiles acaba aportando em Ciros, onde se casa com Deidâmia, filha de Licomedes.

Uma versão do escólio (DINDORFIUS) ao verso 59 do canto I da Ilíada (referido na última nota) - considerada por Severyns (1928b, p. 293) um verdadeiro resumo do episódio correspondente dos Cantos Cíprios - informa que os gregos teriam navegado rumo a Argos após a tempestade.

\footnotetext{
51 APOLODORO, Epítome, 3, 7.

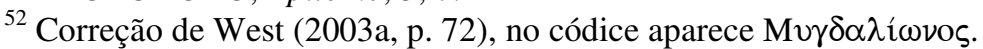

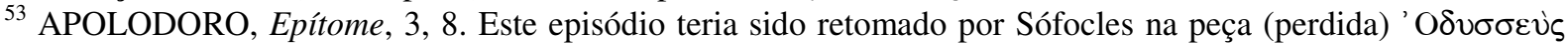

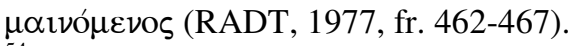

${ }_{55}^{54}$ Relatado por Odisseu na Ilíada (II, v. 303-332).

${ }_{55}$ Apolodoro (Epítome, 3,17 ) explica que os gregos não conheciam bem a rota para Tróia, daí a confusão com a Mísia - essa ignorância justifica o papel Télefo na continuidade do poema.

${ }^{56}$ Um escólio (DINDORFIUS) ao verso 59 do canto I da Ilíada contém uma versão da história de Télefo atribuída aos $v \varepsilon \omega \dot{\tau \varepsilon \rho o t, ~ q u e ~ o ~ c o n s i d e r a m ~ o ~ g u i a ~ d o s ~ g r e g o s ~ a ~ T r o ́ i a ~-~ d i f e r e n t e m e n t e ~ d e ~ H o m e r o, ~ q u e ~ c o n c e d e ~}$ tal missão a Calcante (Ilíada, I, v. 68-72). Nessa versão, o fato de Télefo ter ficado preso em uma videira resultaria da vontade de Dioniso, irritado com Télefo por este haver privado o deus de suas honras.
} 
Além do relato de Proclus, Pausânias $(X, 26,4)^{57}$ atesta a existência no poema de um episódio com Aquiles e Pirro no palácio de Licomedes: nos Cantos Cíprios, Licomedes atribuía o nome de Pirro ao neto por conta de seus cabelos ruivos, e Fênix o de Neoptólemo por ser filho de alguém que começou jovem a guerrear ${ }^{58}$.

Em outro épico do ciclo troiano, a Pequena Ilíada ${ }^{59}$, também se narrava a ida de Aquiles à ilha de Ciros, empurrado por uma tempestade, após a aventura com Télefo, na Mísia. Tal repetição leva Severyns (1928b, p. 285-291) a empreender uma interessante pesquisa. De início, examina duas passagens da Ilíada (IX, v. 666-668 e XIX, v. 326-333) relativas ao elo entre Aquiles e Ciros: os textos mostram que o herói tomou essa ilha de assalto (pois dólopes descontentes com o governo de Peleu queriam se libertar), fez cativos e nela possui um filho, Neoptólemo. Essa versão difere da mais difundida, na qual Aquiles é escondido em Ciros entre as filhas do rei Licomedes para não ir à guerra. Em seguida, Severyns elenca todas as alusões encontradas em escólios e fragmentos dos épicos acerca desse assunto (um total de 16), analisa-as e expõe sua hipótese para a versão dos Cantos Cíprios: Aquiles é educado pelo centauro Quíron; raptada Helena e feitos os primeiros preparativos para a guerra de Tróia, Peleu, sabendo que seu filho morrerá caso participe da guerra, resolve conduzi-lo a Ciros e confiá-lo ao rei Licomedes; este disfarça o jovem com roupas femininas e o esconde entre suas filhas; Aquiles engravida Deidâmia, filha do rei; a embaixada grega formada por Odisseu, Fênix e Nestor chega e, usando um ardil de Odisseu, descobre Aquiles, que é forçado a participar da expedição contra Tróia; mais tarde, depois da aventura na Mísia contra Télefo, Aquiles é levado por uma tempestade outra vez a Ciros e nessa ocasião se casa oficialmente com Deidâmia, tendo já o filho nascido ${ }^{60}$. Tal hipótese não entra em conflito com o resumo de Proclus.

Quanto a Télefo, o tempo passa, e seu ferimento recusa-se a sarar. Apolo então lhe diz que somente seria curado quando aquele que lhe causou a ferida cuidasse dela. Com isso, Télefo encaminha-se para Argos, envolvido em trapos ${ }^{61}$. Chegando à cidade,

\footnotetext{
${ }^{57}$ Fr. 16 D, fr. $19 \mathrm{~W}$.

${ }^{58}$ De $\nu \varepsilon ́ o \zeta+\pi o \lambda \varepsilon \mu \varepsilon ́ \omega(\pi \tau 0 \lambda \varepsilon \mu \varepsilon ́ \omega)$.

${ }^{59}$ Escólio (DINDORFIUS) à Ilíada, XIX, v. 316 = fr. 4 D e W.

${ }^{60}$ A maior parte desse relato provém de escólios ao verso 326 do canto XIX da Ilíada.

${ }^{61}$ Severyns (1928b, p. 295, n. 2) e Jouan (1966, p. 251) julgam que o detalhe da vestimenta não fazia parte do épico, viria da peça Télefo, de Eurípides. Ver o ensaio de reconstituição e o estudo que Jouan (p. 222-255) faz dessa tragédia, cotejando, quando possível, seus episódios com os correspondentes dos Cantos Cíprios.
} 
suplica a Aquiles que o cure, prometendo-lhe em troca guiar os gregos até Ílion. Acreditando que Télefo seria de fato um bom guia para a expedição, Aquiles resolve curálo: o pelida então raspa a crosta oxidada do cobre de sua lança do Pélio sobre o ferimento de Télefo. Curado, Télefo revela o caminho de Ílion aos gregos, sendo a veracidade de suas informações atestada por profecias do adivinho Calcante ${ }^{62}$.

Servindo-se principalmente de representações feitas em um vaso ático do princípio do século V a.C., a taça de Hierão, Jouan (1966, p. 48-49) propõe uma reconstituição do episódio de Télefo no palácio de Agamêmnon, em Argos: no interior do palácio, Aquiles ameaça matar Télefo, ainda irritado por ter este ferido Pátroclo na Mísia; Télefo encontra refúgio junto ao altar doméstico; nesse momento, o próprio Pátroclo intervém e, com o auxílio de Nestor, acaba convencendo Aquiles a curar Télefo.

Enquanto a frota se prepara em Áulis para uma segunda expedição contra Ílion, Agamêmnon mata um cervo em uma caçada e se vangloria de ser melhor que Ártemis. Zangada, a deusa envia tempestades, que impedem a frota de zarpar. Calcante explica a razão do mau tempo e diz que não poderão navegar enquanto a mais bela filha de Agamêmnon não for imolada em honra de Ártemis. Decidindo-se a realizar o sacrifício, Agamêmnon envia Odisseu e Taltíbio a Clitemnestra para perguntar por Ifigênia, afirmando que a jovem estava prometida a Aquiles em recompensa pela participação deste na expedição. Iludida, a mãe entrega a filha. Quando Ifigênia chega, o altar já está pronto para sua imolação. No entanto Ártemis retira a virgem do altar, colocando em seu lugar um cervo, e a leva para junto dos Tauros, na Criméia, onde lhe concede a imortalidade ${ }^{63}$.

Findo o ritual, zarpam outra vez rumo a Ílion ${ }^{64}$. Alcançam Tênedos, ilha governada por Tenes, filho de Próclea e Cicno (ou de Apolo), sendo este o rei de Colono, cidade situada no litoral troiano em frente de Tênedos ${ }^{65}$. Ao ver os gregos, Tenes tenta repeli-los atirando pedras, mas acaba morto por Aquiles, apesar de este ter sido avisado por Tétis para não matar Tenes, porque Apolo, por sua vez, haveria de se vingar levando o pelida à morte.

Controlada a situação, os gregos organizam um banquete, para o qual Aquiles é

\footnotetext{
62 APOLODORO, Epítome, 3, 20.

${ }^{63}$ APOLODORO, Epítome, 3, 21-22.

${ }^{64}$ Comentando o pârodos de Ifigênia em Áulis, de Eurípides, Jouan (1966, p. 295-298) aborda a hipótese da existência de um catálogo dos gregos nessa epopéia, expresso durante os preparativos para essa segunda partida. ${ }^{65}$ APOLODORO, Epítome, 3, 23. A história da separação entre Cicno e Tenes e da chegada deste a Tênedos também é contada por Apolodoro (Epítome, 3, 24-25).
} 
convidado de última hora, o que o leva a discutir com Agamêmnon. Enquanto se banqueteavam, Filoctetes, detentor do arco de Héracles, é picado por uma serpente aquática. Sendo o ferimento incurável e fonte de uma terrível pestilência, os gregos são obrigados a abandoná-lo em Lemnos ${ }^{66}$.

Enfim chegam a Ílion. Lembrando o oráculo segundo o qual o primeiro a grego a descer seria o primeiro a morrer, Tétis aconselha Aquiles a esperar um pouco para deixar seu barco. Os troianos acorrem à praia tentando impedir o desembarque. O primeiro aqueu a lançar-se ao combate é Protesilau: após matar muitos troianos, o jovem, recémcasado, encontra a morte nas mãos de Heitor ${ }^{67}$. Morto o herói, Polidora, sua infeliz esposa, continua e devotar-lhe amor: erige uma estátua do marido e lhe dedica carícias e oferendas $^{68}$.

Aquiles só então desembarca, acompanhado dos mirmidões. Em suas primeiras ações, mata Cicno, filho de Posídon, atirando-lhe uma pedra na cabeça. Vendo Cicno morto, os troianos voltam para a cidade ${ }^{69}$. Com isso, os gregos saem dos barcos sem temor, perseguem os troianos, enchem a planície de corpos e conseguem sitiar os inimigos.

Os gregos trazem os barcos para terra; cuidam em seguida de seus mortos e enviam uma embaixada aos troianos solicitando a devolução de Helena e do tesouro. Os troianos recusam. Diante dessa resposta, consolida-se o cerco de Ílion ${ }^{70}$. Instalados, os gregos fazem um reconhecimento dos arredores, o que lhes permite saquear cidades próximas.

\footnotetext{
${ }^{66}$ APOLODORO, Epítome, 3, 26-27 - com o ferimento de Filoctetes ocorrendo durante um sacrifício em honra de Apolo, também provocado por uma serpente aquática, proveniente do altar do deus. Referido na Ilíada (II, v. 716-728).

${ }^{67}$ APOLODORO, Epítome, 3, 29-30.

${ }^{68} \mathrm{O}$ poema abordaria ainda o sofrimento e o suicídio de Polidora - nome cuja etimologia indica o culto ao marido: "a que cobre de dons". Ela seria filha de Cleópatra e Meléagro, o filho de Oineu (PAUSÂNIAS, 4, 2,7 = fr. 18 D, fr. 22 W). Pausânias estabelece uma genealogia que liga a esposa de Protesilau a Idas (irmão de Linceu) e, conseqüentemente, às aventuras dos Dióscuros presentes nos Cantos Cíprios. Segundo Apolodoro (Epítome, 3, 30), o nome da esposa seria "Laodamia"; mas isso provavelmente vem da peça (perdida) composta por Eurípides sobre esse tema. Jouan (1966, p. 329-330) faz um ensaio de reconstituição desse episódio nos Cantos Cíprios: após a chegada às margens de Tróia, cientes do oráculo, os gregos hesitam, temem desembarcar; então Protesilau, impetuoso, avança seu barco, salta e enfrenta os troianos, que esperavam os gregos; depois de uma aristia, morre sob os golpes de Heitor.

${ }^{69}$ APOLODORO, Epítome, 3, 31. Os troianos recuam com a morte de Cicno porque esse herói era considerado invulnerável (Aristóteles, Ret., II, 22, 1396b). Essa morte retoma o modo como Tenes, o filho de Cicno, tentou repelir os gregos em Tênedos.

${ }^{70}$ A ordem dos fatos parece estranha: primeiramente o ataque, depois a embaixada. Essa embaixada é abordada na Ilíada (III, v. 203-224; XI, v. 138-141), mas nada é informado quanto ao momento em que acontece. Heródoto também a expressa (Histórias, II, 118); segundo ele, depois que os gregos desembarcam e se instalam em Tróia, enviam a embaixada. Em Apolodoro (Epítome, 3, 28-29), do mar entre Tênedos e Tróia, os gregos enviam Odisseu e Menelau para reclamar a devolução de Helena e do tesouro; em assembléia, os troianos decidem não apenas não aceitar as exigências gregas, mas também matar os emissários, que são salvos por Antenor; depois disso, os gregos começam a desembarcar.
} 
Depois disso, Aquiles é tomado do desejo de ver Helena. Diante disso, Afrodite e Tétis proporcionam um encontro entre os dois.

Tempos depois, os gregos manifestam a intenção de retornar para suas casas; e Aquiles os reprime ${ }^{71}$.

Essa atitude de Aquiles derivaria provavelmente de seu encontro com Helena. Esse passo do poema relembra o plano de Zeus, do qual seriam os instrumentos principais. Para Severyns (1928b, p. 304), esse episódio viria em seguida ao da embaixada e nele deveria existir um elogio da beleza de Helena, o que teria despertado em Aquiles a vontade de contemplá-la, pois ainda não a conhecia de fato, era jovem demais na época do rapto. Essa hipótese confere mais coerência ao enredo.

Explorando outra vez a região, Aquiles encontra Enéias pastoreando seu gado no monte Ida em companhia de alguns troianos. O pelida investe contra eles; Enéias escapa, mas os vaqueiros e um filho de Príamo, Mestor, são mortos. E Aquiles rouba o $\operatorname{gado}^{72}$.

Após essa empresa, Aquiles devasta Lirnesso, Pédaso, de onde traz Briseide ${ }^{73}, e$ várias outras cidades da redondeza.

Ele ainda encontra Troilo nos arredores de Ílion e o mata junto de um altar de Apolo Timbreu ${ }^{74}$.

Na Ilíada, ocorre uma única menção a Troilo, no canto XXIV (v. 257), quando Príamo lamentando a morte de Heitor, relembra os filhos mortos - curiosamente, o monarca refere-se à perda de Mestor e Troilo, cujas mortes constituiriam dois episódios sucessivos dos Cantos Cíprios segundo Proclus e Apolodoro. De acordo com um escólio (MAASS) ao referido verso homérico, na peça (perdida) Troilo, de Sófocles (RADT, 1977, fr. 618-635), o filho de Príamo teria sido emboscado por Aquiles enquanto exercitava seus cavalos perto do templo de Apolo Timbreu.

Discutindo esse episódio, Severyns (1928b, p. 305-306) e Jouan (1966, p. 369) exibem uma reconstituição feita por C. Robert (1881), fundamentada em pinturas de vasos de figuras

\footnotetext{
${ }^{71}$ Desempenhando o papel de Odisseu e Diomedes na Ilíada (respectivamente em II, v. 172-335 e IX, v. 17-49).

${ }^{72}$ APOLODORO, Epítome, 3, 32. Episódio aludido na Ilíada (XX, v. 90-93; v. 188-194). De acordo com Pausânias (X, 26, 1 = fr. 23 D, fr. 28 W), no poema a esposa de Enéias chamar-se-ia Eurídice.

${ }^{73}$ Escólio (MAASS) à Ilíada, XVI, v. 57 = fr. 21 D, fr. 23 W. Na Ilíada (II, v. 688-693), Aquiles captura Briseide em Lirnesso.

${ }^{74}$ APOLODORO, Epitome, 3, 32.
} 
negras $^{75}$ : nesse momento da guerra, pouco depois do desembarque, os gregos ainda se encontram longe de Tróia e não conhecem bem os arredores; isso concede aos troianos uma relativa tranqüilidade para se aventurar fora dos muros e realizar determinadas atividades comuns à época de paz; por conseguinte, Polixena e Troilo saem certo dia de Tróia e dirigemse a uma fonte, ela para buscar água, ele para dar de beber aos cavalos; em uma emboscada, Aquiles os ataca; ela consegue fugir e retornar à cidade, mas Troilo é alcançado, levado até o templo de Apolo Timbreu e morto; Antenor percebe Polixena chegar em desespero e avisa Príamo do perigo; e Polites, tendo visto o drama de um posto de vigilância, adverte os troianos e parte em companhia de Heitor, Deífobo, Enéias e o peônio Pirecmes em socorro do jovem; no entanto, quando chegam, já é tarde, Aquiles lança-lhes a cabeça de Troilo; mas então é Aquiles que se vê em perigo, cercado pela elite troiana; em seu socorro vêm Atena, Tétis e Hermes, o deus das emboscadas; com o amparo das divindades, o herói consegue escapar e retorna aos barcos.

Após a emboscada de Troilo, Aquiles penetra na cidade à noite e captura Licáon, outro filho de Príamo. Pátroclo leva o prisioneiro para Lemnos e o vende como escravo ${ }^{76}$.

Acontece uma partilha do butim conseguido com os saques já efetuados. Aquiles toma Briseide como sua parte; Agamêmnon, Criseida, capturada em Tebas Hipoplácia, onde se encontrava por conta de sacrifícios em honra de Ártemis ${ }^{77}$.

Tempos depois, a fome castiga os gregos. Nessa circunstância, Palamedes aconselha Agamêmnon a buscar as filhas de Ânio para alimentá-los. Uma passagem por Delos é então recordada: rumo a Ílion, os gregos aportaram em Delos, onde o rei Ânio, filho e sacerdote de Apolo, recebeu-os calorosamente e, apoiando-se em uma profecia, tentou convencê-los a permanecer na ilha por nove anos; com efeito, instruído pelo conhecimento divino de seu pai, vaticinou que a expedição enfrentaria nove anos de lutas duras e somente conseguiria a vitória no décimo; durante esses anos difíceis, os gregos poderiam permanecer em Delos, onde a subsistência seria assegurada por suas filhas, Eno, Espermo e Elais ${ }^{78}$, as vinhateiras, às quais Dioniso concedera o poder de gerar à

\footnotetext{
${ }^{75}$ BOARDMAN, 2001, p. 52, fig. 62; p. 64, fig. 84. Para vasos com o episódio de Troilo atribuídos a Polignoto (ativo entre 450-420 a. C.), ver Matheson (1995, p. 249-250). Williams (1960, p. 146-147) também comenta esse episódio a partir de pinturas.

${ }^{76}$ Referido na Ilíada (XXI, v. 34-44 e XXIII, v. 746-747).

${ }^{77}$ Comentário de Eustácio à Ilíada $(119,4)=$ fr. 22, fr. 24 W. Este relato está em acordo com os versos 365-369 do canto I da Ilíada. Davies (1989a, p. 48-49) reitera aqui a idéia de que algumas dessas coincidências entre o conteúdo dos Cantos Cíprios e o da Ilíada podem representar alterações impostas por Proclus para tornar o poema uma espécie de "prefácio" da Ilíada.

${ }^{78}$ Esses nomes evocam respectivamente as idéias de "vinho", "semente" e "óleo".
} 
vontade os produtos referentes aos seus nomes; os gregos, porém, recusaram a oferta e partiram. O conselho é seguido, e elas são conduzidas ao Reteu ${ }^{79}$.

Em certo dia desse período de fome, Palamedes vai pescar. Odisseu, auxiliado por Diomedes, aproveita a oportunidade para vingar-se de Palamedes afogando-o ${ }^{80}$.

A morte de Palamedes constituiria o último acontecimento do poema. Severyns (1928b, p. 309-313) julga que as vinhateiras seriam lembradas durante esse episódio porque as circunstâncias denotariam um momento de fome (o guerreiro encontrava-se pescando, reflexo de carência de alimento); e somente nessa ocasião a passagem por Delos seria relatada no poema, em forma de recordação. Sem tentar reconstituir os eventos, Debiasi (2004, p. 118122) também supõe que Ânio e suas filhas participariam do poema vinculados a Palamedes e fornece mais um argumento para tal hipótese: ao motivo da fome junta-se uma origem comum a Palamedes e Ânio, ambos são originários da Eubéia.

Jouan (1966, p. 357-359) tem outra opinião a respeito das vinhateiras e tece um interessante comentário acerca do papel de Palamedes nos Cantos Cíprios: o episódio das filhas do rei Ânio não figuraria originalmente no poema, teria sido adicionado mais tarde ao de Palamedes, provavelmente no período alexandrino; esse herói, por sua vez, rivalizaria com Odisseu em sabedoria e engenhosidade, o que alimentaria a inveja e a raiva que este sentia por aquele; por conseguinte, Palamedes funcionaria como um contraponto para se avaliar melhor o caráter de Odisseu, que recebe aqui um tratamento bem menos glorioso do que aquele concedido pelos poemas homéricos ${ }^{81}$.

Findados os episódios dos Cantos Cíprios, o sumário de Proclus já anuncia a Ilíada.

\section{Etíope}

Dando seqüência aos eventos narrados na Ilíada, o Etíope (Aïlozís) tem seu título derivado do herói etíope Mêmnon. Sua autoria é atribuída a Arctino de Mileto ${ }^{82}$. Em termos

\footnotetext{
79 A história das vinhateiras e sua relação com os Cantos Cíprios emergem em escólios (LEONE) aos versos 570 b, 580 e 581 do poema de Licofron (= fr. 19 D, fr. 26 W). Sobre as vinhateiras, ver também Ovídio (Metamorfoses, XIII, v. 632-674) e Sérvio (ad Aen., III, v. 80).

${ }^{80}$ PAUSÂNIAS, $10,31,2$ = fr. $20 \mathrm{D}$, fr. $27 \mathrm{~W}$.

${ }^{81}$ O Odisseu de caráter recriminável revelado nesse épico é retomado pelos trágicos gregos, sobretudo Eurípides, e pelos poetas romanos, sobretudo Virgílio.

${ }^{82}$ Severyns (1928b, p. 313) crê recente a tradição que atribui tal poema a Arctino. Burgess (2001, p. 163) levanta uma hipótese que vai ao encontro dessa opinião de Severyns: o autor desse épico seria desconhecido; então
} 
de datação, Jouan (1966, p. 26-27) estima que pertencesse à camada de epopéias mais antiga depois da Ilíada, tendo sido composto entre 725 e 700 a. C, época muito próxima (e julga talvez até mesmo anterior) à da criação da Odisséia; Huxley (1969, p. 144) também indica o final no século VIII a. C.; já Debiasi (2004, p. 131 e n. 53) sugere o floruit de Arctino no começo do século VII a. C.

O poema deveria apresentar duas repartições bem marcadas: a primeira constituída de eventos envolvendo Pentesiléia; a segunda, Mêmnon ${ }^{83}$. De acordo com Proclus, esses eventos distribuíam-se em cinco livros.

Há pouquíssimos fragmentos do Etíope; destarte, os principais dados para a reconstituição de seu conteúdo provêm da Chrestomathia de Proclus e do Epítome (5, 1-6) da Biblioteca de Apolodoro.

Após a morte de Heitor, o maior guerreiro troiano, outros heróis vieram em auxílio das forças de Príamo; nesse contexto, o poema principiaria com a chegada de Pentesiléia, filha de Ares, amazona oriunda da Trácia.

Pentesiléia chega. Encaminhou-se a Ílion por seu ardor guerreiro e, sobretudo, para ser purificada por Príamo da morte de Hipólita, um crime involuntário ${ }^{84}$. Em combate, envia ao Hades um grande número de gregos, entre os quais o grande Macáon. Sua aristia, no entanto, finda quanto se defronta com Aquiles. Os troianos então lhe rendem honras fúnebres.

Depois disso, Aquiles é insultado por Tersites, especialmente em função de um sentimento amoroso que o pelida demonstra por Pentesiléia: vendo-a morta, ter-se-ia apaixonado por ela. Perdendo o controle face aos insultos de Tersites, Aquiles o mata com um soco. Os gregos recriminam o ato e discutem a conduta do herói ${ }^{85}$. Em consequiência, Aquiles viaja para a ilha de Lesbos, onde executa sacrifícios em honra de Apolo, Ártemis e Leto e é purificado do crime com o intermédio de Odisseu.

estudiosos antigos, reconhecendo nele um fundo milésio (sobretudo no episódio da Ilha Branca), teriam escolhido um poeta milésio arcaico de renome a quem atribuíram a composição.

${ }^{83}$ Pentesiléia não é mencionada nos poemas homéricos; Mêmnon, por sua vez, aparece na Odisséia (IV, v. 188 e XI, v. 522 - passagens que podem ser interpolações).

${ }^{84}$ Quinto de Esmirna (Posthoméricas, I, v. 18-35) conta que Pentesiléia, tendo ceifado a vida de sua irmã durante uma caçada, via-se perseguida pelas Erínias, daí a necessidade de buscar a purificação desse crime em Tróia.

${ }^{85}$ Davies (1989a, p. 54) ressalta certo desacordo entre o Tersites deste poema, cuja morte desencadeia uma revolta, e o impopular Tersites do canto II da Ilíada, punido por Odisseu. No poema Posthoméricas (I, v. 722781), a morte de Tersites revolta Diomedes, e uma relação de parentesco entre eles aflora: Tersites seria filho de Ágrios, irmão de Oineu, sendo este avô de Diomedes. Nessa tradição, Tersites é, portanto, um nobre diferentemente da homérica. 
Discute-se a possibilidade de que ao começo do Etíope pertença uma variante do último verso da Ilíada (XXIV, v. 804a), que anuncia a chegada de Pentesiléia, filha de Ares,

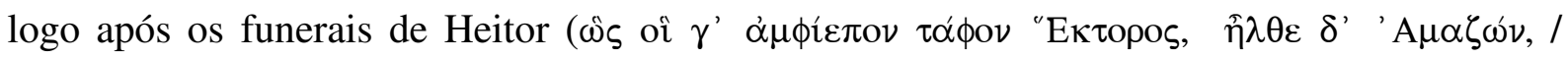

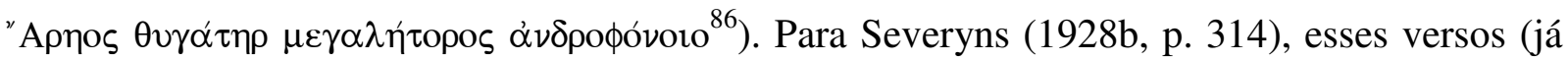
existentes) devem ter sido adicionados a alguma edição alexandrina de Homero, com o objetivo de estabelecer uma seqüência harmoniosa entre a Ilíada e o Etíope.

Tal variante é significativa para uma ponderação de E. Christian Kopff (1981). Analisando a relação entre a Eneida e os poemas do ciclo troiano, esse estudioso (p. 930-931) defende a hipótese de que a chegada de Pentesiléia não caracterizaria o começo do poema, antes haveria uma retomada da morte de Heitor, episódio que seria o paradigma da imagem apresentada no templo de Juno, em Cartago (Eneida, I, v. 483-487): a chegada e a ação de Pentesiléia constituiriam a segunda parte do Etíope, e a variante do verso final da Ilíada marcaria justamente a passagem do episódio da morte de Heitor para o da chegada da amazona. Kopff propõe ainda uma reconstituição para essas duas partes: no princípio do poema, Aquiles comporta-se como um ser cruel, mutilando e profanando o corpo de Heitor diante da família deste e dos muros da cidade que este protegia; Príamo espera que a vinda de Pentesiléia salve Tróia; a amazona não salva a cidade, mas salva Aquiles: ao contemplar a face da mulher que acaba de matar, o guerreiro começa a compreender o que está fazendo; assim, quando Tersites mutila o corpo de Pentesiléia, Aquiles é ultrajado e o mata; poluído pelo sangue, precisa ser purificado por Odisseu. Essa hipótese é tentadora e no capítulo II (parte I), por ocasião do estudo da referida passagem da Eneida, será apreciada com a argumentação apresentada por Kopff.

Após Pentesiléia, em auxílio dos troianos vem Mêmnon, o filho de Eos e de Titono, troiano que ela arrebatou e a quem concedeu a imortalidade, esquecendo-se, todavia, de lhe atribuir a juventude eterna. Mêmnon dispõe de armas feitas por Hefesto ${ }^{87}$, como Aquiles, e traz consigo uma grande força de etíopes.

Tétis previne seu filho dos fatos decorrentes da chegada de Mêmnon.

\footnotetext{
${ }^{86}$ Escólio (MAASS) ao verso 804a do canto XXIV da Ilíada $=$ Fr. 1 W do Etíope.

${ }^{87}$ Davies (1989a, p. 55) cita os versos 383 e 384 do canto VIII da Eneida como uma possível indicação de que, no Etíope, Eos convença Hefesto a confeccionar armas para seu filho com um método semelhante ao empregado por Tétis no canto XVIII da Ilíada.
} 
Em combate, o guerreiro etíope demonstra sua excelência e mata Antíloco, filho de Nestor ${ }^{88}$. Contudo, Aquiles o enfrenta e o mata. Morto o filho, Eos implora a Zeus o direito de lhe conceder a imortalidade; e o deus aquiesce.

Depois dessa façanha, Aquiles tenta empurrar os troianos para o interior da cidade; nesse momento, seu destino se consuma: nas portas Céias, uma flecha atinge seu calcanhar, atirada por Páris, guiada por Apolo ${ }^{89}$.

Tem curso então uma terrível luta pelo corpo do herói. Ájax mata Glauco, recupera as armas de Aquiles e pede aos gregos que as levem para os barcos; em seguida, pega o corpo do herói e o carrega na direção dos barcos, enquanto Odisseu reprime os troianos.

A morte de Aquiles seria o momento mais elevado do poema ${ }^{90}$. Severyns (1928b, p. 321-322) acredita que as imagens de uma ânfora calcídica de figuras negras, datada do século VI a.C., inspiraram-se no episódio da luta pelo corpo desse herói, dada a coincidência existente entre a narrativa das imagens e a de Apolodoro (Epítome, 5, 4). Com base nessas duas fontes, reconstitui assim o episódio do Etíope (p. 322):

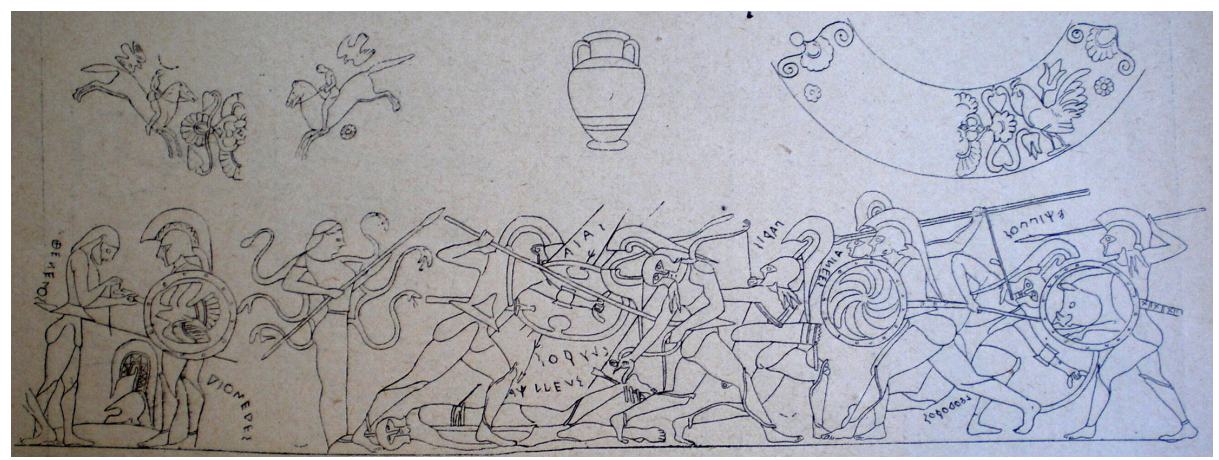

Atena, armada de uma lança e rodeada de serpentes, observa o combate de gregos e troianos em volta do corpo de Aquiles. No centro da composição, jaz Aquiles, atingido por duas flechas, uma no calcanhar, outra no peito.

O troiano Glauco abaixa-se para atar ao pé de Aquiles uma correia com a qual o cadáver será arrastado para fora do campo de batalha. Enquanto Glauco ocupa-se dessa tarefa, Ájax, sob uma chuva de piques e flechas, atinge-o com um

${ }^{88}$ Davies (1989a, p. 56) levanta a possibilidade de haver nesse épico uma cena de despedida entre Nestor e Antíloco; como argumento, supõe que, assim como a referência a Eos no verso 384, Virgílio também possa ter se inspirado no Etíope para compor a cena de despedida entre Evandro e Palante no canto VIII da Eneida.

${ }^{89}$ Como Heitor, ao morrer, prediz a Aquiles na Ilíada (XXII, v. 356-360). Quanto a esse único ponto vulnerável do pelida, questão ausente dos poemas homéricos, Davies (1989a, p. 58) se pergunta se o Etíope já apresentaria tal motivo, o que faria dele, até onde se sabe, a primeira fonte literária da lenda do calcanhar de Aquiles.

${ }^{90}$ E West (2003a, p. 14) acrescenta que esse clímax compara-se ao da Ilíada, a morte de Heitor. Esse paralelo alimenta a hipótese de Kopff, a de uma retomada da morte de Heitor nesse épico. 
golpe de lança. À direita, Páris, puxando o arco, é seguido de dois guerreiros com a lança no alto, um dos quais é Enéias; um pouco mais à direita, Laódoco, filho de Antenor, ferido, dobra o joelho, e outro guerreiro, Equipo, lança-se ao combate.

À esquerda, e separado do grupo de combatentes pela imagem de Atena, Estênelo trata da mão ferida de Diomedes. ${ }^{91}$

Um dos anúncios feitos na Ilíada envolvendo a morte de Aquiles diz respeito a Enéias: no canto XX (v. 332-339), quando este herói, induzido por Apolo, tenta enfrentar Aquiles, Posídon aparece e o dissuade de tal insanidade; na ocasião, o deus lhe diz que, tão logo Aquiles pereça, pode lançar-se ao combate sem temor, pois nenhum dânao poderá vencê-lo. Essa revelação haveria de se cumprir em uma época posterior aos fatos da Ilíada; considerando sua importância e a maneira como o poema homérico a deixa pronta para ser desenvolvida, seria natural que outro épico do ciclo troiano a concretizasse. A morte de Aquiles ocorre no Etíope. Logo, seguindo a revelação de Posídon, seria oportuna a ocorrência de uma aristia de Enéias nesse episódio. E, nessa reconstituição de Severyns, vê-se justamente Enéias tomando parte em um dos acontecimentos mais importantes da guerra de Tróia - cabe ressaltar que na Odisséia (XXIV, v. 36-42) esse evento é descrito por Agamêmnon como um combate intenso, que durou um dia inteiro e do qual participaram grandes guerreiros troianos e gregos. Em conclusão, desenvolvendo o referido anúncio da Ilíada, o Etíope deve ter concedido a Enéias uma valorosa aristia nesse momento, logo após a morte de Aquiles - a relevância desse fato para nosso estudo há de se confirmar no capítulo seguinte.

De volta ao acampamento, os gregos fazem o funeral de Antíloco e preparam o corpo de Aquiles. Tétis então chega com suas irmãs, as Nereides, e com as Musas para prantear o herói. Ela arrebata o filho da pira e o leva para Leuce, a Ilha Branca, no Mar Negro $^{92}$. Quanto aos gregos, erigem um monumento funerário e organizam jogos em

\footnotetext{
${ }^{91}$ Desenho apresentado por Reinach (1899, vol. I, p. 82). Texto original (sic):

"Athéna, armée d'une lance, et environnée de serpents, regarde le combat des Grecs et des Troyens autour du corps d'Achille. Au centre de la composition gît A $\chi \imath \lambda \lambda \varepsilon \cup \varsigma$, percé de deux flèches, l'une dans le talon, l'autre dans la poitrine.

Le Troyen $\Gamma \lambda(\alpha)$ vqo se baisse pour attacher au pied d'Achille une lanière avec laquelle le cadavre sera traîné hors du champ de bataille. Tandis que Glaucos est occupé à ce travail, Atas environné d'une pluie de piques et

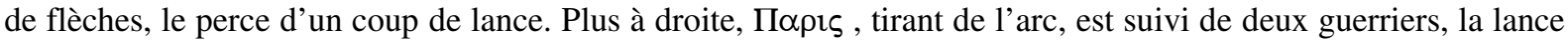

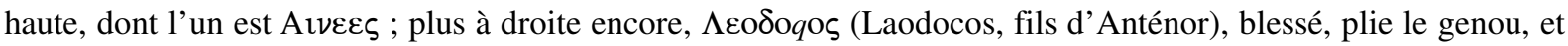

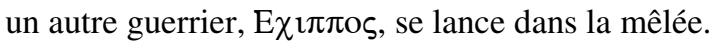

À gauche, et séparé, par la figure d'Athéna, du groupe combattant, $\Sigma \theta \varepsilon v \varepsilon \lambda$ os panse la main blessée de $\Delta$ 1о $\mu \varepsilon \delta \varepsilon \varsigma . "$

${ }^{92}$ Burgess (2001, p. 163) e Debiasi (2004, p. 32, n. 88 e p.124-125) discutem a relação entre a região dessa ilha, de antiga colonização milésia, e a autoria do Etíope.
} 
honra do guerreiro: Eumelo vence a competição de carros; Diomedes, a corrida de curta distância; Ájax, o arremesso de disco; Teucro, o concurso de arco e flecha. E as armas de Aquiles são oferecidas como prêmio ao herói mais valoroso, o que provoca uma disputa entre Ájax e Odisseu ${ }^{93}$. E Odisseu conquista as armas.

Transtornado, Ájax suicida-se.

Embora Proclus não mencione o suicídio de Ájax, sua presença neste épico é atestada por um escólio ao verso 58 b da quarta Ístmica de Píndaro ${ }^{94}$. Davies (1989a, p. 60) e West (2003a, p. 12) julgam que Proclus tenha suprimido esse episódio do final do poema porque ele também figura na Pequena Ilíada. Severyns (1928b, p. 325), por sua vez, postula não se dever a Proclos essa suposta supressão, mas a quem retirou da Chrestomathia uma parte do capítulo referente ao ciclo troiano para incluí-la, como prefácio, em uma edição de Homero. E Debiasi (2004, p. 132 e n. 60) vai mais longe: acredita que não apenas o suicídio de Ájax mas também a disputa pelas armas de Aquiles deveriam fazer parte desses dois épicos.

Para concluir, uma breve sondagem da importância de Mêmnon e conseqüentemente desse épico na gesta troiana.

Davies (1989a, p. 55 e 59) reconhece no Etíope um paralelo entre Mêmnon e Aquiles: Hefesto confeccionou as armas dos dois guerreiros; a morte de Mêmnon conduziu Aquiles ao fim que lhe era destinado; mortos, os dois receberam a imortalidade e foram transportados por suas mães para outra região (Mêmnon para o Leste, terra dos negros, Aquiles para a Ilha Branca, Leuce). Podemos acrescentar a esse paralelo a origem dos heróis: Aquiles, filho de Tétis (filha de Nereu), divindade marinha, e de um mortal; Mêmnon, filho de Eos, que sai do mar toda manhã, e de um mortal. Debiasi (2001, p. 125) chega mesmo a qualificar Mêmnon de "alter ego de Aquiles".

Pausânias descreve representações envolvendo Mêmnon e Aquiles. Um magnífico trono em Amicléia, obra do arquiteto e escultor Báticles de Magnésia (séc. VI a.C.), expunha o combate entre os dois (III, 18, 12). Esse combate também figurava em uma arca de cedro recoberta de figuras (umas em marfim, outras em ouro e outras entalhadas na própria madeira), na qual Cípselo (governante de Corinto aproximadamente de 655 a 625 a. C.),

\footnotetext{
${ }^{93}$ Uma versão dessa disputa aflora na oitava Neméia de Píndaro. O combate pelo corpo de Aquiles, a preparação do cadáver para as cerimônias, o lamento de Tétis, Nereides e Musas e os jogos fúnebres aparecem na Odisséia (XXIV, v. 36-92) - passagem que Severyns (1928b, p. 324) julga inspirada no Etíope, considerando que Aristarco delimitava o final da Odisséia no verso 296 do canto XXIII.

${ }^{94}$ Fr. 1 D, fr. 6 W.
} 
recém-nascido, foi escondido por sua mãe para não ser apanhado por membros de sua própria família, os Bacchiadae; mais tarde, essa arca foi oferecida em Olímpia pelos descendentes de Cípselo, em agradecimento $(\mathrm{V}, 19,1)^{95}$. Em um pedestal semicircular colocado em um ângulo do Hippodamium, em Olímpia, dedicado pelo povo de Apolônia, no mar Jônio, havia um grupo de estátuas: no centro, encontravam-se Zeus, Tétis e Dia, estas suplicando ao deus pelos seus filhos; nas extremidades, Aquiles e Mêmnon, opondo-se em posição de combate; e assim outros guerreiros se opunham, sempre um grego de um lado relacionado a um "bárbaro" do outro: Odisseu e Heleno; Alexandre e Menelau; Diomedes e Enéias; Ájax, filho de Télamon, e Deífobo (V, 22, 2).

Duas peças perdidas de Ésquilo também retratavam o príncipe etíope: Mêmnon e

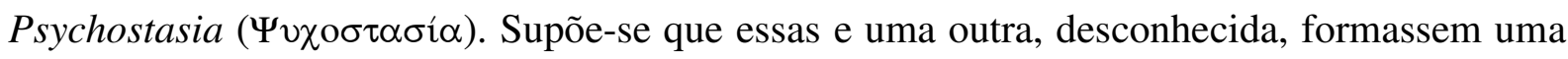
trilogia em torno de Mêmnon ${ }^{96}$. Dentre elas, a Psychostasia desperta maior interesse. No tratado De audiendis poetis (2,17 A), composto por volta do ano 80 de nossa era, Plutarco afirma que, inspirado no episódio do canto XXII da Ilíada (v. 208-213), Ésquilo teria escrito a tragédia Psychostasia, na qual Zeus pesava as almas de Aquiles e Mêmnon, tendo ao seu lado Tétis e Eos, suplicando por seus respectivos filhos. Fraenkel (1962, p. 229), comentando o verso 438 do Agamêmnon de Ésquilo, acredita que esse autor tenha de fato sido influenciado

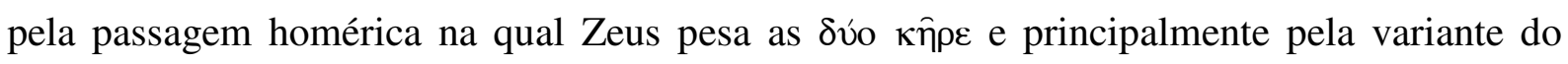

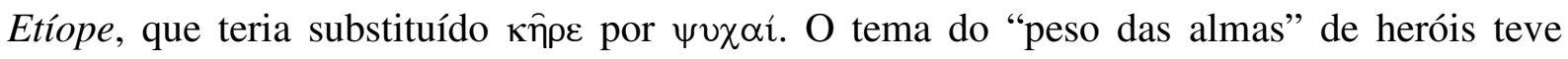
grande repercussão na Antigüidade: Taplin (1977, p. 431), apoiando-se em dados de CaskeyBeazley (1931), atesta que a psychostasia de Aquiles e Mêmnon aparece em pelo menos nove vasos datados de antes de Ésquilo até cerca de 450 a.C. e que em apenas um deles Zeus segura a balança que pesa o destino dos heróis, nos demais é Hermes que a sustém. A predominância de Hermes e a presença de Mêmnon nesse episódio põem em dúvida o fato de tais pinturas serem representações do episódio do canto XXII da Ilíada em que Zeus pesa o destino de Aquiles e Heitor; em decorrência, acredita-se que a fonte delas seja o Etíope, poema no qual o tema da psychostasia desempenharia um relevante papel. Com isso, Taplin (p. 431), contestando a opinião de Plutarco, considera o Etíope o modelo maior da peça de Ésquilo. À mesma conclusão Severyns (1928b, p. 318-320) chega antes de Taplin. Analisando um escólio (DINDORFIUS) ao verso 70 do canto VIII e escólios (DINDORFIUS e MAASS)

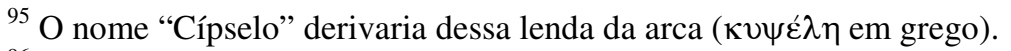

${ }^{96}$ RADT, 1985, p. 114, 236-239, 374-377. TAPLIN, 1977, p. 422-423, 431-433.
} 
ao verso 209 do canto XXII da Ilíada e ainda citando representações do episódio nas artes figurativas $^{97}$, ele apresenta uma reconstituição da psychosthasia segundo o Etíope (ressaltando se tratar de uma conjectura), a qual seria inspirada no episódio homérico do peso das $\kappa \hat{p} \rho \varepsilon$ de Aquiles e Heitor: por ocasião do combate entre Aquiles e Mêmnon, Tétis e Eos vão ao Olimpo implorar a Zeus pela vida de seus filhos; para resolver a questão, Zeus concebe o peso

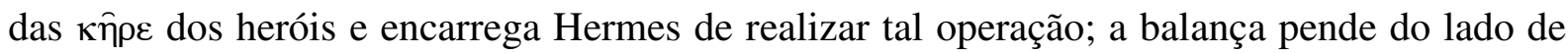
Mêmnon, que é morto por Aquiles; Eos consegue de Zeus ao menos a imortalidade para seu filho e parte carregando o corpo deste.

Diante dessas referências e do paralelo exibido, Mêmnon aflora como o grande rival de Aquiles após a morte de Heitor. A importância desse herói e do Etíope deve muito ao episódio da morte do pelida, ou seja, a magnitude de Aquiles engrandece o herói e o épico que se relacionam diretamente com sua morte. Por que então o Etíope não nos chegou? Por que Mêmnon não encontra destaque em obras antigas gregas ou latinas que nos chegaram?

\section{Pequena Ilíada}

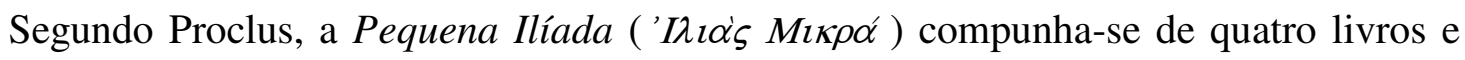
era atribuída a Lesques de Pirra (ou de Mitilene - ambas em Lesbos). Severyns (1928b, p. 314), Jouan (1966, p. 26-27), West (2003a, p. 16) e Debiasi (2004, p. 131) situam a composição do poema no século VII a. C., com os três últimos fornecendo mais precisões: Jouan entre 700 e 680 a. C.; West, por volta do terceiro quarto desse século; Debiasi posiciona o floruit de Lesques em 658/7 a. C.

A Vida de Homero (16) do Pseudo-Heródoto ${ }^{98}$ conserva os supostos versos iniciais desse épico: "I I "Apๆos. À diferença das aberturas dos poemas homéricos, nas quais o canto emana de uma divindade, aqui o próprio poeta toma posse de sua arte e da inspiração de sua obra ( $\alpha \varepsilon i ́ \delta \omega)$. A estruturação do primeiro verso (com o objeto direto e em seguida o verbo em primeira pessoa) lembra a do começo de um poema cíclico recriminado por Horácio: Fortunam Priami cantabo et nobile bellum (Arte Poética, v. 137) ${ }^{99}$.

\footnotetext{
${ }^{97}$ Cf. ROBERT, 1923, p. 1181, n. 3.

${ }^{98}$ Edição de WEST (2003b) = fr. $1 \mathrm{D}$ e W.

${ }^{99}$ Essa estrutura nos remete ainda ao verso inicial da Eneida: Arma uirumque cano. A esse respeito, consultar o artigo de Kopff (1981, p. 924, 927-928).
} 
No sumário de Proclus, dando continuidade ao Etíope, a epopéia principiaria com a disputa pelas armas de Aquiles por Ájax e Odisseu.

Nestor recomenda que alguns gregos se aproximem dos muros de Tróia para tentar descobrir o que se pensa de Ájax e Odisseu. Os enviados ouvem uma discussão entre duas jovens exatamente a respeito do valor dos dois guerreiros: a primeira assegura ser Ájax o mais valoroso, porque transportou o corpo de Aquiles para o acampamento grego, o que Odisseu não conseguiria; a outra, inspirada por Atena, retruca dizendo que até uma mulher seria capaz de carregar um homem desde que alguém o colocasse sobre seus ombros, porém uma mulher não poderia proteger Ájax dos outros guerreiros como o fez Odisseu. Esse debate decide a questão em favor de Odisseu ${ }^{100}$.

Tendo perdido tais armas, Ájax enlouquece, ataca violentamente os animais dos gregos e acaba se suicidando ${ }^{101}$.

Zangado com essa atitude, Agamêmnon não permite que o corpo de Ájax seja cremado. Em conseqüência, esse herói torna-se o único dos que pereceram em Tróia a ser inumado ${ }^{102}$, recebendo um sepulcro no Reteu.

Retomando a guerra, Odisseu captura Heleno em uma emboscada; e o adivinho revela aos gregos os fata para a tomada da cidade. Seguindo revelações de Heleno, Diomedes traz Filoctetes de Lemnos ${ }^{103}$. Curado por Macáon ${ }^{104}$, filho de Asclépio, Filoctetes mata Páris em um grande combate.

Ao ver o príncipe troiano morto, Menelau extravasa toda sua cólera mutilando o cadáver. Esse suplício, todavia, logo termina, pois os troianos conseguem recuperar o corpo de Páris e mais tarde lhe concedem honras fúnebres.

${ }^{100}$ Escólio (BLAYDES) ao verso 1056 da peça Os Cavaleiros, de Aristófanes = fr. 2 D e W. Há outras versões para esse julgamento: na Odisséia (XI, v. 547 - possível interpolação), os juízes são filhas dos troianos (cativas) e Palas Atena - no escólio (DINDORFIUS) a esse verso, conta-se que os gregos consultaram os prisioneiros troianos a respeito da questão (Davies (1989a, p. 60) acredita que essa seria a versão do Etíope); na oitava Neméia de Píndaro, os gregos decidem a questão através de um voto secreto.

${ }^{101}$ Segundo Apolodoro (Epítome, 5, 6-7), Ájax preparava-se para fazer um ataque noturno aos gregos quando Atena o enlouqueceu e desviou o ataque para os animais, que ele trucidou acreditando serem os gregos; depois, caindo em si, suicidou-se.

102 PORFÍRIO, Paralipomena, fr. 4 SCHRADER, apud EUSTÁCIO 285, 34-35 (VAN DER VALK) = fr. 3 D e $\mathrm{W}$.

${ }^{103}$ Apolodoro (Epítome, 5, 8-11) apresenta uma versão diferente: Calcante profetiza a necessidade do arco e das flechas de Héracles (Odisseu e Diomedes vão a Lemnos); depois da morte de Páris, Heleno e Deífobo disputam Helena; sendo este o vencedor, Heleno retira-se da cidade e vai morar no monte Ida; Calcante revela que Heleno conhece os oráculos protetores de Tróia; então Odisseu arma uma emboscada e o prende; Heleno é obrigado a revelar os seguintes meios para capturar a cidade: a recuperação dos ossos de Pélops, a agregação de Neoptólemo ao exército e o roubo do Paládio. Sérvio (ad Aen., II, v. 166) também refere a versão de Apolodoro); e Severyns (1928b, p. 337) julga essa versão corresponder à da Pequena Ilíada.

${ }^{104}$ Em Apolodoro (Epítome, 5, 8), é Podalírio quem cura Filoctetes, uma vez que nesta obra Macáon foi morto por Pentesiléia (Epítome, 5, 1) - para Severyns (1928b, p. 317 e 333), Apolodoro segue o Etíope quanto à morte de Macáon. No Posthoméricas (VI, v. 390-435), também é Eurípilo quem mata Macáon, o qual, ao morrer, como 
Morto Páris, Helena é tomada como esposa por Deífobo ${ }^{105}$.

Em seguida, Odisseu traz Neoptólemo de Ciros ${ }^{106}$ e lhe entrega as armas de Aquiles. Filiado ao exército e de posse dessas armas, Neoptólemo recebe a visita do fantasma de seu pai.

Os acontecimentos da incorporação de Neoptólemo dão azo à evocação da passagem de Aquiles por Ciros: ao deixarem a Mísia, os gregos foram surpreendidos por uma tempestade, e Aquiles foi levado à ilha de Licomedes, onde ocorreu sua união com Deidâmia e a concepção de Neoptólemo ${ }^{107}$.

As armas de Aquiles deveriam receber um tratamento abrangente no poema, em especial a peculiar lança de ponta bifurcada, sobre a qual nos falam dois escólios: um ao verso 142 do canto XVI da Ilíada (MAASS) e um ao verso 68b da sexta Neméia de Píndaro ${ }^{108}$ (DRACHMANN). Para Severyns (1928b, p. 342), o fantasma de Aquiles surgiria justamente para ensinar ao filho o segredo do manejo dessas armas.

De um lado, Neoptólemo integra-se ao exército grego; de outro, Eurípilo, o filho de Télefo e Astíoque, irmã de Príamo, chega em auxílio de Ílion trazendo um exército de Mísios. A bravura de Eurípilo e de seus guerreiros proporciona aos troianos o domínio do campo de batalha; em meio à sua aristia, Eurípilo mata Macáon ${ }^{109}$. Suas façanhas findam, no entanto, quando enfrenta Neoptólemo, que o mata ${ }^{110}$. Sem seu recém-chegado defensor, os troianos refugiam-se no interior da cidade.

Heitor, profetiza o fim próximo de seu algoz. Nas considerações de Severyns (1928b, p. 317 e passim), tais diferenças revelariam o quanto os autores se esforçavam para renovar lendas já abordadas antes.

${ }^{105}$ Essa idéia encontraria eco no verso 276 do canto IV da Odisséia, considerado, porém, uma interpolação.

${ }^{106}$ Uma segunda revelação de Heleno.

${ }^{107}$ Escólio (MAASS) à Ilíada, XIX, v. 326 = fr. 4b D, fr. 4 W. Enquanto nos Cantos Cíprios tal episódio era de ação; aqui seria apenas recordado. Por curiosidade, quantos anos teria o filho de Aquiles ao chegar a Tróia? Apolodoro (Epítome $, 3,18)$ nos fornece informações a esse respeito ao explicar que desde o rapto de Helena até o fim da guerra transcorreram vinte anos: dois desde o rapto até o fim dos preparativos para a primeira expedição, então aconteceu o equívoco na Mísia; daí até se reunirem novamente em Áulis para o início de uma segunda expedição, desfiaram-se mais oito anos. Esse relato de Apolodoro está em acordo com a afirmação de Helena no canto XXIV da Ilíada (v. 765-766) e com a de Agamêmnon no canto II (v. 134). Com base nessas informações, ao chegar a Tróia, Neoptólemo teria por volta de 17 anos segundo a Pequena Ilíada e entre 18 e 19 anos segundo os Cantos Cíprios. Diante desses dados, Severyns (1928b, p. 338) supõe que os Cantos Cíprios, poema mais recente, deveria corrigir uma questão criticada na Pequena Ilíada.

${ }^{108}$ Fr. 5 D e W.

${ }^{109}$ PAUSÂNIAS, III, 26, 9 = fr. 7 D e W.

${ }^{110}$ É interessante notar aqui a tessitura do épico, as relações de causa e consequiência envolvendo Mísia e Ciros, Télefo e Aquiles, Eurípilo e Neoptólemo. A morte de Eurípilo é mencionada na Odisséia (XI, v. 519-521).

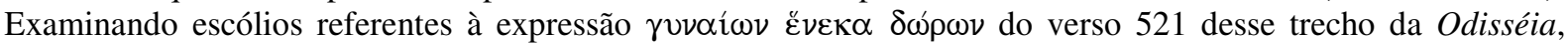
Severyns (1928b, p. 342-346) chega à conclusão de que a Pequena Ilíada deveria fazer menção a um presente oferecido por Príamo a Astíoque para que esta permitisse o auxílio do filho aos troianos, tal presente seria o cacho de ouro ofertado por Zeus a Trós em troca de Ganimedes. 
Os gregos então imaginam uma forma de penetrar em Ílion. E eis que surge o plano do cavalo de madeira. Seguindo instruções de Atena, Epeu começa a construir a máquina.

Dando seqüência ao estratagema, cabe a Odisseu a missão de fazer um reconhecimento de Ílion; assim, em trajes de mendigo ${ }^{111}$ e desfigurado por ferimentos ${ }^{112}$, chega juntamente com Toas à cidade inimiga. Já dentro dos muros, Odisseu acaba sendo identificado por Helena. Todavia, com seu poder de persuasão, faz com ela concorde com o plano em marcha. Depois desse encontro, mata alguns troianos e consegue retornar aos barcos com a missão cumprida.

Mais tarde, Odisseu e Diomedes penetram em Ílion e roubam o paládio, a estátua protetora da cidade. No retorno ao campo grego, à noite, Odisseu caminha detrás de Diomedes; cobiçando toda a glória da façanha, ergue a espada para matar o companheiro. Porém Diomedes percebe a sombra da lâmina provocada pela luz da lua e impede o golpe; em seguida, para evitar qualquer perigo, obriga Odisseu a marchar na frente e o segue espetando-o com a espada ${ }^{113}$.

Concluído o cavalo, alguns dos principais heróis escondem-se em seu ventre ${ }^{114}$. Os demais queimam o acampamento e partem para a ilha de Tênedos, deixando no local apenas Sínon, incumbido de lhes guiar à noite com o sinal de uma tocha.

Cientes da partida dos gregos, os troianos pensam que a vitória enfim lhes sorri. Encontram o acampamento abandonado e o cavalo de madeira. Decididos a introduzir a máquina na cidade, demolem uma parte do muro e pela abertura fazem-na passar. Depois disso, festejam a suposta vitória.

Entretanto, no meio da noite, sob uma lua brilhante, Sínon cumpre sua tarefa ${ }^{115}$.

${ }^{111}$ Escólio (DINDORFIUS) ao verso 248 do canto IV da Odisséia (= fr. 9 W) - verso de uma passagem em que Helena relata esse episódio (v. 242-264).

${ }^{112}$ No sumário de Proclus, o próprio Odisseu se desfigura (para reforçar o disfarce). No escólio (LEONE) ao verso 780 do poema de Licofron (= fr. $8 \mathrm{D} \mathrm{e} \mathrm{W)}$, Odisseu permite que Toas lhe faça ferimentos.

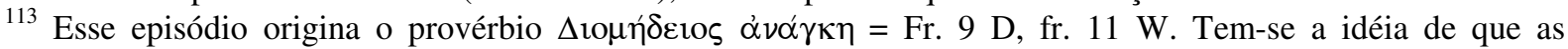
informações colhidas na primeira expedição de Odisseu servem para a execução do roubo do paládio.

${ }^{114}$ Segundo Apolodoro (Epitome, $5,14=$ fr. $10 \mathrm{D}$, fr. $12 \mathrm{~W}$ ), seriam treze os guerreiros no interior do cavalo na Pequena Ilíada - nos códices, o número é três mil; inverossímil, essa quantidade foi "corrigida" para treze. Comentando o episódio, Severyns (1928b, p.352-356) analisa uma passagem de Apolodoro (Epítome, V, 14-15) e uma lista de doze nomes indicados por Eustácio no comentário ao verso 522 do canto XI da Odisséia (Menelau, Diomedes, Filoctetes, Meríones, Neoptólemo, Eurípilo, Eurídamas, Fidipo, Leonteu, Meges, Odisseu e Eumelo); a partir dessa análise, julga o seguinte: o relato de Apolodoro remontaria, em suas grandes linhas, ao do Saque de Îlion, poema que deveria nomear doze guerreiros no interior do cavalo; na Pequena Ilíada, seriam treze, com o acréscimo de Anticlo aos doze indicados no Saque de Ílion; por fim, os versos 285-289 do canto IV da Odisséia, referentes a Anticlo no interior do cavalo e considerados interpolações por Aristarco, viriam da Pequena Ilíada.

${ }^{115}$ Escólio (TZETZES) de Licofron, v. 344 = fr. 11 D, fr. 14 W. Também em Apolodoro (Epitome, 5, 15). 
O episódio da demolição do muro para a entrada do cavalo requer uma atenção especial, pois parece encerrar significados mágico-religiosos e pode constituir uma inovação dessa epopéia (discutida no estudo do Saque de Ílion). W. F. J. Knight (1930, artigo complementado em 1931), investigando esse episódio na Eneida, explora a idéia de o cavalo ter sido concebido (provavelmente desde a Pequena Ilíada) não apenas como um estratagema para introduzir os gregos na cidade inimiga mas também como um instrumento mágico contra o caráter divino do muro de Tróia, um círculo mágico construído por Posídon e Apolo. Assim, ao forçarem os troianos a demolir essa estrutura, os gregos na verdade os teriam forçado a romper a proteção mágica ${ }^{116}$. Aprofundando a questão com base em um estudo de R. S. Conway (1931), Knight (1933) defende a hipótese de tal demolição ter-se dado em uma porta da cidade, a qual precisou ser ampliada (para cima) a fim de que a gigantesca máquina pudesse passar. Essa porta seria a Céia, sob a qual Laomedonte estava sepultado (Sérvio, ad Aen., II, v. 241); com isso, a entrada do cavalo inimigo significaria a profanação de uma passagem sagrada. Knight (1933, p. 260-261) aventa ainda a possibilidade de a escolha da forma de cavalo para a máquina relacionar-se com o vínculo que esse animal tinha com a cidade inimiga, sobretudo através de Laomedonte e Posídon: além da simpatia que essa forma despertaria nos troianos, seria necessário um cavalo para neutralizar a proteção inerente ao muro construído por um deus ligado aos cavalos. Tais idéias reverberariam no último de três fata para o excídio de Tróia enunciados por Plauto na peça Bacchides (v. 953-955): o roubo do paládio, a morte de Troilo e a destruição do limiar superior de uma porta frígia.

Com a sugestão do saque da cidade principiado com a ação de Sínon, finda o casamento possível entre o sumário de Proclus e fragmentos do poema. Outros fragmentos revelam que a Pequena Ilíada comportaria ainda o saque de Tróia e a divisão do butim ${ }^{117}$; os principais provêm de comentários que Pausânias $(X, 25-27,2)$ acresce à descrição de pinturas murais de Polignoto feitas em uma construção dedicada pelos cnídios em Delfos, a qual os habitantes locais chamavam Lesche $(\lambda \dot{\varepsilon} \sigma \chi \eta)$, porque ali costumavam se reunir para conversar. Nessa pintura, as personagens e os eventos relacionados por Pausânias a esse épico são:

- Meges, ferido no braço por Admeto, filho de Áugias, na noite do saque (X, 25, 5);

\footnotetext{
${ }^{116}$ Duckworth retoma esse assunto no artigo "Magical Circles and the Fall of Troy" (1944).

${ }^{117}$ Uma lista (suspeita) de episódios dos Cantos Cíprios e da Pequena Ilíada aparece na Poética de Aristóteles (1459b, 2-7 = Test. D e W); entre os atribuídos à Pequena Ilíada, figura o "saque de Tróia" e "as troianas" (este faria referência ao destino das mulheres na repartição do butim, como na peça As Troianas, de Eurípides).
} 
- ao lado de Meges, vê-se Licomedes, filho de Creonte, também ferido no punho por Agenor (X, 25, 6);

- Etra $^{118}$ e Demofonte, respectivamente a mãe e um filho de Teseu (X, 25, 7) - de acordo com Pausânias $(\mathrm{X}, 25,8)$, eis o relato de Lesques: Etra foge de Tróia na noite do saque e encaminha-se para o campo grego; os filhos de Teseu a reconhecem; Demofonte então pergunta a Agamêmnon se poderia ficar com ela; o rei envia um arauto a Helena para saber-lhe a opinião; Helena consente;

- Andrômaca com o filho ao seu lado, o qual foi arrancado de seus braços - Pausânias (X, 25, 8) atribui a Lesques a seguinte versão da morte de Astíanax: a criança é atirada do alto de uma torre; isso não resulta de uma deliberação dos chefes gregos, mas do desejo de Neoptólemo de matá-lo pessoalmente ${ }^{119}$;

- Deínome, representada junto de uma fonte ao lado de três outras prisioneiras (X, 26, 2);

- Astínoo de joelhos, tendo o corpo atravessado pela espada de Neoptólemo (X, 26, 4);

- Laodice, filha de Príamo e esposa de Helicáon ${ }^{120}$, fillho de Antenor (X, 26, 7) - a respeito dessa imagem, Pausânias $(X, 26,8)$ comenta que, no poema de Lesques, Helicáon, ferido no combate noturno, é reconhecido e salvo por Odisseu ${ }^{121}$;

- os cadáveres de Eioneu, Admeto e Corebo, tendo este último vindo dos confins da Frígia com o intuito de casar-se com Cassandra (X, 27, 1) - segundo Pausânias, Lesques narrava Eioneu morto por Neoptólemo, Admeto por Filoctetes e Corebo por Diomedes (divergindo da versão mais difundida, a qual atribui a morte de Corebo a Neoptólemo);

- os cadáveres de Príamo, Áxion e Agenor (X, 27, 2) - com relação a essas imagens, Pausânias aqui declara que Lesques não reportava a morte de Príamo sobre o altar de Zeus Herceio, mas da seguinte forma: o monarca é arrancado à força desse altar, depois ele se arrasta até a porta de seu palácio, onde encontra Neoptólemo, que o mata sem piedade ${ }^{122}$;

\footnotetext{
${ }^{118}$ No estudo do Saque de Ílion, revela-se como ela foi parar nessa cidade.

${ }^{119}$ Essa versão é confirmada e detalhada por um escólio (TZEZES) ao verso 1268 do poema de Licofron (= fr. 20 D, fr. 29 W): Neoptólemo leva Andômaca para os barcos; quanto a Astíanax, o glorioso filho de Aquiles o arrancou dos braços de sua ama, afastou-o com o pé e em seguida o atirou de uma torre.

${ }^{120}$ Referido na Ilíada (III, v. 122-123).

${ }^{121}$ No estudo dos Cantos Cíprios (episódio da embaixada enviada pelos gregos a Ílion), viu-se que Antenor teria hospedado e salvo dos troianos os embaixadores (supostamente Odisseu e Menelau). Daí a proteção que Odisseu agora confere a Helicáon.

${ }_{122}$ Em um poculum homericum da época helenística (MB 27, apud SINN (1979, p. 94-95), citado junto ao fr. 25 W), figura uma cena semelhante à descrita por Pausânias para a morte de Príamo, com a seguinte inscrição:

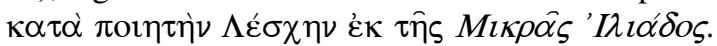


quanto a Áxion e Agenor, na Pequena Ilíada, o primeiro seria filho de Príamo e teria encontrado a morte nas mãos de Eurípilo, filho de Euhémon, o segundo foi morto por Neoptólemo.

Sem que Eurídice figure nas pinturas, Pausânias $(X, 26,1)$ a designa como esposa de Enéias no poema de Lesques e nos Cantos Cíprios.

Além de Pausânias, outras fontes desvelam acontecimentos do poema. Um escólio (DINDORFIUS) ao verso 155 da Lisístrata de Aristófanes ${ }^{123}$ informa que, ao encontrar Helena, Menelau ergueu sua espada para puni-la, mas deixou a arma cair quando lhe viu os seios desnudos. E o referido escólio (TZEZES) ao verso 1268 do poema de Licofron ${ }^{124}$ apresenta ainda supostos versos da Pequena Ilíada relativos à repartição do butim: Neoptólemo recebeu Andrômaca de bela cintura, desejada por todos os chefes, e Enéias, o glorioso filho de Anquises domador de cavalos ${ }^{125}$.

Vários episódios da Pequena Ilíada aparecem na Odisséia: a morte de Ájax sobre as armas de Aquiles (XI, v. 543-564), Deífobo como o último esposo de Helena (IV, v. 276; VIII, v. 517), a luta entre Neoptólemo e Eurípilo (XI, v. 519-521), o ingresso de Odisseu em Tróia disfarçado de mendigo (IV, v. 240-258) e a construção do cavalo de madeira por Epeu (VIII, v. 492-495). Poucos na Ilíada: a história de Filoctetes (II, v. 716-725) e o crescimento de Neoptólemo em Ciros (XIX, v. 326-337).

Refletindo a respeito do conteúdo da Pequena Ilíada, Severyns (1928b, p. 357) acredita que sua composição, mais recente que a do Etíope e a do Saque de Ílion, tenha sido concebida a fim de preencher um vazio deixado entre estes últimos épicos, ou seja, entre a morte de Ájax no final do Etíope e a deliberação sobre o cavalo de madeira no princípio do Saque de Ílion; o poeta, no entanto, considerando exíguo o assunto, teria abordado também o saque da cidade e a divisão do butim.

Outra consideração interessante a respeito do conteúdo desse épico decorre da importância por ele concedida a processos mágico-religiosos. Os oráculos, comuns às epopéias cíclicas, adquirem aqui um relevo ainda maior; e, ao lado deles, há os prováveis contornos mágicos e ritualísticos do episódio do cavalo de madeira, no qual se destaca a

\footnotetext{
${ }^{123}$ Fr. 19 D, fr. $28 \mathrm{~W}$.

${ }^{124}$ Fr. 20 D, fr. 30 W. Todavia, no escólio (SCHWARTZ) ao verso 14 da peça Andrômaca, de Eurípides, esse fragmento é imputado ao Górgona do poeta helenístico Símias.

${ }^{125}$ No escólio ao verso 1232 do poema de Licofron, Tzetzes conta que, no poema de Lesques, Enéias recuperaria a liberdade depois de Orestes matar Neoptólemo em Delfos (fragmento considerado dúbio).
} 
demolição do muro de Tróia. Esse aspecto do poema deve-se em grande parte ao papel do adivinho Heleno; com efeito, o enredo parece ter sido estruturado em função de revelações por ele feitas aos inimigos: resolvida a questão interna das armas de Aquiles, os gregos voltam-se novamente para a tomada de Tróia, cujo passo inicial consiste na captura de Heleno; depois disso, os procedimentos gregos apresentam-se como uma seqüência guiada por revelações desse adivinho. Além da recuperação de Filoctetes e da incorporação de Neoptólemo, (ainda que Proclus não indique) outros dois episódios também se insinuam decorrentes de revelações de Heleno: o roubo do paládio e o embuste do cavalo de madeira, os quais se configuram como passos mágico-religiosos para eliminar proteções mágicoreligiosas de Tróia - como se Heleno tivesse informado aos gregos que a cidade estaria segura enquanto o paládio estivesse em seu interior e enquanto o círculo do muro construído por Posídon e Apolo estivesse fechado. A partir dessas informações, os gregos teriam pensado em uma maneira de eliminar tais proteções, concebendo então as idéias do roubo do paládio e do cavalo de madeira.

A partir dessas reflexões, pode-se imaginar que, na cadeia do ciclo troiano, o tema principal da Pequena Ilíada seria a eliminação das proteções divinas de Tróia, e o que fio condutor dessa trama seriam as revelações de Heleno. Nessa contextura, os fata apresentados por Plauto pertenceriam aos poemas do ciclo troiano: a morte de Troilo aos Cantos Cíprios, o roubo do paládio e quebra do limiar superior de uma porta à Pequena Ilíada.

\section{Saque de Ílion}

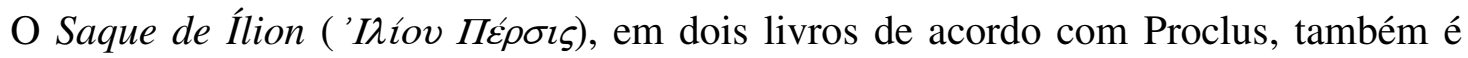
atribuído a Arctino de Mileto; por isso, a data de sua composição aproximar-se-ia da do Etíope, entre o final do século VIII e o começo do VII a. C. - Jouan (1966, p. 26-27) a situa entre 725 e 700 a. C.

No oitavo canto da Odisséia, esboça-se uma pequena versão do saque: ao pedir ao aedo que cante, Odisseu introduz o assunto do cavalo de madeira, de sua confecção por Epeu com o auxílio de Atena e de sua astúcia para introduzi-lo em Tróia (v. 492-495); em seguida, atendendo ao pedido, Demódoco canta um resumo da tomada da cidade (v. 499-520): o atear fogo ao acampamento e a partida dos gregos; a descoberta do cavalo pelos troianos e sua condução para a acrópole; a deliberação acerca do que fazer com o artefato, na qual afloram 
três posições (verificar com lanças de bronze seu interior, atirá-lo de um precipício ou guardálo como oferenda aos deuses); a vitória da terceira posição; a saída dos guerreiros do interior do cavalo, o assalto da cidade; a invasão do palácio de Deífobo por Ulisses e Menelau; uma aristia de Odisseu, secundado por Atena.

Subsistem escassos fragmentos do poema; assim, a reconstituição de seu conteúdo pauta-se principalmente na Chrestomathia de Proclus e na Biblioteca de Apolodoro (Epítome, $5,16-25)$.

Ao encontrar o cavalo de madeira no campo abandonado pelos gregos, os troianos questionam-se sobre o significado de tal engenho e debatem a respeito do que fazer com ele: uns propõem atirá-lo de um precipício, outros atear-lhe fogo; outros, porém, consideram-no um objeto sagrado que deve ser dedicado à deusa Atena ${ }^{126}$. Ao fim, vence a opinião destes últimos. Os troianos então começam a festejar o desaparecimento dos inimigos.

Este começo gera uma dúvida: não se sabe se a deliberação dos troianos ocorria fora ou dentro da cidade. Inicialmente, tem-se a impressão de que o debate acontecia no local onde encontraram o cavalo; contudo, a passagem imediata do final da discussão para as festividades sugere que o cavalo já se encontrasse dentro dos muros, o que coincidiria com a versão apresentada na Odisséia (VIII, 492-520) e na Biblioteca de Apolodoro (Epítome, 5, 16). Além disso, não há qualquer referência à demolição do muro no Saque de Ílion.

Diante dessas dificuldades, Davies (1989a, p. 74) expõe duas possíveis tradições para o episódio: uma consistiria de uma deliberação fora da cidade seguida da demolição do muro para a entrada do animal; a outra, de uma deliberação já no interior da cidade, tendo o cavalo entrado sem a demolição do muro. Se de fato existiam duas versões, a segunda seria a mais antiga, tendo sido adotada na Odisséia e no Saque de Ílion; a Pequena Ilíada, por conseguinte, teria seguido (ou mesmo forjado) uma versão diferente, na qual o episódio da demolição do muro revestia-se de grande importância.

\footnotetext{
${ }^{126} \mathrm{Na}$ Biblioteca de Apolodoro (Epítome, 5, 17), Cassandra anuncia em meio ao debate que o cavalo contém gregos armados, e com ela concorda o vidente Laocoonte - West (2003a, p. 145) atribui esse evento ao Saque de Ílion.
} 
Durante as celebrações, Apolo envia-lhes um sinal funesto: duas serpentes, vindas de ilhas próximas rastejando sobre as águas, lançam-se sobre Laocoonte e um de seus dois filhos e os matam ${ }^{127}$.

Temendo os significados de tal prodígio, Enéias e seus seguidores fogem para o monte Ida ${ }^{128}$.

No canto XX da Ilíada (v. 302-308), anuncia-se a salvação de Enéias: inspirado por Apolo, ele aventura-se a combater Aquiles; preocupado com a sorte do herói, Posídon alega aos imortais que o destino de Enéias é sobreviver, para que a raça de Dárdano não pereça, e um dia reinar sobre os troianos.

Examinando os fragmentos desse épico, Davies (1989a, p. 74-75) comenta a importância concedida a Laocoonte por autores posteriores ${ }^{129}$ e retoma uma interpretação alegórica da morte do sacerdote e da fuga de Enéias (ressaltando, todavia, não ser possível saber qual a significação real desses eventos na trama do poema): as duas serpentes representariam Agamêmnon e Menelau; Laocoonte simbolizaria Tróia, e seu filho mais velho a morte de Príamo (filho mais velho de Laomedonte); a sobrevivência do filho mais novo faria menção à fuga de Enéias ${ }^{130}$. Quanto ao caso específico de Enéias, o episódio faz pensar em uma permanência dele e dos seus na região do monte Ida após a guerra, onde assumiria o governo dos troianos - como indicado no canto XX da Ilíada e ainda na Teogonia (v. 1010) ${ }^{131}$.

A esse respeito, Debiasi (2004, p. 137-139) tece uma análise significativa para nossa tese. Um dos temas principais do Saque de Ílion seria a querela manifesta na Ilíada (XIII, v. 460-461 e XX, v. 178-183) entre os dois ramos descendentes de Dárdano: o de Ilo, que rege a cidade e é representado especialmente por Príamo e Heitor; o de Assáraco, relegado a um segundo plano e representado por Anquises e Enéias. Essa disputa teria vindo à tona no

\footnotetext{
${ }^{127}$ A idéia de que as serpentes seriam um sinal de Apolo é expressa por Apolodoro (Epítome, 5, 18). Os nomes delas seriam Porcete e Caribéia (escólio (TZETZES) de Licofron, v. 347; Sérvio, ad Aen., II, v. 211).

${ }^{128}$ Apolodoro (Epítome, 5, 21) posiciona a fuga de Enéias mais tarde (após Neoptólemo matar Príamo e Menelau e Odisseu salvarem Glauco, filho de Antenor), com Anquises sobre os ombros, e informa que os gregos o deixaram partir em respeito por sua $\varepsilon \dot{\sigma} \sigma \varepsilon ́ \beta \varepsilon 1 \alpha$. Debiasi (2004, p. 180) ressalta a diferença do destino de Enéias existente entre essa versão e a da Pequena Ilíada, em que ele é preso e dado a Neoptólemo.

${ }^{129}$ Davies destaca Sófocles, autor de uma peça (perdida) intitulada Laocoonte (RADT, fr. 370-377).

${ }^{130}$ Já presente em Robert (1881, p. 192) e em Monro (1884, p. 30), essa interpretação é também discutida por Anderson (1997, p. 67).

${ }^{131}$ A mesma promessa do reinado de Enéias é feita por Afrodite a Anquises no Hino Homérico a Afrodite (I) (v. 196-197), poema provavelmente posterior ao Saque de Ílion.
} 
episódio do debate quanto ao que fazer com o cavalo de madeira: Enéias e os seus teriam tomado o partido daqueles que defendiam a destruição do cavalo (como Cassandra e Laocoonte). E, de acordo com o sumário de Proclus, a fuga de Enéias decorria da morte de

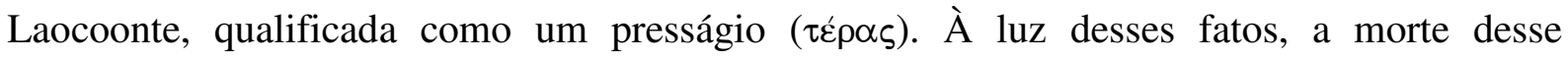
sacerdote poderia também ser vista como um sinal ( $\sigma \eta \mu \varepsilon i ̂ v$, como aparece em Apolodoro) enviado por Apolo a Enéias, para que este pudesse salvar-se - em acordo com o anúncio do canto XX da Ilíada. Quanto à referida interpretação alegórica desses acontecimentos conexos, Debiasi, antes de abordá-la, comenta um paralelo entre este prodígio das serpentes e aquele das serpentes e dos pássaros interpretado por Calcante na Ilíada (II, v. 308-329); em seguida, desfia dois significados para o prodígio no Saque de Ílion: para os troianos, a vinda das serpentes significaria o retorno dos gregos, com os dois monstros provavelmente simbolizando os atridas; para Enéias, além desse significado, os dois filhos de Laocoonte representariam os dois ramos dos descendentes de Dárdano, o mais velho, morto pelas serpentes, aludindo ao de Ilo, destinado a extinguir-se, e o filho mais novo, sobrevivente, aludindo ao ramo de Assáraco, destinado a sobreviver e reinar sobre troianos.

Voltando ao sumário de Proclus, vemos Enéias encaminhar-se para o Ida ao deixar a cidade. Seria esse seu destino final no poema? Fontes atestam viagens de Enéias após a queda de Tróia (as quais adquirem sua forma mais desenvolvida na Eneida). Smith (1981, p. 32-33) estuda o fr. 373 (RADT) do Laocoonte de Sófocles (RADT, fr. 370-377) e conclui que o tragediógrafo, assim como ocorre no Saque de Ílion, faz Enéias, sob a orientação de Anquises, sair de Tróia logo após o prodígio das serpentes, antes da tomada da cidade. Inspirando-se em uma informação veiculada por Ateneu (Deipnosophistae, VII, 277e), segundo a qual Sófocles apreciava os poemas do ciclo e teria mesmo composto peças inteiras seguindo as histórias neles narradas, Debiasi (2004, p. 136-146) compara fragmentos do Laocoonte com fragmentos do Saque de Ílion e levanta a hipótese de que o autor dessa epopéia pode ter sido o primeiro a abordar a viagem de Enéias ao Ocidente - na verdade, para ele, o Saque de Ílion e, inspirado neste, a Pequena Ilíada abordariam as viagens de Enéias.

Tais leituras evidenciam o relevo concedido a Enéias nessa epopéia. E esse herói também recebia destaque no outro épico do ciclo troiano atribuído a Arctino, o Etíope, no episódio da luta pelo corpo de Aquiles. 
Prosseguindo com o plano de invasão, Sínon consegue penetrar em Ílion com seu fingimento e, no momento adequado, faz sinal com uma tocha para os gregos, que retornam de Tênedos. Adormecidos os troianos, os guerreiros saem do ventre do imenso $^{132}$ cavalo com suas armas e favorecem a entrada do exército. Começa então o massacre, os gregos caem sobre os inimigos, enviam muitos à morte e dominam a cidade.

Tentando escapar, Príamo refugia-se junto do altar de Zeus Herceio, mas Neoptólemo o mata.

Menelau encontra Helena e Deífobo, mata este e a conduz aos barcos ${ }^{133}$.

Ájax, filho de Oileu, persegue Cassandra, que se agarra a uma estátua de madeira da deusa Atena. Ele, no entanto, a arrasta, usando de tamanha violência que acaba arrancando a imagem de seu altar. Os gregos temem tal sacrilégio, execram essa atitude e decidem lapidá-lo. Ele, todavia, se salva do perigo abrigando-se no altar de Atena... Mais tarde, quando os gregos navegarem para casa, a deusa há de lançar-lhe a morte em pleno mar $^{134}$.

Odisseu executa Astíanax.

Vencido o inimigo, ocorre a divisão do butim. Neoptólemo recebe Andrômaca como prêmio. Demofonte e Acamante, filhos de Teseu, que haviam encontrado Etra, sua avó, levam-na com eles ${ }^{135}$.

Repartido o butim, os gregos ateiam fogo à cidade e imolam Polixena sobre o túmulo de Aquiles.

\footnotetext{
${ }^{132}$ A dimensão gigantesca do cavalo manifesta-se na Biblioteca de Apolodoro (Epítome, 5, 20) ao lermos que Equíon, filho de Porteu, salta antes de todos e acaba perdendo a vida na queda e que os demais descem por uma corda - West (2003a, p. 145) atribui esse conteúdo ao Saque de Ílion. A Eneida também expressa tal dimensão: instar montis equum (II, v. 15). Um escólio (Monacense lat. 18059, do século XI, in: TIMPANARO, 1978, p. 429-457) ao referido verso da Eneida (= fr. 2 D, fr. 1 W) assinala que Arctino definia o cavalo com 100 pés de comprimento e 50 de largura e capaz de mover a cauda e os joelhos. Sérvio (ad Aen., II, v. 150) diz que ele teria 120 pés de comprimento e 30 de largura e que ainda seria capaz de mover a cauda, os joelhos e os olhos.

133 A maior parte dos episódios expostos até este ponto aparece no terceiro canto de Demódoco na corte do rei Alcino (Odisséia, VIII, v. 499-520), com algumas diferenças; cotejaremos essa passagem da Odisséia, a Pequena Ilíada, o Saque de Ílion e o canto II da Eneida no terceiro capítulo.

${ }^{134}$ Eis um trecho complexo. Três hipóteses principais podem ser levantadas para essa estranha inserção de um evento futuro no meio dos acontecimentos do saque: na primeira, o poema de fato anteciparia o relato dessa morte e depois retornaria aos episódios do saque; na segunda, o poema faria apenas uma alusão a um fato futuro (pertencente com mais propriedade à temática dos retornos); na terceira, tal inserção constituiria uma interpolação. Debiasi (2004, p. 137) discute a questão e defende a primeira hipótese, argumentando que isso estaria em acordo com uma propensão dos poemas cíclicos para se desviar do tempo da narração, ora para o passado, ora para o futuro.

${ }^{135}$ Ilíada, III, v. 143-144. Apolodoro (Epítome, 1, 23) relata que Etra foi capturada em Atenas pelos Dióscuros quando eles resgatavam Helena, raptada por Teseu. Um escólio (SCHWARTZ) ao verso 31 da peça As Troianas, de Eurípides, informa que no Saque de Ílion os filhos de Teseu teriam recebido outros prêmios além de Etra (nas Eumênides (v. 397-402), de Ésquilo, eles recebem terras, das quais oferecem a Atena uma parte às margens do rio Escamandro, que corresponderia ao promontório do Sigeu, na entrada do Helesponto, onde a deusa possuía um santuário).
} 
Quanto à morte de Astíanax, um escólio (SCHWARTZ) ao verso 10 da Andrômaca de Eurípides $^{136}$ ensina que no Saque de Ílion a criança é atirada de uma muralha, mas não fornece o autor de tal ato. Confrontando uma informação de Pausânias $(X, 25,9)^{137}$ com o texto de Proclus, Severyns (1928b, p. 367) estima que nesse épico os gregos teriam deliberado sobre a morte de Astíanax, cuja execução teria sido delegada a Odisseu; assim, esse ato revestir-se-ia aqui de um caráter menos brutal do que na Pequena Ilíada - isso corresponde à versão de Eurípides (Troianas, v. 719-739, 1133-1135; Andrômaca, v. 8-11). Apolodoro (Epítome, 5, 23), aparentemente seguindo essa tradição, posiciona essa morte em meio aos sacrifícios aos deuses e à imolação de Polixena. Esse episódio relacionar-se-ia ainda com a hipótese do Debiasi segundo a qual o Saque de Ílion exploraria a querela entre os dois ramos descendentes de Dárdano: a morte de Astíanax marcaria o fim da descendência de Heitor e da sucessão natural de Príamo no governo da cidade.

Três fragmentos subsistem vinculados a esse épico.

Um escólio (MAASS) ao verso 515 do canto XI da Ilíada ${ }^{138}$ indica a participação dos irmãos “médicos” Macáon e Podalírio no Saque de Ílion, no qual apareceriam como filhos de Posídon $^{139}$ : esse deus teria concedido ao primeiro o dom da cirurgia e ao segundo o do diagnóstico (atributo que lhe teria permitido detectar a loucura de Ájax antes de todos). Estudando a questão, Severyns (1928b, p. 358-361) pensa que o poema deveria abordar um episódio com Podalírio e nesta ocasião apenas se referir a Macáon, já morto (por Pentesiléia no Etíope - por Eurípilo na Pequena Ilíada).

West (2003a, p. 150, fr. 5*) liga a esse épico o relato de um escólio (DINDORFIUS) ao verso 486a do canto XVIII da Ilíada, atribuído aos poetas cíclicos: Electra, transformada em estrela e integrada à constelação das Plêiades, abandona seu lugar no céu para não ver o saque de Tróia, cidade de seus descendentes, sendo ela mãe de Dárdano.

Por fim, concedamos uma atenção especial a um fragmento considerado suspeito ${ }^{140}$. Segundo Dionísio de Halicarnasso (Antigüidades Romanas, I, 69, 3), Arctino contava que o paládio verdadeiro, dado por Zeus a Dárdano, permanecia em Tróia, em um lugar protegido, enquanto a cidade estava sendo tomada pelos gregos, os quais teriam roubado anteriormente

\footnotetext{
${ }^{136}$ Fr. 3 D e W.

${ }^{137}$ Fr. $21 \mathrm{D}$, fr. $18 \mathrm{~W}$ da Pequena Ilíada.

${ }^{138}$ Fr. $1 \mathrm{D}$, fr. $2 \mathrm{~W}$.

${ }^{139}$ São filhos de Asclépio na versão mais corrente.

${ }^{140}$ Fr. 4 W - fragmentum dubium para Davies (1988, p. 65-66).
} 
uma cópia que ficava exposta ao público. Ao longo dos capítulos 68 e 69 do livro I, fundamentando-se em fontes diversas (entre as quais o historiador Calístratos, o mitógrafo Sátiros e o poeta Arctino), Dionísio relata a história do paládio: sua concessão por Atena à esposa de Dárdano, o oráculo que pregava a inexpugnabilidade da cidade enquanto Dárdano nela guardasse e cultuasse esse objeto sagrado; a história da falsa estátua roubada pelos gregos e a condução da verdadeira por Enéias ao Lácio juntamente com os Penates, objetos sagrados que ficavam guardados no templo de Vesta.

Horsfall (1979, p. 374-375) e Davies (1989a, p. 79) salientam uma aparente contradição no relato de Dionísio de Halicarnasso: segundo o oráculo, a cidade seria inexpugnável enquanto o paládio estivesse em seu interior; em seguida, informa que o paládio verdadeiro ainda se encontrava na cidade enquanto os gregos a saqueavam. Nessa mesma linha de pensamento, Smith (1981, p. 27) supõe que a história do falso Paládio não provinha especificamente de Arctino, mas de outra fonte usada por Dionísio para compor esse relato; para ele, seria confiável apenas a informação de que, segundo Arctino, Zeus teria dado o Paládio a Dárdano.

Discordando da maioria, Debiasi (2004) concede mais crédito ao testemunho de Dionísio de Halicarnasso ao estudar com profundidade o assunto ("Enea con il Paladio in Italia”, p. 146-155): a suposta contradição entre a tomada da cidade e a permanência do paládio em seu interior desfaz-se ao se levar em conta a partida de Enéias logo após a morte de Laocoonte, ou seja, antes de os gregos saírem do cavalo e possibilitarem a invasão propriamente dita da cidade - de fato, quando Enéias deixa Tróia, os troianos ainda se julgam vencedores.

Sem entrar no mérito de uma falsa estatueta, Severyns (1928b, p. 351) estima que a seguinte versão do roubo do paládio fizesse parte desse poema (semelhante à apresentada por Apolodoro (Epítome, 5, 13), excetuando-se a história do disfarce de mendigo): Odisseu vai com Diomedes a Tróia; este fica vigiando enquanto aquele entra na cidade; reconhecido por Helena, Odisseu rouba o Paládio com a ajuda desta; em seguida, mata vários guardas, reencontra Diomedes e, com o auxílio deste, leva aos barcos o espólio.

Se levarmos em consideração o princípio do poema indicado por Proclus, a descoberta do cavalo no acampamento grego, seria estranho que o roubo do paládio fizesse parte de seu enredo, a não ser em forma de recordação. Na seqüência do ciclo, este seria o épico do saque 
propriamente dito, de ação guerreira (como o Etíope, supostamente do mesmo autor), sem tantas recorrências a processos mágico-religiosos.

Para concluir o estudo desse poema, retomemos a passagem da Odisséia que aborda o saque de Tróia (VIII, v. 492-520). Após o estudo da Pequena Ilíada e do Saque de Ílion, constatamos que esses épicos desenvolvem uma temática que já se encontra em embrião na Odisséia. Nessa linha de pensamento, é interessante observar que o poema homérico também já expõe os eventos do saque divididos em duas partes e que os episódios da primeira integram a Pequena Ilíada e o teor da segunda aproxima-se do conteúdo do Saque de Ílion. Enfim, pouco depois de ouvir o canto da tomada da cidade troiana, Odisseu narra à corte de

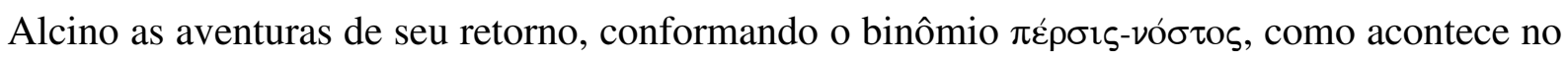
desenrolar do ciclo troiano.

\section{Retornos}

A temática dos retornos dos gregos que lutaram em Tróia abrange histórias célebres, como a do castigo de Ájax, filho de Oileu, mencionada no Saque de Ílion, a das aventuras de Odisseu até regressar a Ítaca e recuperar seu poder na cidade, tema da Odisséia, a do retorno

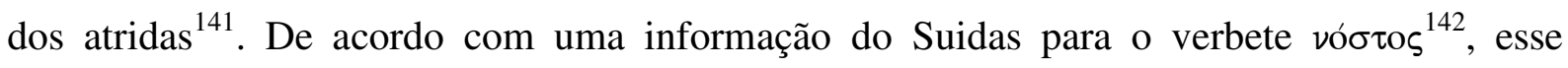
manancial deve ter ensejado a composição de vários poemas; e a Odisséia corrobora a popularidade do assunto: na casa de Odisseu, o aedo Fêmio canta a volta dos gregos (' A $\chi \alpha 1 \hat{\omega} v$

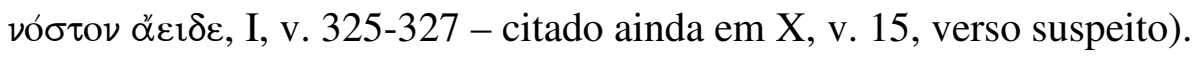

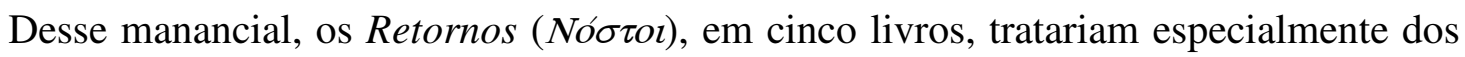
atridas e de Neoptólemo. O poema é atribuído a Ágias de Trezene, poeta que, segundo Debiasi (2004, p. 229-230), seria provavelmente o último e o mais sistemático de muitos poetas que desenvolveram essa temática. Quanto à data de sua composição, Jouan (1966, p. 26-27) a situa entre 650 e 625 a. C.

De acordo com o sumário de Proclus, a epopéia principiaria com debates acerca da volta para casa.

\footnotetext{
${ }^{141}$ Aliás, Ateneu cita um épico intitulado Retorno dos Atridas em dois fragmentos: um sobre Tântalo, difícil de conciliar com o relato de Proclus e provavelmente ligado a uma descida aos infernos (Deipnosophistae, 281b = fr. 9 D, fr. $3 \mathrm{~W}$ ), abordada mais tarde; outro sobre Hermioneu (Deipnosophistae, 399a = fr. 8 D, fr. $12 \mathrm{~W}$ ). West (2003a, p. 17) acredita que tal poema seja o mesmo Retornos. Davies (1989a, p. 85), porém, prefere a cautela, imaginando que talvez se trate de outro poema.

${ }^{142}$ Test. D e W.
} 
Findada a guerra, os gregos desejam rever suas pátrias. Nesse momento, Atena, tomada de ira pelos sacrilégios, sobretudo o do Ájax lócrio, semeia a contenda entre os atridas a respeito da viagem de volta. Agamêmnon resolve aguardar mais tempo em Ílion para tentar aplacar a ira da deusa. Diomedes e Nestor zarpam e em segurança retornam às suas terras. Depois, é a vez de Menelau partir; em alto mar, é açoitado por uma tempestade, perde membros de sua frota e acaba aportando no Egito com apenas cinco embarcações ${ }^{143}$. Um grupo de gregos liderado por Calcante, Leonteu e Polipetes segue a pé na direção de Cólofon, onde Calcante morre e é sepultado ${ }^{144}$.

Agamêmnon enfim decide deixar Ílion. Os homens que o seguem então iniciam os preparativos para a viagem; nesta ocasião, o fantasma de Aquiles lhes aparece e tenta preveni-los do que está por vir. Quando tudo fica pronto, Agamêmnon realiza um sacrifício para Atena e em seguida zarpa, chegando a Tênedos.

Nessa ilha, Neoptólemo, que acompanha Agamêmnon, recebe a visita de Tétis, que o convence a não prosseguir com os demais, a esperar dois dias e realizar sacrifícios. Ele assim o faz.

A frota liderada por Agamêmnon deixa Tênedos; perto de Tenos, é surpreendida por uma tempestade enviada por Zeus, atendendo a um pedido de Atena. Em meio a essa intempérie, muitos barcos afundam. Mais tarde, a frota defronta outra tormenta junto às

\footnotetext{
${ }^{143}$ No canto III da Odisséia, Nestor conta a Telêmaco a disputa entre os atridas (v. 133-152), a sua viagem e a de Diomedes (v. 153-183) e depois a de Menelau (v. 276-312). Quanto à disputa, Nestor informa que Menelau defendia uma partida imediata, enquanto Agamêmnon pregava a realização de sacrifícios até que Atena fosse apaziguada; desse desentendimento, dois grupos se formaram, a metade da armada ficou com Agamêmnon para cumprir sacrifícios a Atena; a outra metade seguiu Menelau para Tênedos logo na manhã seguinte; nessa ilha, houve outro desentendimento, e a parte que acompanhava Menelau se separou. Apoiando-se no relato de Apolodoro (Epítome, 5, 23), em sua análise do Saque de Ílion e nesse relato da Odisséia, Severyns (1928b, p. 371) supõe que nos Retornos a ira de Atena diria respeito exclusivamente ao sacrilégio de Ajax lócrio.

${ }^{144}$ Davies (1989a, p. 81) comenta que a viagem a pé, mais segura, deve ter sido sugerida por Calcante, sabedor da ira de Atena. O sumário de Proclus indica estranhamente a morte de Tirésias; Apolodoro (Epítome, 6, 2-4) conta que Calcante morre em Cólofon (fato mais lógico), confirmando um oráculo que previa seu fim ao encontrar um adivinho mais sábio do que ele: nessa cidade, ele defronta Mopso, filho de Apolo e Manto, sendo esta a filha de Tirésias; os dois realizam um duelo de adivinhações, vencido por Mopso; Calcante falece de desespero. A alusão a Tirésias relaciona-se com episódios do ciclo tebano, sobretudo do poema Epígonos, que abordaria a morte de Tirésias em Tilfusa durante a fuga dos tebanos derrotados pelos epígonos. Segundo um escólio (KEIL) ao verso 308 do canto I das Argonáuticas de Apolônio de Rodes, no poema Epígonos (o fragmento cita a Tebaída, o que é considerado um engano), a filha desse adivinho, Manto, capturada pelos epígonos, foi oferecida ao oráculo de Apolo em Delfos; lá, obedecendo a um oráculo de deus, que dizia entre outras coisas que ela deveria se casar com o primeiro homem que encontrasse, casa-se com o cretense Rácio, filho de Lebes; em seguida, foram para Cólofon, na Ásia Menor, onde Manto ficou célebre por lamentar o saque de sua antiga cidade e fundar um santuário de Apolo.

145 As rochas Caféridas situam-se no promontório meridional da Eubéia. Na Odisséia (IV, 492-511), Proteu conta a Menelau o episódio da morte do Ájax lócrio.

${ }^{146}$ Como o grupo de Calcante, para evitar os efeitos da ira de Atena. Sérvio (ad Aen., II, v. 166) atribui o aviso a Heleno; em outro ponto (ad Aen., III, v. 297), comenta que Neoptólemo, grato, deixa Andrômaca de herança ao troiano.
} 
rochas caféridas, durante a qual o Ájax lócrio encontra a morte ${ }^{145}$. Tétis prepara seu corpo e the rende honras fúnebres na ilha Miconos.

Quanto a Neoptólemo, seguindo sempre as instruções de Tétis, decide também seguir por terra ${ }^{146}$. Na região da Trácia, encontra Odisseu em Maronéia, país dos Cícones. Em seguida, continua sua jornada, ao longo da qual perde Fênix. Após render as devidas honras fúnebres ao falecido, prossegue e alcança à terra dos molossos, no Epiro. Depois, Peleu o reconhece.

Termina nesse ponto o relato referente ao retorno de Neoptólemo no sumário de Proclus. Estudando a questão, Severyns (1928b, p. 381-384) depreende um esforço do autor dos Retornos para preencher uma lacuna existente entre a situação de Neoptólemo ao fim do saque e a apresentada no canto IV da Odisséia (o herói casando-se com Hermíone e a conduzindo à Tessália, onde reina, sucedendo a Peleu). Servindo-se das informações de Proclus e de Apolodoro (Epítome, 6, 5 e 12-13), propõe uma reconstituição dos eventos contidos nessa lacuna: Neoptólemo atende ao pedido de Tétis em Tênedos; depois vai à Trácia, onde queima seus navios; continua a pé com a tropa dos mirmidões, o adivinho Heleno e Andrômaca; após encontrar Odisseu, segue sem passar pela Tessália; perde Fênix e enfim chega ao Epiro, onde domina os molossos e destes se torna o governante; mais tarde, agora um rei, apresenta-se a Peleu, na Ftia, onde o avô o reconhece. Depois desse ensaio de reconstituição, Severyns evoca um escólio (DINDORFIUS) ao verso 188 do canto III da Odisséia, texto que traz à tona um oráculo revelado por Heleno segundo o qual Neoptólemo deveria estabelecer-se onde encontrasse uma casa com fundações de ferro, paredes de madeira e teto de lã. Chegando ao lago Pambotis, no Epiro, perto de Dodona, encontra um acampamento cujas tendas eram feitas com lanças fincadas no chão, sobre as quais se estendidem mantos de lã; compreendendo que nesse lugar o oráculo se concretiza, toma a região pela força e nela tem de Andrômaca um filho, Molosso, do qual deriva o nome dos habitantes da região. Recorrendo ainda a Pausânias (I, 11, 1), para o qual Neoptólemo instalou-se no Epiro em função do oráculo revelado por Heleno, Severyns acredita que tal oráculo faria parte dos Retornos e designaria a razão pela qual Neoptólemo teria evitado a viagem direta para a Ftia: o herói deveria procurar um local com as características vaticinadas por Heleno. 
Clitemnestra ${ }^{147}$.

Mais tarde, Orestes e Pílades chegam para vingar o assassínio de Agamêmnon ${ }^{148}$.

Enfim, narra-se o retorno de Menelau ao seu reino ${ }^{149}$.

Quanto à vingança de Orestes, Severyns (1928b, p. 405-408) acredita que essa epopéia relataria a história do herói retornando da Fócida, onde havia sido educado por Estrófio, pai de Pílades ${ }^{150}$.

Náuplio e seus filhos, Palamedes, Éax e Nausimedonte, deveriam participar dos Retornos nos episódios da morte de Agamêmnon, como insinua Apolodoro (II, 1, $5^{151}$ ); depois, no Epítome (6, 7-11), conta-se que Náuplio, assim que sabe da morte de Palamedes ${ }^{152}$, vai ao encontro dos gregos por mar para exigir uma indenização. Sem sucesso, resolve vingarse; para tanto, navega para terras gregas e se empenha a favorecer alguns adultérios: o de Clitemnestra, com Egisto; o de Egíale, esposa de Diomedes, com Cometes, filho de Estênelo $^{153}$; o de Meda, esposa de Idomeneu, com Leuco. Não satisfeito, faz uma fogueira sobre o monte Cafareu, na costa da Eubéia, para sinalizar aos barcos gregos vindos de Tróia a existência de um porto ali; enganados, são atraídos para escolhos e afundam ${ }^{154}$. Como vemos, Apolodoro apresenta duas vinganças de Náuplio. Severyns (1928b, p. 376), sondando escólios

\footnotetext{
${ }^{147}$ Poculum Homericum MB 36 (SINN) = test. D, fr. 10 W. No canto III (v. 299-312) da Odisséia, Nestor conta a Telêmaco a ida de Menelau ao Egito enquanto, em Micenas, ocorria a morte de Agamêmnon e a vingança de Orestes; e no XI (v. 405-434), o próprio fantasma de Agamêmnon explica os detalhes de sua morte a Odisseu.

${ }^{148}$ Segundo Ateneu (Deipnosophistae, 399a = fr. 8 D, fr. $12 \mathrm{~W}$ ), o poeta dos Retornos (dos Atridas) relatava no livro III como Hermioneu perseguiu Iso e o feriu na virilha com uma lança. West (2003a, p. 163, n. 66) estima que Hermioneu seja um filho de Menelau que auxiliou Orestes na luta contra os homens de Egisto.

${ }^{149} \mathrm{Na}$ Odisséia (IV, v. 351-568), Menelau conta a Telêmaco episódios pertinentes aos Retornos: sua ida ao Egito, onde encontrou Proteu, o qual lhe revelou as mortes do Ájax lócrio e de Agamêmnon e a vingança de Orestes.

${ }^{150}$ Pausânias (I, 22, 6), comentando pinturas na Acrópole de Atenas (sem as ligar a um poema específico), informa que os outros dois filhos de Náuplio auxiliaram Egisto contra Orestes e Pílades, mas acabaram mortos.

${ }^{151}$ Fr. $1 \mathrm{D}$, fr. $11 \mathrm{~W}$.

${ }^{152}$ Referida nos Cantos Cíprios. Palamedes foi lapidado pelos gregos a mando de Agamêmnon, sob uma acusação de traição engendrada por Odisseu.

${ }^{153}$ Apesar do retorno em segurança, o destino de Diomedes não lhe reserva uma boa surpresa em Argos: sua esposa comete adultério com o homem a quem entregou a guarda de seu reino e de sua morada. Tal adultério seria resultado de uma vingança de Afrodite, ferida pelo herói na guerra. Examinando escólios a uma passagem da Ilíada que sugere uma vingança da deusa (V, v. 410-415), Severyns (1928b, p. 371-376) levanta a hipótese de que o poema Retornos abordaria tal adultério.

${ }^{154}$ Sófocles teria composto uma, ou mesmo duas tragédias sobre a vingança de Náuplio (RADT, fr. 425-438). O tema aparece ainda em Eurípides (Helena, v. 766-767; v. 1126-1131), Licofron (Alexandra, v. 384), Propércio (IV, 1, 115-116), Sérvio (ad Aen., XI, v. 260).
} 


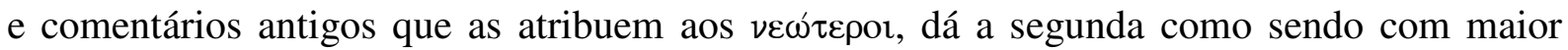
probabilidade a dos Retornos.

Outro episódio não mencionado no sumário de Proclus e ao qual se reporta a maior parte dos fragmentos dos Retornos diz respeito a uma nekyia. Em seu comentário às pinturas de Polignoto na Lesque em Delfos, Pausânias refere-se à nekyia desse poema diante de três personagens: ao ver o demônio Eurínomo, alega que os Retornos, apesar de descreverem o Hades e o terror nele existente, não faziam menção a essa entidade infernal $(X, 28,7)^{155}$; ao ver Clímene, conta que nos Retornos era filha de Mínias, casada com Céfalo, filho de Díon, e mãe de Íficlo $(\mathrm{X}, 29,6)^{156}$; ao ver Mera, informa que nos Retornos morre como serva e que era filha de Preto, filho de Tersandro, o qual, por sua vez, era filho de Sísifo (X, 30, 5).

A respeito da alusão a Mera, Severyns (1928b, p. 390-393) comenta o episódio de Sísifo na Odisséia (XI, v. 593-600 - parte integrante de 63 versos (v. 565-627) considerados interpolações por Aristarco): esses versos viriam dos Retornos, e o relato exposto em um escólio (DINDORFIUS) ao verso 153 do canto VI da Ilíada, atribuído a Ferecide, corresponderia à história de Sísifo presente nos Retornos:

Tendo arrebatado Egina, filha de Asopo, Zeus a transportou de Filonte a Enone, passando por Corinto. Apurando tal rapto, Asopo foi habilmente informado por Sísifo. Isso valeu a este a ira de Zeus, que então lhe mandou a Morte. Ciente da vinda dessa entidade, Sísifo a acorrentou com firmeza, tão bem que ninguém mais morria. Essa situação persistiu até que Ares livrou a Morte de suas cadeias e lhe entregou quem a capturara. Contudo, antes de morrer, Sísifo recomendou à esposa, Mérope, que não lhe dedicasse os presentes de costume. Ora, depois de certo tempo, como a mulher nada ofertava ao marido, Hades se deu conta do caso e enviou Sísifo para reprimi-la. De volta a Corinto, ele tomou todas as precauções para não retornar antes de morrer de velhice. Nos Infernos, foi condenado a rolar uma pedra, para não mais poder fugir. ${ }^{157}$

Na nekyia dos Retornos, ao lado da história de Sísifo, compondo um quadro de impiedade, Severyns supõe que haveria ainda a história de Salmoneu ${ }^{158}$ (p. 393-395), que se

\footnotetext{
${ }^{155}$ Fr. 3 D, fr. $1 \mathrm{~W}$.

${ }^{156}$ Fr. 4 D e W.

157 “Zeus ayant dérobé Égina, la fille d'Asopos, la transporta de Philonte à Oenone en passant par Corinthe. Asopos, qui s'informait sur le rapt, fut habilement renseigné par Sisyphe ; et cela valut à celui-ci la haine de Zeus, qui lui envoya donc la Mort. Sachant qu'elle venait, Sisyphe l'enchaîna, solidement, si bien qu'il arriva que plus personne ne mourut. Cela dura jusqu'à ce qu'Arès eût débarrassé la Mort de ses liens, et lui eût livré Sisyphe. Mais avant de mourir, Sisyphe recommanda à sa femme Méropé de ne pas envoyer dans l'Hadès les présents d'usage. Or, après un certain temps, comme la femme n'envoyait rien pour Sisyphe, Hadès s'en rendit compte et envoya Sisyphe pour gourmander sa femme. Rentré à Corinthe, Sisyphe n'eut garde de revenir avant d'être mort de vieillesse. Il fur condamné à rouler dans les Enfers un rocher, afin qu'il ne pût pas s'enfuir à nouveau." (Severyns, 1928b, p. 393).

${ }^{158}$ Escólio (DINDORFIUS) ao verso 236 da Odisséia e Apolodoro (I, 9, 7).
} 
pretendia igual a Zeus, e a de Forbas ${ }^{159}$ (p. 398-399), o orgulhoso pugilista morto por Apolo, façanha que valeu ao deus o título de patrono do pugilato.

Enfim, com a nekyia desse épico também deve se relacionar uma notícia de Ateneu (Deipnosophistae, 281b) ${ }^{160}$ : os Retornos (dos Atridas) abordavam a lenda de Tântalo, sua devoção aos prazeres sensuais e o castigo disso advindo.

Cabe agora questionar em que momento do épico aconteceria essa nekyia.

Davies (1989a, p. 80-81) levanta a hipótese de esse episódio estar ligado à suposta alusão a Tirésias na ocasião da morte de Calcante em Cólofon, onde deveria haver um cenotáfio erguido para Tirésias.

Para Severyns (1928b, p. 385-386), essa nekyia consistiria em um relato feito por Odisseu a Neoptólemo quando se encontram em Maronéia. Burgess (2001, p. 142-143) concorda com essa opinião e a torna mais ousada: o evento pode ter ocorrido em Maronéia e presidido por Odisseu. Isso teria duas implicações: os Retornos também abordariam Odisseu, e o estranho fato de Proclus não se referir a essa nekyia, tão bem atestada pelos fragmentos, resultaria de uma intenção de evitar a coincidência com a Odisséia.

Na trama do ciclo troiano, a temática dos Retornos é continuada pela Odisséia.

\section{Telegonia}

Em seguida, como sequiência e conclusão para a Odisséia ${ }^{161}$, vinha a Telegonia

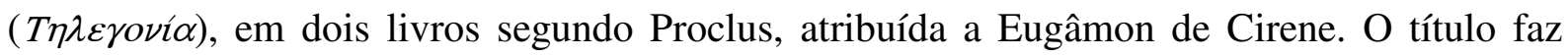
referência a um filho de Odisseu com Circe, Telégono (cuja etimologia indica "aquele que foi gerado longe"). O poema desenvolvia, até certo ponto, vaticínios feitos por Tirésias para Odisseu no canto XI da Odisséia (v. 119-137), incluindo a polêmica expressão do verso $134^{162}$ : "morte longe do mar" ou "morte vinda do mar". Para Davies (1989a, p. 26-27), essa seria a composição mais recente do ciclo troiano, situada por volta de 570 a. C. West (2003a, p. 19) propõe mais ou menos a mesma data, levando dois fatos em consideração: primeiramente, Eugâmon estaria em atividade na metade do século VI a. C.; além disso, a

\footnotetext{
${ }^{159}$ Escólio (DINDORFIUS) ao verso 660 do canto XXIII da Ilíada.

${ }^{160}$ Fr. 9 D, fr. 3 W.

${ }^{161}$ Sem a "Continuação", isto é, considerando seu fim no verso 296 do canto XXIII, como julgavam Aristófanes de Bizâncio e Aristarco.

${ }_{162}$ Nos escólios (DINDORFIUS) a esse verso, encontramos uma intensa discussão em torno de $\varepsilon \xi \alpha \lambda$ o (ou $\dot{\varepsilon} \xi$ $\left.\alpha \lambda o_{\zeta}\right)$ : em geral, com uma ou outra grafia, considera-se que no texto homérico isso equivale a "longe do mar", "no continente"; a outra interpretação, "vinda do mar", proviria da Telegonia (Severyns, 1928b, p. 412-415).
} 
atribuição do nome Arcesilau ao segundo filho de Ulisses com Penélope aludiria à dinastia governante de Cirene nessa época, que se dizia descendente de Odisseu - Arcesilau II, por exemplo, reinava por volta de 560 a.C.

O começo do poema seria uma continuidade ao massacre dos pretendentes de Penélope.

As famílias rendem honras fúnebres aos pretendentes mortos ${ }^{163}$.

Em agradecimento por uma dádiva recebida, Odisseu efetua sacrifícios para as Ninfas ${ }^{164}$ e parte em seguida rumo a Élis com a finalidade de inspecionar rebanhos. Nesse lugar, Polixeno, neto de Áugias, acolhe-o e oferece-lhe, em sinal de amizade, uma taça, na qual está representada a história de Trofônio, Agamedes e Áugias ${ }^{165}$. Cumprida a missão, retorna a Ítaca. Em casa, realiza os sacrifícios especificados por Tirésias ${ }^{166}$.

Depois, viaja para a terra dos tesprotas ${ }^{167}$; seguindo sempre instruções de Tirésias $^{168}$, cumpre sacrifícios para aplacar a ira de Posídon e se casa com Calídice, a rainha da região. Mais tarde, explode uma guerra entre os tesprotas, liderados por Odisseu, e os briges. Tomando o partido destes, Ares põe o exército de Odisseu em fuga; Atena, então, resolve enfrentá-lo em combate; mas Apolo intervém e estabelece a paz entre as duas divindades.

Tempos depois, Calídice falece. Nessa ocasião, o reino passa a Polipetes, filho dela com Odisseu, e este então retorna para Ítaca. Ao chegar, descobre que Penélope concebeu-lhe um novo filho, Poliportes ${ }^{169}$.

Enquanto isso, Telégono, ouvindo de Circe que ele é filho de Odisseu ${ }^{170}$, resolve navegar em busca do pai. Aporta em Ítaca e a devasta. Odisseu sai em defesa da ilha; Telégono, ignorando tratar-se de seu pai, enfrenta-o e fere-o com sua lança que possui na ponta uma espinha venenosa de um traquinídeo ${ }^{171}$. Odisseu morre em decorrência desse ferimento.

Logo depois, ciente do engano cometido, leva o corpo do pai, Telémaco e Penélope para a casa Circe. A divindade então os torna imortais e os envia à Ilha dos Bem Aventurados; ao fim, Telégono casa-se com Penélope, e Telêmaco com Circe $e^{172}$.

\footnotetext{
${ }^{163}$ Em acordo com a Odisséia (XXIV, v. 412-420).

${ }^{164}$ Prometidos na Odisséia (XIII, v. 356-360), por haver novamente posto os pés em Ítaca.

165 Trofônio e Agamedes, filhos de Ergino, habilidosos construtores de palácios e santuários, como o templo de Apolo em Delfos, foram contratados por Áugias, rei de Élis, avô de Polixeno, para construir uma casa do tesouro; além do combinado, teriam feito uma porta secreta no recinto, através da qual roubavam o rei; percebendo o roubo, Áugias preparou uma armadilha, na qual Agamedes foi apanhado; para evitar que o irmão fosse torturado ou para evitar seu envolvimento no caso, Trofônio o decapitou e desapareceu, fugido ou engolido pela terra que se teria aberto sob ele em um bosque sagrado da Lebadéia, no lugar conhecido como "Buraco de Agamedes" (PAUSÂNIAS, IX, 37, 5-7; CHARAX DE PÉRGAMO, apud JACOBY, F.Gr.Hist, 103, fr. 5).
} 
Com a Telegonia conclui-se o ciclo troiano.

Heródoto (Histórias, II, 121) relata uma aventura semelhante. Davies (1989a, p 89) destaca aqui dois tópicos da épica antiga: os presentes de hospitalidade e a ekphrasis em um artefato.

${ }^{166} \mathrm{Na}$ referida passagem da Odisséia (XI, v. 119-137).

167 Segundo Apolodoro (Epítome, 7, 34), Odisseu teria atravessado o Epiro a pé para chegar à terra dos tresprotas.

168 Odisséia, XI, v. 121-131.

169 PAUSÂNIAS (VIII, 12, 5) = fr. 1 D, fr. 3 W. Nessa passagem, Pausânias cita o poema com o nome de Thesprotis, que West (2003a, p. 19, n. 20) julga tratar-se do mesmo Telegonia. Mais cauteloso, Davies (1989, p. 88) emite três hipóteses: Thesprotis seria o mesmo Telegonia com um título alternativo, uma parte da Telegonia com um novo título ou um épico anterior que teria servido de modelo para a Telegonia. A segunda hipótese de Davies aproxima-se de uma de West (p. 19): a história dos tesprotas, não ligada a Cirene, pode constituir uma história à parte e mais velha que o resto do poema. A respeito da provável incorporação de um poema anterior à Telegonia, um testemunho (Test. W) de Clemente de Alexandria é significativo: Eugâmon teria roubado de um poema de Museu um livro inteiro com a história dos tesprotas. Quanto à multiplicação dos filhos de Odisseu, Hesíodo (Teogonia, v. 1011-1118) atribui-lhe quatro: Ágrio e Latino, com Circe; Nausítoo e Nausínoo, com Calipso. Os filhos se multiplicam e se diferenciam notadamente por interesses regionais de vincular uma determinada família à descendência do herói.

${ }^{170}$ EUSTÁCIO, Comentário da Odisséia, 1796, 49-51 (com Calipso, por engano, no lugar de Circe) = fr. 2 D, fr. 4 W. De acordo com esee fragmento, os filhos de Odisseu com Penélope são Telêmaco e Arcesilau; West (2003a, p. 171, n 72) supõe que Arcesilau seja um nome alternativo para Poliportes.

${ }^{171}$ Nesse passo, emerge o tema do filho que mata inconscientemente o pai, como Édipo. Quanto ao traquinídeo, trata-se de uma espécie de peixe característica do Mediterrâneo: trachinus draco, trachinus radiatus, trachinus araneus e Ecüchtys vipera. Segundo o schol. in Od., XI, v. 134, durante uma visita a Circe, Hefesto teria confeccionado essa lança para Telégono = fr. 5 W. Cf. OPIANO (séc. II d. C.), Haliêutica, II, v. 497-505.

${ }^{172}$ EUSTÁCIO, Comentário da Odisséia, 1796, $52-54$ (com Retornos, por engano, no lugar da Telegonia) $=$ fr. 2 D, fr. $6 \mathrm{~W}$. 


\section{Conclusão do capítulo}

A Ilíada e a Odisséia espalharam sementes em solos gregos; tempos depois, germinavam aqui e ali as demais epopéias do ciclo troiano. Estas últimas cresceram e deram frutos, colhidos por Píndaro, Ésquilo, Sófocles, Eurípides, Licofron, Catulo, Virgílio, Quinto de Esmirna... e tantos outros poetas. Porém logo feneceram.

Indaga-se agora um pouco mais a sina desses poemas perdidos: surgimento, reunião em um ciclo, declínio, até quando e em que circunstâncias sobreviveram...

Ao longo deste capítulo, desfilaram diversas teses relativas à datação dos poemas, as quais situam as composições entre o último quartel do século VIII e meados do século VI a. C. Tomando parte nessa discussão, Burgess (2001, p. 8-12) critica os critérios usados para essas datações, principalmente as abordagens fundamentadas em representações figuradas de supostos episódios dos poemas e as fundamentadas em análises lingüísticas dos fragmentos. Partindo do princípio de que as epopéias foram elaboradas em um contexto oral antes de serem fixadas na escrita, esse estudioso pondera o seguinte: haveria muitos poemas diferentes abordando episódios iguais; por detrás dessas composições, residia ainda a mitologia, uma fonte comum a poetas e pintores; quanto às formas lingüísticas, podem refletir apenas uma versão posterior (resultante de atualizações feitas por rapsodos ${ }^{173}$ ) de um épico composto antes oralmente. Diante dessas dificuldades, prefere uma posição cautelosa quanto à datação e à fixação escrita dos poemas do ciclo troiano (p. 12): essas obras teriam sido "cristalizadas" em performances da tradição oral no período arcaico e fixadas na escrita somente no final desse período. Essa cautela, no entanto, faz uma concessão à Telegonia, motivada por um fator externo: se Eugâmon de Cirene foi de fato o autor desse épico, sua criação deveria se situar no século VI a. C., pois a cidade de Cirene foi fundada no final do século VII a. C..

Compostos e fixados na escrita, quando esses épicos foram reunidos em ciclos? Para West (2003a, p. 3), em algum momento do século IV a.C., provavelmente em meios peripatéticos, alguns dos poemas cíclicos (no mínimo os do ciclo troiano) foram agrupados de tal forma que pudessem ser lidos em seqüência; desde então, seriam registrados em conjunto, como aparecem na Chrestomathia de Proclus.

${ }^{173}$ Cf. PAVESE, 1998. 
De fato, os peripatéticos dedicaram-se à composição de obras com a finalidade de repertoriar, organizar e até mesmo analisar as produções literárias gregas, uma combinação de história e crítica literária. O próprio Aristóteles, além de sua Poética, publicou uma lista de

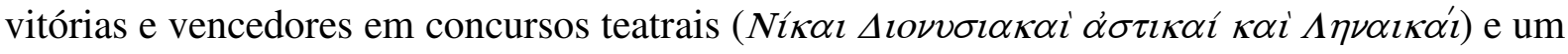
catálogo de informações a respeito dos dramas (datas, autores, sucesso obtido...), intitulado $\Delta \imath \delta \alpha \sigma \kappa \alpha \lambda i \alpha z$. Dentre os trabalhos peripatéticos nesse domínio, citemos dois que deveriam estudar diversas epopéias em função das tragédias. Dicearco (floruit 320 a.C.), o discípulo de

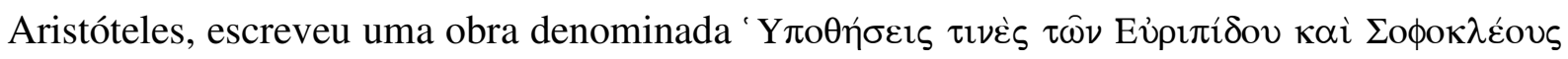

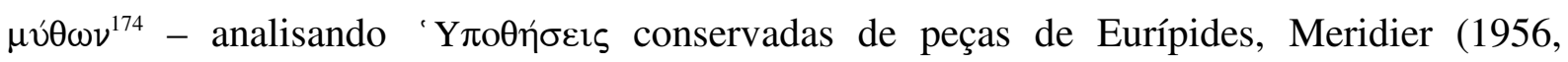
"Introduction", p. xvii) atesta que elas contêm bem mais do que os simples argumentos das peças: o assunto e sua proveniência, ou quem o tinha abordado antes, o lugar onde o drama se desenvolve, a composição do coro, a qualidade do $\pi \rho 0 \lambda \mathrm{o} \gamma \boldsymbol{i} \zeta \omega \nu$, as partes principais da peça, um resumo da didascália relativa à primeira representação e, para concluir, um julgamento estético. E Asclepíades de Tragilo (século IV a.C.) compôs uma obra em seis livros

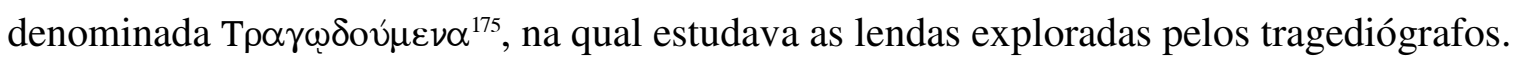

Em meio ao interesse dos peripatéticos por tais investigações, Aristóteles teria sido naturalmente levado a examinar epopéias ao efetuar estudos sobre a tragédia. Indo ao encontro de tal perspectiva, a mais antiga referência à noção de poesia épica grega compondo

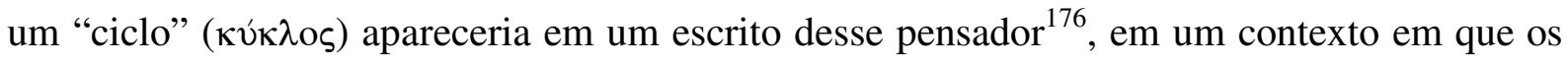
poemas dos ciclos épicos seriam atribuídos a Homero $^{177}$ por determinados sofistas (“Erísticos"), contra os quais Aristóteles escreve.

Todavia, não há consenso quanto à idéia de que Aristóteles realmente conhecesse e se referisse aos ciclos épicos nessa passagem. Para Burgess (2001, p. 15), por exemplo, talvez o

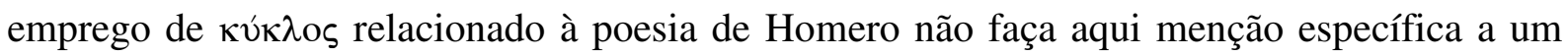
ciclo épico, mas apenas reflita (e de forma metafórica) uma "equação costumeira" estabelecida entre esse poeta e o gênero épico. Ele argumenta ainda que Aristóteles, ao comentar epopéias, não costuma empregar a noção de ciclo. Com efeito, na Poética,

\footnotetext{
${ }^{174}$ SEXT. EMP., Adv. Math., III, 3.

175 Obra muito citada nos escólios de Eurípides - cf. MERIDIER (Euripide, 1956, "Introduction", p. xv) e GUIDORIZZI (1995, in: APOLLODORO. Biblioteca, p. XXXI-XXXII).

${ }^{176}$ Commentaria in Aristotelem Graeca, 13, 3: Philoponi in Analyt. Post. I. 12 [77 32$]=$ test. *2 D.

177 Segundo Burgess (2001, p. 8), até o século V a. C., vários poemas do Ciclo eram atribuídos a Homero, figura mitológica vista como a fonte da narrativa épica tradicional. A partir disso, ele supõe que seus autores não seriam conhecidos.
} 
$(1459 \text { a37 })^{178}$, Aristóteles critica os Cantos Cíprios e a Pequena Ilíada quanto ao princípio da unidade sem mencionar a participação desses épicos em um ciclo.

Discutindo a "manipulação editorial" desses poemas, Burgess (p. 12-16) considera que isso aconteceu no período alexandrino e que não surgiu de repente e do nada, mas de um longo processo: em primeiro lugar, em termos mitológicos, temáticas como a da guerra de Tróia deveriam ser vistas como um "ciclo" de histórias formadoras de uma unidade; em termos poéticos, o gênero épico poderia também ser percebido como cíclico. Em segundo lugar, os rapsodos, ao reunirem em suas apresentações partes de diferentes épicos, talvez até mesmo forjando um encadeamento cronológico, teriam prefigurado a idéia dos ciclos épicos, concebendo verdadeiros protótipos. Em terceiro lugar, a imposição de regras para a performance dos rapsodos em festivais, como nas Panatenaicas, poderia também ter orientado o trabalho editorial criador dos ciclos.

No período alexandrino, a existência de poemas integrantes de ciclos encontrava-se bem atestada, o que sugere uma elaboração anterior. A epigrama 28 de Calímaco é sempre

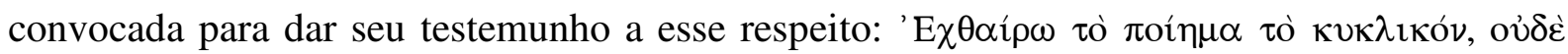

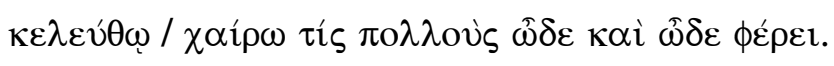

A presença desses poemas no universo alexandrino tornou-se mais evidente nos estudos empreendidos por eruditos. Em sua grande investigação, Severyns (1928b) demonstra que Aristarco da Samotrácia (220-144 a. C.), um dos bibliotecários de Alexandria, conhecia os poemas do ciclo troiano e que deles se servia para justificar suas lições. Na exegese da Ilíada e da Odisséia, adotou como princípio metodológico tentar explicar esses poemas permanecendo fiel, enquanto possível, a Homero, isto é, sem tomar lenda, expressão ou palavra que lhe parecesse pós-homérica. Nesse processo, cunhou classificações para distinguir

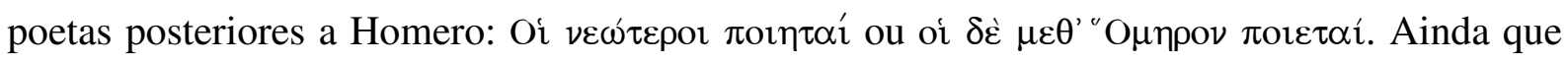
essa terminologia aparecesse com mais consciência crítica, com valor realmente técnico nos trabalhos de Aristarco, não se pode afirmar que a tenha inventado: seu mestre, Aristófanes de

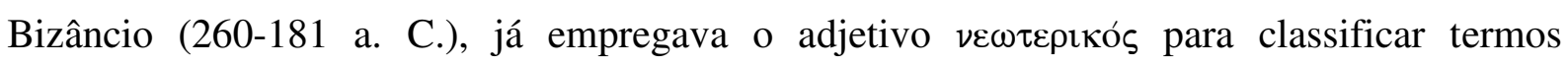
posteriores a Homero, como se constata no escólio (DINDORFIUS) ao verso 206 do canto II

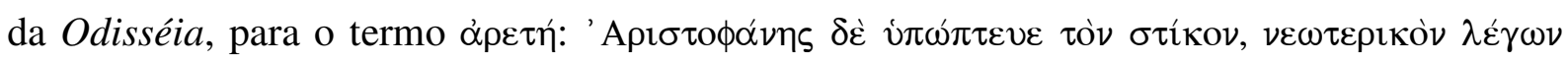

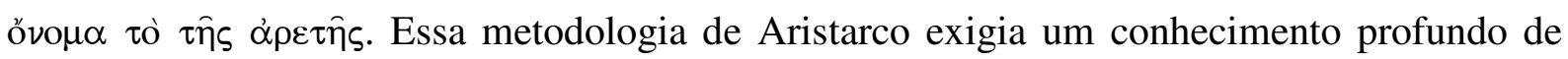

\footnotetext{
${ }^{178}$ Passagem comentada no estudo da Pequena Ilíada.
} 
toda a literatura grega desde Homero até sua época, do contrário correria o risco de fazer análises equivocadas. Entre os $v \varepsilon \omega \tau \varepsilon \rho o$, encontravam-se os poetas cíclicos; e, de acordo com

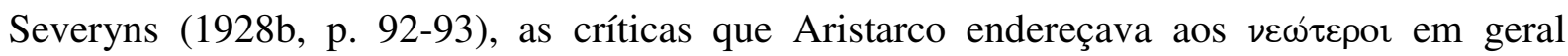
valiam em especial para os cíclicos, poetas julgados inábeis e acusados de desfigurar os poemas homéricos:

Aristarco deve ter percebido que os poetas cíclicos deviam muito a Homero, que a existência da Ilíada e da Odisséia tornava possível a de poemas que narravam o que aconteceu antes e depois dos eventos narrados por Homero. E, ao perceber isso, percebeu também que essa nova floração épica testemunhava uma

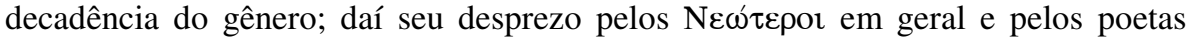
cíclicos em particular, continuadores e imitadores inábeis do poeta por excelência. ${ }^{179}$

A partir do poema de Calímaco e dos comentários de Aristarco, delineia-se um julgamento alexandrino desfavorável aos ciclos épicos, e a noção de "poema cíclico" parece ter incorporado um valor pejorativo. Para Severyns (1928b, p. 74), as críticas de Aristarco contribuíram para que esses poemas deixassem de ser lidos e, em conseqüência, recopiados.

Severyns (1928b, p. 28) e Burgess (2001, p. 16-17) concordam quanto ao fato de os poemas dos ciclos épicos terem perdido seu crédito poético, mas acrescentam que seu conteúdo e a idéia de ciclo não perderam valor, pois, enquanto os poemas cíclicos entravam em decadência, tanto seu conteúdo quanto o princípio de ordenação desse conteúdo eram resgatados por sumários e emergiam em trabalhos de mitógrafos, como Apolodoro e Higino $^{180}$. Aliás, conforme o comentário de Photius ${ }^{181}$ exposto a seguir, esse princípio organizacional teria concedido ao conjunto de poemas uma qualidade capaz de resistir mais tempo ao esquecimento:

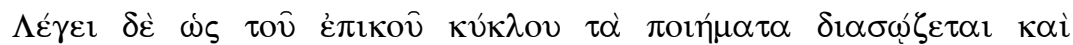

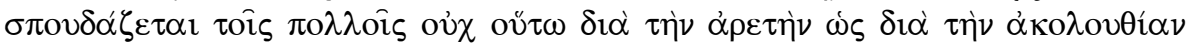
$\tau \hat{\omega} \nu$ ह่v $\alpha \dot{\tau} \tau \hat{\omega} \pi \rho \alpha \gamma \mu \alpha \dot{\tau} \tau \omega \nu$.

E ele diz que os poemas do ciclo épico estavam conservados e que atraíam o interesse de muitos não por sua virtude, mas por conta da seqüência de acontecimentos neles apresentada.

\footnotetext{
179 “Aristarque dut remarquer que les Cycliques doivent beaucoup à Homère, que l'existence de l'Iliade et de l'Odyssée rendait possible celle de poèmes racontant ce qui s'était passé avant et après les événements que racontait Homère. Et, remarquant cela, il remarqua aussi que cette nouvelle floraison épique attestait une

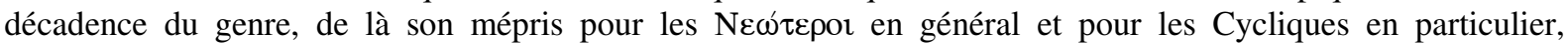
continuateurs et imitateurs maladroits du poète par excellence.".

${ }^{180}$ Cf. CAMERON (2004) e ainda BREMMER; HORSFALL (1987).

${ }^{181}$ PHOTIUS, Biblioteca, Codex 239, 20 Procli Chrestomathia, in: SEVERYNS, 1938, p. 36-37.
} 
Os poemas cíclicos teriam realmente chegado à época de Proclus? Tal pergunta amplia o interesse pela identidade desse autor. Foi dito no princípio deste capítulo que duas hipóteses existem a esse respeito: poderia se tratar do filósofo neoplatônico morto em 485 ou de um gramático da época Antonina. Para aprofundarmos a questão, convoquemos um testemunho de Ioannus Philoponus (c.490-570) ${ }^{182}$; esse filósofo assegura que, pouco antes de sua época, era possível encontrar poemas cíclicos e que um poeta de nome Pisandro de Lauranda (séc. III) havia feito uma compilação em versos adaptada ao gosto literário de seu tempo. Apoiando-se no comentário de Photius e nessa afirmação de Philoponus, Severyns (1928b, p. 75-76) defende a seguinte hipótese: Proclus seria um gramático do século II, o qual teve acesso aos poemas cíclicos; na época de Pisandro de Lauranda, esses poemas (ou ao menos alguns) ainda existiriam, mas não despertariam mais interesse, daí o porquê de esse autor lhes haver dado uma nova roupagem; na época de Philoponus, esses poemas não mais existiriam. Em decorrência dessa reflexão, os poemas teriam desaparecido entre os séculos III e VI.

A despeito de hipóteses como essa, West (2003a, p. 4 e 12), sem discutir a época de Proclus, imagina que este não tenha conhecido os poemas originais, que tenha se servido de material alexandrino já em prosa. Jouan (1966, p. 20), por sua vez, avalia mais verossímil a hipótese de que Proclus fosse o filósofo neoplatônico do século V e também presume que não dispunha dos épicos originais, mas de hypothéseis desses poemas provenientes provavelmente de trabalhos alexandrinos ou mesmo de trabalhos peripatéticos anteriores.

Observe-se, enfim, o pensamento de Burgess (2001, p. 16-18), que confia no testemunho de Photius: Proclus teria consultado uma versão original dos épicos cíclicos para elaborar seus sumários. Como explicar, então, divergências entre testemunhos desses poemas e os sumários de Proclus? Para Burgess, as epopéias dos ciclos devem ter sofrido diversas alterações desde sua fixação na escrita até desembocarem nos sumários de Proclus. Inicialmente, no processo de edição, as versões escritas, independentes, devem ter sido adaptadas, inclusive com possíveis cortes, a fim de forjar uma continuidade coerente entre os poemas - com isso, teríamos em circulação as versões originais e independentes e as versões adaptadas integrantes dos ciclos. Forjados assim os ciclos, eles experimentariam outras alterações em seu processo de transmissão: os poemas foram sumariados em prosa e tempos depois os sumários referentes ao ciclo troiano podem ter recebido novas alterações ao serem

\footnotetext{
${ }^{182}$ F. Gr, Hist. I2 *10, 16 T 2. Filósofo de Alexandria, autor de vários tratados de teologia e filosofia, dentre os
} quais se destacam comentários de obras de Aristóteles. 
incluídos em edições dos poemas homéricos, com o propósito de evitar conflitos de conteúdo. Tais alterações explicariam divergências entre testemunhos e fragmentos e os sumários de Proclus, a última etapa desse processo. Um bom exemplo dessa teoria viria à tona nos Cantos Cíprios, no episódio da viagem de Páris de Esparta a Tróia: segundo Heródoto (História, II, 116-117), nesse épico, a viagem levava três dias sobre um mar calmo, impulsionada por vento favorável; no entanto, no sumário de Proclus, essa viagem vivencia uma tempestade e uma digressão por Sídon, fatos que entram em ressonância com o conteúdo da Ilíada (VI, v. 289292).

Essa teoria suscita algumas considerações. A questão de saber se Proclus teve ou não acesso aos poemas originais precisaria ser reformulada. Nesse caso, não se falaria das versões originalmente fixadas na escrita e independentes, mas das versões preparadas para a edição do ciclo. Cabe aqui perguntar o que aconteceu com as versões independentes, até quando devem ter circulado. Aristarco com certeza estudou as versões desses épicos transmitidas pelo ciclo, mas teria também manuseado às versões independentes?

Enfim, Proclus viveu no século II ou V? Que versão do ciclo troiano utilizou para elaborar seus sumários? Questões e hipóteses... a discussão continua aberta.

E quanto a Virgílio, teria conhecido essas epopéias perdidas? Nascido setenta e poucos anos após a morte de Aristarco e no mínimo dois séculos antes de Proclus, Virgílio provavelmente teve acesso a poemas do ciclo troiano. Em qual versão? Não se sabe. Sabe-se, todavia, que o poeta os explora em sua obra. Averigua-se a seguir como isso ocorre no episódio das pinturas do templo de Juno e na arquitetura dos seis cantos iniciais da Eneida. 
capítulo segundo

\section{As pinturas do templo de Juno e as epopéias do ciclo troiano}

Conhecidos os poemas do ciclo troiano, pode-se agora investigar elos entre eles e a Eneida propiciados pelo episódio das pinturas do templo de Juno.

De imediato, o assunto traz à tona uma polêmica: Virgílio teria conhecido as epopéias cíclicas através de versões em verso ou apenas através de sumários em prosa?. Ao folhear a matéria, Kopff (1981, p. 920-921) informa que os estudiosos mais antigos consideravam que o poeta não teria lido os "originais"; entre os mais recentes, a tendência é supor que teria lido ao menos o "original" do Etíope (de onde proveio Pentesiléia como modelo para Camila). Kopff estima não haver dúvidas quanto à leitura do "original" do Etíope e ainda do Saque de Ílion (modelo para o canto II); e, indo além dessa opinião, apresenta argumentos a favor da hipótese de que Virgílio teria conhecido versões “originais” de mais épicos cíclicos:

- a sobrevivência de várias tabulae iliacae indicaria uma subsistência de poemas perdidos do ciclo troiano ao menos até o século I a.C., tanto quanto a Ilíada, a Odisséia e a 'I $\lambda$ íov $\pi \varepsilon ́ p \sigma ı \varsigma$ de Estesícoro de Hímera (c.632 e 553 a.C.);

- a inexistência de razão sólida para desqualificar os testemunhos de Pausânias (X, 31, 2; IV $, 2,1)$ a respeito de sua leitura desse ciclo (como se viu no capítulo anterior);

- o testemunho de Ioannus Philoponus $(c .490-570)^{183}$, segundo o qual esses poemas ainda circulavam pouco antes de sua época;

- a informação de que Pisandro de Lauranda ${ }^{184}$, contemporâneo de Alexandre Severo (no poder de 222 a 235), teria vertido os poemas do ciclo troiano para a prosa, compondo um ciclo mitológico ao gosto da época.

Com essa argumentação, Kopff transfere a responsabilidade de provar (onus probandi) que Virgílio não teria lido os "épicos originais" para quem disso duvida.

\footnotetext{
${ }^{183}$ Abordado na conclusão do capítulo I.

${ }^{184}$ Segundo Macróbio (Saturnalia, V, 2, 4-5), um poeta chamado Pisandro narrou também o saque de Tróia, que seria a fonte do canto II da Eneida; acredita-se, porém, que Macróbio tenha confundido Pisandro de Lauranda, poeta posterior a Virgílio, com Pisandro de Camiros, poeta do século V a.C., autor de uma Heracleia.
} 
Diante da tese de Burgess (2001) exposta na conclusão do capítulo I, seria impróprio empregar a expressão "poemas originais" para as epopéias cíclicas, uma vez que sofreram adaptações no processo de edição dos ciclos. Assim, compreendamos a terminologia "poemas originais" no sentido de versões ainda em verso (integrantes de edições dos ciclos), derivadas das originais e independentes.

Corroborando a argumentação de Kopff, testemunhos da presença desses poemas no universo romano existem desde o princípio da literatura latina e tornam-se mais salientes na época de Virgílio. Névio (c.270-201 a. C.) teria composto uma epopéia intitulada Cypria Ilias, de onde vêm dois fragmentos dos Cantos Cíprios (fr. 7 e 13 W). Ênio (239-169 a. C.), seguindo os passos de Ésquilo, Sófocles e Eurípides, praticamente reconstituiu todo o ciclo troiano em forma de tragédia - ainda que esse fato não assegure seu contato com os poemas desse ciclo, revela a circulação da temática em solo romano e, o que é mais relevante, reproduz o fenômeno ocorrido na Grécia: a influência dos ciclos épicos sobre a tragédia. $\mathrm{O}$ epicurista, poeta e "crítico literário" Filodemo de Gádara (110-40 a. C.) ${ }^{185}$ manuseou poemas do ciclo troiano, e de seus comentários originaram-se três fragmentos dos Cantos Cíprios (fr. 2, 11 e 17 W) e um dos Retornos (fr. 9 W). E Horácio (65-8 a. C.) demonstra conhecimento dessas epopéias em sua Arte Poética: os versos 136-137, citados no estudo da Pequena Ilíada, criticam a proposição de um scriptor cyclicus; o verso 146 faz menção a um vó Diomedes - ao qual Virgílio também se refere na Eneida (XI, v. 255-277); e o verso 147 evoca explicitamente os Cantos Cíprios. Desses testemunhos, o de Filodemo e o de Horácio merecem uma apreciação particular: são indícios da circulação de edições versificadas desses épicos na época de Virgílio. Como supõe Kopff, é muito provável que Virgílio tenha tido aceso a essas edições em verso, e não apenas a sumários em prosa.

Não apenas por essa polêmica, tal episódio tem despertado o interesse de pesquisadores. Alguns se debruçam sobre sua carga significativa em relação à intriga do poema, como Gransden (1984, p. 2-3):

O mural no templo de Juno, no primeiro livro "odissíaco", constitui um dos motivos mais importantes do poema. Tudo que Enéias nele vê como findado e já superado - carnificina, sacrilégio, destruição - vivenciará novamente: de início, em sua própria retrospectiva dos últimos dias de Tróia, cujo vigor trágico é assegurado por uma narrativa em primeira pessoa e pela interposição de um leitor-ouvinte que se encontra emocionalmente envolvido com o narrador e espera para desempenhar ele próprio um papel trágico na temporalidade do esquema narrativo primário do

${ }^{185}$ OBBINK, 1995. 
poema; e então novamente nos livros finais "iliádicos" do poema, o relato da campanha na Itália. ${ }^{186}$

Gransden valoriza o potencial proléptico estocado nas pinturas. Outros estudiosos dedicam-se em especial à composição do episódio, como Williams (1960) e, mais recentemente, Putnam (1998), que propõe uma análise detalhada dessas imagens enquanto ekphrasis (tomada como descrição de uma obra de arte) ${ }^{187}$.

A abordagem desse episódio proposta aqui investiga, por sua vez, o processo alusivo feito pelas pinturas às epopéias do ciclo troiano, o princípio de ordenação das imagens em função desse processo alusivo e a exploração da arte da memória.

Para desenvolver essa investigação, deve-se de início definir as imagens e em seguida analisar os versos que as introduzem.

Dez imagens distinguem-se no episódio, assim delimitadas:

\begin{tabular}{|c|c|l|}
\hline Imagens & Versos & \multicolumn{1}{|c|}{ Texto } \\
\hline I & 458 & $\begin{array}{l}\text { Atridas Priamumque et saeuom ambobus Achillem. } \\
\text { En Priamus. }\end{array}$ \\
\hline II & 461 & $\begin{array}{l}\text { Namque uidebat uti bellantes Pergama circum } \\
\text { hac fugerent Grai, premeret Troiana iuuentus, }\end{array}$ \\
III & 468 & hac Phryges, instaret curru cristatus Achilles. \\
\hline IV & $469-473$ & $\begin{array}{l}\text { Nec procul hinc Rhesi niueis tentoria uelis } \\
\text { adgnoscit lacrimans, primo quae prodita somno } \\
\text { Tydides multa uastabat caede cruentus, } \\
\text { ardentisque auertit equos in castra prius quam } \\
\text { pabula gustassent Troiae Xanthumque bibissent. }\end{array}$ \\
\hline V & $474-478$ & $\begin{array}{l}\text { Parte alia fugiens amissis Troilus armis, } \\
\text { infelix puer atque impar congressus Achilli, } \\
\text { fertur equis curruque haeret resupinus inani, } \\
\text { lora tenens tamen; huic ceruixque comaeque trahuntur } \\
\text { per terram, et uersa puluis inscribitur hasta. }\end{array}$ \\
\hline
\end{tabular}

\footnotetext{
186 "The murals in Juno's temple in the first "Odyssean" book constitute one of the poem's most important motifs. Everything Aeneas sees there as over and done with - slaughter, sacrilege, destruction - he will live through again: first in his own retrospective narrative of the last days of Troy, the tragic power of which is secured by the shift into a first-person narrative and the interposition of a reader-hearer who is herself emotionally involved with the narrator and waiting to play a tragic role herself inside the temporality of the poem's primary narrative scheme; and then again in the poem's iliadic closing books, the narrative of the Italian campaign.”.

187 Além dos indicados no texto, vale ressaltar os trabalhos de Heyne (1832), Henry (1873), Cartault (1926), Williams (1972), Austin (1971) e Clay (1988).
} 


\begin{tabular}{|c|c|l|}
\hline & & \\
\hline VI & $479-482$ & $\begin{array}{l}\text { Interea ad templum non aequae Palladis ibant } \\
\text { crinibus Iliades passis peplumque ferebant } \\
\text { suppliciter, tristes et tunsae pectora palmis; } \\
\text { diua solo fixos oculos auersa tenebat. }\end{array}$ \\
\hline VII & $483-487$ & $\begin{array}{l}\text { Ter circum Iliacos raptauerat Hectora muros } \\
\text { exanimumque auro corpus uendebat Achilles. } \\
\text { Tum uero ingentem gemitum dat pectore ab imo, } \\
\text { ut spolia, ut currus, utque ipsum corpus amici } \\
\text { tendentemque manus Priamum conspexit inermis. }\end{array}$ \\
\hline VIII & 488 & $\begin{array}{l}\text { Se quoque principibus permixtum adgnouit Achiuis } \\
\text { Eoasque acies et nigri Memnonis arma. }\end{array}$ \\
\hline X & $490-493$ & $\begin{array}{l}\text { Ducit Amazonidum lunatis agmina peltis } \\
\text { Penthesilea furens medisque in milibus ardet, } \\
\text { aurea subnectens exsertae cingula mammae } \\
\text { bellatrix, audetque uiris concurrere uirgo. }\end{array}$ \\
\hline
\end{tabular}

Não há consenso quanto à identificação das imagens; a exposta acima é justificada na parte I deste capítulo, no curso da análise de cada imagem ${ }^{188}$.

Quanto à disposição das pinturas no templo, o texto denota duas séries: a primeira com as quatro imagens iniciais (o emprego de marcadores espaciais reforça a idéia de conjunto: hac... hac, Nec procul hinc); a segunda com as seis restantes, e a separação do primeiro grupo é bem estabelecida por Parte alia. Explicando o verso 474, Sérvio já admite a localização da segunda série em outra parte do templo ('parte alia' scilicet templi). Paratore (ad I, v. 475) julga o mesmo e ainda se serve da expressão Parte alia para justificar uma suposta ruptura na ordem cronológica das imagens, manifestada em especial no episódio de Troilo:

Todavia, o inconveniente pode facilmente ser sanado ao observarmos que Em uma outra parte parece indicar o início de uma nova série de afrescos sobre uma outra parede do templo. 189

Não é possível saber ao certo se as duas séries se configuram em paredes diferentes ou em uma mesma, com a distinção marcada apenas por um afastamento maior. É possível, entretanto, como pensa Williams (1960, p. 151), imaginar Enéias caminhando no tempo, contemplando as pinturas... como se estivesse em uma galeria de arte.

\footnotetext{
${ }^{188}$ Nessa ocasião, a tradução dos versos é fornecida.

189 "Ma l'inconveniente può facilmente sanarsi osservando che In un'altra parte sembra indicare l'inizio di una nuova serie di affreschi sopra un'altra parete del tempio.".
} 
A contemplação das imagens nessa "galeria" é introduzida pelos seguintes versos (I, v. 450-458):

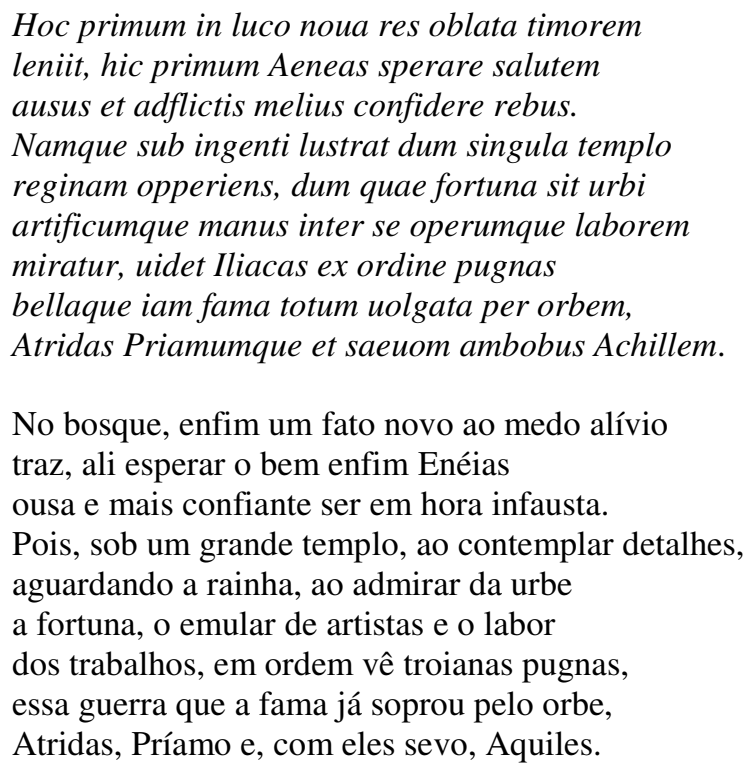

Nessa passagem, distinguem-se claramente duas seções. A primeira, do verso 450 ao 452, anuncia a iminência de algo inesperado e alvissareiro: após tanto sofrimento, Enéias vai descobrir nesse bosque o primeiro alívio para seu temor, a primeira esperança de salvação, o que lhe concederá mais confiança para enfrentar as adversidades. E a repetição do termo primum caracteriza essa descoberta como um verdadeiro divisor de águas na sina de Enéias. Mantendo o suspense, esses versos criam expectativa no receptor e desse modo intensificam a importância do evento iminente... a importância do episódio das pinturas.

A segunda, do verso 453 ao 458, revela enfim a noua res: pinturas nas paredes de um templo representando episódios da guerra de Tróia.

Ao discutir esse episódio, Alessandro Barchiesi (1999 ${ }^{190}$, p. 333-335) explora um significativo aspecto da épica antiga: a fama do herói. Segundo ele, haveria na Eneida (em particular no canto inicial) a evidente intenção de edificar uma nova fama para Enéias, cujos alicerces encontrar-se-iam nos poemas do ciclo troiano, razão pela qual as pinturas constituiriam uma seleção de episódios desses épicos ${ }^{191}$. Fundamentando-se nessa idéia, examina de forma mais detida esses versos introdutórios. Do ponto de vista metapoético,

\footnotetext{
${ }^{190}$ Artigo publicado pela primeira vez em 1994.

${ }^{191}$ Putnam (1998, p. 24) também salienta o fato de Enéias perceber a celebração da guerra de Tróia através da pintura de seus episódios e o revestimento de imortalidade, ou seja, a fama que o acontecimento e seus protagonistas assim adquirem.
} 
enquanto Enéias, aguardando a rainha, admira o trabalho dos artífices e o labor de suas obras, o receptor estaria diante de uma alusão ao trabalho (labor) de diversos poetas que criaram, emulando entre si (inter se), obras pertencentes ao ciclo troiano. No que concerne à expressão

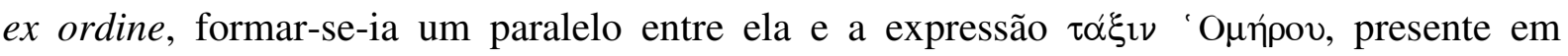
algumas das Tabulae Iliacae ${ }^{192}$ (consideradas por ele uma versão das pinturas do templo de Juno), e mais particularmente entre $\tau \alpha \xi_{1 v}$ e ordo, termos cujo valor retórico é reconhecido: índices de uma determinada organização do conteúdo de um texto. Nessa circunstância, a Tabula Capitolina teria uma conexão ainda maior com os ciclos épicos, dada a disposição "circular" de seu conteúdo. Depois dessas considerações, A. Barchiesi (p. 334) infere o seguinte a respeito da ordem das pinturas e do posicionamento da Eneida em relação à poesia cíclica:

Enéias vê no templo Iliacas ex ordine pugnas (1.456), e ordo, como vimos, é um
termo técnico. O Ciclo conta a seqüência do mito de forma contínua - e Virgílio,
através do olhar de Enéias, escolhe um arranjo que não é de modo algum
cronológico: os eventos que nos são apresentados não estão ex ordine, a própria
Eneida não narra sua história ex ordine e, em vários aspectos, recusa-se a ser um
novo poema no Ciclo, uma crônica. 193

Nessa análise, ex ordine adquire uma conotação complicada. De fato, tal expressão se configura como um dos problemas dos estudos virgilianos: revestida de um relevo retórico, anuncia a existência de uma determinada ordem na disposição das imagens, a qual, no entanto, permanece desconhecida. Diante dessa dificuldade, A. Barchiesi prefere interpretar a suposta falta de ordenação como uma recusa de Virgílio à poesia cíclica: a Eneida não seria um novo poema cíclico.

Prosseguindo, A. Barchiesi (p. 334) sugere para o termo uolgata um conteúdo programático (pós-calimaquiano) ${ }^{194}$ : em fama uolgata, residiria a noção de uma fama "vulgarizada" pela poesia cíclica. Em seguida, convocando os versos 131 e 132 da Arte Poética de Horácio para apoiar sua argumentação, vê em orbis uma alusão à falta de originalidade das composições cíclicas.

\footnotetext{
${ }^{192}$ Cf. SADURSKA, 1964.

193 “Aeneas sees in the temple Iliacas ex ordine pugnas (1.456), and ordo, as we have seen, is a technical term. The Cycle recounts the sequence of the myth continuously - and Virgil, through the eyes of Aeneas, chooses an arrangement which is absolutely not chronological: the events which are presented to us are not ex ordine, the Aeneid itself does not narrate his story ex ordine, and in many respects it refuses to be a new poem in the Cycle, a chronicle.".

${ }^{194}$ Segundo ele, já empregado com esse sentido nas Geórgicas (III, v. 4).
} 
Embora A. Barchiesi conteste a implicação natural de ex ordine, sua análise reforça a idéia de que as pinturas estejam dispostas segundo um determinado princípio e salienta a referência feita ao ciclo troiano.

O plano metapoético desse trecho alarga-se ao ligarmos a expressão fama uolgata às indagações que Enéias endereça a Acates diante do mural (v. 459-460): "Quis iam locus" inquit “Achate, / quae regio in terris nostri non plena laboris?”. Pinturas de episódios da guerra de Tróia (concebidas a partir de epopéias) divulgam pelas regiões da Terra as façanhas de heróis; em verdade, o poeta expõe um processo comum à poesia épica, caracterizado pela transmissão de seu conteúdo através da linguagem figurativa: inicialmente, ao registrar os feitos dos heróis, um poema corporifica a fama; depois, episódios de tais poemas inspiram representações figurativas ${ }^{195}$.

A Eneida desse modo convida seu receptor a uma discussão a respeito não apenas da fama (da guerra de Tróia, de Enéias) e da elaboração dessa fama (artificumque manus inter se) mas também de sua transmissão (uolgata per orbem).

Configurando-se como índices da estrutura comunicativa do poema, as expressões artificumque manus inter se, ex ordine e fama totum uolgata per orbem delineiam um rico plano de sentido metapoético, no qual Virgílio e Enéias interagem, completam-se.

Cabe ao receptor aceitar esse convite, perscrutar índices que o episódio das pinturas do templo de Juno lhe endereça e assim concretizar sentidos.

\footnotetext{
195 Austin (ad I, v. 456) refere várias pinturas que Virgílio provavelmente contemplou, possíveis fontes desse episódio. Esse estudioso supõe que o poeta realmente tenha conhecido murais similares ao do templo de Juno.
} 


\section{II.1 - Alusão das imagens a épicos do ciclo troiano}

A investigação aqui realizada fundamenta-se no pressuposto de que existe uma relação estabelecida de modo consciente entre as pinturas e poemas do ciclo troiano. Seguindo esse princípio, examina-se a qual epopéia cada imagem faz alusão. Isso não significa dizer que as imagens evoquem apenas poemas desse ciclo - aliás, alusões a outras obras serão mencionadas e eventualmente discutidas.

\section{II.1.1 - Imagem I (v. 458 e 461) \\ Atridas Priamumque et saeuom ambobus Achillem. \\ ... \\ En Priamus. \\ Atridas, Príamo e, com eles sevo, Aquiles. \\ Eis Príamo.}

O verso 458 não somente conclui o texto introdutório mas também veicula a primeira imagem. Esse verso tem sido interpretado como parte da introdução das pinturas, sem referência a uma imagem específica. Tal interpretação, no entanto, revela-se ilógica e pode ser contestada pela ausência dos atridas nas demais pinturas - seria difícil conceber o anúncio de algo que depois não é abordado. Com efeito, como se há de ver, esse verso constitui a primeira imagem e nela os atridas de fato figuram.

Como reconhece A. Barchiesi (1999, p. 342, n. 13), esse verso alude ao último do proêmio da Ilíada (v. 7):

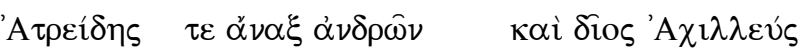

$$
\begin{aligned}
& \text { Atridas Priamumque et saeuom ambobus Achillem }
\end{aligned}
$$

A correspondência forjada entre os elementos dos versos leva o receptor a estabelecer

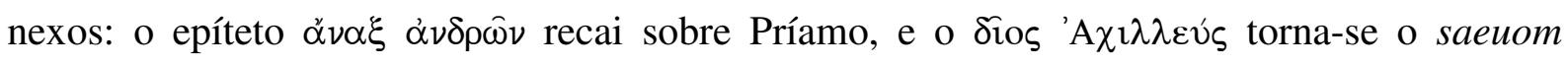
Achillem. Tais relações sugerem o ponto de vista a partir do qual as imagens são apresentadas ao receptor da Eneida e "lidas" por Enéias: para os troianos, o chefe de homens é Príamo, e Aquiles é um ser furioso, cruel. E o termo saeuom revela-se um índice desse ponto de vista: esse adjetivo não reproduz qualquer traço da imagem, pois as pinturas encontram-se em um templo dedicado a Juno, protetora dos gregos, logo celebram façanhas gregas e de sua divindade protetora. 
Por conseguinte, o verso 458, abrindo o mural, evoca o proêmio e ainda o assunto do canto I da Ilíada (a querela entre Aquiles e Agamêmnon e o retiro do pelida), todavia com um ponto de vista diferente ${ }^{196}$.

Enéias pára diante dessa primeira imagem, que nele desperta todo o sofrimento infligido pela queda de Tróia (Constitit et lacrimans, v. 459), e manifesta o que sente (v. 459463).

De início, exprime surpresa ao descobrir que a guerra contra os gregos é conhecida em terras tão distantes de Tróia (v. 459-460). Ressalte-se nesse trecho o termo labor, que faz menção aos feitos bélicos troianos e evoca o labor artístico do verso 455 (operumque laborem), adquirindo um duplo sentido: enquanto Enéias reporta-se a feitos bélicos, Virgílio infunde nesse termo uma alusão a feitos poéticos; em outras palavras, é graças ao labor de um Virgílio (via pintura neste caso) que todas as regiões da Terra conhecem o labor de um Enéias ${ }^{197}$. Desse modo, labor toma parte na discussão metapoética acerca da transmissão da fama.

Pouco depois, Enéias focaliza na imagem a figura do monarca troiano, mostrando-a a Acates: En Priamus. Uma vez que o verso 458 não é considerado indicativo de uma pintura específica, costuma-se ver nessa expressão uma referência à cena do cadáver de Heitor (v. 483-487): haveria apenas essa imagem com Príamo, para a qual Enéias estaria olhando no verso 458, no 461 e nos 483-487 (nos quais seria enfim detalhada) ${ }^{198}$. Todavia, parece no mínimo improvável que Enéias, ao perceber a imagem com o cadáver de Heitor, deixasse de lado a morte desse herói e nela destacasse de imediato apenas Príamo, em seguida a esquecesse, passando a observar outras representações, e somente mais tarde voltasse à imagem inicialmente destacada e a contemplasse em detalhes. Mais coerente é pensar que a expressão En Priamus designe o verso 458, sobretudo porque se sabe que as pinturas são filtradas por um ponto de vista troiano: em face de uma representação com os atridas, Príamo e Aquiles, seria natural que Enéias concentrasse sua atenção sobre o rei de Tróia.

A sequiência desse verso conjuga-se com o 462 para formar um célebre passo da Eneida: Sunt hic etiam sua praemia laudi; / sunt lacrimae rerum et mentem mortalia tangunt.

\footnotetext{
${ }^{196}$ Esse verso contém personagens que simbolizam a querela instigadora da cólera de Aquiles e o conflito entre gregos e troianos; com isso, consegue materializar motivos do poema, favorecendo uma representação figurada. 197 A. Barchiesi (1999, p. 334) também reconhece esse duplo sentido.

${ }^{198}$ Cf. ALEXANDER, 1954; FEDER, 1954; STANLEY, 1965.
} 
Há muito se debate se a passagem concerne à situação particular de Enéias ou à sorte da humanidade.

Para Sérvio (ad I, v. 461), ao penetrar no templo, Enéias estaria preocupado com os modos cartagineses, temendo a recepção que o aguardava (o termo timorem do verso 450 corrobora essa idéia); contudo, ao ver pinturas, sentiria seu temor se dissipar (omnis Aeneae sollicitudo de moribus Afrorum est, quam nunc picturae contemplatione deponit), pois seriam indício de que tal povo tanto cultuaria a virtude quanto sentiria compaixão pelo padecimento humano (Qui enim bella depingunt, et uirtutem diligunt et miseratione tanguntur). Daí decorreria a afirmação feita no verso 463: Solue metus. Isso equivale a dizer que Enéias reconhece nas pinturas um sinal de que se acha em terras de um povo civilizado, dotado de humanidade e de cultura. Em consequiência, o hic etiam significaria "aqui também (em Cartago)". Sérvio equipara laudi a uirtuti e mortalia a aduersa; com isso, o verso 461 corresponderia a et uirtutem diligunt e o 462 a et miseratione tanguntur - ficando ausente um comentário específico para lacrimae rerum. Sérvio então aventa uma interpretação desses versos inteiramente vinculada à situação na qual Enéias se encontra em Cartago ${ }^{199}$.

James Henry (1873, p. 705-707) julga de forma diferente o verso 462. Para ele, não haveria uma coordenação entre as orações iniciadas por sunt nos versos 461 e 462; independente, este último não aludiria apenas ao caso particular de Enéias, mas instituiria uma reflexão universal, com o seguinte sentido (p. 705):

Lágrimas são universais (RERUM), pertencem à constituição da natureza; e os males dos mortais (MORTALIA) comovem o coração humano. ${ }^{200^{\circ}}$

Essas duas interpretações ainda hoje orientam os debates em torno desses versos ${ }^{201}$. Participando da contenda, Lillian Feder (1953-1954, p. 201) expressa um argumento conseqüente contra um aspecto da interpretação de Henry: uma vez que as imagens deslindam tamanho sofrimento causado pelos gregos aos troianos, seria improvável atribuir à expressão lacrimae rerum o valor de uma compaixão universal pelas dores humanas. Feder então

\footnotetext{
${ }^{199}$ Austin (ad I, v. 461-462) segue de perto a análise de Sérvio e acrescenta que o sentido de mortalia ajuda a definir o de rerum.

200 "Tears are universal (RERUM), belong to the constitution of nature, and the evils of mortality (MORTALIA) move the human heart".

${ }^{201}$ Stanley (1965) faz um levantamento das tendências tomadas por tais discussões até sua época, mas sempre ligando a expressão En Priamus à imagem do cadáver de Heitor.
} 
compreende esses versos de forma trágica: seria a tragédia humana ali representada, não a compaixão.

Reflexão a respeito da situação de Enéias, da compaixão universal, da tragédia humana... os versos 461 e 462 inspiram leituras diversas. A essas se une a que segue, levando em consideração todo o contexto analítico dessa primeira imagem. Dado que nesse episódio Virgílio também discute poesia (em particular a épica), esses versos serão examinados em função dos dois planos de sentido em apreço, um relativo ao enredo da Eneida e um metapoético.

No que tange ao enredo, acata-se em grande parte a interpretação de Sérvio: a preocupação de Enéias com o acolhimento cartaginês é determinante para a compreensão da passagem; a percepção das pinturas leva Enéias a inferir que tal povo seja civilizado, sensível à arte e, em conseqüência, à sorte humana; as duas orações introduzidas por sunt estão coordenadas. Destarte, Sunt hic etiam sua praemia laudi, sunt lacrimae rerum significaria "aqui também (em Cartago) há o reconhecimento para os feitos dignos de louvor, há as lágrimas dos acontecimentos". Trata-se de uma constatação reconfortante para o herói, ainda mais porque é proferida logo após o En Priamus, expressão direcionadora do ponto de vista: para Enéias, as noções de reconhecimento da virtude e sensibilidade ao sofrimento humano dizem respeito aos troianos, aqui simbolizados por Príamo - opondo-se ao saeuom Achillem. Por outro lado, afastando-se de Sérvio e aproximando-se de Henry, considera-se a expressão et mentem mortalia tangunt uma asserção universal decorrente do exemplo visto em Cartago; depois da referida constatação, vem a afirmativa: "Com efeito, as questões humanas tocam o espírito". De um ponto de vista retórico, através de um processo indutivo, Enéias passa da constatação de um fato a uma emissão conclusiva.

Quanto ao plano metapoético, tomemos o substantivo laus com o sentido de "elogio" (normalmente pronunciado); nesse contexto, conotaria o "elogio das façanhas" implementado pela poesia épica (e aqui retratado pela pintura). Assim, Sunt hic etiam sua praemia laudi significaria: “Aqui também (em Cartago), o elogio das façanhas (a poesia épica, a pintura) recebe sua recompensa". Em conseqüência, sunt lacrimae rerum também faria alusão ao efeito provocado por tal elogio (artístico) - como as lágrimas de Odisseu ante as canções de Demódoco, as de Enéias ante as pinturas... Eis um efeito estético, o qual se estende ao sentido de et mentem mortalia tangunt: o laus epicus amplia o poder de comoção dos fatos humanos. 
Sobre Odisseu e Enéias, que vivenciaram os eventos retratados pela arte (do aedo, dos pintores), tal efeito é ainda mais forte, despertando a memória. Após discutir a elaboração e a transmissão da poesia épica, Virgílio então põe em pauta efeitos produzidos no receptor.

E se chega ao verso final das sensações emitidas por Enéias diante da primeira imagem: Solue metus; feret haec aliquam tibi fama salutem (v. 463). Agora é o próprio Enéias quem emprega o termo fama. Com isso, coadunam-se o plano metapoético e o do enredo, e se arremata o que vem sendo discutido: não há razão para medo, pois a fama (virtude e sofrimento) troiana naquelas terras, proporcionada pela arte (no caso, o laus epicus e a pintura), há de conferir alguma forma de salvação. Esse verso também evoca as expressões timorem leniit e sperare salutem dos versos 450 e 451 e instiga um paralelo entre os sujeitos de leniit e feret: a noua res pode ser identificada com haec fama, ou seja, o fato inesperado e alvissareiro é a fama da guerra de Tróia e de Enéias. Mais tarde, as expressões aliquam salutem e solue metus se concretizam em razão dessa fama, quando Dido recebe os troianos e lhes diz soluite corde metum (v. 562)... A arte realmente é testemunho de humanidade e salva do esquecimento.

Depois da reação de Enéias, dois versos fazem uma transição para a retomada da contemplação do mural; desses, o 464 merece uma atenção especial: Sic ait atque animum pictura pascit inani. A primeira questão polêmica diz respeito ao significado do adjetivo inani, geralmente traduzido por "vã". Ora, em face dos efeitos produzidos pelas pinturas em Enéias e das funções por elas desempenhadas no poema, qualificá-las de "vãs" seria, no mínimo, incoerente. Julga-se, pois, que inani signifique "vazio" nessa circunstância - assim como no verso 476 do canto II (referindo-se ao carro vazio de Troilo) e no 304 do canto III (referindo-se ao túmulo vazio de Heitor no Epiro). Pode-se aprimorar essa significação através de uma análise mais profunda do verso, fundamentada em uma passagem do Fedro (274b-277a), de Platão.

Quando Theuth exalta sua invenção da escrita, julgando-a algo que fornecerá aos egípcios mais conhecimento, mais ciência e mais memória, julgando-a enfim o remédio da ciência e da memória (274e), o rei Tamos a critica, pois estima que favorecerá o esquecimento: confiando na escrita, os homens descuraram a memória (275a). Em seguida, o rei afirma que Theuth descobriu não o remédio da memória, mas o da rememoração, da mnemônica (275a). A escrita, então, irrompe aqui como um instrumento para despertar a 
memória. Pouco depois, Sócrates aproxima a escrita da pintura ${ }^{202}$ (275d-276a): os seres pintados parecem vivos, mas não respondem, permanecem imóveis, sem vida... sem alma; um texto escrito parece falar, mas não responde quando é interrogado, diz sempre a mesma coisa, precisa de seu criador para replicar.

Dessa reflexão, interessa especialmente o que toca a pintura. Seguindo a aproximação feita por Sócrates, uma aplicação do pensamento do rei Tamos a respeito da escrita à pintura, à luz da teoria da arte da memória ${ }^{203}$, leva à conclusão de que, na época de Virgílio, a pintura, muito mais do que a escrita, funcionava como um instrumento para despertar a memória. Com base nesse raciocínio, faz-se uma leitura do verso 464.

Tomando a pintura como instrumento para reavivar a memória, a frase animum $^{204}$ pictura pascit poderia ser lida da seguinte forma: "apascenta a mente com a pintura" (ou, de forma platônica, "realimenta a memória com a pintura").

Nesse contexto, reavalie-se o adjetivo inani. No verso vem à tona o seguinte paralelo: animum (de Enéias) opõe-se a inani (da pintura). Do ponto de vista platônico, a pintura é inanis, ou seja, vazia, sem alma, estática, mas não "vã" - Platão conhece bem o "perigoso" poder estético da pintura, da arte (República, X). Por conseguinte, a frase animum pictura pascit inani poderia receber esta tradução: "apascenta a mente com a pintura vazia" (ou, de forma platônica, "realimenta a memória com a pintura sem vida").

Nessa transição, prefigura-se, pois, a função mnemônica das imagens, fundamental para o episódio (como veremos ao longo deste capítulo)... e para esta tese.

Reunindo as análises espalhadas, afloram as seguintes ilações: a primeira imagem alude ao proêmio da Ilíada e à querela entre Aquiles e Agamêmnon; a parada no curso contemplativo das pinturas, na qual se insere uma reação de Enéias, é estratégica, tem por finalidade evidenciar o ponto de vista troiano, o papel da arte em relação ao temor de Enéias, o sentido metapoético do episódio e o despertar da memória do herói. O terreno agora está preparado para a apresentação das demais pinturas.

\section{II.1.2 - Imagens II e III (v. 466-468)}

Namque uidebat uti bellantes Pergama circum

\footnotetext{
202 Ocorre uma aproximação também no Timeu (19bc).

${ }^{203}$ Discutida na terceira seção deste capítulo.

${ }^{204}$ No livro III do De Rerum Natura, animus é definido como a sede do pensamento, da memória (Primum animum dico, mentem quem saepe uocamus, v. 94).
} 
hac fugerent Grai, premeret Troiana iuuentus,

hac Phryges, instaret curru cristatus Achilles.

Pois via os combatentes ao redor de Pérgamo: gregos fugindo aqui, no encalço jovens teucros; frígios ali, de carro atrás cristado Aquiles.

De forma coerente, após evocar com a primeira imagem o último verso do proêmio da Ilíada e todo o princípio desencadeador dessa epopéia, a Eneida propõe um "resumo" de duas ações do poema homérico em função do seguinte princípio: Aquiles ausente dos combates Aquiles de volta aos combates.

Knauer (1981, p. 885-886) reitera essas duas ações principais da Ilíada. A primeira liga-se a Helena: iniciada no canto II, esta ação, em princípio, não diz respeito a Aquiles. A segunda liga-se à morte de Pátroclo: essa começa no canto XVI e toca diretamente Aquiles, fornecendo-lhe uma razão decisiva para retornar às batalhas, o que acontece a partir do canto $\mathrm{XVIII}^{205}$.

Paratore (ad I, v. 467 e 468) também aponta tal elaboração (com uma pequena diferença quanto à extensão das ações no poema homérico): para ele, o verso 467 representaria a situação do canto IV ao XVII da Ilíada, quando os troianos resistem bem e, graças à retirada de Aquiles, chegam a vencer combates; o verso 468 representaria a situação a partir do canto XVIII, com o retorno de Aquiles após a morte de Pátroclo e o desencadear da vitória grega.

Do exame das três primeiras imagens, constata-se que todas aludem à Ilíada e que Virgílio estudou a estruturação desse poema homérico e procurou representá-la no mural (a imagem I corresponde ao proêmio e ao canto I da Ilíada; a II, aos cantos II-XVII; a III aos cantos XVIII-XXIV).

II.1.3 - Imagem IV (v. 469-473)

Nec procul hinc Rhesi niueis tentoria uelis adgnoscit lacrimans, primo quae prodita somno Tydides multa uastabat caede cruentus, ardentisque auertit equos in castra prius quam pabula gustassent Troiae Xanthumque bibissent.

\footnotetext{
${ }^{205}$ De acordo com Knauer (1981, p. 886), Virgílio teria reconhecido tais ações e as utilizado para estruturar a suposta parte "iliádica" de seu épico: o canto II da Ilíada seria o fundamento para o canto VII da Eneida; o XVIII e o princípio do XIX da Ilíada proveriam as bases para o VIII da Eneida; o XVI da Ilíada, para o X da Eneida.
} 


\begin{abstract}
Não distante de lá, de Reso as níveas tendas vê em pranto: traídas no primeiro sono, o tidida cruel as devastava aos golpes... E ao campo aqueu levou cavalos bravos antes que do pasto provassem e do Xanto em Tróia.
\end{abstract}

Essa representação do episódio de Reso evoca o canto X da Ilíada (v. 477-514).

Atente-se de início à divergência entre os tempos dos verbos uastabat e auertit, geradora de dúvidas quanto à presença do roubo dos cavalos na imagem. Putnam (1998, p. 29) acredita que tal mudança de tempo significaria a ausência do roubo, o qual consistiria em um comentário do narrador dirigido à memória que Enéias e o receptor têm de tal episódio. Williams (1960, p. 151) corrobora essa opinião ao afirmar que auertit, no perfectum, indica um elemento não presente na imagem. Ademais, não se menciona Ulisses, o responsável pelo roubo dos cavalos na Ilíada.

Embora não esteja representado, o roubo dos cavalos faz alusão a um oráculo segundo o qual Tróia não poderia ser vencida se de seus campos pastassem e de sua água bebessem os cavalos de Reso. Esse oráculo não figura no texto homérico nem na peça que Eurípides

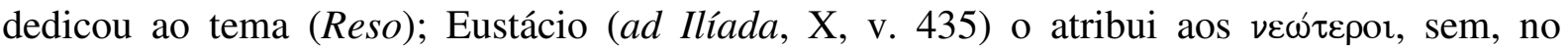
entanto, identificá-los ${ }^{206}$. Sérvio também o refere (ad I, v. 469): Abductique sunt equi, quibus pendebant fata Troiana, ut, si pabulo Troiano usi essent uel de Xantho Troiae fluuio bibissent, Troia perire non posset.

Verifica-se, pois, que Virgílio trabalhou com outras fontes além da Ilíada para elaborar essa imagem. No entanto, ainda que os $\nu \varepsilon \omega \tau \varepsilon \rho \rho$ tenham abordado a figura de Reso e desenvolvido o tema do oráculo, tal episódio pertence propriamente à Ilíada na repartição da trama da guerra de Tróia entre os poemas do ciclo troiano. Isso acrescenta um dado importante à tese segundo a qual a cena representaria apenas a ação de Diomedes: o roubo dos cavalos adquire uma importância maior graças ao oráculo, que não é abordado na Ilíada, mas que é fundamental para a Eneida; assim, a imagem em si evocaria a Ilíada, poema para o qual o feito de Diomedes é muito mais significativo ${ }^{207}$, e o narrador introduziria o comentário do roubo dos cavalos, significativo para a Eneida, para Enéias. Aliás, o verso que cita os cavalos

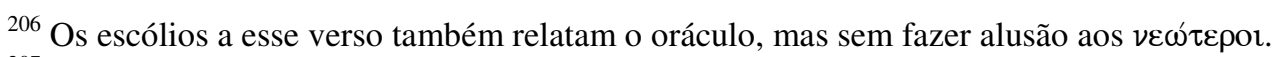

${ }^{207}$ Com efeito, entre as possíveis causas da ausência de Ulisses na imagem, Sérvio (ad I, v. 471) chega a indicar a tarefa "menos digna" que o guerreiro desempenhou nessa expedição: et bene Vlixen celat... aut quia, secundum Homerum, occidente Diomede cadauera Vlixes trahebat.
} 
é singular: ardentisque auertit equos in castra, prius quam. O termo equos é realçado pelo uso menos comum da cesura trocaica.

Nesse episódio, a expressão primo somno também é digna de um comentário. No contexto, adquire contornos de um descuido fatal face às insídias gregas; e seu significado amplia-se quando se estabelece um diálogo entre ela e duas passagens do canto seguinte.

No canto II, o mesmo descuido se verifica para Tróia no momento em que os gregos saem do cavalo de madeira: Inuadunt urbem somno uinoque sepultam (v. 265) ${ }^{208}$. Como Reso e seus homens, sepultos no sono, possibilitaram a emboscada de Diomedes e Ulisses, Tróia, sepulta em sono e vinho, permitiu o êxito do embuste do cavalo de madeira (esse estado da cidade também desvaloriza a vitória grega).

Logo em seguida, passa-se do sono da cidade ao sono de Enéias: Tempus erat, quo prima quies mortalibus aegris (II, v. 268). Trata-se do começo do episódio em que Heitor aparece em sonhos a Enéias e lhe revela que nada mais se pode por Tróia, que deve partir com os objetos sagrados e os penates, para os quais deve procurar outra cidade. Ao contrário de Reso e Tróia, o sono não sepulta Enéias; Heitor o desperta, justifica sua "fuga" e lhe confia uma missão ${ }^{209}$. Sobre Enéias pesa sempre o fardo inglório da fuga, com o qual Virgílio é obrigado a lidar; assim, à expressão primo somno da pintura de Reso também se liga a prima quies de Enéias.

Destarte, representando apenas a ação e Diomedes, essa pintura atinge três fins: evoca propriamente a Ilíada, ressalta uma insídia grega e relembra um dos oráculos ligados à queda de Tróia.

\section{II.1.4 - Imagem V (v. 474-478)}

Parte alia fugiens amissis Troilus armis, infelix puer atque impar congressus Achilli, fertur equis curruque haeret resupinus inani, lora tenens tamen; huic ceruixque comaeque trahuntur per terram, et uersa puluis inscribitur hasta.

\footnotetext{
${ }^{208}$ Este verso inspira-se provavelmente em um dos Annales de Ênio: Nunc hostes uino domiti somnoque sepulti (WARMINGTON, 1956, fr. 294). Em seu comentário a esse verso da Eneida, Austin (ad II, v. 265) expõe algumas repercussões da expressão uino somnoque sepulti na literatura latina. O termo sepultam, de certa forma, antecipa a morte da cidade.

${ }^{209}$ Tal missão se relaciona com o anúncio feito na Ilíada (XX, v. 302-308), comentado no capítulo anterior, ao longo do estudo do Saque de Ílion; esse assunto é retomado na análise da imagem VIII (II.1.6) e na segunda parte deste capítulo.
} 
Em outra parte, Troilo em fuga sem as armas; sem sorte e aquém, o jovem combateu Aquiles; cavalos puxam-no acostado ao carro inane, retém no entanto as rédeas; coma e nuca rasgam a terra, e a lança inversa escreve na poeira.

Como observado na introdução deste capítulo, a expressão parte alia constitui um índice da abertura de uma nova série de pinturas. Austin (ad I, v. 474) nela reconhece uma fórmula descritiva de emprego recorrente ${ }^{210}$.

A descrição da imagem ocupa os versos 474, 476, 477 e 478, delineada com riqueza de detalhes e formas verbais que concedem à cena dinamicidade - a $\dot{\varepsilon} \nu \dot{\varepsilon} \rho \gamma \varepsilon 1 \alpha$ preconizada por Aristóteles para as imagens (Retórica, XI, 1411b-1412a). Putnam (1998, p. 31) realça o fato de termos aqui mais objetividade descritiva e menos emotividade.

As expressões amissis armis e congressus indicariam eventos anteriores à cena que Enéias contempla. No primeiro capítulo (estudo dos Cantos Cíprios), soubemos haver poucas fontes literárias significativas anteriores a Virgílio para esse episódio: uma menção na Ilíada (XXIV, v. 257) e uma peça (perdida) de Sófocles, Troilo.

Segundo Williams (1960, p. 148), essa descrição teria como modelos uma passagem da Electra (v. 746-763) ${ }^{211}$, de Sófocles, uma do Hipólito (v. 1236-1237) ${ }^{212}$, de Eurípides, e principalmente a descrição do arrastar do corpo de Heitor na Ilíada (XXII, v. 401-403), de onde vem o verso huic ceruixque comaeque trahuntur / per terram.

Acredita-se em geral que essa imagem represente o desfecho de um combate entre Aquiles e Troilo, ao longo do qual o filho de Príamo perde suas armas (amissis armis) e é arrastado por seu carro, sem vida, trespassado pela lança de Aquiles, a qual risca o chão. Sérvio muito contribui para tal interpretação: apoiando-se no termo resupinus, questiona como Troilo poderia segurar uma lança e disso depreende que a hasta citada seja a de Aquiles, a qual atravessou o peito do jovem troiano e cuja ponta de ferro, saindo pelas costas, riscaria o chão; para ele, Troilo estaria morto ('lora tenes tamen' quamquam mortuus, ad v. 477); e, para solver o problema do sentido de uersa, toma tal termo como sendo um particípio

\footnotetext{
210 Aparece, por exemplo, em Cícero (Arati Phaenomena, fr. 34, v. 367), Catulo (LXIV, v. 251), Virgílio (Eneida, VIII, v. 433 e 682) e Manílio (Astronomica, I, v. 319).

${ }^{211}$ Narração da corrida de carros durante a qual Orestes deixa escapar a rédea da mão esquerda e sofre um acidente fatal, cuja descrição assemelha-se à do episódio de Troilo.

${ }^{212}$ Passagem na qual os condutores são arrastados por seus carros. Austin (ad I, v. 476) também aceita esses versos do Hipólito como possível modelo.
} 
do verbo uerro, assim hasta uersa seria "lança arrastada" ("uersa' tracta), e não "lança invertida".

Williams (1960, p. 145-148) propõe uma reinterpretação dessa imagem. Inicialmente, afirma que os críticos mais recentes recusam a idéia de que a hasta seja a de Aquiles e apresenta alguns argumentos para tal posicionamento: antes de tudo, o texto da Eneida não fornece indício de que se trate da hasta de Aquiles; uersa viria de fato do verbo uerto, como se verifica no canto IX da Eneida (v. 609-610), em que vaqueiros usam a lança invertida (uersa hasta) para tanger o gado; com isso, o referencial para indicar a inversão passa a ser Troilo, invertida em relação a ele; enfim, considera não haver motivo para se afirmar que a hasta de Aquiles estaria uersa. Quanto à expressão armis amissis, Williams diz que vários críticos crêem que se refira apenas ao escudo, ainda admitindo que se trate de um combate armado. Em meio a essa revisão do assunto, Williams pergunta que razão existiria na passagem de Virgílio para se pensar em combate armado. Para ele, armis corresponderia às armas defensivas (sua "armadura"): escudo, elmo e grevas - ao mostrar a cabeça e o cabelo de Troilo arrastados pelo chão, o texto insinuaria justamente a ausência do elmo. Troilo não estaria usando um elmo e obviamente não o perdeu durante um combate armado com Aquiles; na verdade, estaria desarmado ao encontrar o pelida. Por quê? Como perdeu suas armas? Após comentar representações plásticas desse episódio (referidas no capítulo I, estudo dos Cantos Cíprios), ressalta uma novidade no texto de Virgílio: Troilo aparece em um carro, não em um cavalo, como nas representações pictóricas e referências literárias anteriores. Esse detalhe corresponderia a mais uma influência do episódio de Heitor arrastado por Aquiles. Apesar dessa diferença, Virgílio seguiria a tradicional história da emboscada e daria indícios de que o jovem não saiu de Tróia com o intuito de enfrentar Aquiles (p. 147): a ausência de um auriga para o carro, pois Troilo segura as rédeas (lora tenens tamen), denunciaria que não saiu com o propósito de combater ${ }^{213}$ e que, por infelicidade, encontrou Aquiles - infelix puer refletiria justamente essa falta de sorte, e não o fato de que se reputasse capaz de medir-se com Aquiles. Um argumento importante seria o seguinte: segundo um oráculo, a morte de Troilo significaria a queda de Tróia; seria então muita imprudência ele enfrentar deliberadamente Aquiles. Depois de refutar a idéia geral em torno dessa imagem, Williams propõe uma reinterpretação: em um momento anterior à cena pintada no templo, Troilo teria

${ }^{213}$ O termo congressus significaria apenas "encontrou" (p. 147, n. 5). 
sido apanhado por Aquiles enquanto realizava alguma atividade (não se sabe qual) sem usar suas armas defensivas; teria saído vestido com sua "armadura" para exercitar seus cavalos; sentindo-se seguro, teria retirado suas armas e então teria sido emboscado por Aquiles; logo, a imagem representaria o momento em que procura fugir do grego, tendo deixado as armas para trás; na fuga, teria caído para trás, talvez ferido, talvez porque um de seus cavalos, ferido, tenha se descontrolado; mas ainda segura as rédeas, tentando controlar a situação apesar de tudo (tamen) - como atesta a Ilíada (XXIV, v. 257), sua habilidade é a de controlar cavalos. Em conclusão, ainda estaria vivo no momento representado. Com isso, afirma não existir contradição entre o fato de preservar sua hasta e a expressão amissis armis: ou Troilo teve apenas o tempo de pegar sua lança ao perceber Aquiles, ou, o que Williams julga mais provável, usava a lança invertida (uersa) como um bastão para instigar os cavalos (como na Eneida IX, v. 609-610). Destarte, uma mão seguraria a lança e a outra as rédeas; caindo, a ponta da lança riscaria o chão.

Contudo, o sentido de hasta uersa não fornece um argumento tão sólido à ausência de combate. Na verdade, o modo de empunhar o cabo da lança seria o mesmo tanto para atirá-la contra um inimigo quanto para instigar animais, o que mudaria seria a direção da ponta. $\mathrm{O}$ problema é que a cena já mostra o troiano caído, com o adjetivo uersa sinalando que a ponta está para trás em relação a ele, riscando o chão. Ora, assim descrita, tal situação pode resultar indiferentemente dos dois casos: quer Troilo a empunhasse para combater, quer a empunhasse para tanger os cavalos, ao cair, direcionaria a ponta da lança para o chão em busca de apoio. Continuamos sem saber como ele a usava antes de cair.

Austin (ad I, v. 474) também crê que a hasta uersa seja a de Troilo e levanta uma hipótese interessante: as armas caídas (amissis armis) provavelmente apareceriam na imagem, no chão. Quanto a um combate entre os guerreiros, defende a idéia de que Troilo ter-se-ia batido com Aquiles antes de perder suas armas. Para amparar sua opinião, evoca outra ocorrência de congressus na Eneida (V, v. 809) com o sentido de combater: Pelidae tunc ego forti / congressum Aenean nec dis nec uiribus aequis / nube caua rapui (v. 808-810, trata-se do episódio em que Netuno relembra a Vênus ter uma vez salvo Enéias das armas de Aquiles - mais uma alusão ao canto XX da Ilíada). Tal evocação proporciona outro argumento a favor da tese de um combate: Troilo é colocado em paralelo com Enéias, que enfrentou Aquiles e precisou fugir por se encontrar em inferioridade. Isso não significa dizer que o filho de 
Príamo teria saído de Tróia para combater Aquiles, apenas que teria havido entre os dois uma contenda antes da fuga.

Tais ensaios de interpretação teriam um resultado muito mais significativo se dispuséssemos das fontes (em especial dos Cantos Cíprios) das quais Virgílio se serviu para compor esse episódio. Além de batalhas interpretativas, a imagem de Troilo suscita a investigação de outro aspecto: um oráculo ligado à queda de Tróia.

Como vimos no estudo da Pequena Ilíada, Plauto (Bacchides, v. 953-955) cita a morte de Troilo como um dos fata relacionados com o excídio de Tróia, ao lado do roubo do paládio e da destruição do limiar superior de uma porta frígia (para a entrada do cavalo de madeira $)^{214}$. O oráculo de Troilo aparece com mais precisão no texto Mythographi Vaticani (Le Premier Mythographe du Vatican, III, 8, 2): Cui dictum erat quod, si ad annos uiginti peruenisset, Troia euerti non potuisset.

Destarte, após evocar o oráculo de Reso, Virgílio sugere o de Troilo.

Como se viu no capítulo primeiro, a valorização de oráculos constitui um traço característico dos épicos cíclicos - traço que, aliás, os diferencia dos poemas homéricos. $\mathrm{Na}$ Pequena Ilíada, por exemplo, oráculos ligados à queda de Tróia multiplicam-se por ocasião da captura de Heleno: necessidade do arco e das flechas de Héracles (e a consequiente reintegração de Filoctetes), a recuperação dos ossos de Pélops, a agregação de Neoptólemo ao exército, o roubo do Paládio. A esses se somam os dois outros informados por Plauto e o oráculo relacionado com Reso. Não se sabe como tais oráculos chegaram até Virgílio; sabese, todavia, que, ao conceder-lhes importância, o poeta demonstra seguir de perto as epopéias perdidas do ciclo troiano.

Em conclusão, essa primeira imagem da segunda série pertence propriamente aos episódios dos Cantos Cíprios e evoca um dos oráculos que garantiam a salvação de Tróia.

\section{II.1.5 - Imagem VI (v. 479-482)}

\section{Interea ad templum non aequae Palladis ibant crinibus Iliades passis peplumque ferebant suppliciter, tristes et tunsae pectora palmis; diua solo fixos oculos auersa tenebat.}

Nisso ao templo de Palas não propícia iam

\footnotetext{
${ }^{214}$ Estudando a questão, Austin (ad I, 474) informa que esses fata não fariam parte da peça de Menandro ( $\Delta$ i⿳ $\dot{\varepsilon} \xi \alpha \pi \alpha \tau \hat{\omega} v)$ que serve de modelo a Plauto.
} 
troianas, solta a cabeleira, o peplo em mãos, súplices, tristes, percutindo o peito as palmas; avessa, a deusa fixo o olhar no chão mantinha.

No sexto canto da Ilíada (v. 73-101), em meio à aristia de Diomedes, o adivinho Heleno reanima Enéias e Heitor, sobre os quais recai o peso da batalha, e diz a este que retorne ao palácio e peça a sua mãe que vá ao templo de Atena com outras veneráveis matronas e ofereça à deusa sacrifícios e o maior e mais belo peplo existente no palácio, a fim de que esta afaste do combate o valente filho de Tideu. Chegando ao palácio, Heitor transmite a Hécuba as recomendações de Heleno (v. 242-285), as quais a rainha executa em seguida (v. 286-311). À execução das recomendações por Hécuba e pelas matronas troianas corresponde a imagem em apreço. Consolidando o elo entre as passagens dos dois poemas, o verso $482 \mathrm{da}$

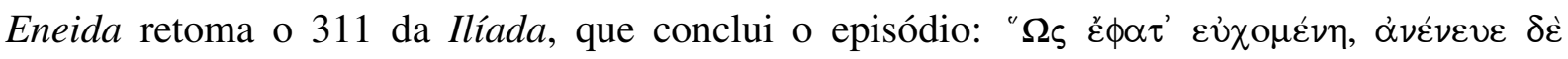
$\Pi \alpha \lambda \lambda \alpha \varsigma^{\prime}$ 'A $\theta \eta \eta \eta \eta$. Atena não atende ao pedido das troianas.

Um interessante detalhe deste episódio coloca em contato não apenas a Eneida e a Ilíada mas também os Cantos Cíprios: o peplo ( $\pi \dot{\varepsilon} \pi \lambda \mathrm{\jmath}$ ) escolhido por Hécuba (v. 294) fora confeccionado em Sídon, por mãos fenícias, e de lá trazido por Páris quando voltava de Esparta com Helena (trata-se do polêmico desvio por Sídon e do saque desta cidade discutidos no estudo dos Cantos Cíprios). Diante desse detalhe, Austin ( $a d$ I, v. 480) questiona se não seria essa origem fenícia o motivo que teria levado Dido a escolher tal evento para seu mural. Esse raciocínio suscita outra ilação significativa: Virgílio, que usou o texto da Ilíada para compor a cena, sugere que os artífices da rainha tenham usado "o ciclo troiano" para compor seu mural - esse procedimento ilustraria o uso de episódios de poemas épicos como fontes para pinturas.

Essa imagem toca ainda a participação de Atena nos episódios da morte de Heitor no canto XXII da Ilíada: inicialmente, a deusa rejeita a proposição de Zeus para salvar Heitor (v. 177-181); depois, auxilia Aquiles a matar Heitor (v. 214-305) ${ }^{215}$.

Uma reverberação dessa imagem atinge o canto II da Eneida (v. 588-620): a aversão de Atena à salvação de Tróia salienta-se no episódio em que Vênus revela a Enéias que a cidade cai não por culpa de Helena, nem de Páris, mas por inclemência de alguns deuses (diuon inclementia, v. 602), entre os quais aparece Atena sobre uma torre de Tróia.

\footnotetext{
${ }^{215}$ Tais episódios serão discutidos na parte II deste capítulo (II.2.2), quando explicitarão relações entre essa pintura e a seguinte.
} 
Examinando a imagem, Williams (1960, p. 149) acredita que, após a exibição de mortais (Reso e Troilo) vinculados aos fata da queda de Tróia, Atena representaria a encarnação divina desse destino funesto. Tal análise mostra-se bastante coerente: uma vez decidida a queda de Tróia no plano divino, nenhum mortal poderia evitá-la, nem mesmo o grande Heitor. Williams (p. 149, n. 2) ainda levanta a hipótese de essa pintura despertar uma associação mental com a profecia que liga a queda de Tróia ao roubo do paládio, evocado no canto II da Eneida pelo discurso enganador de Sínon. Na última parte desse discurso (v. 163171), Sínon conta aos troianos que toda a esperança de vitória grega residia no auxílio de Atena (Omnis spes Danaum et coepti fiducia belli / Palladis auxiliis semper stetit, v. 162163). A deusa, porém, teria sido ofendida quando Diomedes e Ulisses roubaram o paládio (auellere templo / Palladium, v. 165-166), ficando avessa à sorte grega (auersa deae mens, v. 170).

Auxílio dos gregos, Atena não se enfurece contra eles por ocasião do roubo do paládio, mas devido ao sacrilégio de Ájax filho de Oileu; e sua fúria somente se manifesta mais tarde, durante os retornos.

Ainda que seja inevitável, essa associação com o roubo do paládio não deve constituir o objetivo primeiro da pintura. Como vimos no capítulo I, a ação de Sínon constitui um episódio integrante da Pequena Ilíada ${ }^{216}$, portanto posterior aos acontecimentos da Ilíada. Consciente disso, Virgílio não o exploraria diretamente nessa imagem, o poeta na verdade desenvolve esse tema na composição do canto II, na qual se serve da Pequena Ilíada e do Saque de Ílion.

Em conclusão, ressaltemos o fato de termos aqui a fonte precisa à qual a Eneida se refere: uma passagem do canto VI da Ilíada. É interessante notar que os índices alusivos fornecidos pelo texto não deixam dúvidas: com retomada textual de um poema e evocação de outro, esses versos da Eneida põem em contato a Ilíada e os Cantos Cíprios e dialogam com os dois. Virgílio usa aqui um texto preciso para compor sua imagem, ocorreria o mesmo processo para outras imagens referentes a textos perdidos?

\section{II.1.6 - Imagem VII (v. 483-487)}

Ter circum Iliacos raptauerat Hectora muros exanimumque auro corpus uendebat Achilles.

\footnotetext{
${ }^{216}$ Recorde-se a discussão sobre a possível existência desse episódio no Saque de Ílion (capítulo I).
} 
Tum uero ingentem gemitum dat pectore ab imo, ut spolia, ut currus, utque ipsum corpus amici tendentemque manus Priamum conspexit inermis.

Três vezes arrastara Heitor em torno a Tróia e a ouro o corpo exânime vendia Aquiles. Então gemido ingente do imo peito arranca ao ver o espólio, o carro, o corpo até do amigo a ainda Príamo estendendo as mãos inermes.

Diante dessa pintura, Enéias volta a manifestar forte emoção. O verbo no mais-queperfeito (raptauerat) indica que a morte e o flagelo do corpo de Heitor ocorreram antes do momento representado: a cena mostraria apenas o instante da venda do cadáver por ouro ${ }^{217}$.

Quanto à fonte, nenhum texto conhecido reúne todos os detalhes da imagem, especialmente as voltas ao redor dos muros de Tróia e a venda do corpo por ouro.

Na Ilíada, Aquiles arrasta o cadáver de Heitor em duas passagens: no canto XXII (v. 396-404), Heitor é atado ao carro do pelida e arrastado para os barcos; no XXIV (v. 14-22), ao nascer o dia, Aquiles arrasta o cadáver de Heitor três vezes ao redor da tumba de Pátroclo. Portanto, a versão apresentada nessa pintura não corresponde exatamente à do poema homérico. De onde viria?

Ao abordar esse episódio na peça Ájax (v. 1029-1031), Sófocles refere o ultraje do cadáver (Heitor atado ao carro de Aquiles - com o cinturão que Ájax lhe dera - e assim arrastado, rasgado), mas nada acrescenta quanto às voltas ao redor dos muros. Entre os textos

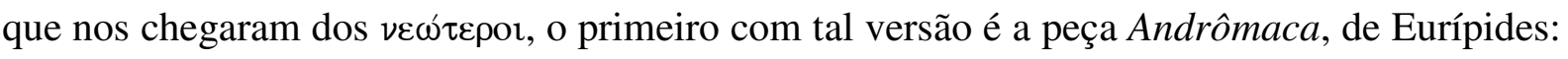
nos versos 107 e 108, Andrômaca diz que Heitor foi arrastado ao redor dos muros de Tróia, preso ao carro de Aquiles; no verso 399, menciona o ultraje, Heitor arrastado junto às rodas de um carro.

No que tange à venda do corpo de Heitor por ouro, o primeiro tratamento literário conhecido remonta a Ésquilo, em uma trilogia perdida supostamente composta das peças Myrmidones, Nereides e Phryges (siue Hectoris Redemptio) ${ }^{218}$ e datada da primeira metade do séc. V a. C. Nesta última, ocorreria a troca do cadáver de Heitor por ouro, como informa o texto de Ahrens (1864, p. 187): Tum vero mollior factus recordatione patris Achilles tandem permovetur, ut reddat auri aequo pondere repensum Hectorem patri. E escólios

\footnotetext{
${ }^{217}$ Cf. WILLIAMS, 1960, p. 151, e AUSTIN, $a d$ I, v. 483.

${ }^{218}$ Cf. AHRENS, 1864, p. 181-187.
} 
(DINDORFIUS e MAASS) ao verso 351 do canto XXII da Ilíada também confirmam a abordagem de tal tema por Ésquilo - com o editado por Dindorfius apresentando o seguinte

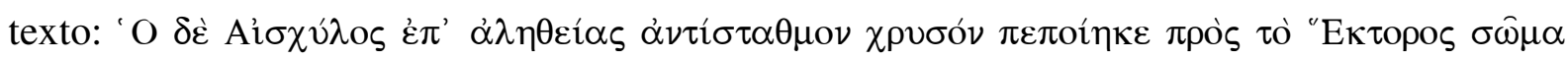
$\varepsilon \dot{\varepsilon} \Phi \pi v \xi \xi i v$. Para Stanley (1965, p. 271), Ésquilo teria literalmente desenvolvido em seu drama a idéia expressa pelos versos 349-353 do canto XXII da Ilíada.

Essa peça de Ésquilo também teria dado azo a representações figuradas do episódio do flagelo e da venda do cadáver de Heitor por ouro. Analisando um tablete de argila com um alto-relevo, proveniente da ilha Mélia, datado de cerca de 440 a. C., Graham (1958) e Carpenter (1997, fig. 319) nele reconhecem uma representação do resgate do corpo de Heitor por seu peso em ouro. Para Graham (1958, p. 315), esse esquema iconográfico deriva provavelmente da peça de Ésquilo ${ }^{219}$ :

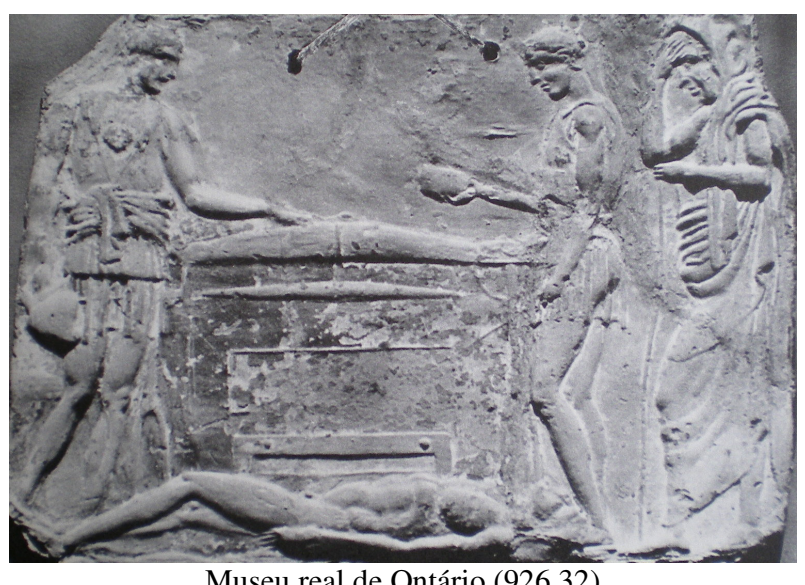

Graham (p. 315) informa ainda que, na Antigüidade tardia, o corpo realmente aparecia sobre o prato da balança; daí supõe que Virgílio tivesse isso em mente ao compor o verso 484.

Concordando com Graham, Stanley (1965, p. 271) acredita que a referida peça de Ésquilo seja a fonte das mais antigas representações iconográficas conhecidas da venda do cadáver de Heitor por ouro e a provável fonte literária da representação desse episódio na Eneida, mas com o intermédio das representações plásticas - Stanley (p. 270) avalia a descrição de Virgílio mais panorâmica do que narrativa, o que sugeriria ser seu modelo antes uma obra figurativa do que uma narração épica. Pouco depois, Stanley (p. 272) cita o comentário de Eustácio (VAN DER VALK, 1987) ao verso 351 do canto XXII da Ilíada,

\footnotetext{
${ }^{219}$ Carpenter apresenta duas outras representações do resgate do cadáver de Heitor: um relevo em bronze, proveniente de Olímpia, datado de 570 a. C. (fig. 317) e uma taça ática de figuras vermelhas datada de 520 a. C. (fig. 318). Nessas representações mais antigas, não há o tema da venda do cadáver por seu peso em ouro.
} 
segundo o qual autores posteriores a Homero descrevem o resgate de Heitor como um processo de troca de seu corpo por seu peso em ouro e que o mesmo teria acontecido com Aquiles após ser morto por Páris, como aparece no poema de Licofron (v. 269-273). Aliás, no

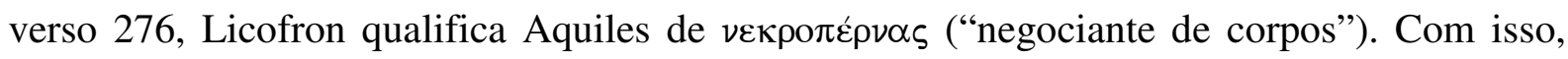
Stanley (p. 271, n. 16) estima que o peso do cadáver de Heitor em ouro tenha se tornado um motivo recorrente na literatura, como exemplifica uma peça de Plauto, Mercator (v. 488: Charinus: Achillem orabo, aurum ut mihi det, Hector qui expensus fuit.), e uma de Ênio, Hectoris Lytra, modelada na de Ésquilo.

$\mathrm{Na}$ verdade, Ênio teria trabalhado toda essa trilogia perdida de Ésquilo na tragédia Hectoris Lytra. E Higino aparentemente retoma tal peça na Fábula 106, também intitulada Hectoris Lytra. Considerando-se o conteúdo dessa fábula, acredita-se que a peça de Ênio abordaria eventos desde o ressentimento de Aquiles, advindo do caso Briseida, o qual o afasta do combate, até o resgate do cadáver de Heitor e os subseqüentes ritos funéreos. Na última parte da fábula, depois de Aquiles receber as armas confeccionadas por Vulcano, aparecem os dois principais eventos da imagem em apreço: as voltas em torno dos muros de Tróia (astrictumque ad currum traxit circa muros Troianorum) e a venda do cadáver por ouro (Priamus Iouis iussu duce Mercurio in castra Danaorum uenit et filii corpus auro repensum accepit). Em conseqüência, a peça de Ênio também se tornaria uma provável fonte para essa pintura. Tais acontecimentos já se encontrariam reunidos na peça de Ésquilo? É difícil saber. Todavia, a esse respeito, Warmington (1956, p. 273) supõe que Ênio tenha retrabalhado os modelos de Ésquilo incluindo detalhes da Ilíada, de modo a adaptar sua peça ao texto homérico.

Reforçando a idéia de uma influência de Ênio sobre Virgílio na composição desse episódio, Austin (ad I, v. 483) acrescenta que a escolha vocabular de Virgílio pode também derivar de uma peça de Ênio, Andrômaca: Vidi uidere quod me passa aegerrume / Hectorem curru quadriiugo raptarier (fr. 92 Warmington).

Retome-se nesse ponto a interessante hipótese de Kopff (1981, p. 930-931) apresentada no capítulo I (estudo do Etíope): a existência do episódio da morte de Heitor no princípio do Etíope. Em sua argumentação, alega em primeiro lugar que o tratamento concedido pela Eneida ao episódio não corresponde exatamente ao da Ilíada, aproximando-se mais daquele processado em tragédias (como se viu por intermédio de Ésquilo). Em seguida, 
aventa o fato de que a versão dos trágicos poderia provir, como normalmente acontece, de um épico cíclico (e, nesse caso, a fonte não seria a Ilíada). Por fím, cita a existência de três vasos homéricos com as mesmas três cenas ${ }^{220}$ : Príamo, suplicante, ajoelhado diante de Aquiles, Príamo recebendo Pentesiléia diante da tumba de Heitor e Aquiles lutando com Pentesiléia.

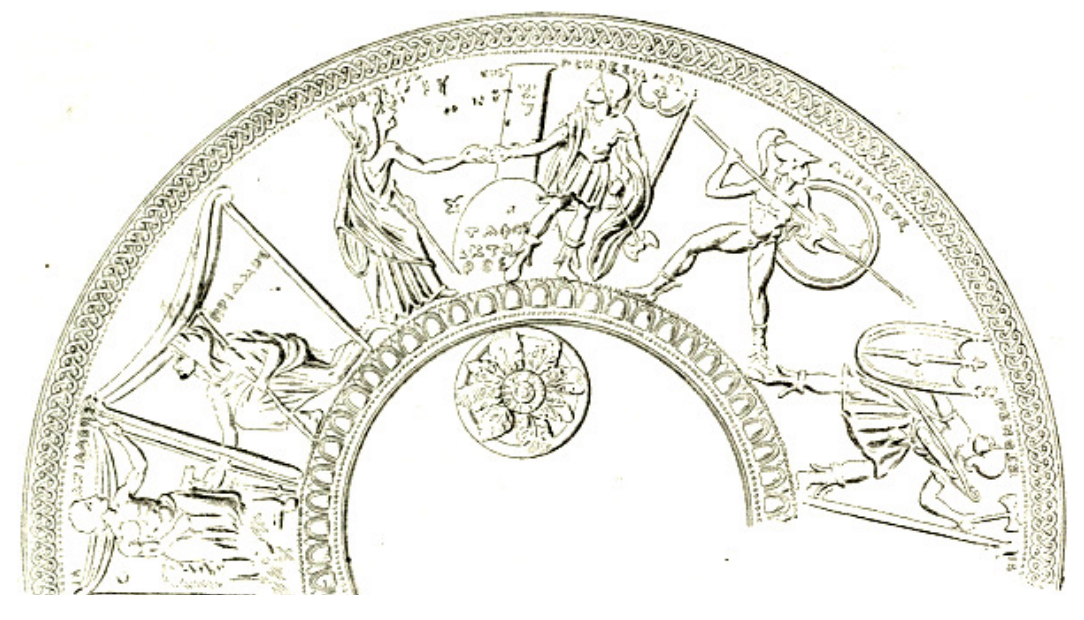

Antiquarium de Berlin, J. N. 3161

Em conseqüência, acredita que as três cenas dos vasos pertenceriam à mesma obra, o Etíope, e indicariam uma sequiência de acontecimentos do poema: a súplica de Príamo a Aquiles, que mutilava o corpo de Heitor arrastando-o ao redor dos muros de Tróia; a chegada de Pentesiléia; o combate entre esta e Aquiles.

Diante dessa hipótese, algumas considerações emergem. Admitindo que o episódio da morte de Heitor existisse no princípio do Etíope, teria sido suprimido posteriormente, uma vez que Proclus não o inclui no sumário desse épico. Tal supressão poderia ter acontecido quando os poemas do ciclo troiano foram editados em conjunto ou quando passaram a ser usados como "moldura" para edições dos poemas homéricos (como sugere Severyns, 1928b, p. 245), pois tal versão não apenas retoma um episódio já abordado na Ilíada mas também diverge da versão homérica em alguns aspectos. Isso significaria dizer que, se Virgílio realmente modelou sua pintura no Etíope, teria tido acesso ou à versão original desse épico, ou a uma versão cíclica com tal acontecimento, ou a uma iconografia do evento referindo-se a esse épico, ou no mínimo a uma informação de que esse poema originalmente principiava assim. O exame da imagem seguinte fornecerá outro argumento a favor dessa hipótese.

${ }^{220}$ ROBERT, 1890, Cap. III: “Ilias und Aithiopis", p. 21-29. 
Ao fim desse semear de discussões e hipóteses, os dados mais palpáveis colhidos seriam estes: a fonte literária conhecida mais próxima de Virgílio para a elaboração dessa imagem seria essa peça de Ênio Hectoris Lytra; as fontes literárias mais distantes conhecidas seriam as peças Phryges, de Ésquilo, e Andrômaca, de Eurípides; iconografias desse episódio devem ter chegado aos olhos de Virgílio. Enfim, não descartando a possibilidade de que o Etíope já desenvolvesse a versão apresentada nessa imagem, assim se configuraria o percurso:

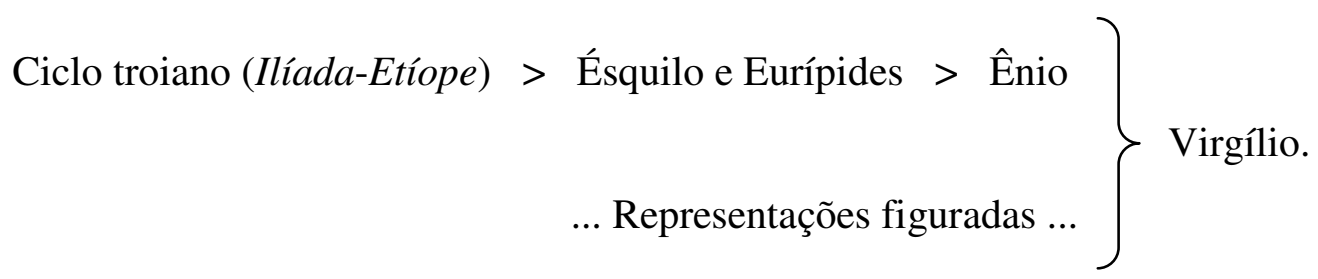

II.1.7 - Imagens VIII (v. 488), IX (v. 489) e X (v. 490-493)

$$
\begin{aligned}
& \text { Se quoque principibus permixtum adgnouit Achiuis } \\
& \text { Eoasque acies et nigri Memnonis arma. } \\
& \text { Ducit Amazonidum lunatis agmina peltis } \\
& \text { Penthesilea furens mediisque in milibus ardet, } \\
& \text { aurea subnectens exsertae cingula mammae, } \\
& \text { bellatrix, audetque uiris concurrere uirgo. } \\
& \text { A si também ao pé de aquivos chefes vê, } \\
& \text { gládios orientais, de Mêmnon negro as armas. } \\
& \text { Guia a tropa amazona de lunado escudo } \\
& \text { Pentesiléia em fúria e em meio a muitos arde, } \\
& \text { o áureo talim atado sob o seio nu; } \\
& \text { guerreira, contender com homens ousa a virgem. }
\end{aligned}
$$

Das três imagens finais, duas aludem explicitamente ao Etíope, a de Mêmnon e a de Pentesiléia. E, de acordo com a ordem dos episódios desse épico estudada no capítulo I, tais imagens revelam-se invertidas - discute-se essa inversão na segunda parte deste capítulo (II.2.2). No que diz respeito à imagem em que Enéias se vê misturado aos chefes aqueus, os estudiosos até agora não a vincularam a nenhuma fonte específica; a ela, portanto, consagra-se uma investigação.

Enéias vê a si e a Mêmnon, dois heróis que deveriam suprir a ausência de Heitor. Quanto à conjectura de inverossimilhança para esse reconhecimento, acredita-se que o nome 
das personagens deveria constar nas pinturas, como ocorre nos vasos ${ }^{221}$ - isso corrobora a idéia de que Virgílio também se serviu de fontes iconográficas para compor seu mural.

Uma hipótese apresentada para a significação do reconhecimento de Enéias traz à tona uma suposta traição do herói.

Logo na abertura do livro I de seu $A b$ urbe condita, Tito Lívio menciona um tratamento diferenciado concedido pelos gregos a Antenor e a Enéias durante o saque de Tróia, em virtude de deveres inerentes à hospitalidade (uetusti iure hospitii) e porque os dois sempre aconselharam os troianos a buscarem a paz e a devolverem Helena (quia pacis reddendaeque Helenae semper auctores fuerant).

Como se viu no capítulo anterior, por ocasião do estudo dos Cantos Cíprios, Apolodoro (Epítome, 3, 28-31) relata que Antenor salvou Odisseu e Menelau quando estes foram a Tróia reivindicar a devolução de Helena e dos bens de Esparta com ela levados. Na Ilíada, Antenor afirma ter hospedado os dois gregos aquando dessa embaixada (III, v. 207208) e mostra-se favorável a tal devolução (VII, v. 347-353). Discutindo a possível sobrevivência de Antenor graças à hospitalidade oferecida aos embaixadores gregos, Estrabão (Geografia, XIII, 1, 53) informa que, em um drama de Sófocles (fr. 11 RADT, atribuído à peça Ájax Lócrio), uma pele de leopardo encontrava-se na porta de entrada da casa de Antenor durante a tomada de Tróia, configurando uma identificação para que os gregos a poupassem. Pausânias (X, 27, 3), comentando a pintura de Polignoto na Lesche em Delfos, representando episódios do saque de Tróia, menciona a mesma história da pele de leopardo; e, no estudo da Pequena Ilíada, vimos que Pausânias (X, 26, 8) atribui ao poema de Lesques um episódio no qual Odisseu reconhece e salva um filho de Antenor, Helicáon, que havia sido ferido no combate noturno. No relato de Apolodoro (Epítome, 5, 21), Odisseu e Menelau reconhecem e salvam outro filho de Antenor, Glauco, em meio ao saque, enquanto este fugia para sua casa. Esses testemunhos falam de gratidão, não indicam qualquer perfídia; segundo Austin ( $a d$ I, v. 242), a idéia da traição de Antenor teria surgido no período alexandrino, tendo o poema de Licofron (v. 340-343) como sua primeira fonte conhecida.

Quanto ao caso de Enéias, nos épicos do ciclo troiano, até onde se sabe, não há referências a uma traição por ele perpetrada. Segundo Estrabão (Geografia, XIII, 1, 53), a referida peça de Sófocles, além da fuga de Antenor, abordava a de Enéias, o qual teria

${ }^{221}$ Cf. AUSTIN e PARATORE, $a d$ I, v. 488. 
navegado com um grupo de seguidores, Anquises e Ascânio; essa peça aproxima a salvação dos dois, todavia não é possível saber se uma traição era aventada. Na passagem de Apolodoro (Epítome, 5, 21) contendo a salvação de um filho de Antenor por Odisseu e Menelau, lê-se que os gregos teriam deixado Enéias partir com seu pai em respeito por sua $\varepsilon v ̉ \sigma \varepsilon ́ \beta \varepsilon ı \alpha$, equivalente à pietas latina. Dionísio de Halicarnasso comenta a traição de Enéias (Ant. Rom., I, 48, 3) - e a de Antenor (Ant. Rom., I, 46, 1). Informa que um historiador de nome Menecrates (provavelmente do séc. IV a. C) contava que Enéias teria recebido a permissão de partir de Tróia ileso e com sua família por ter ajudado os gregos a conquistar a cidade, a tirar Príamo do poder e que o troiano teria feito isso porque Páris o desprezava, não reconhecia suas prerrogativas.

Smith (1981, p. 33-34) estima que a versão apresentada por Menecrates, um lício, conterrâneo de Glauco e Sarpédon, tenha sido forjada para desvalorizar a vitória grega, a qual passaria a ser fruto de uma traição interna, não mais de superioridade - isso às expensas da honra de Enéias, que passa a ser visto como um dardânio invejoso, rancoroso. Para ele (p. 34), esse herói seria um alvo natural para aqueles que procurassem justificar o excídio de Tróia com uma traição, pois sobreviveu à queda da cidade e há na Ilíada passagens denotando uma querela entre ele e a casa de Príamo:

- no canto V (v, 259-273), narra-se o episódio dos cavalos dados por Zeus a Trós em compensação pelo arrebatamento de Ganimedes; ao invés de repartir com justiça tais cavalos entre os membros da família, Trós os concede apenas ao ramo reinante; para obter uma descendência desses animais, Anquises precisa fazê-los cruzar às escondidas com suas éguas - examinado essa passagem, Anderson (1997, p. 68-69) julga o roubo desse elemento de distinção (tal qual um cetro concedido por Zeus) uma simbologia da tomada do poder advinda com a dissolução do ramo de Ilo;

- no canto XIII (v. 459-461), Deífobo encontra Enéias ressentido por não ser honrado por Príamo;

- no canto XX (v. 178-183), Aquiles pergunta a Enéias por que avança para enfrentá-lo, se espera reinar sobre os troianos em caso de vitória, ocupando o lugar de Príamo.

Austin ( $a d$ I, v. 242) imagina que Sérvio tenha sido influenciado por uma variante com a traição. De fato, a primeira das duas possibilidades deslindadas por Sérvio para explicar o verso 488 associa Enéias e Antenor à idéia de traição, estabelecendo um liame entre o 
comentário desse verso e o do 242 (Antenor potuit) do canto I: 'se quoque principibus permixtum agnouit achiuis' aut latenter proditionem tangit, ut supra diximus ${ }^{222}$, ut excusatur ab ipso in secundo Iliaci cineres et cetera, aut uirtutem eius uult ostendere. Cabe aqui tecer uma consideração a respeito da última frase do relato que Dionísio de Halicarnasso atribui a

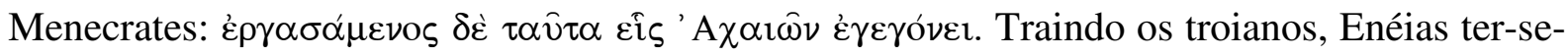
ia tornado "um dos aqueus" ( $\varepsilon i \varsigma$ 'A $\chi \alpha \imath \hat{\imath} v)$ ). Tais palavras curiosamente evocam o verso do reconhecimento de Enéias (principibus permixtum Achiuis). Essa semelhança talvez tenha contribuído para esse comentário de Sérvio ao verso 488.

Paratore ( $a d$ I, v. 488) não concorda que Virgílio faça menção à hipótese de traição. Realmente, não teria sentido aludir aqui a uma idéia de traição negada por todo o restante do poema.

A segunda possibilidade veiculada por Sérvio (aut uirtutem eius uult ostendere) nos conduz ao tratamento concedido a Enéias em poemas do ciclo troiano. Vimos no capítulo I que o canto XX da Ilíada desempenha um papel fundamental na lenda desse herói e que poemas do ciclo troiano teriam retomado anúncios feitos nesse canto: o Etíope teria abordado a participação de Enéias no grande combate pelo corpo de Aquiles; a Pequena Ilíada, possivelmente sua saída de Tróia como prisioneiro de Neoptólemo (com uma libertação posterior); o Saque de Ílion, sua salvação, a fuga da cidade após o episódio de Laocoonte.

Diante dessas especulações e do exposto no capítulo I, pode-se supor que o verso 488 reporte-se ao referido episódio do Etíope: Enéias estaria vendo uma pintura representando a morte de Aquiles, ou melhor, o grande combate pelo corpo de Aquiles; e, ao esquadrinhá-la, destacaria a percepção de si próprio - por outro ângulo, a pintura representaria um episódio fundamental do Etíope; todavia, diante dela, Virgílio faz seu herói destacar sua participação nesse momento relevante, o que evoca a advertência de Posídon no canto XX (v. 337-339): a glória guerreira prometida a Enéias após a morte de Aquiles.

Uma ponderação impõe-se: diante de uma pintura com uma intensa luta pelo corpo de Aquiles, da qual participam os grandes heróis ainda vivos, sobretudo do lado grego (principibus achiuis), o destaque de Enéias confere relevo à sobrevivência desse herói a Aquiles, ao contrário de Troilo, Heitor, Pentesiléia, Mêmnon... No momento da guerra representado na pintura, Enéias, o derradeiro grande baluarte dos troianos, deve suceder

${ }^{222}$ Referência ao comentário do verso 242. 
Heitor enquanto guerreiro. Essa idéia encontra reforço na colocação da imagem do reconhecimento logo em seguida à da morte de Heitor: de acordo com a advertência de Posídon (XX, v. 337-339), Enéias deveria tomar a frente nos combates somente após a morte de Aquiles; na imagem da luta pelo corpo de Aquiles, Enéias então pode reconhecer-se sucessor de Heitor enquanto guerreiro.

Um exame dessa passagem levando em consideração não o momento representado na pintura, mas aquele em que Enéias a contempla, desvela um segundo nível de leitura, mais relevante para a Eneida: agora, após a queda de Tróia, quando o herói conduz sobreviventes em busca da antiga mãe, essa sucessão adquire um novo significado, passando a ser uma sucessão enquanto chefe dos troianos.

No capítulo anterior (estudo do Saque de Ílion), viu-se tal missão ser anunciada por Posídon no canto XX da Ilíada (v. 302-308). Virgílio a redimensiona na Eneida. Ao contemplar as pinturas no templo de Juno, Enéias já vivenciou os acontecimentos dos cantos II e III; no segundo, Heitor lhe aparece em sonho e lhe delegou uma missão (II, v. 268-297), e o simulacro de Creúsa o encaminha à Hespéria (II, v. 776-784); no terceiro, essa missão redefine-se para o Lácio através de um vaticínio de Apolo (v. 94-98). Para evidenciar esse diálogo com a Ilíada, Virgílio fornece um índice alusivo: os versos 97-98 do canto III evocam justamente os versos 307-308 do canto XX da Ilíada ${ }^{223}$ :

\begin{tabular}{|c|c|}
\hline 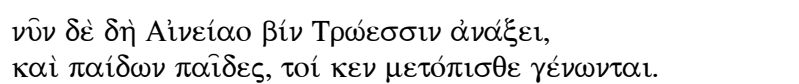 & $\begin{array}{l}\text { Hic domus Aeneae cunctis dominabitur oris } \\
\text { et nati natorum et qui nascentur ab illis. }\end{array}$ \\
\hline $\begin{array}{l}\text { mas há de o mando exercer nos troianos Enéias, o forte, } \\
\text { e quantos filhos, depois, de seus filhos a luz contemplarem. }\end{array}$ & $\begin{array}{l}\text { Lá, terras unas domará o lar de Enéias, } \\
\text { e os filhos de seus filhos, e os que deles nascerem. }\end{array}$ \\
\hline
\end{tabular}

Discutindo o reconhecimento de Enéias, A. Barchiesi (1999, p. 332) tece um comentário interessante. Reporta-se inicialmente ao capítulo XVI da Poética de Aristóteles, que trata dos tipos de reconhecimento. No terceiro tipo (1454b-1455a), por intermédio de uma lembrança, dois exemplos mostram heróis vertendo lágrimas quando a memória deles é despertada: no primeiro caso, por uma pintura; no segundo, por palavras de um citaredo (Odisseu no palácio de Alcino). Nesses casos, a reação emotiva do herói leva-o a ser (re)conhecido por outras pessoas. O caso de Enéias seria diferente: depois de sua reação

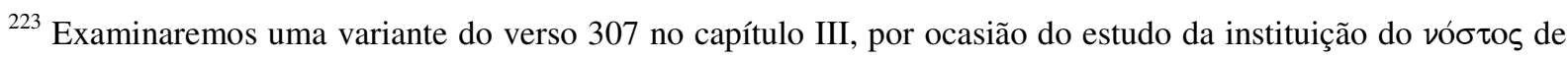
Enéias (III.3.1.2).

${ }^{224}$ Tradução de Carlos Alberto Nunes, in: HOMERO. Ilíada, 2001.
} 
emocional diante das pinturas, ele próprio se reconhece, sem consequiência imediata para outros. Segundo A. Barchiesi (p. 332), isso constitui uma inovação, pois, em exemplos anteriores conhecidos, uma reação emocional diante de uma evocação do passado teria a função narrativa de fazer com que a pessoa que reage seja reconhecida por outra.

Adicionando tal reflexão à nossa análise, delineiam-se com mais clareza funções desse reconhecimento: depois da morte de Anquises, Enéias precisa mais do que nunca se reconhecer enquanto sucessor de Heitor, enquanto líder sobre os ombros do qual recai toda a missão de conduzir os sobreviventes de Tróia que o acompanham à antiga mãe, onde deve conquistar para eles o direito de erguer uma nova cidade.

Essas considerações também incidem sobre o conteúdo do Etíope. A conexão estabelecida por Virgílio entre o episódio da morte de Heitor e o da morte de Aquiles denota ser possível e coerente a existência desses dois episódios no Etíope. Tal idéia fortalece a hipótese defendida por Kopff, segundo a qual esse épico retomaria em seu princípio a morte de Heitor - o que faria com que seu enredo se estendesse da morte e dos funerais de Heitor à morte e os funerais de Aquiles.

Concedendo-se crédito à hipótese de Kopff, toma-se, ao lado da Ilíada, o Etíope como outra provável fonte dessa imagem.

Ao fim da análise das alusões feitas pelas pinturas a poemas do ciclo troiano, vem à tona a seguinte configuração:

\begin{tabular}{|c|c|l|}
\cline { 2 - 3 } \multicolumn{1}{c|}{} & Imagens & \multicolumn{1}{|l|}{ Épicos do Ciclo Troiano referidos } \\
\hline \multirow{4}{*}{ Parte prima } & I & Ilíada \\
\cline { 2 - 3 } & II e III & Ilíada \\
\cline { 2 - 3 } & IV & Ilíada \\
\hline \multirow{3}{*}{ Parte alia } & V & \multicolumn{2}{|c|}{ Clíada } \\
\cline { 2 - 3 } & VI & Ilíada (e Etíope) \\
\cline { 2 - 3 } & VII & Etíope \\
\cline { 2 - 3 } & VIII, IX e X & \\
\hline
\end{tabular}

As pinturas aludem, pois, a três poemas do ciclo troiano, com um maior relevo para a Ilíada e o Etíope. 
Esse quadro convida à discussão um comentário de Aristóteles (Poética, 1459a-b) a respeito da noção de unidade: os poetas cíclicos teriam escolhido um só herói num só período, mas sobrecarregavam a ação de muitos episódios. Daí decorre a idéia de que Aristóteles via um herói principal em cada épico do ciclo troiano; cabe então inquirir quais seriam tais heróis. É possível supor que Aquiles desempenhasse o papel principal nos Cantos Cíprios, na Ilíada e no Etíope; isso formaria um "ciclo de Aquiles", uma unidade: esses três poemas estender-seiam de seu nascimento até sua morte. Ulisses seria o herói principal da Pequena Ilíada e da Odisséia; Neoptólemo, do Saque de Ílion. Essa hipótese geraria subdivisões no interior do ciclo troiano.

Virgílio parece ter reconhecido esse aspecto e tê-lo explorado nas pinturas no templo de Juno: as imagens da parte alia retomam e valorizam o "ciclo de Aquiles". Nessa perspectiva, contrapondo Enéias a Aquiles, a Eneida ocupar-se-ia de um suposto "ciclo de Enéias" ou, como supõe A. Barchiesi, da fama desse herói? A reconstituição que Virgílio faz do ciclo troiano pautar-se-ia também nesse critério? Respostas e outras implicações dessa estratégia virão à tona na segunda parte deste capítulo. 


\section{II.2 - Disposição das imagens}

Os estudiosos da Eneida ainda buscam um princípio convincente para explicar a disposição das imagens e justificar o emprego da expressão ex ordine no episódio das pinturas do templo de Juno. Aqui se procura outra vez esse princípio, investigando agora a ordem das imagens em função do ciclo troiano e das análises realizadas na seção anterior. Tal processo também descortinará razões para a seleção das cenas.

Todavia, antes de se empreender esta investigação, convém divisar o estado da questão através de dois pontos de vista: o daqueles que não crêem na existência de um princípio ordenador para as pinturas, dado o desconhecimento de uma interpretação convincente (apesar do ex ordine), e o daqueles que nela crêem e chegam a propor princípios ordenadores.

No princípio deste capítulo, conheceu-se a opinião de A. Barchiesi a respeito da expressão ex ordine e da disposição das imagens: o arranjo das pinturas não é cronológico, os eventos não são apresentados ex ordine.

Muito antes dele, Cartault (1926, I, p. 119-120) proferiu uma opinião semelhante:

Virgílio nos anunciou todo um conjunto abrangendo a sequiência da guerra de Tróia - Iliacas ex ordine pugnas, v. 456 -; com efeito, Dido quis representar o ciclo inteiro; ora, a enumeração não é cronologicamente ordenada nem completa; entendese, pois, que os olhos de Enéias projetam-se aqui e acolá sobre o que lhe parece mais tocante; ele não vê tudo. ${ }^{225}$

Cartault vislumbra no templo um conjunto de pinturas representando todo o ciclo troiano e, de forma curiosa, insinua que a seleção efetuada pelo olhar de Enéias seja responsável pela inexistência de uma ordem na disposição das cenas... como se a situação fosse real, como se não existisse uma intenção poética por trás da composição desse episódio.

Sete décadas mais tarde, ao tecer uma análise do episódio considerando especialmente sua elaboração enquanto ekphrasis, Putnam (1998, p. 27 e 217, nota 7) emite uma posição análoga: as pinturas não obedeceriam a uma disposição cronológica; formando uma cadeia de episódios descontínuos, convidariam o receptor a nelas procurar conexões diferentes das históricas, a "contemplá-las" uma a uma, indo e voltando, percorrendo-as em qualquer sentido; além de supostamente levar o receptor a perceber que o propósito do autor seria algo

\footnotetext{
225 "Virgile nous a annoncé tout un ensemble embrassant la suite de la guerre de Troie - Iliacas ex ordine pugnas 456 -; c'est en effet le cycle entier qu'a voulu faire représenter Didon; or, l'énumération n'est ni chronologiquement ordonnée ni complète ; la convention est donc que les yeux d'Énée se portent çà et là sur ce qui lui semble le plus poignant ; il ne voit pas tout.". Concluindo sua análise, reafirma seu pensamento: "En résumé, les tableaux qu'il fait passer sous nos yeux sont détachés les uns des autres et sans suite” (p. 122).
} 
a mais do que uma simples exposição de detalhes históricos, tal processo estaria em acordo com dois objetivos atrelados ao emprego de uma ekphrasis, um propósito atemporal e uma pausa retórica.

Essas opiniões ilustram bem posicionamentos daqueles que defendem a inexistência de um princípio ordenador para as pinturas. Outros estudiosos, no entanto, tentam descobrir esse princípio.

Debruçando-se sobre a questão, Stanley (1965, p. 274-276) postula uma organização das imagens de sorte que possam, mesmo evocando a guerra de Tróia, prefigurar, em seqüência e de forma simbólica, episódios dos cantos VII-XII da Eneida, a "Ilíada" de Virgílio. Segundo sua hipótese, as imagens II e III indicariam os combates no Lácio, com os papéis de gregos e troianos transferidos respectivamente para troianos e latinos. A morte de Reso anteciparia a imitação da "dolonéia" que Virgílio faz no canto IX. Com a morte de Troilo, Virgílio possivelmente projetaria a do filho de Mezêncio, Lauso, morto por Enéias no canto X. A imagem das troianas reportaria às preces dedicadas a Palas Atena por Amata e suas companheiras no canto XI. A morte de Heitor refletir-se-ia na de Turno no canto XII. Com Pentesiléia, duas prefigurações aconteceriam: inicialmente, o fato de a série de pinturas fechar-se com ela corresponderia à conclusão do catálogo dos latinos com Camila no canto VII - no canto XI (v. 648-649), descreve-se Camila com termos semelhantes aos empregados para Pentesiléia (I, v. 492), e a comparação entre as duas torna-se explícita (v. 659-663); em segundo lugar, essa amazona anteciparia Dido, sua descrição seria uma espécie de prólogo para o encontro de Enéias com Dido.

Infelizmente, ao relacionar as imagens a episódios específicos para justificar sua teoria, a sequiência se desfaz; e as cenas de Mêmnon e do reconhecimento de Enéias ficam ausentes da discussão.

Williams (1960, p. 148-151) discorre sobre a escolha e o arranjo das imagens de forma mais consistente - influenciado, até certo ponto, pela leitura de Cartault (1926, I, p. 117-122). De início, faz uma consideração geral: haveria uma relação entre as pinturas, e a função delas (assim como a do escudo de Enéias) não se resumiria a uma ekphrasis decorativa. Em seguida, expõe uma proposta recorrente para a disposição, em pares: I: fuga dos gregos, fuga dos troianos; II: morte de Reso, morte de Troilo; III: súplica das troianas, súplica de Príamo; IV: o exército oriental de Mêmnon, as amazonas de Pentesiléia. Sem emitir juízo sobre tal 
proposta, enfatiza o princípio condutor de sua hipótese: a seleção e o arranjo das pinturas estariam subordinados a uma relação entre elas e os motivos do poema. Williams então apresenta uma organização das pinturas divida em três seções, também alicerçada na intensidade das emoções que despertam em Enéias: uma primeira seção abrangeria cenas gerais de combates (a fuga dos gregos e a fuga dos troianos); depois, um bloco central conteria a imagem de Reso, a de Troilo, a da súplica das troianas e a da súplica de Príamo ante o cadáver de Heitor; uma última seção abraçaria a imagem do reconhecimento de Enéias, a de Mêmnon e a de Pentesiléia.

O bloco central, ao qual dispensa mais atenção, retrataria dois temas: os fata troiana, a série de oráculos e profecias associados à queda de Tróia, e a crueldade dos gregos. A imagem da morte de Reso evocaria o oráculo correspondente e mostraria como a crueldade grega impediu a salvação da cidade. A imagem da morte de Troilo ilustraria os mesmos dois temas desse bloco, em especial a crueldade de Aquiles; e o oráculo ligado a Troilo ficaria implícito após uma alusão explícita àquele ligado a Reso. Na imagem da súplica das troianas, Atena representaria a encarnação divina do destino fatídico de Tróia, com a expressão Non aequa exprimindo a crueldade da deusa - Williams levanta a hipótese de essa imagem também se relacionar com a terceira profecia da queda de Tróia: o roubo do paládio (referido no canto II, v. 166). Essas três cenas traduziriam os fados, as causas, os temas. Enfim, a imagem da súplica de Príamo ante o cadáver de Heitor espelharia a certeza última da queda de Tróia, com a intensidade emocional e os dois temas do bloco central atingindo o clímax, caracterizado pelo verso "Tum uero ingentem gemitum dat pectore ab imo" (v. 485) e pela comovente figura de Príamo.

Depois desse ápice, viriam as três pinturas finais, de menor importância emocional, as quais nos afastariam da tragédia troiana. A cena do reconhecimento de Enéias prepararia o reconhecimento do herói por Dido no verso 617 (Tune ille Aeneas). As duas imagens finais, que não provocam reação em Enéias, diminuiriam a tensão - seriam mais distantes, míticas, com uma espécie de esplendor quase irreal. Segundo Williams, a tensão emocional deveria diminuir a fim de se criar uma transição para a intensa entrada da rainha de Cartago.

Arrematando sua análise, salienta a importância de Enéias para o episódio: o herói é o filtro através do qual "vemos" as pinturas, sobre ele algumas delas exercem um forte impacto emocional, e ele próprio se encontra retratado em uma delas, e logo após o clímax. Essa 
dependência de Enéias reforçaria o elemento subjetivo presente na interpretação das pinturas, bem como seria responsável pelo diminuendo emocional nas duas cenas finais, não vinculadas diretamente ao herói.

Ainda que não desvelem um princípio organizacional convincente, alguns desses ensaios de interpretação constituem leituras possíveis do episódio, validadas por índices fornecidos pelo texto, as quais reaparecerão ao longo deste estudo.

Passa-se agora à investigação de um princípio estrutural para as pinturas pautada na relação existente entre elas e poemas do ciclo troiano.

Cabe ressaltar de início que a divisão das pinturas em duas séries (parte prima e parte alia) é essencial nesta análise. O quadro resultante do estudo empreendido na seção anterior deste capítulo mostra que a primeira série consagra-se inteiramente à Ilíada e que a segunda manifesta uma ordenação correspondente à seqüência cronológica dos poemas do ciclo troiano: os Cantos Cíprios, a Ilíada e o Etíope. Com o objetivo de discutir essa ordem, examinam-se razões para a seleção das cenas e as conseqüentes formações de sentido.

\section{II.2.1 - Parte prima}

Nessa série, as imagens I, II e III anunciam e resumem a Ilíada: a inicial evoca o proêmio e o "mote" da primeira ação do épico, a querela entre Aquiles e Agamêmnon; a segunda e a terceira evocam duas outras ações do poema, a supremacia troiana decorrente do retiro de Aquiles e a posterior supremacia grega decorrente do retorno de Aquiles. Tais imagens revelam-se didáticas, estabelecem, de forma inequívoca e ao mesmo tempo geral, o ponto de partida da estratégia delineada nesse episódio da Eneida: a Ilíada.

Sobrevém então um evento específico, a morte de Reso. Por que expor um fato específico após haver anunciado e resumido a Ilíada? E por que escolher justamente o episódio de Reso, entre tantos outros? Sabe-se que Reso faz referência a um oráculo ligado à queda de Tróia, um dos fata (que não se cumpriu); aliás, dos oráculos relacionados à queda dessa cidade, o de Reso é o único pertencente aos acontecimentos próprios da Ilíada na sucessão do ciclo troiano. Por conseguinte, após uma descrição geral dessa epopéia, a seleção desse episódio sugere um direcionamento do ponto de vista para uma esfera determinada: uma discussão a respeito da queda de Tróia valorizando suas motivações fatídicas. 


\section{II.2.2 - Parte alia}

A imagem selecionada dentre os episódios dos Cantos Cíprios, a de Troilo, põe em cena outro oráculo vinculado à queda de Tróia. Isso reforça a idéia de um direcionamento do ponto de vista para as razões fatídicas desse evento.

$\mathrm{Na}$ mesma perspectiva, a pintura de Atena indiferente às súplicas troianas, evocando a Ilíada, materializa a queda de Tróia no plano divino, a inclemência de alguns deuses em relação à sorte troiana.

E se alcança o clímax dessa linha de sentido, como Williams inferiu, com a imagem do cadáver de Heitor: a morte do grande defensor de Tróia sela a tomada da cidade. No que tange à disputa em torno de sua fonte, quer refira-se apenas à Ilíada, quer também se refira ao Etíope, importa salientar que a ordem dos poemas do ciclo troiano aludidos pelas pinturas não se desfaz: depois da Ilíada, segue o Etíope; no final das contas, ao lado do episódio das troianas indo ao templo de Atena, teríamos mais um evento da Ilíada ou um evento comum à Ilíada e ao Etíope.

As três imagens finais inspiram-se no Etíope; porém, em relação à progressão do enredo reconstituído no capítulo anterior, declaram-se invertidas: nesse épico, inicialmente Aquiles mata Pentesiléia, depois Mêmnon e enfim é morto - essa inversão acontece no nível interno, não afetando a ordem dos poemas do ciclo troiano expressa na segunda série de pinturas. Além de invertidas, não se coadunam em princípio com a linha de sentido da queda de Tróia; é possível, no entanto, entrever um enquadramento das duas últimas nessa linha: embora não descrevam a morte de Mêmnon e Pentesiléia, as pinturas aludiriam ao fato de que no Etíope os dois perdem a vida pelas mãos de Aquiles e dessa forma fracassam em sua tentativa de evitar a tomada da cidade. E o contexto fortalece essa alusão: no estudo da imagem VIII, observou-se que, à exceção de Enéias, todas as personagens guerreiras representadas na segunda série de pinturas foram vitimadas por Aquiles (Troilo, Heitor, Pentesiléia e Mêmnon). Esse dado distingue Enéias nessa série e o põe em relação com Aquiles.

Enéias e Aquiles. Emerge aqui um indício de exploração do suposto "ciclo de Aquiles" há pouco discutido.

Em decorrência dessas reflexões, as imagens selecionadas compõem um horizonte de significação voltado para a queda de Tróia, distinguindo nesse evento o papel de Aquiles, os 
fata e a intervenção divina. As três imagens iniciais mostram que a chance dos troianos residia na ausência de Aquiles dos combates (imagens I e II), depois que esse guerreiro retorna (imagem III), principia a fatídica derrota troiana. As imagens seguintes deslindam causas específicas do excídio: na de Reso e na de Troilo, os oráculos que não se cumpriram; na de Atena, a ação dos deuses; enfim, a superioridade de Aquiles, autor das mortes de Troilo, Heitor, Mêmnon e Pentesiléia.

Essas representações demonstram que Tróia não poderia ser salva. Com isso, em um primeiro plano de sentido, as pinturas justificam a queda da cidade isentando os troianos de culpa e, sobretudo, absolvendo Enéias, aquele que não sucumbiu como os demais guerreiros representados e sobre o qual pesa a angústia da "fuga". Esse sentido se conjuga plenamente com as palavras que Heitor lhe endereça em sonho (II, v. 289-292).

Destarte, a mensagem tecida pela seleção e pela composição das imagens destina-se especialmente a Enéias. O revolver de sua memória e de suas emoções aliam-se ao consolo ofertado por esse primeiro plano de sentido para lhe proporcionar uma verdadeira catarse.

Subsiste averiguar a inversão das três imagens finais, o que enseja uma discussão mais aprofundada da ordem das pinturas, desvelando novas relações entre elas e, conseqüentemente, um segundo plano de sentido.

Expôs-se um motivo para essa inversão no comentário do estudo dedicado por Williams (1960) às pinturas no templo de Juno: preparar com a imagem de Pentesiléia a entrada de Dido no templo (e no poema) e estabelecer desse modo um paralelo entre elas.

Tal explicação é inteiramente válida. Entretanto, a inversão manifesta-se antes, na cena do reconhecimento de Enéias; com isso, essa imagem, já destacada na concretização do primeiro plano de sentido, adquire relevos ainda maiores. Em conseqüência, a busca de razões para a inversão deve levar em consideração o ponto em que essa estratégia se pronuncia.

Por esse prisma, um motivo para a inversão patenteou-se na primeira parte deste capítulo, no estudo da pintura do cadáver de Heitor: posicionar a cena do reconhecimento de Enéias logo após à da morte de Heitor para indicar a idéia de sucessão. Com efeito, se as três imagens do Etíope aparecessem em sua ordem normal, a do reconhecimento seria a última, distante, pois, da imagem da morte de Heitor; dessa maneira, o índice alusivo da sucessão esvair-se-ia. 
Outros motivos vêm à tona quando se investiga a missão de Enéias anunciada no canto XX da Ilíada (v. 302-308), redimensionada por Heitor (II, v. 268-297) e confirmada por Apolo na Eneida (III, v. 94-98): a sucessão de Heitor enquanto chefe dos troianos. Essa perspectiva encaminha a discussão para dois temas que deveriam ser tratados no ciclo troiano e que se deixam entrever na Ilíada: a sorte distinta reservada aos dois ramos de Dárdano, o de Ilo e o de Assáraco, e uma eventual querela entre eles. Enéias e Heitor representam os grandes guerreiros desses ramos: Heitor, o de Ilo; Enéias, o de Assáraco.

Examinando a relação entre os dois heróis, Smith (1981, p. 47-48) perscruta um paralelo existente entre o episódio da salvação de Enéias e o da morte de Heitor na Ilíada: no canto XX, ao enfrentar Aquiles, Enéias é salvo por uma divindade; no canto XXII, ao enfrentar Aquiles, Heitor é abandonado por Atena. Assim, a salvação de Enéias seria uma preparação para a morte de Heitor. Smith (p. 50) considera que a exposição da genealogia de Dárdano no canto XX (v. 213-241) teria por objetivo prenunciar a continuidade dessa estirpe através de Enéias:

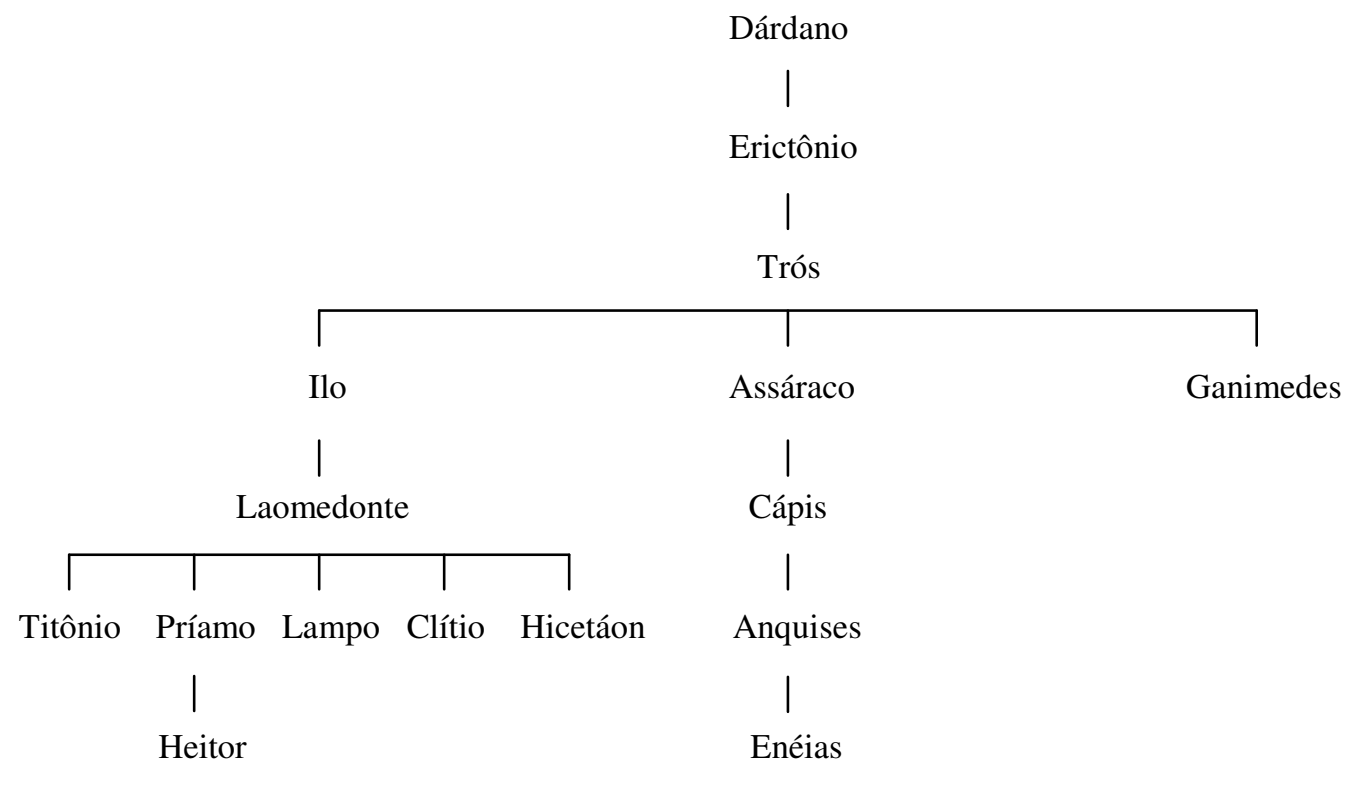

É significativo o fato de que essa genealogia desfiada por Enéias para Aquiles conclua-se com ele de um lado e Heitor do outro, no mesmo nível, e não faça menção aos demais filhos de Príamo. Isso põe em foco a sucessão no governo de Tróia: Heitor seria naturalmente o próximo chefe dos troianos, mas tal encargo acaba recaindo sobre Enéias.

A fim de se extrair mais sentidos desse paralelo, analisa-se inicialmente a participação de Apolo no canto XX e a construção dos referidos episódios. 
Enquanto Aquiles, desejoso de vingança, busca Heitor no campo de batalha (v. 75-78), Apolo, disfarçado de Licáon (um membro do ramo de Ilo), vai até Enéias e o induz a enfrentar o pelida (v. 79-111), desviando para este o combate que Aquiles deseja travar com Heitor e a conseqüente morte.

E a construção dos episódios ratifica esse paralelo:

\begin{tabular}{|l|l|}
\hline \multicolumn{1}{|c|}{ Canto XX } & \multicolumn{1}{c|}{ Canto XXII } \\
\hline $\begin{array}{l}\text { No Olimpo, Posídon pede a salvação de Enéias } \\
\text { (v. 291-308) }\end{array}$ & $\begin{array}{l}\text { No Olimpo, Zeus pede a salvação de Heitor } \\
\text { (v. 167-176) }\end{array}$ \\
\hline $\begin{array}{l}\text { Posídon recebe de Hera a autorização para livrar } \\
\text { Enéias (v. 309-317) }\end{array}$ & Atena rejeita a proposição de Zeus (v. 177-181) \\
\hline Posídon salva Enéias (v. 318-343) & $\begin{array}{l}\text { Apolo é obrigado a desamparar Heitor após a } \\
\text { sentença da balança de Zeus (v. 208-213), então } \\
\text { Atena ajuda Aquiles a liquidar Heitor (214-305) }\end{array}$ \\
\hline
\end{tabular}

Enéias salvo, Apolo, após “o fracasso de seu plano", retorna à cena para aconselhar Heitor a não combater Aquiles (v. 375-380). E, quando Aquiles e Heitor enfim se encontram e duelam, o deus arrebata o filho de Príamo (v. 443-454).

A genealogia, o papel de Apolo e a confecção similar dos episódios tornam muito mais saliente na Ilíada a relação entre a salvação de Enéias e a morte de Heitor, decorrência e, ao mesmo tempo, indício da sorte distinta dos dois ramos. No capítulo anterior, viu-se que o Saque de Ílion também deveria abordar a querela entre os dois ramos da família de Dárdano. Tais constatações ampliam os contornos desses temas no interior do ciclo troiano.

Virgílio teria explorado na Eneida a sorte distinta desses ramos?

Uma resposta afirmativa evidencia-se com a alusão feita pelos versos 97 e 98 do canto III à profecia de Posídon na Ilíada (XX, v. 302-308), passagem que proclama, com todas as letras, o fim do ramo de Ilo e o destino de Enéias como chefe dos troianos. Sob esse enfoque e à luz das noções de sucessão discutidas no estudo da imagem VIII, o episódio em que Heitor delega a missão a Enéias configura-se como uma verdadeira cerimônia de transmissão de poder: retomando a genealogia exposta na Ilíada, encontram-se em cena os dois últimos apresentados; então, o futuro soberano de Tróia pelo ramo de Ilo passa a Enéias a guarda da essência sagrada da cidade (Sacra suosque tibi commendat Troia penatis, v. 293). Esse episódio concretiza de forma alegórica (e sublime) o anúncio de Posídon, a sorte distinta da 
descendência de Dárdano: o ramo moribundo, representado pelo falecido Heitor, cede o poder ao ramo destinado a sobreviver e reinar.

Quanto à eventual querela entre os ramos, a Eneida a retoma de forma mais sutil. A linhagem de Assáraco é exaltada e reconhecida como origem dos romanos. Ao anunciar o destino grandioso dos descendentes de Enéias, Júpiter a eles se refere com a expressão domus Assaraci (I, v. 284), limitando a glória à estirpe de Dárdano proveniente desse ramo. No canto VI, a concepção de que os romanos dão continuidade à gens Assaraci torna-se patente: Romulus, Assaraci quem sanguinis Ilia mater / educet (v. 778-779). E Ascânio, no canto IX (v. 257-260), faz um juramento a Niso invocando como penhor a honra do Assaraci Lar ${ }^{226}$. Por outro lado, o ramo de Ilo é vituperado nitidamente em duas ocasiões, nas quais a perfídia de Laomedonte ${ }^{227}$ é relembrada. No canto III, depois que os troianos devoram bois das Harpias, Celeno os acusa nomeando-os Laomedontiadae. No canto IV (v. 541-542), em meio às invectivas lançadas por Dido contra o "ingrato" Enéias, eclode a falta de honra de Laomedonte, por ela estendida aos descendentes deste: nescis heu, perdita, necdum /

\section{Laomedonteae sentis periuria gentis?.}

Nesse cenário, trazendo à baila o ressentimento demonstrado por Enéias na Ilíada em relação a Príamo, percebe-se que o mesmo não ocorre na Eneida; aliás, a reação dele diante das pinturas com Príamo revelam respeito pelo monarca - apenas contra Páris uma reprovação da parte de Enéias transparece em meio às palavras com as quais Vênus tenta demover o filho do ímpeto de vingar-se de Helena (II, v. 594-620): culpatus Paris ( v. 602).

Retornando ao ponto de partida, todo esse diálogo entre a Eneida e a Ilíada fortalece a idéia de que um dos motivos principais da inversão das imagens finais reside no delinear da missão de Enéias em função do tema da sorte distinta dos ramos descendentes de Dárdano.

Além desse resultado, essas considerações descortinam um liame entre essa temática e a imagem de Atena indiferente às troianas suplicantes. A participação dessa divindade nos episódios da morte de Heitor na Ilíada amplia a significação da imagem VI: a representação da recusa da deusa à suplica das troianas evoca sua recusa ao pedido de Zeus para salvar Heitor no canto XXII da Ilíada; por conseguinte, evoca-se o papel dela na morte de Heitor. Esse campo de significação mais amplo permite discernir razões para a escolha dessa imagem

\footnotetext{
${ }^{226}$ Ver ainda o testemunho de Apolo no canto IX (v. 643: gente Assaraci).

${ }^{227}$ Cf. HOMERO, Ilíada, XXI, v. 441-458 e APOLODORO, Biblioteca, II, 5, 9.
} 
e justifica seu posicionamento antes da cena da morte de Heitor. Assim, as imagens VI, VII e VIII revelam-se lógica e ordenadamente atreladas.

Para que relações entre a pintura do reconhecimento de Enéias e a da morte de Heitor fossem evidenciadas, fez-se ouvir um diálogo entre a Eneida e a Ilíada. Desse diálogo ainda participa o Etíope, uma vez que os elos entre a sobrevivência de Enéias e a morte de Heitor também se manifestam no episódio da morte de Aquiles. O esquema seguinte ajuda a compreender tal questão:

\begin{tabular}{|l|c|c|}
\hline \multicolumn{1}{|c|}{ Ilíada, XX } & Ilíada, XXII (e Etíope) & Etíope \\
\hline $\begin{array}{c}\text { Enéias salvo de Aquiles } \\
\text { preparação da morte de Heitor) }\end{array}$ & Aquiles mata Heitor & $\begin{array}{c}\text { Morte de Aquiles } \\
\text { (Enéias participa da luta pelo corpo do } \\
\text { herói) }\end{array}$ \\
\hline $\begin{array}{l}\text { Anúncio do destino de Enéias como } \\
\text { sucessor do ramo governante dos } \\
\text { troianos (v. 302-308) }\end{array}$ & $\begin{array}{c}\text { Morte de Heitor: } \\
\text { condição para Enéias } \\
\text { emergir como chefe }\end{array}$ & $\begin{array}{c}\text { Morte de Aquiles: } \\
\text { Anúncio da condição para a glória } \\
\text { guerreira de Enéias (v. 337-339) }\end{array}$ \\
\hline
\end{tabular}

Esse quadro reclama um estudo realizado por Michael J. Anderson (1997, p. 69-71) acerca da temática da queda de Tróia na poesia grega mais antiga e na arte, segundo o qual os livros finais da Ilíada elaborariam um contraponto entre Enéias, o sobrevivente, e os dois guerreiros destinados a morrer, Aquiles e Heitor. De acordo com sua análise, além do paralelo entre Enéias e Heitor, também existiria um entre Enéias e Aquiles: ambos são desonrados por seus chefes, e a reação dos dois é semelhante (este se retira dos combates, aquele hesita em combater); e, ao expor a Aquiles sua genealogia, Enéias se afirma equivalente ao pelida.

Constata-se que o canto XX da Ilíada prefigura funções da morte de Heitor no interior do próprio poema homérico e da morte de Aquiles no Etíope ${ }^{228}$ em relação a Enéias; em conseqüência, determinados sentidos pertinentes a Enéias estocados nesses épicos dependem do canto XX para uma concretização mais ampla.

No que tange à Eneida, à luz desse quadro, as imagens VII e VIII associam-se em função de Enéias: a do cadáver de Heitor expõe a condição para a concretização do primeiro

\footnotetext{
${ }^{228}$ Esses entrelaçamentos de sentidos reforçam ainda mais a hipótese defendida por Kopff: o Etíope relatava de algum modo a morte de Heitor. E isso suscita a seguinte questão: o Etíope também exploraria o tema da sorte distinta dos ramos descendentes de Dárdano e o relevante papel de Enéias nessa contextura?
} 
anúncio de Posídon; a da luta pelo corpo de Aquiles, a condição para a efetivação do segundo anúncio.

Essa subjacência de Enéias pode estender-se ainda até a imagem da morte de Tróilo.

Anderson (1997, p. 62-74) examina a salvação de Enéias durante a queda de Tróia e a coteja com três outros momentos em que o herói se esquiva da morte:

- no encontro com Aquiles no monte Ida, quando este rouba seu gado (episódio dos Cantos Cíprios, evocado na Ilíada (XX, v. 89-93 e v. 187-194);

- no duelo com Diomedes, salvo por Afrodite e Apolo (Ilíada, V, v. 311-317 e v. 431-469);

- no combate contra Aquiles, salvo por Posídon (Ilíada, XX, v. 318-343).

A partir desses eventos, Anderson conclui que a sobrevivência (em geral decorrente de intervenções divinas) seria a característica particular de Enéias (tal qual a astúcia de Odisseu) - esse aspecto projeta uma nova luz sobre o verso 463 do canto I (Solue metus; feret haec aliquam tibi fama salutem, apreciado em II.1.1); a expressão aliquam salutem faria menção a essa particularidade de Enéias e poderia ser interpretada como "outra salvação" (mais uma), nesse caso proporcionada pela fama. Para Anderson, os autores dos Cantos Cíprios, da Ilíada e do Saque de Ílion teriam reconhecido e trabalhado esse traço distintivo. Na exploração dessa característica nos épicos do ciclo troiano, construções semelhantes e paralelos formar-se-iam, e Anderson (p. 71-72) consegue desvelar a seguinte equivalência: assim como na Ilíada o encontro de Aquiles e Enéias prepara o de Aquiles e Heitor, nos Cantos Cíprios o encontro de Aquiles e Enéias no monte Ida prefiguraria o de Aquiles e Troilo; Enéias salva-se nas duas ocasiões, enquanto os filhos de Príamo são mortos.

Essa análise sugere que os Cantos Cíprios também deveriam explorar o tema dos ramos de Ilo e Assáraco. Além disso, fornece uma grande contribuição a este trabalho: demonstra que a subjacência de Enéias estende-se até a imagem da morte de Troilo e amplia a oposição entre Aquiles e Enéias.

Ao fim desse segundo curso investigativo em busca de razões para a inversão das três últimas imagens, incitado pelo exame do tema da sorte distinta reservada aos ramos descendentes de Dárdano, as pinturas V, VI, VII e VIII dão-se as mãos e delineiam um segundo plano de sentido, concebido em função de Enéias, mais precisamente em função do tratamento concedido a esse herói no ciclo troiano até a concretização de sua glória enquanto guerreiro: ao selecionar e ordenar essas imagens, Virgílio reuniu episódios que refletem a 
característica particular, a glória guerreira e a missão da personagem principal de seu épico. Para Enéias, essas imagens compõem um painel retrospectivo de sua história na saga troiana, um apelo mnemônico para que se redefina; nessa perspectiva, a cena do reconhecimento simboliza uma tomada de consciência de mensagens que lhe são destinadas. Para a Eneida, essa recapitulação da lenda de Enéias no ciclo troiano manifesta intenções poéticas: dar continuidade a esse ciclo concretizando e redimensionando o primeiro anúncio de Posídon no canto XX da Ilíada, a missão de Enéias enquanto chefe dos troianos.

O descortinar desse segundo plano de significação justifica o posicionamento desse episódio no canto I: as pinturas constituem um verdadeiro ponto de contato entre os épicos anteriores do ciclo troiano e o épico de Virgílio, marcando o início a inserção da Eneida nesse ciclo.

Nessa parte, o estudo da disposição das pinturas no templo de Juno revelou a existência de dois planos de sentido conjugados no horizonte de significação do episódio. No primeiro plano, enfocando o papel de Aquiles, os fata e a intervenção divina, as imagens discutem a queda de Tróia, absolvendo os troianos de culpa e oferecendo um consolo a Enéias. No segundo, proporcionado pelo exame da inversão das três cenas finais, as imagens da segunda série associam-se em função de Enéias, propiciando ao herói uma retrospecção de sua saga e o reconhecimento de si e de sua missão e propiciando à Eneida uma declaração de suas intenções poéticas.

No tocante à disposição em si, a expressão ex ordine funciona em relação aos poemas, não em relação aos episódios representados, e leva em consideração a divisão das pinturas em duas séries. Na primeira série, há apenas a Ilíada. Na segunda, o ex ordine se faz sentir: os poemas seguem a seqüência cronológica do ciclo troiano: Cantos Cíprios, Ilíada e Etíope. Para os episódios representados, a seleção e a ordenação das imagens seguem princípios revelados nos dois planos de sentido formadores do horizonte de significação do episódio.

Importa ainda discutir o destaque dado à Ilíada na primeira série. Ao longo dessa investigação, verificou-se o valor que a Eneida acorda a esse poema homérico, sobretudo ao canto XX, um centro de onde emanam as intenções poéticas da Eneida e grande parte dos sentidos concretizados nessa leitura. Além disso, o fato de Virgílio resgatar o ciclo troiano para nele inserir seu épico traz à luz o papel da Ilíada na constituição desse ciclo: dos poemas 
conhecidos que abordam a saga troiana, a Ilíada foi o primeiro a ser composto, os demais, que mais tarde seriam reunidos em um ciclo, foram elaborados levando em conta esse épico primeiro, preenchendo lacunas por ele deixadas e concretizando informações por ele fornecidas (recordação de eventos anteriores e anúncios de posteriores). Ao consagrar a primeira série inteira à Ilíada, Virgílio reconhece e evidencia a importância desse épico para o ciclo troiano e para a Eneida; parece querer explorar o fato de esse épico ser, na prática, o fundador desse ciclo, a referência para a composição dos demais, inclusive da Eneida. Em poucas palavras, o poeta latino mimetiza a constituição do próprio ciclo troiano em função da Ilíada. 


\section{II.3 - A arte da memória no episódio das pinturas do templo de Juno}

Est enim finitimus oratori poeta (De Oratore, I, 70)

$\mathrm{Na}$ introdução desta tese, fez-se a seguinte pergunta: “Ao vermos Enéias diante das pinturas do templo de Juno, estaríamos também vendo "um orador" diante de representações e da ordem de assuntos constituintes de um discurso?". A partir dos índices fornecidos pelo texto acerca dessa questão, forjou-se o pressuposto de que, nesse episódio, Virgílio empregaria e ao mesmo tempo poria em cena a teoria retórica da arte da memória. Demonstra-se agora esse pressuposto.

Os estudos realizados nas seções I e II deste capítulo revelaram que as pinturas relembram em especial epopéias do ciclo troiano e que sua disposição segue um princípio ordenador: duas séries; a primeira evoca a Ilíada; a segunda, os Cantos Cíprios, a Ilíada e o Etíope. Com isso, o episódio configura-se da seguinte forma: Enéias encontra-se em uma sala na(s) parede(s) da qual há imagens dispostas ex ordine, as quais despertam memória daquele que as contempla, a recordação de acontecimentos a serem explorados na Eneida.

Essa configuração concretiza o sentido prefigurado no verso 464 e remete o leitor à teoria da arte da memória. Desenvolvidos no mundo grego ${ }^{229}$, os procedimentos dessa técnica foram preservados por tratados latinos: sua primeira descrição conhecida surge na Rhetorica ad Herennium (III, 28-40); pouco depois Cícero sobre ela discorre no De Oratore (II, 350360); mais tarde, Quintiliano a retoma na Institutio Oratoria (XI, 2, 1-51).

A arte da memória (ou mnemotécnica) constitui um procedimento criado para facilitar a memorização ordenada dos conteúdos de um discurso. Para compreendê-la, recorre-se essencialmente à Rhetorica ad Herennium, por se tratar da abordagem mais elaborada e porque sua exposição concebe um verdadeiro método de narrativa pictórica, profícuo àqueles que desejem empregar uma linguagem imagética.

Segundo estudos de Guy Achard (1989), esse tratado teria sido escrito entre meados de 86 e o começo de 82 a. $\mathrm{C}^{230}$. Apesar de ser a mais antiga obra da retórica latina de que dispomos, não é a primeira: no De Oratore (I, 94), há uma alusão a um pequeno livro

\footnotetext{
${ }^{229}$ Embora a técnica exista provavelmente desde o século V a. C., o elaborado aspecto com que chegou ao mundo romano é fruto do período helenístico. Small (1996, p. 83 e 95) pleiteia que a inclusão da memoria na retórica tenha ocorrido somente no período helenístico, talvez no final século II a. C., favorecida pela geração anterior à do autor da Rhetorica ad Herennium.

${ }^{230}$ Para Small (1997, p. 98), esse tratado foi escrito entre 88 e 85 a. C.
} 
(libellum) que teria sido escrito por M. Antônio (143-87 a. C.) e que, contra a vontade do autor, teria circulado entre os romanos; na Institutio Oratoria (III, 1, 19), Quintiliano, além de confirmar a alusão do De Oratore, indica M. Catão (234-149 a. C.) como o primeiro autor romano de uma obra sobre retórica. Infelizmente, nesse trecho do livro terceiro, que faz um inventário de autores latinos de obras sobre retórica, Quintiliano nada informa acerca da autoria da Rethorica ad Herennium... e em nenhuma outra parte de seus escritos. A ausência de menção não é exclusividade dele, não se conhecem referências a esse tratado até o começo do século V d. C., quando enfim passa a ser citado, atribuído a Cícero: de acordo com Achard (p XIV), as primeiras referências ocorrem em obras de São Jerônimo (Apologia aduersus libros Rufini, de 402, e Commentarii in Abdiam, de 403).

Esse silêncio sobre a obra põe em dúvida sua circulação na época de Virgílio; não podemos, portanto, afirmar que esse poeta a tenha consultado. Apesar disso, esse manual não perde seu interesse: lançamos mão dele como um valioso testemunho de teorias e práticas retóricas que circulavam no universo romano no início do século I a. C. e que deveriam fazer parte do conhecimento de Virgílio.

Atribuída ao poeta Simônides de Ceos (c.556-468 a. C.)231, a arte da memória consiste em uma técnica de memorização que trabalha com lugares e imagens, assim definidos na Rethorica ad Herennium (III, 29)232:

Nunc de artificiosa memoria loquemur.

Constat igitur artificiosa memoria locis et imaginibus. Locos appellamus eos qui breuiter, perfecte, insignite aut natura aut manu sunt absoluti, ut eos facile naturali memoria conprehendere et amplecti queamus: ut aedes, intercolumnium, angulum, fornicem et alia, quae his similia sunt. Imagines sunt formae quaedam et notae et simulacra eius rei quam meminisse uolumus: quod genus equi, leonis, aquilae memoriam si uolemus habere, imagines eorum in locis certis conlocare nos oportebit.

Falaremos agora a respeito da memória artificial.

Constitui-se de lugares e imagens. Denominamos lugares aqueles que, de maneira exígua, completa, distinta pela natureza ou pela mão do homem, são absolutos, de tal forma que possamos facilmente percebê-los e abraçá-los com a memória natural, como uma sala, um entrecolunas, um recanto, uma abóbada e outros semelhantes a esses. Imagens são certas formas, tanto as identificações quanto as representações daquilo que desejamos lembrar, por exemplo: se quisermos evocar a memória de um cavalo, de um leão, de uma águia, será necessário dispor as imagens deles em lugares determinados.

\footnotetext{
${ }^{231}$ Cícero (De Oratore, II, 351-354) e Quintiliano (Institutio Oratoria, XI, 2, 11-16) contam a história da descoberta dessa técnica.

${ }^{232}$ Para o texto latino, servimo-nos da edição de Achard (1989) para a editora "Les Belles Lettres".
} 
Após defini-los, o tratado

ensina a empregar os

lugares e as imagens, aproximando o método de composição e emissão de um texto elaborado com a mnemotécnica do método de escrita e leitura de um texto elaborado com a linguagem verbal:

Quemadmodum igitur qui litteras sciunt possunt id quod dictatum est eis scribere et recitare quod scripserunt, item qui nemonica didicerunt possunt quod audierunt in locis conlocare et ex his memoriter pronuntiare. Nam loci cerae aut cartae simillimi sunt, imagines litteris, dispositio et conlocatio imaginum scripturae, pronuntiatio lectioni ${ }^{233}$.

Assim como aqueles que conhecem as letras podem, pois, escrever o que lhes é ditado e ler em voz alta o que escreveram, assim também aqueles que aprenderam a mnemotécnica podem colocar o que ouviram em lugares e a partir destes pronunciá-lo de memória. De fato os lugares são semelhantes às tábuas de cera ou às folhas de papiro; as imagens, às letras; a disposição e a localização conjunta $^{234}$ das imagens, à escrita; o ato de pronunciar o discurso, à leitura.

Essa teoria aplica-se tanto à memória de assuntos (rerum memoria) quanto à de palavras (uerborum memoria). Sua aplicação à memória de assuntos faculta a memorização de um texto da seguinte forma: divide-se coerentemente o texto em partes; compõe-se uma imagem para representar o conteúdo de cada parte; depositam-se as imagens em lugares com uma ordem previamente estabelecida (no lugar 1, a imagem corresponde ao início do texto; no lugar 2, a imagem correspondente à segunda parte do texto... e assim por diante). Desse modo, é possível relembrar todo o conteúdo do texto e na seqüência desejada.

Os lugares podem ser imaginários ou tomados da realidade ${ }^{235}$. Se precisarmos de muitos lugares, cada múltiplo de cinco convém ser identificado (III, 31). Ao longo da afirmação de que os lugares devem ser ordenados, emerge a mesma expressão usada na Eneida: Item putamos oportere ex ordine hos locos habere (III, 30).

Depois de discorrer sobre os lugares (III, 30-32), o autor da Rethorica ad Herennium trata das imagens (III, 33-37). Nesse trecho, um exemplo de composição de uma imagem para

\footnotetext{
${ }^{233}$ A mesma comparação aparece no tratado de Cícero (De Or., II, 354: sic fore, ut ordinem rerum locorum ordo conseruaret, res autem ipsas rerum effigies notaret atque ut locis pro cera, simulacris pro litteris uteremur.) e deste migra para o de Quintiliano (Inst. Or., XI, 2, 21: Imagines uoco ea quae ediscenda sunt notamus, ut, quo modo Cicero dicit, locis pro cera, simulacris pro litteris utamur.). Coincidências como essas corroboram a idéias de que essas teorias circulavam entre os romanos.

${ }^{234}$ Em latim: dispositio et conlocatio. Traduzimos conlocatio (< cum e loco) por localização conjunta na ânsia de preservar o sentido do prefixo cum, importante para o contexto. Acreditamos que a idéia veiculada por essa expressão aproxime-se de uma sintaxe de imagens, ou seja, de uma localização interdependente.

${ }^{235}$ Segundo J. Penny Small (1997, p. 95), a adoção de lugares reais para a mnemotécnica pode constituir uma inovação dos romanos.
} 
representar um determinado conteúdo arremata a teoria da rerum memoria e fomenta nossa discussão (III, 33-34):

Rei totius memoriam saepe una nota et imagine simplici conprehendimus, hoc modo, ut si accusator dixerit ab reo hominem ueneno necatum et hereditatis causa factum arguerit et eius rei multos dixerit testes et conscios esse; si hoc primum, ut ad defendendum nobis expeditum sit, meminisse uolemus, in primo loco rei totius imaginem conformabimus: aegrotum in lecto cubantem faciemus ipsum illum de quo agetur, si formam eius detinebimus; si eum non agnouerimus, at aliquem aegrotum non de minimo loco sumemus, ut cito in mentem uenire possit, et reum ad lectum eius adstituemus, dextera poculum, sinistra tabulas, medico testiculos arietinos tenentem. Hoc modo et testium et hereditatis et ueneno necati memoriam habere poterimus. 34. Item deinceps cetera crimina ex ordine in locis ponemus; et, quotienscumque rem meminisse uolemus, si formarum dispositione et imaginum diligenti notatione utemur, facile ea quae uolemus memoria consequemur.

Apreendemos muitas vezes a memória de um caso inteiro com uma só identificação e uma única imagem, como segue. Suponhamos que um acusador tenha afirmado que um homem fora assassinado por um réu com veneno, tenha alegado crime por motivo de herança e dito haver muitas testemunhas e pessoas cientes do fato. Se inicialmente desejamos lembrar esse episódio, a fim de que nos seja fácil defendê-lo, comporemos no primeiro lugar uma imagem de todo o caso: doente, deitado em um leito, faremos aquele a respeito do qual se debate, caso saibamos a aparência dele; se não o tivermos conhecido, tomemos para o lugar outro doente, não de classe inferior, para que aquele possa vir depressa à mente; e junto ao leito dele postaremos o réu segurando com a mão direita um copo, com a esquerda tábuas e com o dedo anular testículos de carneiro. Desse modo, poderemos reter a memória das testemunhas, da herança e do morto por veneno. 34. Em seguida, da mesma maneira poremos nos lugares, em ordem, as demais acusações. E, cada vez que quisermos lembrar um caso, se utilizarmos a disposição das formas e uma cuidadosa caracterização das imagens, facilmente acompanharemos com a memória o que desejarmos.

Com esse exemplo de transformação de um texto verbal em um pictórico, a Rhetorica ad Herennium põe à disposição de seus receptores um método de composição de uma narrativa imagética, de uso simbólico da imagem, bem como uma maneira de "ler" esse gênero de narrativa. Além de retores, muitos poetas se serviram desses ensinamentos... entre eles Virgílio.

O confronto dessa teoria com a leitura da Eneida até aqui efetuada demonstra a presença da arte da memória no episódio das pinturas do templo de Juno: no interior de todo um contexto ligado à memória (discutido na introdução da tese e na interpretação do verso 464), as imagens encontram-se dispostas segundo uma ordem (ex ordine, como prega a Rhetorica ad Herennium) e estocam conteúdos fundamentais para as intenções da Eneida. Outro elemento estrutural do episódio coincidente com essa teoria retórica consiste na 
identificação do quinto lugar: a expressão Parte alia, indicativo da separação das duas séries de pinturas, abre justamente na quinta imagem - e não haveria a necessidade de identificar o décimo lugar por ser o último.

Ademais, a composição das cenas segue as diretrizes da arte da memória. Cícero (De Oratore, II, 358) resume bem as características requisitadas para as imagens na mnemotécnica ao recomendá-las em ação (agentes), vivas (acres), notáveis (insignitae), capazes de se manifestar rapidamente e de atingir o espírito com vigor.

E o autor da Rhetorica ad Herennium (III, 36) ensina ainda que as imagens devam ser inusitadas (nouitate commoueri); para fugir do comum, podem ser revestidas de uma beleza especial ou de uma torpeza única (III, 37).

Com efeito, as imagens do templo de Juno são agentes, vivas, notáveis e percutem fortemente o espírito de Enéias ${ }^{236}$. Outro aspecto relevante da mnemotécnica, em particular da teoria exposta na Rhetorica ad Herennium, transparece na expressão noua res (I, v. 450), pertencente aos versos que introduzem as pinturas: anuncia-se o mural como algo inusitado, impressionante.

Um elemento cultural também pode ser convocado como testemunha a favor do uso da mnemotécnica nesse episódio da Eneida. Estudando o lugar da memória nas pinturas parietais romanas, Bettina Bergmann (1994, p. 226) acredita que, após o desenvolvimento da decoração de paredes com pinturas, a mnemotécnica passou a influenciar o programa pictórico dos romanos. Nessa mesma linha de raciocínio, Catherine Baroin (1998, p. 177-191) atesta que a recorrência à domus como um continente de lugares na teoria da arte da memória dos tratadistas latinos aqui referidos reflete uma circunstância real: para os romanos, a domus era de fato um lugar de memória, em cuja construção a mnemotécnica tomava parte ${ }^{237}$.

Esse dado cultural franqueia uma instigante perspectiva de pesquisa: analisar esse episódio da Eneida em função do contexto da pintura romana e das manifestações desta sob a influência da arte da memória ${ }^{238}$. Seria uma nova tese... Para as pretensões desta investigação,

\footnotetext{
${ }^{236}$ No que tange a uma análise da composição das imagens, remetemos ao estudo de Putnam (1998, p. 23-54).

${ }^{237}$ Para Baroin (1998, p. 180), o destaque concedido por Quintiliano (Institutio Oratoria, XI, 2, 18-20) à domus atesta bem essa questão.

${ }^{238}$ Os trabalhos de Bergmann (1994) e Baroin (1998) abririam portas para essa pesquisa, bem como o magnífico estudo de Rouveret (1989), o qual inclusive analisa a elaboração de imagens proposta pela mnemotécnica (Cap. VI - “Artificiosa Memoria: l'invention des images”, p. 303-379).
} 
no entanto, é suficiente saber que, na época de Virgílio, a composição de pinturas parietais beneficiava-se da metodologia da arte da memória.

Em síntese, no episódio das pinturas do templo de Juno, a evocação de poemas do ciclo troiano ex ordine denuncia o emprego de procedimentos da teoria da arte da memória. $\mathrm{E}$ a memória épica assim reeditada funciona em especial na reelaboração da lenda (ou da fama) de Enéias nesse ciclo perpetrada pela Eneida. E é exatamente esse herói quem protagoniza a encenação dessa teoria: vemos o troiano, tal qual um orador repassando os conteúdos de um discurso representados por imagens, reacender sua memória da guerra de Tróia. 


\section{Conclusão do capítulo}

As investigações realizadas ao longo deste capítulo comprovaram três dos quatro pressupostos desta tese: as pinturas do templo de Juno evocam epopéias do ciclo troiano e com elas tecem uma memória épica na qual a Eneida se insere; nessa evocação de fato reside o princípio ordenador das imagens, prefigurado pela expressão ex ordine; enfim, nesse episódio, Virgílio não apenas se serve de procedimentos da teoria retórica da arte da memória mas ainda a põe em cena.

Para concluir, uma observação sobre o processo criador de Virgílio e o dos autores das epopéias perdidas do ciclo troiano.

Todas as inter-relações de episódios e as ressonâncias temáticas aqui desveladas evidenciam uma organicidade do ciclo troiano: ao compor um novo épico, os poetas examinavam com cuidados o conteúdo dos poemas já existentes nessa saga; dessa forma, concretizavam recordações, anúncios e prefigurações feitos nos épicos anteriores e compartilhavam temas e características de personagens, ora para reproduzi-los, ora para redimensioná-los. O estado do ciclo troiano permite apenas vislumbrar todos os fios que deveriam entrelaçar seus poemas.

Consciente desse processo criador e pretendendo inserir sua epopéia nesse ciclo, Virgílio explora temáticas, interdependências de episódios e anúncios praticados nos épicos anteriores. Em outros termos, além reeditar uma memória do ciclo troiano, a Eneida fornece índices alusivos que apelam à "memória épica" de seus receptores. Por conseguinte, um receptor da Eneida familiarizado com os poemas ciclo troiano deveria identificar com mais facilidade tais índices alusivos e concretizar mais sentidos por eles suscitados...

Sentidos como a continuação, nos seis cantos iniciais da Eneida, da seqüência de poemas estabelecida na segunda série das pinturas do templo de Juno - assunto do próximo capítulo. 
capítulo terceiro

\section{A arquitetura dos seis cantos iniciais da Eneida e o ciclo troiano}

Após percorrer as pinturas do templo de Juno observando o processo alusivo, a disposição e o emprego da arte da memória, sempre do ponto de vista dos elos estabelecidos entre elas e poemas do ciclo troiano, investiga-se neste capítulo o desdobramento desse episódio na arquitetura dos seis cantos iniciais da Eneida.

Antes de se atacar essa empresa, uma explicação terminológica. Ao longo das análises, empregam-se as expressões modelo estrutural e modelo episódico: a primeira aplica-se quando a influência que uma obra exerce sobre outra atinge a arquitetura, seja de uma parte, seja de um todo; a segunda, quando essa influência atinge um ou mais episódios sem, no entanto, afetar a arquitetura.

A arquitetura da epopéia de Virgílio ocupa o centro de muitas pesquisas, sobretudo depois da repercussão da tese de Paul Maury (1944) quanto à organização das Bucólicas. Nesse domínio, salientam-se duas abordagens: uma externa, que procura reconhecer na estrutura da Eneida a influência de outros poemas, notadamente os homéricos; uma interna, a qual coteja o conteúdo, a composição e até mesmo a disposição emocional dos cantos em busca de relações tangíveis.

No tocante à primeira abordagem, a lição mais difundida concebe a Eneida estruturada em duas metades em função dos poemas homéricos: a primeira modelada na Odisséia, a segunda na Ilíada. Tal lição existe desde a Antigüidade, Macróbio (c. 380-440) já a cita como algo repetido às crianças (Saturnalia, V, 2, 6: Sed et haec et talia pueris decantata praetereo. Iam uero Aeneis ipsa nonne ab Homero sibi mutuata est errorem primum ex Odyssea, deinde ex Iliade pugnas? $)^{239}$.

Contestando essa visão tradicional, faz-se ouvir no século passado a hipótese de uma predominância da Odisséia como modelo estrutural da Eneida. Georg Knauer (1964a - artigo

${ }^{239}$ Sérvio ( $a d$ VII, v. 1 e $a d$ I, v. 1) também se refere a essa lição. 
reeditado em 1981) explica detalhadamente a presença dos cantos V-XII da Odisséia no arranjo dos seis cantos iniciais da Eneida e postula ainda a presença dos cantos XIII e XIV daquele poema nos VII e VIII deste, quando os heróis desses épicos alcançam o destino de suas jornadas (ambos desarmados, 1981, p. 883-884); e a Ilíada, por sua vez, revelar-se-ia como modelo estrutural somente a partir do canto IX da Eneida.

Acatando as ponderações de Knauer, Christian Kopff (1981) defende ser Odisséia o modelo principal da Eneida, cuja primeira metade fundar-se-ia no retorno de Odisseu para Ítaca e a segunda na reconquista da posição de pater familias e de chefe nessa ilha.

Francis Cairns (1989, cap. 8: “The Aeneid as Odyssey”, p. 177-214) trilha essa mesma linha de pensamento e propõe os seguintes vínculos: não haveria dúvida quanto à impressão digital da Odisséia na estrutura dos cantos I-IV da Eneida; nos jogos do canto V, estariam combinados os jogos feácios do canto VIII da Odisséia e os jogos fúnebres em honra de Pátroclo do canto XXIII da Ilíada; os cantos VI e VII corresponderiam respectivamente aos XI e XIII da Odisséia (o primeiro da segunda metade de cada poema), com Enéias e Odisseu chegando ao destino. Dessa forma, a Eneida seguiria em essência o modelo da Odisséia e lançaria mão de elementos significativos da Ilíada; e tal procedimento seria natural, pois tanto a Odisséia quanto a Eneida constituem vóotot.

Recentemente, no entanto, o professor Paulo Sérgio de Vasconcellos (2001, p.191207) sai em defesa da lição tradicional. Nessa tarefa, retomando o proêmio do canto I (v. 1-7), relembra a alusão feita à Ilíada pelo termo arma e a feita à Odisséia pelo termo uirum, bem como a subsequiente confirmação desse processo alusivo: "multum ille et terris iactatus et alto I ui superum saeuae memorem Iunonis ob iram" (v. 3-4) relaciona os errores de Enéias aos de Odisseu e "multa quoque et bello passus, dum conderet urbem" (v. 5) relaciona a guerra no Lácio às batalhas da Ilíada. Outro argumento apresentado a favor dessa imitatio bipartida (mas não redutora) seria uma correspondência entre os cantos de cada metade (exposta a seguir), sobretudo entre o I e o VII. Após examinar elementos textuais que corroboram seu posicionamento, Vasconcellos (p. 205) ressalva a existência de uma contaminatio dos poemas homéricos ao longo de toda a Eneida, com a predominância ora de um ora de outro.

Ao fim desse conspecto da primeira abordagem, um comentário a respeito do estudo de Brooks Otis (1964). Esse crítico (p. 217) reconhece que a divisão da Eneida em dois grupos de seis cantos pode ser percebida, em uma análise menos rigorosa, como uma 


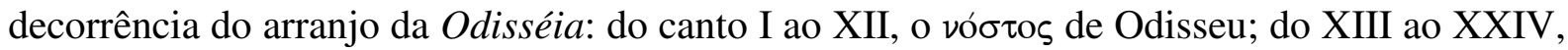
Odisseu em Ítaca. Apesar disso, Otis trabalha com a concepção tradicional e para ela cunha as expressões “Eneida odissíaca” e “Eneida iliádica”, largamente empregadas a partir de então.

Ao lado dessas discussões da arquitetura da epopéia de Virgílio em função de suas fontes, caminha a segunda abordagem, mais preocupada com a coerência interna do poema.

Bem cedo R. S. Conway (1928), deixando em segundo plano a influência externa ${ }^{240}$, empreende um exame da estrutura da Eneida com base nos dois princípios seguintes (guiados pela idéia de que Virgílio põe em prática amiúde em suas obras a noção de alternância): o primeiro consiste em um contraste entre pares sucessivos de cantos; o segundo em uma correspondência e em um contraste entre cantos correspondentes de cada metade. Acolhendo e desenvolvendo essa teoria de Conway, George Duckworth (1954, p. 11) deslinda uma progressão do conteúdo desse épico ancorada em uma alternância de elevação e diminuição de tensão e ainda em uma relação entre cantos correspondentes de cada metade:

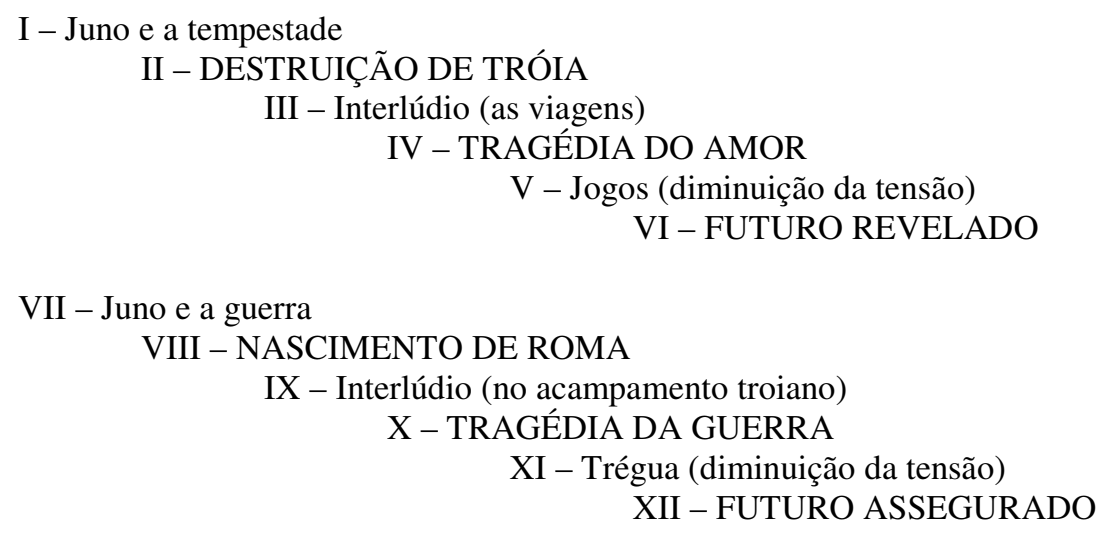

Em seguida (p. 12), fornece um esquema mais detalhado de paralelos e contrastes entre episódios dos cantos correspondentes de cada metade (incluindo os de Conway), demonstrando também a elevação e a diminuição da ação:

\begin{tabular}{|c|c|}
\hline I & VII \\
Juno e a tempestade & Juno e a guerra \\
& \\
Chegada a uma terra estranha & Chegada a uma terra estranha \\
Os troianos já são conhecidos & Os troianos já são conhecidos \\
Oferta de amizade & Oferta de amizade \\
Ilioneu fala por Enéias & Ilioneu fala por Enéias \\
\hline
\end{tabular}

\footnotetext{
${ }^{240}$ Na mesma época, MacKail (1930) chega a julgar pouco produtiva a concepção da estrutura da Eneida bipartida e fundada nos poemas homéricos; acredita que o arranjo dos episódios esteja, antes de tudo, subordinado a uma lógica interna, à ordenada progressão temática do poema.
} 


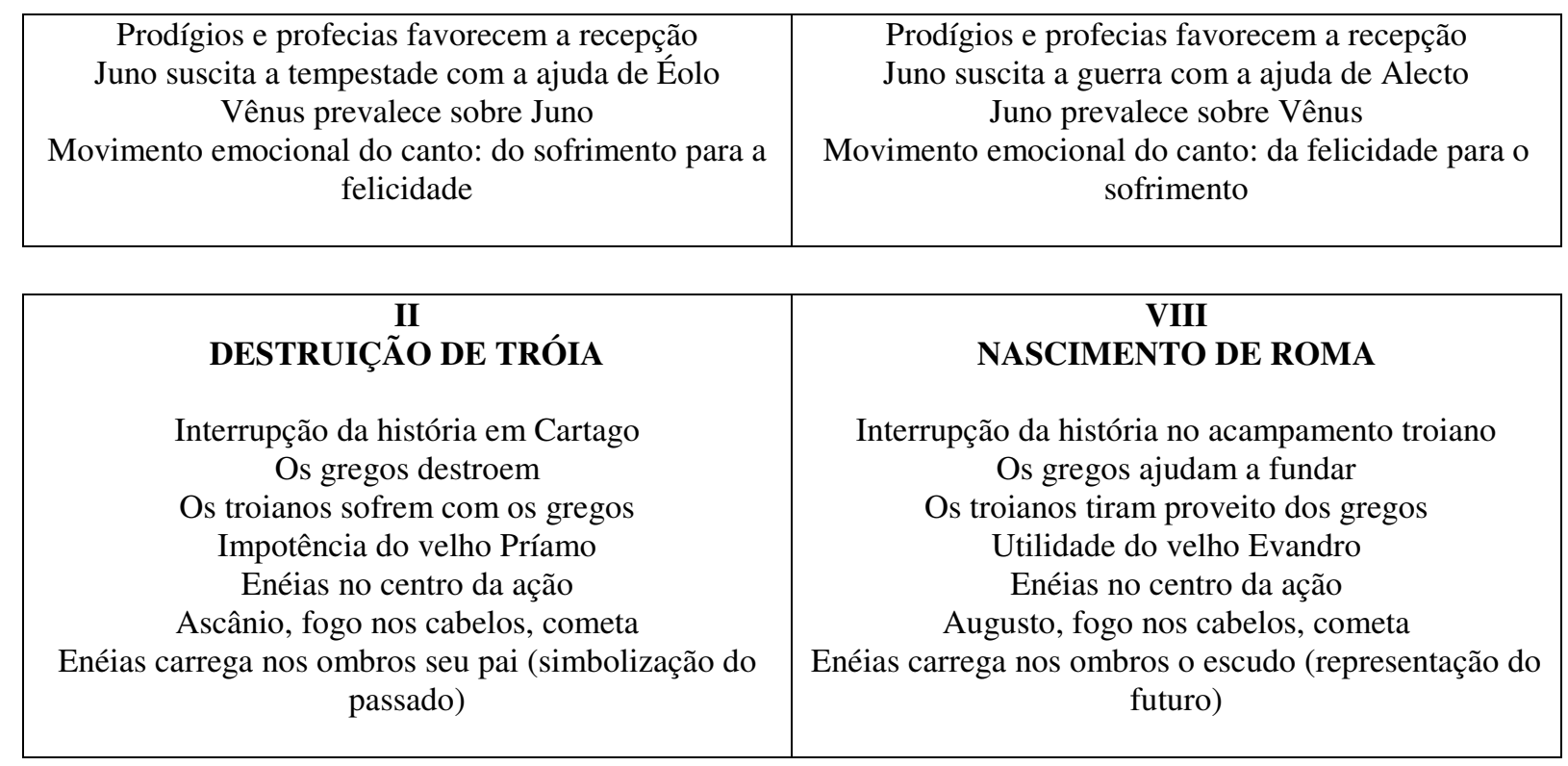

\begin{tabular}{|c|c|}
\hline III & IX \\
Interlúdio (as viagens) & Interlúdio (no acampamento troiano) \\
Papel menor de Enéias & Enéias ausente \\
Papel importante de Anquises & Papel importante de Ascânio \\
Os troianos sofrem com os gregos & Os troianos tiram proveito dos gregos \\
Heleno e Andrômaca (episódio alegre) & Niso e Euríalo (episódio trágico) \\
Perigos afastados: Ciclopes, Sicília, Caribdes & Perigo afastado: Turno no acampamento troiano \\
\hline
\end{tabular}

\begin{tabular}{|c|c|}
\hline $\begin{array}{c}\text { IV } \\
\text { TRAGÉDIA DO AMOR } \\
\text { (Dido) }\end{array}$ & $\begin{array}{c}\text { X } \\
\text { TRAGÉDIA DA GUERRA } \\
\text { (Palante, Lauso, Mezêncio) }\end{array}$ \\
\hline Vênus e Juno (em acordo) & Vênus e Juno (em conflito) \\
\hline Enéias enfrenta um conflito interior & Enéias enfrenta um conflito exterior \\
\hline $\mathrm{O}$ afeto gera dúvida & A pietas gera justiça \\
\hline Culpa de Dido (levando-a à morte) & Culpa de Turno (levando-o à morte no canto XII) \\
\hline $\begin{array}{c}\text { Reviravolta: a decisão de Enéias de partir e seu efeito } \\
\text { sobre Dido }\end{array}$ & $\begin{array}{c}\text { Reviravolta: a morte de Palante e seu efeito sobre } \\
\text { Enéias }\end{array}$ \\
\hline Suicídio de Dido, que não pode viver sem Enéias & Morte de Mezêncio, que não pode viver sem Lauso \\
\hline
\end{tabular}

\begin{tabular}{|c|c|}
\hline Jogos (diminuição da tensão) & XI \\
Jogos fúnebres & Trégua (diminuição da tensão) \\
O afeto gera dúvida & Funerais dos mortos em combate \\
Enéias apazigua a disputa & Enéias enfrenta um conflito exterior \\
Latino incapaz de evitar a dissensão \\
Aumento da tensão: queima dos barcos \\
Morte de Palinuro & Morte de Camila \\
\end{tabular}

\begin{tabular}{|c|c|}
\hline VI & XII \\
FUTURO REVELADO & FUTURO ASSEGURADO \\
\hline
\end{tabular}




\begin{tabular}{|c|c|}
\hline Enéias recebe sua missão & $\begin{array}{c}\text { Enéias cumpre sua missão } \\
\text { Progressão dramática: retardo e suspense, culminados } \\
\text { pela revelação do destino de Roma }\end{array}$ \\
$\begin{array}{c}\text { Anquises releva a história posterior dos romanos } \\
\text { Aratamento dramático do combate: retardo e suspense, } \\
\text { culminados pela vitória de Enéias }\end{array}$ \\
$\begin{array}{c}\text { A reconciliação de Júpiter e Juno propicia a criação } \\
\text { posterior dos romanos }\end{array}$ \\
A morte de Turno sela a antiga ordem
\end{tabular}

Não cabe aqui discutir a pertinência das simetrias e contrastes expostos nesse esquema - o qual possui, sem dúvida, pontos discutíveis, como o fato de a missão de Enéias lhe ser transmitida no canto VI, tal missão lhe é anunciada já no canto II através do sonho com Heitor.

Além de defender a lição tradicional de uma metade odissíaca e outra iliádica, Otis (1964) investiga a estruturação da Eneida na linha da segunda abordagem, considerando a formação e o sucesso do herói augustano como sendo o foco essencial da trama da epopéia. Aplicando à Eneida o motivo morte-ressurreição por ele identificado nas Bucólicas (especialmente na V) e nas Geórgicas (especialmente no episódio de Aristeu, IV, v. 281-558), Otis (p. 218-219) distingue a seguinte esquematização: a temática dos cantos I-V gravitaria ao redor das noções de derrota, paixão e incerteza; o canto VI, o ápice da preparação de Enéias para a guerra itálica, seria o da "morte e ressurreição" de Enéias, simbolizado pela catábase (que alude à de Orfeu); o canto VII seria o centro do poema, marcado pelo início da guerra na Itália, e desempenharia um papel semelhante ao da quinta bucólica e ao do episódio de Aristeu nas Geórgicas, consolidando a ressurreição de Enéias (após a catábase), dos troianos; os cantos VIII-XII, seguintes à ressurreição, caracterizariam a resolução e a vitória do herói augustano na Itália.

Os estudos de Otis demonstram que essas abordagens não são, na maior parte dos casos, excludentes. E toda essa gama de possibilidades interpretativas testemunha o labor que o poeta consagrou à arquitetura de seu poema ${ }^{241}$.

\footnotetext{
${ }^{241}$ Outros esquemas existem ainda dignos de nota. Jaques Perret (1952) filia o canto V aos acontecimentos de Cartago e com isso anuncia a seguinte bipartição: cantos I-V em torno de Cartago; cantos VI-XII na Itália. No livro Structural Patterns and Proportions in Virgil's Aeneid (1962), Duckworth propõe uma tripartição: os cantos I-IV centrar-se-iam na tragédia de Dido; os cantos V-VIII, no destino de Roma; os cantos IX-XII, na tragédia de Turno. Baseado em uma alternância entre luz e sombra no poema, Viktor Pöschl (1970) observa a seguinte tripartição: os cantos I-IV (tempestade, queda de Tróia, perda da pátria e do pai e morte de Dido) consumariam uma ambiência de escuridão; os cantos V-VIII (os jogos, a visão da futura glória romana, a descrição das tropas italianas, o triunfo de Augusto), uma ambiência de luz; os cantos IX-XII (a tragédia da guerra), uma ambiência de escuridão.
} 
A elas, pois, une-se agora uma nova interpretação para a arquitetura da primeira metade da Eneida, fundamentada, por sua vez, em relações estabelecidas com o ciclo troiano.

Como se viu, desde a Antigüidade distinguem-se contornos da Odisséia nos cantos I, III, IV, V e VI da Eneida, e estudos há muito detectam pegadas da Pequena Ilíada e do Saque de Ílion no canto II desse poema. E quanto aos demais poemas desse ciclo, sobretudo os perdidos? Na verdade, é incontestável a presença de épicos do ciclo troiano entre as fontes da Eneida, poucos estudiosos, porém, têm se dedicado a uma indagação mais abrangente do alcance de tal presença; nesse âmbito, as investigações são pontuais ou geralmente se concentram na influência da Ilíada e da Odisséia sobre a epopéia de Virgílio.

Como exemplo de trabalhos que procuram esquadrinhar as relações entre a Eneida e os poemas homéricos, elevam-se os de Knauer (1964a-b, 1981) com as seguintes finalidades: ultrapassar a indicação de modelos e fontes para episódios isolados da Eneida e desvelar com mais propriedade nesse poema sentidos e funções de passagens e estruturas provenientes de Homero.

Nicholas Horsfall (1979a-b, 1983, 1987), por sua parte, vai um pouco além da esfera homérica ao averiguar a lenda de Enéias também nas demais epopéias do ciclo troiano e ao discutir as Tabulae Iliacae, sobretudo a Capitolina.

$\mathrm{Na}$ esteira de pesquisas como as de Knauer e Horsfall, Kopff publicou em 1981 um estudo de liames entre a Eneida e o ciclo troiano, com a intenção de verificar de que forma Virgílio teria recriado para sua época não apenas a Ilíada e a Odisséia, mas toda uma tradição épica vinculada a Tróia. Raro no gênero, esse estudo alicerça muitas discussões empreendidas neste capítulo.

Depois de sumariar os épicos perdidos do ciclo troiano, Kopff (1981) propõe uma lista de referências a personagens ou episódios desses poemas, catalogadas por canto da Eneida, contendo algumas explícitas e outras duvidosas (p. 924-926); logo em seguida, apresenta uma nova lista, organizando as referências por poema do ciclo (p. 927).

Tomando por base tais listas, o quadro a seguir contém indicações de Kopff (apenas aquelas coerentes com a reconstituição dos épicos feita no capítulo I) e outras alusões por ele não relacionadas:

\begin{tabular}{|c|c|c|c|}
\hline $\begin{array}{c}\text { Poemas do } \\
\text { ciclo troiano }\end{array}$ & $\begin{array}{c}\text { Episódio/ } \\
\text { personagem }\end{array}$ & $\begin{array}{c}\text { Referência na } \\
\text { Eneida }\end{array}$ & Conteúdo da referência \\
\hline
\end{tabular}




\begin{tabular}{|c|c|c|c|}
\hline \multirow{9}{*}{$\begin{array}{l}\text { Cantos } \\
\text { Cíprios }\end{array}$} & $\begin{array}{l}\text { Nascimento de } \\
\text { Aquiles }\end{array}$ & VI, v. 89-90 & a Sibila alude ao nascimento de Aquiles \\
\hline & iudicium Paridis & I, v. 27 & Uma das causas do rancor de Juno \\
\hline & & VI, v. 93-94 & $\begin{array}{l}\text { A Sibila alude a uma guerra causada pela união de uma } \\
\text { mulher com um estrangeiro }\end{array}$ \\
\hline & Rapto de Helena & VII, v. 363-364 & $\begin{array}{l}\text { Ao reclamar de Latino, que deseja entregar Lavínia em } \\
\text { casamento a Enéias, Amata cita o rapto de Helena por } \\
\text { Páris }\end{array}$ \\
\hline & & X, v. 88-93 & $\begin{array}{l}\text { Discurso de Juno no Olimpo: Páris jogou os gregos } \\
\text { contra os troianos }\end{array}$ \\
\hline & Castor e Pólux & VI, v. 121-122 & Alusão ao sacrifício de Pólux pelo irmão \\
\hline & $\begin{array}{l}\text { Sacrifício de } \\
\text { Ifigênia }\end{array}$ & II, v. 116 & Discurso de Sínon \\
\hline & Morte de Tróilo & I, v. 474-478 & Pintura V \\
\hline & $\begin{array}{l}\text { Morte de } \\
\text { Palamedes }\end{array}$ & II, v. 81-93 & Discurso de Sínon: Palamedes morto por Ulisses \\
\hline \multirow{3}{*}{ Etiope } & $\begin{array}{l}\text { Pentesiléia, } \\
\text { amazonas }\end{array}$ & $\begin{array}{l}\text { I, v. } 490-493 \\
\text { XI, v. } 659-663\end{array}$ & $\begin{array}{l}\text { Pintura X } \\
\text { Símile comparando Camila às amazonas (à Hipólita e à } \\
\text { Pentesiléia) }\end{array}$ \\
\hline & Mêmnon & $\begin{array}{l}\text { I, v. } 489 \\
\text { I, v. } 751 \\
\text { VIII, v. 383-384 }\end{array}$ & $\begin{array}{l}\text { Pintura IX } \\
\text { Dido pergunta sobre as armas de Mêmnon } \\
\text { Vênus pede a Vulcano armas para Enéias, como antes } \\
\text { Tétis e Aurora pediram para Aquiles e Mêmnon }\end{array}$ \\
\hline & $\begin{array}{l}\text { Páris mata } \\
\text { Aquiles }\end{array}$ & VI, v. 57-58 & $\begin{array}{l}\text { Em presença da Sibila, Enéias invoca Apolo alegando } \\
\text { que o deus ajudou Páris a matar Aquiles }\end{array}$ \\
\hline \multirow[t]{2}{*}{$\begin{array}{l}\text { Pequena } \\
\text { Ilíada }\end{array}$} & $\begin{array}{l}\text { Roubo do } \\
\text { paládio }\end{array}$ & IX, v. $150-152$ & $\begin{array}{l}\text { Discurso de Sínon: para expiar o sacrílego roubo do } \\
\text { paládio por Diomedes e Odisseu, os gregos teriam } \\
\text { confeccionado o cavalo de madeira } \\
\text { Turno encoraja seus homens aludindo ao roubo do } \\
\text { paládio e ao massacre que Odisseu e Diomedes fazem } \\
\text { para sair de Tróia com a estatueta }\end{array}$ \\
\hline & $\begin{array}{l}\text { Morte de } \\
\text { Astíanax }\end{array}$ & III, v. 489-491 & $\begin{array}{l}\text { No Epiro, Andrômaca, vendo Ascânio, relembra } \\
\text { Astíanax (supostamente morto por Neoptótemo) }\end{array}$ \\
\hline \multirow[b]{2}{*}{$\begin{array}{l}\text { Saque de } \\
\text { Ílion }\end{array}$} & Cavalo de Tróia & $\begin{array}{l}\text { Canto II } \\
\text { IX, v. } 152 \\
\text { VI, v. } 515-516\end{array}$ & $\begin{array}{l}\text { Turno alude ao cavalo recheado de guerreiros } \\
\text { A alma de Deífobo alude ao cavalo cheio de homens } \\
\text { armados }\end{array}$ \\
\hline & Cassandra & $\begin{array}{l}\text { II, v. } 246-247 \\
\text { X, v. } 68\end{array}$ & $\begin{array}{l}\text { Cassandra anuncia a catástrofe, mas não crêem nela } \\
\text { Discurso de Juno no Olimpo: Enéias teria ido à Itália }\end{array}$ \\
\hline
\end{tabular}




\begin{tabular}{|c|c|c|c|}
\hline & & & impulsionado pela fúria profética de Cassandra \\
\hline & Tomada de Tróia & $\begin{array}{l}\text { Canto II } \\
\text { VI, v. 509-529 }\end{array}$ & A alma de Deífobo relata o assalto da cidade \\
\hline & $\begin{array}{l}\text { Incêndio de } \\
\text { Tróia }\end{array}$ & $\begin{array}{l}\text { VII, v. 295-297 } \\
\text { IX, v. 144-145 }\end{array}$ & $\begin{array}{l}\text { Juno impreca contra os troianos e alude ao incêndio da } \\
\text { cidade } \\
\text { Turno lembra o incêndio que destruiu os muros } \\
\text { sagrados de Tróia, feitos por Netuno }\end{array}$ \\
\hline & $\begin{array}{l}\text { Morte de } \\
\text { Deífobo }\end{array}$ & VI, v. 520-529 & $\begin{array}{l}\text { A alma de Deífobo conta como Menelau invadiu seu } \\
\text { palácio e o matou, com a ajuda de Helena }\end{array}$ \\
\hline & $\begin{array}{l}\text { Morte de } \\
\text { Astíanax }\end{array}$ & III, v. 489-491 & $\begin{array}{l}\text { No Epiro, Andrômaca, vendo Ascânio, relembra } \\
\text { Astíanax (morto por Odisseu no Saque de Ílion) }\end{array}$ \\
\hline & $\begin{array}{l}\text { Sacrifício de } \\
\text { Polixena }\end{array}$ & III, v. 321-324 & $\begin{array}{l}\text { Andrômaca comenta a sorte de Polixena, imolada sobre } \\
\text { a tumba de Aquiles }\end{array}$ \\
\hline Retornos & Ájax lócrio & $\begin{array}{l}\text { I, v. 39-45; } \\
\text { III, v. } 399 \\
\text { XI, v. 259-260 }\end{array}$ & $\begin{array}{l}\text { Juno cita o castigo imposto por Atena ao Ájax filho de } \\
\text { Oileu no retorno dos gregos } \\
\text { Heleno cita Narícia, cidade fundada por homens desse } \\
\text { Ájax que voltavam de Tróia } \\
\text { Diomedes cita a tempestade lançada por Atena contra a } \\
\text { frota do Ájax lócrio }\end{array}$ \\
\hline & $\begin{array}{l}\text { Morte de } \\
\text { Agamêmnon }\end{array}$ & XI, v. 266-268 & $\begin{array}{l}\text { Diomedes evoca a morte de Agamêmnon e o adultério } \\
\text { de Clitemnestra }\end{array}$ \\
\hline & $\begin{array}{l}\text { Menelau no } \\
\text { Egito }\end{array}$ & XI, v. 261-263 & Diomedes cita a visita de Menelau a Proteu \\
\hline & $\begin{array}{l}\text { Retorno de } \\
\text { Neoptólemo }\end{array}$ & III, v. 294-505 & $\begin{array}{l}\text { No epiro, Heleno e Andrômaca relatam o retorno de } \\
\text { Neoptólemo }\end{array}$ \\
\hline & $\begin{array}{l}\text { Vingança de } \\
\text { Náuplio }\end{array}$ & III, v. 121-123 & $\begin{array}{l}\text { Em Creta, alude-se à vingança maquinada por Náuplio } \\
\text { contra Idomeneu }\end{array}$ \\
\hline
\end{tabular}

Esse quadro comprova que a presença de temáticas das epopéias perdidas do ciclo troiano na Eneida vai muito além do episódio das pinturas no templo de Juno. Tal fato é perfeitamente compreensível, uma vez que o épico de Virgílio integra esse ciclo; ademais, a maior parte das passagens assinaladas corresponde a breves indicações de mitos da guerra de Tróia já bastante difundidos, constituintes de um senso comum; nesse caso, assomam tanto nas epopéias desse ciclo quanto em diversos poemas que bebem do repertório de tais mitos. Outras referências, no entanto, são mais elaboradas, como as urdidas pelas pinturas no templo de Juno; nessa perspectiva, destacam-se ainda o canto II, o relato de Deífobo no canto VI (v. 
509-529), a exortação feita por Turno no canto IX (v. 128-158) e o discurso de Diomedes no canto XI (v. 252-293).

No caso de Turno, como acontece no episódio das pinturas, poemas do ciclo troiano emergem em seqüencia. Ao encorajar seus guerreiros a atacarem o acampamento inimigo, Turno toma algumas ocorrências desse ciclo como argumento: inicialmente expressa a fatalidade em si, a queda de Tróia, mencionando o incêndio que destruiu os muros erigidos por Netuno (v. 144-145) - tema do Saque de Ílion. Pouco depois, ao designar recursos e atos gregos para aniquilar a cidade, alude a poemas do ciclo em ordem cronológica (embora descontínua): as armas de Aquiles fabricadas por Vulcano (v. 148) e a grande quantidade de barcos (v. 148-149) trazem à baila a Ilíada (respectivamente os cantos XVIII e II); o roubo do paládio à noite e o massacre perpetrado por Odisseu e Diomedes para sair de Tróia com a estatueta (v. 150-152) remetem à Pequena Ilíada; o ardil do cavalo de madeira (v. 152), ao Saque de Ílion.

Em seu discurso à embaixada latina, Diomedes resume os retornos do Ájax lócrio, de Menelau, de Ulisses e de Agamêmnon, cita os de Neoptólemo e Idomeneu e enfim aborda seu próprio retorno infeliz (XI, v. 255-277).

Tal qual Enéias nos cantos II e III, Deífobo e Diomedes narram acontecimentos por eles vivenciados, e as narrativas resultantes (como a de Enéias) reconstituem episódios do ciclo troiano. Nessa linha de raciocínio, Horsfall (ad XI, v. 243-295), comentando os sete retornos desfiados por Diomedes, constata que eles configuram, de certa maneira, um sumário de assuntos dos Retornos.

Essa constatação testemunha a familiaridade de Virgílio com os Retornos (no mínimo em forma epitomada) e introduz a estratégia textual a ser explorada neste capítulo: uma "reedição" do ciclo troiano na Eneida. E, ao tracejar uma das formas de difusão dos épicos cíclicos, o epítome, Virgílio comunica indícios não apenas de estratégias empregadas em sua epopéia mas também do material com o qual lidou.

Tal "reedição" participa da arquitetura do poema. Com efeito, a segunda série de pinturas do templo de Juno desvela os Cantos Cíprios, a Ilíada e o Etíope; essa sequiência recebe uma continuidade nos seis cantos iniciais: o canto II põe em cena a Pequena Ilíada e o Saque de Ílion; os cantos III, I-IV, V e VI, os Retornos e a Odisséia. Destarte, excetuando-se a Telegonia, Virgílio "reedita" nesses cantos o ciclo troiano em ordem, agora em função de 
Enéias: esse herói narra a queda de Tróia, da qual tomou parte; em seguida, narra e vivencia

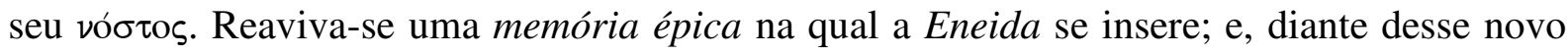
horizonte de significação, o poema possibilita a concretização de mais sentidos.

Uma vez que essa arquitetura já salta aos olhos, em lugar de demonstrá-la, o objetivo deste capítulo passa a ser aprofundá-la. Nessa tarefa, o desafio maior consiste na análise da efetiva participação das epopéias perdidas desse ciclo nessa arquitetura, uma vez que as influências estruturais dos poemas homéricos sobre a Eneida são bem atestadas. Por conseguinte, a investigação concentra-se mais nesse desafio. No que diz respeito ao papel estrutural dos poemas homéricos, notadamente o da Odisséia, recorre-se a outros estudos, os quais em certos casos vêm acompanhados de uma apreciação. Além disso, são abordados alguns assuntos não diretamente ligados à estruturação, mas relevantes para discussões desenvolvidas em capítulos anteriores.

Quanto à organização do capítulo, a análise preserva a ordem dos seis cantos iniciais da Eneida e divide-se em três partes: à primeira, intitulada "A instituição de uma arquitetura fundada no ciclo troiano", cabe reafirmar o papel do canto I nesse projeto arquitetônico e abrir espaço a uma breve discussão da imitatio efetuada por Virgílio; a segunda, "A queda de

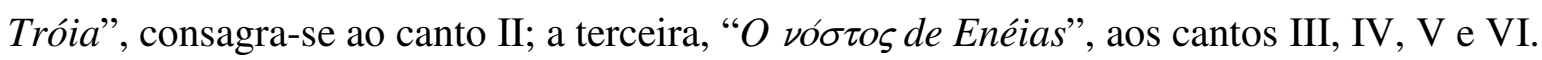




\section{III.1 - A instituição de uma arquitetura fundada no ciclo troiano}

Nesta investigação, o canto I reveste-se de grande importância, nele se encontram as pinturas do templo de Juno, a porta que leva o receptor ao encontro da seqüência de poemas do ciclo troiano.

Com base no detalhado estudo de Knauer (1981) acerca das relações entre a Eneida e os poemas homéricos, organizou-se o quadro subseqüente com a composição desse canto, o qual propicia uma reflexão sobre o diálogo entre o episódio das pinturas do templo de Juno e seu modelo:

\begin{tabular}{|c|c|c|c|}
\hline Eneida & Conteúdo & Fonte & Conteúdo \\
\hline v. 34-156 & $\begin{array}{l}\text { Rancor de Juno, tempestade, Posídon } \\
\text { acalma as águas }\end{array}$ & $\begin{array}{l}\text { Odisséia, } \mathrm{V} \\
\text { v. } 268-399\end{array}$ & $\begin{array}{l}\text { Rancor de Posídon, tempestade, } \\
\text { Atena acalma as águas }\end{array}$ \\
\hline v. $157-222$ & $\begin{array}{l}\text { Enéias e seus homens fazem o } \\
\text { reconhecimento de Cartago; } \\
\text { Mercúrio predispõe os púnicos e } \\
\text { Dido para receberem bem os troianos }\end{array}$ & $\begin{array}{l}\text { Odisséia, X } \\
\text { v. 135-306 }\end{array}$ & $\begin{array}{l}\text { Odisseu faz o reconhecimento da ilha } \\
\text { de Circe; Hermes lhe aparece para } \\
\text { lhe ensinar a se proteger dos feitiços } \\
\text { de Circe }\end{array}$ \\
\hline v. $223-304$ & $\begin{array}{l}\text { No Olimpo: Vênus pede a proteção } \\
\text { de Júpiter para Enéias; anúncio do } \\
\text { destino desse herói e dos romanos }\end{array}$ & $\begin{array}{c}\text { Bellum } \\
\text { Poenicum, I }\end{array}$ & $\begin{array}{l}\text { Segundo Macróbio (Sat., VI, 2, 31), a } \\
\text { tempestade, o diálogo de Júpiter e } \\
\text { Vênus e o anúncio do destino de } \\
\text { Enéias viriam de Névio }\end{array}$ \\
\hline v. $305-417$ & $\begin{array}{l}\text { Vênus aparece a Enéias vestida de } \\
\text { caçadora e explica onde estão, a } \\
\text { história de Dido e como chegar à } \\
\text { corte, depois desaparece e envolve } \\
\text { Enéias em névoa }\end{array}$ & $\begin{array}{l}\text { Odisséia, VII } \\
\text { v. 18-81 }\end{array}$ & $\begin{array}{l}\text { Atena disfarçada de virgem aparece a } \\
\text { Odisseu, conta a história de Arete e } \\
\text { mostra o caminho da corte, depois } \\
\text { desaparece e envolve Odisseu em } \\
\text { névoa (Odisséia, VII, v. 14-15) }\end{array}$ \\
\hline v. $418-497$ & $\begin{array}{l}\text { Enéias entra em Cartago, no bosque e } \\
\text { no templo de Juno }\end{array}$ & $\begin{array}{l}\text { Odisséia, VII } \\
\text { v. } 82-135\end{array}$ & $\begin{array}{l}\text { Odisseu entra no palácio de Alcino e } \\
\text { admira a beleza do local, o trabalho } \\
\text { artístico das mulheres }\end{array}$ \\
\hline (v. $453-465$ & $\begin{array}{l}\text { Enéias vê as pinturas e chora } \\
\text { diante da primeira imagem }\end{array}$ & $\begin{array}{l}\text { Odisséia, VIII } \\
\quad \text { v. } 72-92\end{array}$ & $\begin{array}{l}\text { Primeira canção de Demódoco: } \\
\text { querela entre Odisseu e Aquiles; } \\
\text { choro de Odisseu) }\end{array}$ \\
\hline v. $498-504$ & Símile de Dido e Diana & $\begin{array}{l}\text { Odisséia, VI } \\
\text { v. 102-108 }\end{array}$ & Símile de Nausícaa e Ártemis \\
\hline v. $505-519$ & $\begin{array}{l}\text { Dido recebe bem os troianos e } \\
\text { pergunta-lhes de onde vieram }\end{array}$ & $\begin{array}{l}\text { Odisséia, VII } \\
\text { v. 136-239 }\end{array}$ & $\begin{array}{l}\text { Os reis recebem bem Odisseu, e } \\
\text { Arete pergunta-lhe de onde veio }\end{array}$ \\
\hline v. $520-560$ & $\begin{array}{l}\text { Discurso de Ilioneu, contando o } \\
\text { percurso da Sicília até Cartago }\end{array}$ & $\begin{array}{l}\text { Odisséia, VII } \\
\text { v. 240-297 }\end{array}$ & $\begin{array}{l}\text { Discurso de Odisseu: da Ogígia até a } \\
\text { Feácia }\end{array}$ \\
\hline v. $561-578$ & Dido promete ajudar os troianos & $\begin{array}{l}\text { Odisséia, VII } \\
\text { v. 298-328 }\end{array}$ & Alcino promete ajudar Odisseu \\
\hline
\end{tabular}




\begin{tabular}{|c|c|c|c|}
\hline v. 579-642 & $\begin{array}{l}\text { Alívio de Enéias, a nuvem se rompe, } \\
\text { o herói se apresenta, Dido o louva, o } \\
\text { conduz ao interior do palácio e } \\
\text { prepara um banquete }\end{array}$ & $\begin{array}{l}\text { Odisséia, VIII } \\
\text { v. } 236-265\end{array}$ & $\begin{array}{l}\text { Depois dos jogos, Alcino convida } \\
\text { Odisseu a participar das festividades: } \\
\text { danças e canto, com Demódoco }\end{array}$ \\
\hline (v. 588-593 & Vênus faz Enéias mais belo e jovem & $\begin{array}{l}\text { Odisséia, VIII } \\
\text { v. } 18-23\end{array}$ & Atena faz Odisseu mais belo) \\
\hline v. $643-722$ & $\begin{array}{l}\text { Enéias manda Acates buscar Ascânio } \\
\text { e presentes; (artimanha de Vênus } \\
\text { para fazer Dido se apaixonar por } \\
\text { Enéias); Dido recebe os presentes e } \\
\text { conhece Ascânio (Cupido) }\end{array}$ & $\begin{array}{l}\text { Odisséia, VIII } \\
\text { v. 385-432 }\end{array}$ & $\begin{array}{l}\text { Os feácios dão presentes a Odisseu; } \\
\text { Alcino oferta uma taça de ouro }\end{array}$ \\
\hline $\begin{array}{l}\text { v. } 723-740 \\
\text { v. } 740-747\end{array}$ & $\begin{array}{l}\text { O banquete começa; } \\
\text { Canção de Iopas }\end{array}$ & $\begin{array}{l}\text { Odisséia, VIII } \\
\text { v. 266-366 }\end{array}$ & $\begin{array}{l}\text { Segunda canção de Demódoco: } \\
\text { amores de Afrodite e Ares }\end{array}$ \\
\hline v. $748-756$ & $\begin{array}{l}\text { Dido pede a Enéias que conte sua } \\
\text { história }\end{array}$ & $\begin{array}{l}\text { Odisséia, VIII } \\
\text { v. 536-586 }\end{array}$ & $\begin{array}{l}\text { Alcino pede a Odisseu que conte sua } \\
\text { história }\end{array}$ \\
\hline
\end{tabular}

O canto I da Eneida navega em águas da Odisséia, seus episódios condensam, de forma geral, os cantos V-VIII do poema homérico. E, em seus últimos versos, a solicitação de Dido coloca em paralelo o relato de Enéias (cantos II e III) e o de Odisseu (cantos IX-XII). Com isso, a Odisséia implanta-se desde já como modelo estrutural dos três primeiros cantos da Eneida.

Tal fato forja uma compleição arquitetural interessante e significativa para esta investigação: o episódio das pinturas do templo de Juno acontece no interior de uma parte odissíaca e implementa uma evocação do ciclo troiano que se desenrola nos cantos da primeira metade do poema; em outras palavras, dentro do horizonte odissíaco dos seis cantos iniciais da Eneida, delineia-se uma "reedição" do ciclo troiano.

Quando se observa a correspondência do episódio das pinturas na Odisséia, vem à superfície a inspiração de um procedimento empregado por Virgílio. Esse episódio se relaciona com a primeira canção de Demódoco. Empregando um procedimento metapoético, a Odisséia lança mão de um aedo para recitar um episódio épico em uma epopéia, pondo em cena uma típica performance da tradição oral para a divulgação desse gênero. Há também metapoesia na Eneida: pinturas inspiradas em passagens de poemas épicos evocam epopéias. Além disso, Virgílio recorre à arte da memória para compor esse episódio e a põe em cena.

Destarte, Virgílio identifica a estratégia metapoética presente na Odisséia e a redimensiona em seu poema, substituindo o processo de difusão artística, ou seja, a 
performance oral por uma linguagem pictórica, e pondo em cena uma grande fonte de recursos poéticos de sua época, a retórica.

O desvelar dessa imitatio ilumina mais um argumento a favor da tese de uma consciente encenação da mnemotécnica no episódio das pinturas do templo de Juno.

\section{III.2 - A queda de Tróia}

No capítulo I, verificou-se que o saque de Tróia aparece de forma sintetizada na Odisséia (VIII, v. 492-520) e que se desenvolvia na Pequena Ilíada e no Saque de Ílion. No que tange à Eneida, considera-se o canto II uma recriação dessa temática; convém então examinar como aqui se evocam esses épicos do ciclo troiano.

O quadro a seguir dispõe lado a lado o tratamento da queda de Tróia nos quatro poemas em questão, exibindo as relações, quando existentes, entre seus episódios:

\begin{tabular}{|c|c|c|c|c|}
\hline \multicolumn{2}{|c|}{ Canto II da Eneida } & Odisséia & Pequena Ilíada & Saque de Ílion \\
\hline Episódios & Versos & Episódios & Episódios & Episódios \\
\hline $\begin{array}{l}\text { Descoberta do cavalo e } \\
\text { deliberação sobre o } \\
\text { destino da máquina: } \\
\text { Timetes aconselha } \\
\text { derrubarem o muro e } \\
\text { levarem-na para a cidade; } \\
\text { Cápis e outros, atirá-la ao } \\
\text { mar, atearem-lhe fogo ou } \\
\text { sondarem-lhe o ventre. }\end{array}$ & $13-39$ & $\begin{array}{l}\text { Descoberta do cavalo } \\
\text { pelos troianos e sua } \\
\text { condução para a acrópole; } \\
\text { deliberação sobre o } \\
\text { destino da máquina, na } \\
\text { qual afloram três posições } \\
\text { (verificar com lanças de } \\
\text { bronze o interior do } \\
\text { animal, atirá-lo de um } \\
\text { precipício ou guardá-lo } \\
\text { como oferenda aos } \\
\text { deuses); vitória da terceira } \\
\text { posição; }\end{array}$ & $\begin{array}{l}\text { Possível deliberação } \\
\text { fora da cidade, seguida } \\
\text { da demolição do muro } \\
\text { para a entrada do cavalo. }\end{array}$ & $\begin{array}{l}\text { Ao encontrar o cavalo de } \\
\text { madeira no campo } \\
\text { abandonado pelos gregos, } \\
\text { os troianos questionam-se } \\
\text { sobre o significado de tal } \\
\text { engenho e debatem a } \\
\text { respeito do que fazer com } \\
\text { ele: uns propõem atirá-lo } \\
\text { de um precipício, outros } \\
\text { atear-lhe fogo; outros, } \\
\text { porém, consideram-no um } \\
\text { objeto sagrado que deve } \\
\text { ser dedicado à deusa } \\
\text { Atena. Ao fim, vence a } \\
\text { opinião destes últimos. }\end{array}$ \\
\hline $\begin{array}{l}\text { Posicionamento de } \\
\text { Laocoonte sobre o cavalo }\end{array}$ & $40-56$ & & & $\begin{array}{l}\text { Possível posicionamento } \\
\text { de Cassandra e Laocoonte } \\
\text { sobre o cavalo }\end{array}$ \\
\hline $\begin{array}{r}\text { Sínon (v. 57-198) } \\
\text { Sínon encontrado nas } \\
\text { imediações do cavalo }\end{array}$ & $57-62$ & & $\begin{array}{l}\text { Concluído o cavalo, } \\
\text { alguns dos principais } \\
\text { heróis escondem-se em } \\
\text { seu ventre. Os demais } \\
\text { gregos queimam o } \\
\text { acampamento e partem } \\
\text { para a ilha de Tênedos, } \\
\text { deixando no local } \\
\text { apenas Sínon, } \\
\text { incumbido de lhes guiar } \\
\text { à noite com o sinal de } \\
\text { uma tocha. }\end{array}$ & $\begin{array}{l}\text { Prosseguindo com o plano } \\
\text { de invasão, Sínon } \\
\text { consegue penetrar em } \\
\text { Ílion com seu fingimento. }\end{array}$ \\
\hline
\end{tabular}




\begin{tabular}{|c|c|c|c|c|}
\hline $\begin{array}{l}\text { Alusão ao roubo do } \\
\text { paládio }\end{array}$ & $162-194$ & & $\begin{array}{l}\text { Odisseu e Diomedes } \\
\text { penetram em Ílion e } \\
\text { roubam o paládio, a } \\
\text { estátua protetora da } \\
\text { cidade (fato anterior à } \\
\text { partida para Tênedos) }\end{array}$ & \\
\hline $\begin{array}{l}\text { Prodígio das serpentes: } \\
\text { morrem Laocoonte e seus } \\
\text { dois filhos. }\end{array}$ & $199-233$ & & & $\begin{array}{l}\text { Durante as celebrações, } \\
\text { Apolo envia-lhes um sinal } \\
\text { funesto: duas serpentes, } \\
\text { vindas de ilhas próximas } \\
\text { rastejando sobre as águas, } \\
\text { lançam-se sobre } \\
\text { Laocoonte e um de seus } \\
\text { dois filhos e os matam. }\end{array}$ \\
\hline $\begin{array}{l}\text { Entrada do cavalo na } \\
\text { cidade com a demolição } \\
\text { dos muros (Diuidimus } \\
\text { muros, v. 234). }\end{array}$ & 234-249 & $\begin{array}{l}\text { Condução do cavalo para } \\
\text { a acrópole sem alusão à } \\
\text { destruição dos muros } \\
\text { (antes da deliberação } \\
\text { sobre o destino dele) }\end{array}$ & $\begin{array}{l}\text { Decididos a introduzir a } \\
\text { máquina na cidade, } \\
\text { demolem uma parte do } \\
\text { muro e pela abertura } \\
\text { fazem-na passar. }\end{array}$ & $\begin{array}{l}\text { Possível condução do } \\
\text { cavalo para o interior da } \\
\text { cidade antes da } \\
\text { deliberação sobre seu } \\
\text { destino e sem alusão à } \\
\text { destruição dos muros }\end{array}$ \\
\hline $\begin{array}{l}\text { Finda o dia, os troianos } \\
\text { adormecem de cansaço, e } \\
\text { o plano grego entra em } \\
\text { ação sob uma lua nova: } \\
\text { partem de Tênedos; ação } \\
\text { de Sínon; os guerreiros } \\
\text { saem do cavalo por uma } \\
\text { corda; início da tomada } \\
\text { da cidade. }\end{array}$ & $250-267$ & $\begin{array}{l}\text { Saída dos guerreiros do } \\
\text { interior do cavalo e o } \\
\text { assalto da cidade }\end{array}$ & $\begin{array}{l}\text { Entretanto, no meio da } \\
\text { noite, sob uma lua } \\
\text { brilhante, Sínon cumpre } \\
\text { sua tarefa. }\end{array}$ & $\begin{array}{l}\text { No momento adequado, } \\
\text { Sínon faz sinal com uma } \\
\text { tocha para os gregos, que } \\
\text { retornam de Tênedos. } \\
\text { Adormecidos os troianos, } \\
\text { os guerreiros saem do } \\
\text { ventre do imenso cavalo } \\
\text { com suas armas e } \\
\text { favorecem a entrada do } \\
\text { exército. }\end{array}$ \\
\hline $\begin{array}{l}\text { (Epeu é o fabricante do } \\
\text { cavalo }\end{array}$ & 264 & $\begin{array}{l}\text { Construção do cavalo por } \\
\text { Epeu, com o auxílio de } \\
\text { Atena }\end{array}$ & $\begin{array}{l}\text { Seguindo instruções de } \\
\text { Atena, Epeu começa a } \\
\text { construir a máquina.) }\end{array}$ & \\
\hline $\begin{array}{l}\text { Sonho de Enéias com o } \\
\text { fantasma de Heitor }\end{array}$ & $268-297$ & & & \\
\hline \begin{tabular}{l}
\multicolumn{1}{c}{$\begin{array}{c}\text { Saque da Tróia } \\
\text { (v. 298-558) }\end{array}$} \\
Destruição do palácio de \\
Deífobo (no canto VI (v. \\
494-529), o fantasma de \\
Deífobo narra a Enéias \\
detalhes de sua morte)
\end{tabular} & $310-312$ & $\begin{array}{l}\text { Invasão do palácio de } \\
\text { Deífobo por Ulisses e } \\
\text { Menelau }\end{array}$ & & $\begin{array}{l}\text { Começa então o massacre, } \\
\text { os gregos caem sobre os } \\
\text { inimigos. } \\
\text { Menelau encontra Helena } \\
\text { e Deífobo, mata este e a } \\
\text { conduz aos barcos }\end{array}$ \\
\hline $\begin{array}{l}\text { Cassandra arrastada do } \\
\text { templo de Minerva. }\end{array}$ & $402-406$ & & & $\begin{array}{l}\text { Ájax, filho de Oileu, } \\
\text { persegue Cassandra, que } \\
\text { se agarra a uma estátua } \\
\text { de madeira da deusa } \\
\text { Atena. Ele, no entanto, a } \\
\text { arrasta, usando de } \\
\text { tamanha violência que } \\
\text { acaba arrancando a } \\
\text { imagem de seu altar. }\end{array}$ \\
\hline
\end{tabular}




\begin{tabular}{|c|c|c|c|}
\hline $\begin{array}{l}\text { Ação de Corebo, morto } \\
\text { por Peneleu } \\
\text { Príamo morto por } \\
\text { Neoptólemo junto do } \\
\text { altar dos Penates, no } \\
\text { pátio do palácio }\end{array}$ & $\begin{array}{l}424-426 \\
506-558\end{array}$ & $\begin{array}{l}\text { Diomedes mata Corebo } \\
\text { durante } \mathrm{o} \text { assalto }\end{array}$ & $\begin{array}{l}\text { Tentando escapar, Príamo } \\
\text { refugia-se junto do altar } \\
\text { de Zeus Herceio, mas } \\
\text { Neoptólemo o mata. }\end{array}$ \\
\hline Enéias vê Helena & $559-587$ & & \\
\hline $\begin{array}{l}\text { Vênus demove Enéias da } \\
\text { idéia de matar Helena e } \\
\text { explica-lhe as razões da } \\
\text { queda de Tróia }\end{array}$ & $588-633$ & & \\
\hline Lamentação de Anquises & $634-678$ & & \\
\hline Prodígio com Ascânio & $679-686$ & & \\
\hline $\begin{array}{l}\text { O trovão de Júpiter e a } \\
\text { estrela cadente }\end{array}$ & $687-698$ & & \\
\hline $\begin{array}{l}\text { Fuga de Tróia para o Ida, } \\
\text { em decorrência de } \\
\text { prodígios }\end{array}$ & $699-734$ & & $\begin{array}{l}\text { (Temendo os significados } \\
\text { do prodígio das serpentes) } \\
\text { Enéias e seus seguidores } \\
\text { fogem para o monte Ida. }\end{array}$ \\
\hline $\begin{array}{l}\text { Desaparecimento de } \\
\text { Creúsa; seu fantasma } \\
\text { revela o futuro }\end{array}$ & 735-794 & & \\
\hline $\begin{array}{l}\text { Finda o dia, caminham; } \\
\text { chegam ao Ida ao } \\
\text { amanhecer }\end{array}$ & 795-804 & & \\
\hline
\end{tabular}

Esse cotejo revela que a recriação do saque de Tróia empreendida no canto II da Eneida evoca e conjuga os referidos épicos do ciclo troiano. A estrutura desse canto segue mais de perto a do Saque de Ílion: principiam no mesmo ponto da saga, a descoberta do cavalo, e apresentam uma coincidência de episódios mais constante. Contudo, na ausência da versão do Saque de Ílion utilizada por Virgílio, não se pode afirmar que esse poema constitua o modelo estrutural do canto. Percebe-se ainda que os episódios desprovidos de correspondência nos épicos do ciclo troiano são aqueles mais particularmente atrelados a Enéias, substancializadores do diferencial maior da recriação de Virgílio. Esse aspecto tornase mais eloqüente ao considerarmos uma tripartição do canto ${ }^{242}$ : a primeira parte (v. 13-267) abraça a descoberta do cavalo, a ação de Sínon, a de Laocoonte, a entrada do cavalo em Tróia,

${ }^{242}$ Cf. AUSTIN, 1966, p. xi. 
a chegada da noite, a saída dos guerreiros do cavalo e o ingresso dos demais gregos na cidade; a segunda (v. 268-558), o sonho com Heitor, a aristia de Corebo; o ataque ao palácio e a morte de Príamo; a terceira (v. 559-804), o episódio de Helena, o encontro com Vênus, prodígios na casa de Anquises, o desaparecimento de Creúsa e a partida para o monte Ida ${ }^{243}$. Esse conspecto denuncia que a evocação dos épicos do ciclo troiano ocorre essencialmente nos dois terços iniciais e que o terço final trata de Enéias em particular ${ }^{244}$ - abrindo a terceira parte, o verso 559 atesta essa mudança de perspectiva: At me tum primum saeuos circumstetit horror.

Ao compor sua versão do saque de Tróia, Virgílio evoca e manipula os poemas do ciclo troiano que abordam essa temática, pautando-se para tanto nas necessidades e intenções de seu poema. Com a finalidade de conhecer melhor essa composição, discutem-se a seguir alguns de seus episódios.

\section{III.2.1 - A deliberação e a entrada do cavalo em Tróia}

A Eneida retoma a deliberação com três posicionamentos (patentes na Odisséia e no Saque de Ílion), mas situa o debate no lugar onde o cavalo de madeira é encontrado (fato que a aproximaria da Pequena Ilíada).

Decidida a preservação do cavalo, os troianos conduzem-no à cidade; todavia, para o ingresso do gigantesco animal, precisam demolir uma parte da muralha (Diuidimus muros, v. 234). No estudo da Pequena Ilíada empreendido no capítulo I, essa demolição e prováveis significados mágico-religiosos desse episódio foram apreciados; na trilha desse épico, a Eneida explora a demolição do muro e valoriza tais significados (v. 234-245). Um trecho do discurso de Sínon (II, v. 185-187) deixa claro que o cavalo foi conscientemente concebido bastante alto a fim de não poder penetrar em Tróia pelas portas ou mesmo pelos muros; e a

\footnotetext{
${ }^{243}$ Harrison (1980) defende a existência de uma conexão bem articulada entre os três primeiros cantos da Eneida fundamentando-se no princípio de que a narrativa desenvolvida por Enéias nos cantos II e III seria uma resposta direta ao pedido que a rainha de Cartago the faz no final do canto I (v. 753-755): insidias Danaum corresponderia ao canto II e erroresque tuos ao canto III. Essa coerente análise, no entanto, deixa de lado um item da solicitação de Dido: casus tuorum. Acatando a interpretação de Harrison, é possível conceber que a expressão casus tuorum também se refira ao canto II e ainda aventar sentidos mais específicos para o genitivo tиorum. Lendo-se em tuorum não apenas "dos teus concidadãos" mas também "dos teus familiares", descerra-se a seguinte equivalência: insidias Danaum corresponderia à primeira parte do canto e casus tuorum à segunda ("dos teus concidadãos") e à terceira ("dos teus familiares", até o verso 794).

${ }^{244}$ Nessa passagem, Enéias trava contato com seus familiares, um a um, e a ordem em que se apresentam parece respeitar uma hierarquia ditada pela pietas e pela sociedade: inicialmente encontra uma divindade, sua mãe (v. 588-633), depois o pai (v. 634-672), em seguida a esposa e o filho, juntos (v. 673-686).
} 
Eneida evidencia o ingresso do cavalo por uma porta: Quater ipso in limine portae (v. 242). No comentário a esse verso, Sérvio admite a demolição do limiar superior da porta (pars superior diruta est) e, no comentário ao verso 241 (mencionado no estudo da Pequena Ilíada), informa tratar-se da porta Céia (porta Scaea), sítio do sepulcro de Laomendonte - a forte proteção que esse local sagrado oferecia a Tróia explicaria a dificuldade para fazer o cavalo de madeira franqueá-lo, daí as significativas quatro paradas (v. 242-245) ${ }^{245}$. Com tais relevos, o tratamento concedido pela Eneida a esse episódio sabe à trama e ao provável universo mágico-religioso da Pequena Ilíada.

Dessa forma, cumpre-se o terceiro fatum divulgado por Plauto na peça Bacchides (v. 953-955): a destruição do limiar superior de uma porta frígia (para romper o círculo divino erguido por Apolo e Netuno $)^{246}$. Com esse evento, consumam-se na Eneida os três fata indicados por Plauto, uma vez que o roubo do paládio é relatado por Sínon (II, v. 162-194) e a morte de Troilo delineia-se em uma das pinturas do templo de Juno.

\section{III.2.2 - Sínon}

Sínon não aparece em Homero. Com base na reconstituição efetuada no capítulo primeiro, a versão da Eneida para esse episódio assemelha-se mais à da Pequena Ilíada, pois a reconstituição do Saque de Ílion sugere a entrada desse grego em Tróia às escondidas. Essa idéia reforça-se quando o próprio Sínon evoca outro episódio da Pequena Ilíada, o roubo do paládio.

Sófocles escreveu uma peça intitulada Sínon, cujos fragmentos (LLOYD-JONES, 1996, p. 274-275) não permitem saber se dela Virgílio se serviu. Contudo, Paratore (ad II, v. 58) defende a possibilidade de o poeta ter usado essa peça nesse episódio, sobretudo para a confecção do discurso de Sínon ${ }^{247}$.

\footnotetext{
${ }^{245}$ Aprofundam essas questões McCartney (1925), Knight (1930, 1931 e 1933) e Duckworth (1944).

246 tertium, cum portae Phrygiae limen superum scinderetur (v. 955) - texto comentado no exame da Pequena Ilíada (capítulo I) e da imagem V (capítulo II.1).

${ }^{247}$ Sutton (1984, p. 124-125) discute a hipótese de essa tragédia ter sido o modelo de uma peça de Lívio Andronico e de outra de Névio, ambas intituladas Equos Troianus. A veracidade de tal hipótese acrescentaria um possível modelo, agora em universo romano, à abordagem de Sínon na Eneida.
} 


\section{III.2.3 - Laocoonte e a permanência de Enéias em Tróia durante o saque}

No Saque de Ílion, o episódio da morte de Laocoonte fornece indícios de ter sido um sinal enviado por Apolo a Enéias; no que tange à participação do sacerdote no episódio da deliberação a respeito do cavalo, ainda que provável, os fragmentos e testemunhos disponíveis desse épico não nos permitem assegurá-la. Na Eneida, a morte de Laocoonte difere da apresentada no Saque de Ílion e desempenha um papel determinante na deliberação. Segundo Sérvio (ad II, v. 201), a versão de Virgílio encontraria correspondência na seguinte narrativa de Euforião: o sacerdote de Netuno foi lapidado por não ter impedido com sacrifícios a chegada dos gregos; em seguida, com a retirada dos inimigos, desejosos de sacrificar a Netuno, os troianos atribuíram, por meio de um sorteio, tal missão a Laocoonte, sacerdote de Apolo Timbreu; porém Laocoonte havia cometido ocultamente um sacrilégio, unindo-se a Antíope, sua esposa, ante o simulacro de Apolo; para puni-lo por tal profanação, o deus enviou duas serpentes, as quais mataram o sacerdote e os filhos deste ${ }^{248}$. Sérvio estima ainda que os troianos interpretem esse prodígio de forma equivocada na Eneida por ignorarem o sacrilégio de Laocoonte.

Paratore (ad II, v. 41) acredita que a Eneida de fato siga essa narrativa de Euforião. Austin (ad II, v. 199-227), por sua vez, supõe que as serpentes sejam enviadas por Minerva (a cujo templo se dirigem depois de liquidar suas vítimas ${ }^{249}$ ) e ainda que Virgílio ignorasse a alegoria desse episódio expressa no Saque de Ílion - essa opinião apóia-se, sobretudo, no fato de Enéias permanecer em Tróia durante o saque, até o incêndio da cidade; pouco depois ( $a d \mathrm{v}$. 234), reiterando sua suposição, ressalta o fato de Enéias incluir-se entre os troianos iludidos, ao passo que no Saque de Ílion o herói aparentemente compreendia o sinal de Apolo e em conseqüência deixava a cidade antes do saque.

A versão de Virgílio para a morte de Laocoonte aproxima-se da atribuída a Euforião; contudo, nenhuma alusão é feita a Apolo no episódio, e a vingança desse deus não teria funcionalidade na Eneida. Por outro lado, Minerva participa integralmente do episódio: Sínon a evoca e lhe atribui a oferenda; para o templo dela as serpentes vão depois de cumprirem sua missão - e mais tarde Vênus mostra a Enéias a ação de Minerva no excídio da cidade. Logo,

\footnotetext{
${ }^{248}$ Higino (Fáb., 135) também mostra Laocoonte, sacerdote de Apolo, executado com seus dois filhos pelas serpentes enviadas por essa divindade; seu crime fora ter casado e tido filhos contra a vontade do deus.

${ }^{249}$ Quanto à divindade responsável pelas serpentes, Gransden $(1985$, p. 66) prefere a cautela, afirmando que o texto não possibilita uma posição segura.
} 
Austin estaria correto quanto ao deus responsável pelas serpentes: seguindo os indícios do texto, as serpentes consistiriam em uma ação de Minerva para arrematar a ação de Sínon e eliminar um obstáculo.

No tocante à significação alegórica do episódio, é improvável que Virgílio a ignorasse; talvez não a tenha explorado por ser, em princípio, incongruente com a versão adotada, arraigada na permanência de Enéias em Tróia durante o saque. Na verdade, para a trama da Eneida, é essencial a participação de Enéias em episódios do saque; Gransden (1985, p. 67) a justifica de forma simples e eficaz ao afirmar que o herói precisa ser a testemunha ocular através da qual o narrador pode revelar a Dido e ao leitor uma visão incisiva e incontestável do aniquilamento da cidade. Além disso, essa versão exime o guerreiro de qualquer censura por traição ou covardia.

Virgílio não inova ao protelar a saída de Enéias de Tróia, antes se serve de uma versão conhecida ao menos desde o século V a. C.: segundo Dionísio de Halicarnasso (Ant. Rom., I, 46, 1-4), o historiador Helânico de Lesbos (V a. C.) relatava na obra Troica que Enéias teria defendido a cidade por muito tempo durante o assalto, decidindo-se a partir para o monte Ida somente quando Neoptólemo e seus soldados conseguiram assenhorear-se de uma parte da acrópole.

Ao desvincular da morte de Laocoonte a saída de Enéias da Tróia, Virgílio toca um elemento importante do ciclo troiano: a querela entre os dois ramos descendentes de Dárdano. Em sua recriação do saque da cidade, o ramo de Ilo também é exterminado, e o de Assáraco sobrevive e um dia reina sobre homens (isso em acordo com a alegoria da morte de Laocoonte); todavia, não há ressentimento entre Enéias e Príamo, não há por que abandonar a cidade sem defendê-la até o último instante; ao contrário, o relato feito pelo herói enaltece a figura do monarca troiano e a reveste de efeito patético; e a transmissão de poder de um ramo para o outro ocorre de forma amistosa (no episódio do sonho com o fantasma de Heitor) ${ }^{250}$.

\section{III.2.4 - Enéias}

O tratamento concedido à figura de Enéias no saque da cidade constitui o grande diferencial da Eneida em relação aos épicos do ciclo troiano que abordam essa temática: aqui os fatos são vistos da perspectiva dele, em função dele e narrados por ele. Delineia-se um

\footnotetext{
${ }^{250}$ Esses aspectos são comentados no capítulo II: o respeito por Príamo no estudo da disposição das pinturas, e a transmissão de poder na análise das pinturas IV, VIII, IX e X e também no estudo da disposição das pinturas.
} 
novo perfil para o herói. Sua participação especial no canto II principia no episódio do sonho com Heitor (v. 268-297). O fantasma do filho de Príamo aparece e profere as seguintes palavras (v. 289-295):

\author{
"Heu fuge, nate dea, teque his" ait "eripe flammis. \\ Hostis habet muros, ruit alto a culmine Troia. \\ Sat patriae Priamoque datum: si Pergama dextra \\ defendi possent, etiam hac defensa fuissent. \\ Sacra suosque tibi commendat Troia penatis; \\ hos cape fatorum comites, his moenia quaere \\ magna, pererrato statues quae denique ponto." \\ Ah! Foge, filho de uma deusa, evita as chamas. \\ Hostes detêm os muros, Tróia cai do cimo. \\ Bastante à pátria e a Príamo se deu: se a Pérgamo \\ valesse a destra, a minha tê-la-ia salvo. \\ Tróia te outorga os sacros bens e seus penates; \\ faze-os sócios de fado, busca-lhes muralhas, \\ magnas, que ao fim, transposto o mar, tu hás de erguer.
}

Não há mais o que fazer para salvar Tróia, Enéias poderia tê-la abandonado logo após receber essas instruções de Heitor. Trata-se, no entanto, de um sonho, e Enéias precisa comprovar a veracidade do que acaba de ouvir; ademais, não lhe passa pelo espírito partir sem lutar, sem tentar socorrer a cidade; por conseguinte, arma-se e vai ao encontro dos inimigos. Desse momento até sua fuga, ocorrem eventos significativos para a sequiência do poema e materializadores das palavras de Heitor - as quais, por essa razão, funcionam como uma proposição para o restante do canto.

Uma parte do sonho (Sacra suosque tibi commendat Troia penatis) concretiza-se pouco depois de Enéias despertar (v. 318-369): a sua casa chega Panto, o sacerdote de Apolo na cidadela, conduzindo objetos sagrados, os penates de Tróia e uma criança (sacra manu uictosque deos ${ }^{251}$, v. 320). As palavras de Panto (v. 324-335) praticamente repetem as de Heitor quanto ao fim inelutável de Tróia. Gransden (1985, p. 68) supõe aqui a sugestão de uma investidura de Enéias como sacerdote de Apolo, sucessor de Panto, fato que ligaria o herói a Augusto, investido do mesmo sacerdócio; para confirmar essa hipótese, ressalta que a cena do aparecimento de Panto prefigura de forma clara a da fuga de Enéias, levando os objetos sagrados e uma criança.

\footnotetext{
${ }^{251}$ Quanto à equivalência entre uictos deos e penates, Sérvio ( $a d$ II, v. 320) acredita que Panto de fato porte os sacra e os penates e atrela esse verso às palavras de Heitor. Além disso, os penates conduzidos por Enéias à Itália recebem o adjetivo uictus no canto I (v. 67: Ilium in Italiam portans uictosque penatis) e no VIII (v. 10-12: Latio consistere Teucros/ Aduectum Aenean classi uictosque penatis / inferre [...].
} 
Esse sonho atua como o sinal de Apolo do Saque de Ílion: ao invés de uma alegoria com as serpentes, o fantasma de Heitor aparece diretamente e atribui uma missão a Enéias ${ }^{252}$. Vem à tona com isso o tema da querela entre os ramos descendentes de Dárdano, mais especificamente a idéia da destruição do ramo de Ilo e do conseqüente assumir do poder pelo de Assáraco: Virgílio faz o ramo regente (em vias de desaparecimento) passar amistosamente o poder para o outro. Essa transmissão de função justifica a saída de Enéias e lhe concede a missão de governar os troianos sobreviventes; mas o guerreiro reluta e prossegue em sua tentativa de salvar a cidade - um esforço vão que se reporta às seguintes palavras de Heitor: $s i$ Pergama dextra / defendi possent, etiam hac defensa fuissent. Nessa campanha, após a morte de Panto, Enéias justifica sua conduta (v. 431-434):

\footnotetext{
Iliaci cineres et flamma extrema meorum, testor in occasu uestro nec tela nec ullas uitauisse uices Danaum et, si fata fuissent ut caderem, meruisse manu.

Cinzas de Tróia e chama última dos meus, Testemunhais que, em vosso ocaso, nem dos dardos, nem do embate com dânaos me esquivei; se fosse meu fado a queda, em luta obtê-lo-ia.
}

Tais versos, um juramento, elevam-se contra acusações de traição ou covardia que pesam sobre o Enéias anterior à Eneida e participam diretamente da reformulação da lenda desse herói urdida por Virgílio. Essa relutância somente se desfaz quando Vênus lhe aparece e revela não haver realmente salvação para Tróia; ao "abrir os olhos dele", a deusa revigora a exortação para a fuga proferida antes por Heitor: Eripe, nate, fugam finemque impone labori (v. 619). E ele enfim constata a queda da cidade: Tum uero omne mihi uisum considere in ignis / Ilium et ex imo uerti Neptunia Troia (v. 624-625).

Enéias então segue para a casa de Anquises, na ânsia de esquivar sua família da ruína de Tróia. E nesse momento é Anquises quem se mostra relutante; a teimosia do velho apenas se aplaca quando dois augúrios ${ }^{253}$ revelam ser a vontade dos deuses ${ }^{254}$ que eles deixem a

\footnotetext{
${ }^{252}$ O início desse episódio, notadamente o verso 281, evoca um trecho da peça Alexander de Ênio (Warmington, 1956, fr. 76-79), na qual Heitor aparecia em sonho para Cassandra.

${ }^{253}$ Austin (ad II, v. 691) explica os dois auguria: o primeiro, o fogo na cabeça de Ascânio, configuraria um augurium oblatiuum (enviado pelos deuses sem uma solicitação); o segundo, o trovão de Júpiter, um augurium impetratiuum (enviado pelos deuses em resposta a uma solicitação). E Sérvio (ad II, v. 691) informa que a necessidade de um augúrio confirmativo corresponde a um costume romano.

${ }^{254}$ Austin (1966, p. xxi) salienta o contraste entre a inclemência de alguns deuses contra Tróia no instante da epifania de Vênus e pouco depois a ajuda e os sinais que o plano divino fornece à família de Enéias para que saia
} 
cidade agonizante. Enfim decididos a partir, Enéias pede ao pai que apanhe os sacra uictosque deos que estavam em poder de Panto (e que haviam ficado na casa de Anquises), a fim de levá-los ao exílio: Tu, genitor, cape sacra manu patriosque penatis (v. 717).

Comprovando a subjacência do sonho com o fantasma de Heitor, esse evento na casa de Anquises concretiza a segunda parte destas palavras: Sacra suosque tibi commendat Troia penatis; / hos cape fatorum comites, his moenia quaere / magna.

A Enéias compete a missão prefigurada por Posídon no cano XX da Ilíada (v. 307308)... A Virgílio, a missão de reformular a lenda desse herói, de redefinir seu papel na saga troiana.

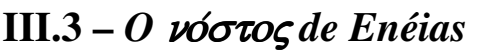

$\mathrm{Na}$ trama do ciclo troiano, dá continuidade ao saque a temática dos vóotor dos guerreiros, ocupando os épicos Retornos e Odisséia. Na Eneida, essa seqüência se reproduz: depois do canto II, a viagem realizada por Enéias e seus seguidores desde Antandro, na região

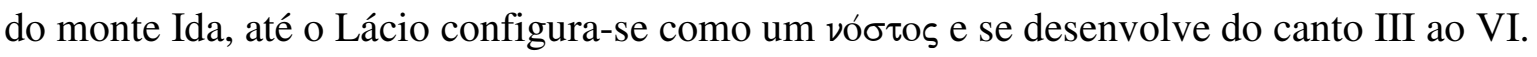

\section{III.3.1 - Canto III}

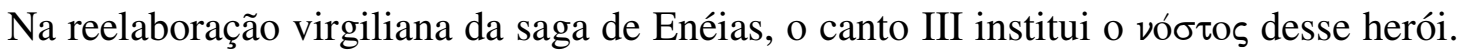
De Antandro até Drépano, na Sicília, Enéias e os troianos que o acompanham vivenciam muitas aventuras. Para compô-las, além de recorrer a poemas gregos, Virgílio precisou lidar com uma grande quantidade de histórias ligadas a essa migração (comumente denominadas "lenda de Enéias") e com abordagens anteriores do assunto feitas por autores latinos, como Névio (c.270-201 a. C.) no poema Bellum Poenicum ${ }^{255}$. Uma fonte fecunda para essas histórias é o livro I da obra Antiguidades Romanas de Dionísio de Halicarnasso, composta entre 30 e 7 a. C. (Ant. Rom., I, 3, 7), ou seja, na mesma época em que Virgílio tecia a Eneida. Em meio à massa de textos componentes da lenda de Enéias, muitas vezes conflitantes, há um ponto

\footnotetext{
de Tróia em segurança. Longe de ser incoerente, esse contraste reverbera bem a oposição entre os destinos dos ramos de Dárdano.

${ }^{255}$ Os principal estudo dessas histórias é a obra Les origines de la Légende Troyenne de Rome, de Jacques Perret (1942); outro grande trabalho é o livro Aeneas, Sicily and Rome (1969), de G. Karl Galinsky, que revisa certos aspectos da obra de Perret; vale ainda citar a apreciação de Heinze em seu Virgil's Epic Technique (capítulo "The Wanderings of Aeneas", 2004, p. 68-94).
} 
consensual: a importância da profecia de Posídon no canto XX da Ilíada (v. 307-308), uma verdadeira nascente dessa lenda.

$\mathrm{Na}$ viagem dos troianos, há os seguintes episódios: vão inicialmente à Trácia, depois a Delos, a Creta, às Estrófades, ao Epiro, onde aportam em Ácio e em Butroto; na passagem do Epiro para a Itália, aportam em um local incerto onde há um templum Mineruae; da costa da Sicília, divisam Cila e Caribde; na Sicília, aportam nas praias dos Ciclopes, de onde resgatam Aquemênides, depois em Drépano, onde Anquises falece.

Como atribuir unidade a tantos episódios, a tantas paragens? Heinze (2004, p. 68-69) reconhece nos relatos de Dionísio de Halicarnasso (I, 49-55) duas motivações maiores para as paradas efetuadas pela frota de Enéias: a renovação de velhos laços de amizade, de alianças, e o efeito de forças naturais, como ventos e tempestades. Apesar disso, não haveria um fator decisivo, capaz de conceder unidade às aventuras, o único ponto em comum seria a direção da viagem. Em vista dessa dificuldade, julga que Virgílio precisou, antes de tudo, descobrir um critério de unidade para orientar a seleção e a composição dos episódios; e o critério encontrado seria o da revelação do destino da viagem, feita de forma gradual - uma confirmação do emprego desse critério emerge no final do canto, nos versos 716-717: Sic pater Aeneas intentis omnibus unus / fata renarrabat diuom cursusque docebat.

Desenvolvendo essa idéia, Robert B. Lloyd (1957b, p. 388) assinala a existência de dois princípios de organização desse critério: uma explicação das origens de instituições romanas $^{256}$ e uma alusão ao futuro através de presságios, profecias, oráculos... Em outro artigo, Lloyd (1957a, p. 137) investiga detalhadamente os seguintes veículos de revelações: o "fantasma" de Polidoro na Trácia, o oráculo de Apolo em Delos, o sonho com os penates em Creta, a maldição da harpia Celeno nas Estrófades, as profecias de Heleno em Butroto e o presságio dos quatro cavalos brancos na passagem do Epiro à Itália. Além de indicar a meta, a Itália, tais veículos dizem como Enéias deve proceder para alcançá-la e antecipam alguns perigos da jornada. Lloyd (1957a, p. 142) destaca ainda um pormenor significativo: a profecia de Heleno é a mais longa e importante e ocorre intencionalmente no centro do canto.

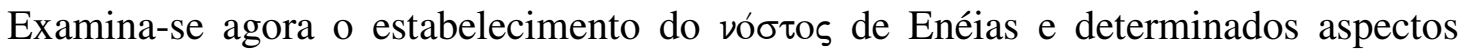
relevantes para discussões tecidas neste estudo.

\footnotetext{
${ }^{256}$ Esse procedimento etiológico de fundo histórico já havia sido empregado no mundo romano, notadamente por Catão (234-149 a. C.) na obra Origines. Também inegável é a influência do poema Aĩtía, de Calímaco (c.305240 a. C.).
} 


\section{III.3.1.1 - O destino distinto dos ramos de Dárdano e a fuga para o monte Ida}

Os oito versos iniciais do canto III já se proclamam um terreno fértil, suscitando o exame de duas questões relevantes para esta investigação: a distinção entre os ramos de Ilo e Assáraco (Priamique euertere gentem, v. 1) e a fuga para o monte Ida, onde os troianos liderados por Enéias constroem uma frota e de onde partem rumo ao Ocidente (classemque sub ipsa / Antandro et Phrygiae molimur montibus Idae, v.5-6).

Considerando-se a carga semântica do termo gens na cultura romana, a expressão Priami gentem reportar-se-ia com mais propriedade à estirpe de Príamo; assim sendo, mencionaria o fim da regência desse ramo, o fim da Tróia de Príamo.

No verso 248 desse canto, a distinção entre os ramos faz-se mais forte ao som do termo Laomedontiadae, empregado pela harpia Celeno - no dizer de Horsfall (ad III, v. 248), uma alusão ao "pecado original" troiano.

Nessa linha de raciocínio, Horsfall (ad III, v. 339) ressalta que as perguntas de Andrômaca a respeito de Ascânio (v. 339-343) trazem à lembrança o fato de Príamo, Heitor e Astíanax estarem mortos, enquanto Anquises, Enéias e Ascânio estão vivos e em Butroto. E esse paralelo entre os dois ramos tem seus contornos fortalecidos pouco depois, quando Andrômaca compara Ascânio com Astíanax, o filho morto (III, v. 486-491).

Seja permitido nesse momento um olhar sobre um dado curioso e pertinente a essa questão: na Eneida (III, v. 328-332), relata-se a morte de Neoptólemo de forma semelhante à de Príamo, ao pé de um altar. Outro ciclo se fecha: Aquiles e seu filho liquidaram Heitor e Príamo $^{257}$, pondo fim ao governo desse ramo; agora morre o filho de Aquiles, finda a linhagem desse herói.

A fuga de Enéias para o monte Ida também toma parte no tema da sorte distinta dos descendentes de Dárdano.

Anderson (1997, p. 73-74) recorda uma informação dada por Enéias no canto XX da Ilíada (v. 215-218): Dárdano habitava o Ida antes de Tróia existir. Essa cidade foi de fato fundada por Ilo $^{258}$ (daí o nome Ílion) e caiu em desgraça a partir de Laomedonte, o qual pediu a Apolo e a Posídon que construíssem os muros dela (Ilíada, VII, v. 452-453). Tróia é, pois, condenada juntamente com a descendência de seu fundador.

\footnotetext{
${ }^{257}$ E Neoptólemo é provavelmente o responsável pela morte de Astíanax na Pequena Ilíada.

${ }^{258}$ Fato relatado por Apolodoro (III, 12, 3).
} 
Enquanto Tróia identifica-se com a família de Príamo, o monte Ida seria a casa da família de Enéias. Nesse local, Vênus seduziu Anquises, e Enéias foi concebido (Teogonia, v. 1008-1010 e Ilíada, II, v. 821); aí as ninfas cuidaram de Enéias (Hino Hom. a Afrodite, v. 256-273; aí, segundo a Ilíada (XX, v. 89-91, v. 188-190) e os Cantos Cíprios, Enéias tangia seu gado quando encontrou Aquiles ${ }^{259}$.

Anderson (1997, p. 74) reconhece na polaridade Tróia-Ida um reflexo da polaridade ramo de Ilo-ramo de Assáraco. Em verdade, a queda de Tróia não é propriamente a da cidade de Enéias, mas da de Príamo. Por conseguinte, quando Enéias foge para o Ida, retorna para a fonte da família de Dárdano e para seu verdadeiro lar, dando andamento à profecia de Posídon (Ilíada, XX, v. 307-308) também de um ponto de vista geográfico.

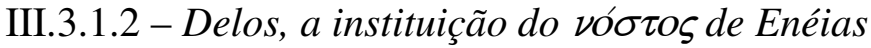

Em Delos, Enéias interroga o oráculo de Apolo a respeito do destino de sua viagem. Eis a resposta do deus (v. 94-98):

\section{Dardanidae duri, quae uos a stirpe parentum prima tulit tellus, eadem uos ubere laeto accipiet reduces. Antiquam exquirite matrem. Hic domus Aeneae cunctis dominabitur oris et nati natorum et qui nascentur ab illis.}

\author{
Rijos dardânidas, de vossos pais a terra \\ primeira a vós acolherá com seio fértil \\ neste retorno. Procurai a mãe antiga. \\ Lá, terras unas domará o lar de Enéias, \\ e os filhos de seus filhos, e os que deles nascerem.
}

Nesses versos, Apolo define os troianos como reduces e os aconselha a procurar a antiga mãe. Caracteriza-se a viagem como um vó $\sigma \varsigma^{260}$.

E, como indicado no capítulo II (na análise da imagem do reconhecimento de Enéias), os versos 93 e 94 evocam (e praticamente traduzem) os verso 307 e 308 do canto XX da Ilíada, ou seja, a profecia de Posídon. Com esse procedimento, Virgílio vincula textualmente

\footnotetext{
${ }^{259}$ Debiasi (2004, p. 142-143) comenta essa questão.

${ }^{260}$ Horsfall (ad III, v. 94) cita a possível existência de um "Retorno dos Dardânios" conhecido no mundo romano. Sérvio (ad III, v. 148) reporta essa indicação a Varrão; mas não se sabe em verdade se Varrão escreveu algo sobre o assunto, a fonte dessa lenda permanece desconhecida. Um "Retorno dos Dardânios" poderia ser uma lenda comum no mundo romano, inspirada pela partida de Dárdano da Itália (da Etrúria) para a Ásia. Ver ainda Horsfall (ad VII, v. 195 e v. 206-211).
} 


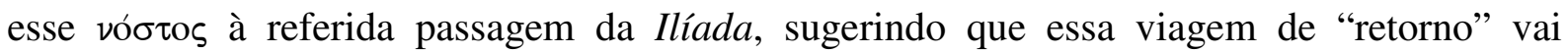
cumprir as palavras de Posídon.

Estrabão (Geografia, XIII, 1, 53) apresenta uma variante do verso 307: Aìvíao ßín

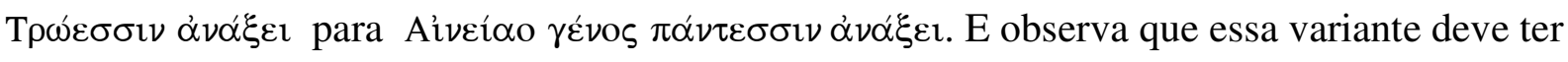
por objetivo justificar uma viagem de Enéias à Itália, com $\pi \alpha \hat{\imath} \delta \varepsilon \varsigma \pi \alpha i \delta \omega \nu$ do verso 308 significando "os romanos". Smith (1981, p. 44, n. 49) acredita que essa variante seja a base do verso 93 desse canto da Eneida.

Destarte, a passagem por Delos assume papéis fundamentais: evidencia uma relação

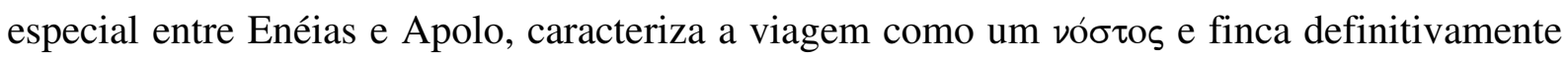
no canto XX da Ilíada as raízes da reelaboração da lenda de Enéias e dos liames entre a Eneida e o ciclo troiano.

\section{III.3.1.3 - Em Creta, a Eneida encontra os Retornos}

A passagem por Creta não integrava a lenda de Enéias anterior à Eneida. Por que Virgílio teria levado o herói a essa ilha?

Horsfall (ad III, v. 121-191) fornece um argumento convincente para essa inovação. Uma passagem por Creta seria essencial para o projeto de Virgílio referente à idéia de Antiquam matrem: as duas origens dos troianos deveriam figurar no poema, Teucro de Creta $\mathrm{e}$ Dárdano da Itália; com a interdição divina de Creta, a Itália torna-se obrigatoriamente o destino indicado pelo oráculo de Apolo.

Nesse episódio aparecem versos evocadores do poema Retornos (v. 121-123):

\footnotetext{
Fama uolat pulsum regnis cessisse paternis Idomenea ducem, desertaque litora Cretae, hoste uacare domum sedesque astare relictas.

A Fama voa... expulso dos paternos reinos Idomeneu, o chefe, e em Creta as praias ermas, sem inimigo a terra, e as casas relegadas.
}

No início deste capítulo, comenta-se um discurso em que Diomedes (XI, v. 255-277)

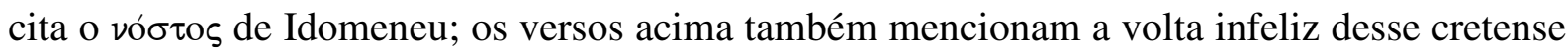
e aludem à vingança engendrada por Náuplio em razão da morte de Palamedes. No estudo dos Retornos, viu-se que Náuplio instigou o adultério de Meda, esposa de Idomeneu, com Leuco. 
E Apolodoro (Epítome, 6, 7-11) relata que Leuco matou Meda e a filha desta, Clisitera, conquistou dez cidades cretenses e baniu Idomeneu da ilha quando este regressou.

Além de essencial para o enredo da Eneida, definindo a Itália como destino, a passagem por Creta estabelece um contato com os Retornos. Uma vez instituído o vó

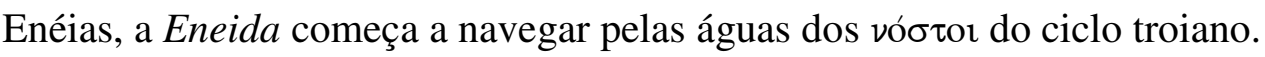

\section{III.3.1.4 - Mergulho em águas da Odisséia}

Ao deixar Creta, a frota de Enéias é açoitada por uma tempestade, que a conduz às Estrófades (v. 192-208). O paradigma desse episódio vem do canto XII da Odisséia: após devorarem os bois de Hélio, Odisseu e seus homens deixam a ilha do Sol, na Sicília; no mar, são castigados por uma tempestade (v. 403-430), que destrói a frota e acaba enviando Odisseu sozinho à Ogígia, ilha de Calipso. Levando em conta a ordem cronológica dos acontecimentos, essa tempestade marca o ponto a partir do qual a Odisséia funciona como

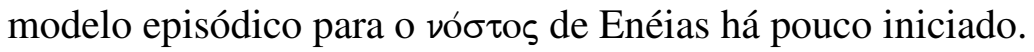

Comentando essa tempestade, Horsfall ( $a d$ III, v. 192-208) desenvolve a idéia segundo a qual Virgílio teria reelaborado por inversão uma sequiência homérica: no canto XII da Odisséia, ocorre a advertência de Circe (XII, v. 127-141), depois o massacre do rebanho de Hélio (XII, v. 339-365) e enfim a tempestade; na Eneida, primeiramente a tempestade (v. 192-208), depois o massacre do rebanho das harpias (v. 219-224) e enfim a profecia de Celeno (v. 245-257).

\section{III.3.1.5 - As harpias}

As harpias são sugeridas à Eneida pelo canto II das Argonáuticas de Apolônio de Rodes. Em decorrência, poder-se-ia supor que este poema tivesse fornecido o modelo episódico para aquele. Horsfall (ad III, v. 209-269), porém, desfaz essa suposição: o modelo proviria essencialmente do canto XII da Odisséia, com a nítida retomada do ataque ao rebanho de Hélio. Pouco depois, seguindo a idéia de que Virgílio opera aqui a referida inversão de episódios desse poema homérico, Horsfall (ad III, v. 247-257) liga a profecia de Celeno à advertência de Circe: o aviso da fome corresponderia ao da perda dos barcos e dos companheiros de Odisseu. 
O vaticínio de Celeno sobre a fome que fará os troianos "comerem as mesas" (III, v. 255-257) pertence à lenda de Enéias anterior à Eneida e representa um elemento fundamental para a descoberta do destino da viagem: Dionísio de Halicarnasso (I, 55, 4) relata que um oráculo em Dodona anuncia aos troianos que reconhecerão o final da jornada, o local onde devem se estabelecer quando "comerem as mesas".

Assim, Virgílio preservou a importância e a função desse presságio, mas o transferiu para as Estrófades. Esse procedimento denota grande coerência na intriga de seu épico: nesse episódio, a rota correta para a antiqua mater se configura de fato ${ }^{261}$, e surge uma indicação para o reconhecimento da "terra prometida".

No tocante à relação com o ciclo troiano, após evocar os Retornos em Creta, a Eneida segue sendas da Odisséia com a tempestade e com esse episódio nas Estrófades.

\section{III.3.1.6 - Em Butroto, a Eneida reencontra os Retornos}

A parada em Dodona e as revelações do oráculo nesse local, mencionadas por Dionísio de Halicarnasso (I, 55, 4), são incorporadas ao episódio de Butroto (v. 294-505), com as significativas revelações de Heleno.

Esse episódio evoca os Retornos: de acordo com o estudo e a reconstituição empreendidos no primeiro capítulo, Heleno e Andrômaca acompanham Neoptólemo em sua volta de Tróia; e o termo dessa jornada se dá no Epiro, na terra dos molossos, perto de Dodona.

Um elemento significativo para a reelaboração de Virgílio e até mesmo para o enredo dos Retornos insinua-se nesse episódio. Ao chegar à cidade, Enéias encontra Andrômaca em meio a um ritual fúnebre dedicado às cinzas de Heitor. Ao ver Enéias, espantada, pergunta se o herói está vivo (uiuisne?, v. 312) ou, caso esteja morto, onde se encontra Heitor (aut, si lux alma recessit, / Hector ubi est?, v. 312-313). Realizando ritos funéreos, Andrômaca pensa que Enéias surge do mundo dos mortos, como as almas afluem para junto de Odisseu no canto XI da Odisséia; com isso, o episódio no Epiro alude a uma nekyia, e é Andrômaca quem preside a evocação dos mortos: Heitor logo no início, depois Polixena (v. 321-324), Neoptólemo (v. 330-333), Creúsa (v. 341) e Astíanax (v. 488-491).

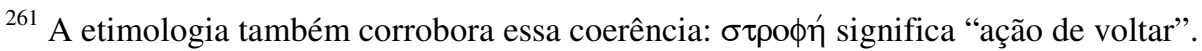


Essa alusão reforça-se ao se retomar a teoria da inversão defendida por Horsfall e há pouco citada. Dando continuidade à estratégia de inversão, a Eneida deixaria o canto XII da Odisséia ao sair de Creta e, ao entrar no Epiro, ingressaria no XI: as profecias de Heleno entram em paralelo com as de Tirésias (XI, v. 100-137), e assim a nekyia da Odisséia vem à tona.

Uma nekyia também tinha lugar nos Retornos, mas não é possível dizer onde exatamente: viu-se que Davies (1989a, p. 80-81) a supõe em Cólofon, ligando-a ao local da morte de Tirésias, e que Severyns (1928b, p. 385-386) e Burgess (2001, p. 142-143) a situam em Maronéia, ligando-a ao encontro de Neoptólemo com Odisseu. Uma vez que esse episódio evoca de forma clara os Retornos, Virgílio também estaria aludindo à nekyia desse épico? Teria acontecido no Epiro a nekyia desse épico?

Para ampliar a ambiência dos Retornos nesse episódio, Heleno menciona cidades fundadas por guerreiros ao voltarem de Tróia: Narícia, por homens do Ájax lócrio (v. 399); Salento, por homens de Idomeneu (v. 400-401); Petília, por Filoctetes (v. 401-402).

\section{III.3.1.7 - Morte de Anquises}

Em razão dos interesses deste estudo, salienta-se apenas um dado relativo à morte de Anquises (III, v. 708-713): Kopff (1981, p. 934-935) suspeita de que esse episódio tenha sido influenciado pelo da morte de Calcante nos Retornos. Seria mais um elemento da evocação dessa epopéia nesse canto da Eneida.

Ao fim da análise de determinados pormenores desse canto, patenteia-se o fato de Virgílio ter explorado a lenda de Enéias, a temática dos retornos dos heróis que lutaram em

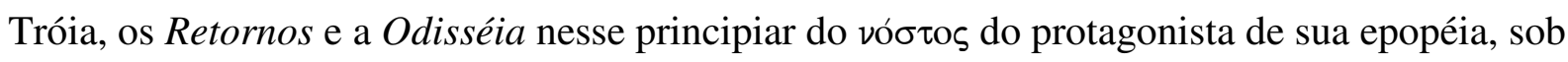
a condução e a proteção de Apolo.

\section{III.3.2 - Canto IV}

O canto IV constitui uma continuação das aventuras em Cartago, interrompidas pelo relato de Enéias; desse modo, forma uma unidade com o canto I.

Grande parte de sua organização pauta-se nos cantos V e X da Odisséia, com a seguinte correspondência de episódios: 


\begin{tabular}{|c|c|c|c|}
\hline Eneida & Conteúdo & Fonte & Conteúdo \\
\hline v. $1-172$ & $\begin{array}{l}\text { Alienação de Enéias em Cartago; } \\
\text { Dido tenta "enfeitiçar" Enéias }\end{array}$ & $\begin{array}{l}\text { Odisséia, X } \\
\text { v. } 307-468\end{array}$ & $\begin{array}{l}\text { Alienação de Odisseu e de seus homens } \\
\text { junto de Circe; Circe tenta enfeitiçar } \\
\text { Odisseu }\end{array}$ \\
\hline v. $173-264$ & $\begin{array}{l}\text { Jarbas reclama a Júpiter, que envia } \\
\text { Mercúrio a Enéias }\end{array}$ & $\begin{array}{l}\text { Odisséia, V } \\
\text { v. } 1-115\end{array}$ & $\begin{array}{l}\text { Atena pede a partida de Odisseu a Zeus, } \\
\text { que envia Hermes a Calipso }\end{array}$ \\
\hline v. $265-276$ & $\begin{array}{l}\text { Discurso de Mercúrio pedindo a } \\
\text { Enéias que reavive na mente seu } \\
\text { destino e o dos seus }\end{array}$ & $\begin{array}{l}\text { Odisséia, X } \\
\text { v. 469-477 }\end{array}$ & $\begin{array}{l}\text { Discurso de Euríloco, pedindo a Odisseu } \\
\text { que reavive na mente seu destino }\end{array}$ \\
\hline v. $277-295$ & $\begin{array}{l}\text { Enéias inicia os preparativos da fuga } \\
\text { em segredo }\end{array}$ & & \\
\hline v. $296-703$ & Desespero e morte de Dido & $\begin{array}{l}\text { Odisséia, V } \\
\text { v. 116-147 }\end{array}$ & Lamentação de Calipso \\
\hline
\end{tabular}

Essa estrutura é preenchida em especial com elementos provenientes da lenda de Enéias anterior à Eneida (possivelmente explorados por $\mathrm{Névio}^{262}$ ), do canto III das Argonáuticas de Apolônio de Rodes, da Medéia de Eurípides e do poema LXIV de Catulo.

No tocante ao modelo estrutural, aqui a Eneida continua em águas da Odisséia.

Convém relembrar a alusão à querela entre os ramos, mais precisamente à condenação do ramo de Ilo, feita nos versos 541 e 542 (nescis heu, perdita, necdum / Laomedonteae sentis periuria gentis?).

\section{III.3.3 - O canto $V$}

$\mathrm{O}$ canto V apresenta como episódios principais os jogos (v. 104-602), a queima dos barcos (v. 603-699), a fundação de Acesta (v. 700-778), o sonho de Enéias com Anquises (v. 721-745, em meio ao processo de fundação de Acesta), o diálogo entre Vênus e Netuno (v. 779-824) e a morte de Palinuro (v. 825-861).

Os jogos são imitados do canto XXIII da Ilíada (v. 226-897, a patroclia); na intriga da Eneida, ensejam a queima dos barcos: as mulheres troianas ficaram sozinhas, usufruíram de uma pausa para refletir juntas, sem o controle dos homens, estão cansadas e a Sicília lhes agrada.

\footnotetext{
${ }^{262}$ Sérvio (ad IV, v. 9): 'Anna soror' cuius filiae fuerint Anna et Dido, Naeuius dicit. Heinze (Virgil's Epic Technique, p. 95 e p. 106, n. 1) acha provável que Névio tenha retrabalhado o mito de Dido no estilo das histórias de amor helenísticas, enviando à pira funérea a mulher amada e abandonada por Enéias.
} 
A queima dos barcos, por sua vez, faz parte da lenda de Enéias anterior à Eneida. Dionísio de Halicarnasso (I, 72, 2) atribui um evento semelhante à versão de Helânico de Lesbos (séc. V a. C.) para a fundação de Roma: Rome, a troiana da qual proviria o nome do lugar, teria instigado outras troianas a queimar os barcos, forçando Enéias a ficar na região e ali fundar uma cidade ${ }^{263}$; Sérvio ( $a d \mathrm{X}$, v. 179) liga esse acontecimento à fundação de Pisa: alguns gregos que voltavam de Tróia tiveram suas naves incendiadas por cativas troianas e foram obrigados a permanecer no local, onde fundaram uma cidade, cujo governo coube a Epeu, o fabricante do cavalo de madeira.

Virgílio situou a queima dos barcos na Sicília, provavelmente seguindo variantes já existentes $^{264}$. Com isso, justificou a fundação de Acesta (futura Segesta ${ }^{265}$ ), cidade significativa para a história romana, sobretudo no contexto das guerras púnicas: Segesta foi a primeira cidade da Sicília a se aliar a Roma na luta contra Cartago ${ }^{266}$. Com esse dado histórico nas entrelinhas, o canto $\mathrm{V}$ intensifica a alusão às guerras púnicas e assim se vincula intimamente à aventura em Cartago ${ }^{267}$.

No diálogo entre Vênus e Netuno, pronunciam-se palavras significativas para questões discutidas no capítulo anterior (especialmente em II.2.1 - Parte alia). Com a finalidade de tranqüilizar Vênus quanto à sua disposição de ajudar Enéias, o deus relembra ter livrado esse herói da morte pelas mãos de Aquiles (Pelidae tunc ego forti / congressum Aenean nec dis nec uiribus aequis / nube caua rapui, v. 808-810); ou seja, Netuno relembra um episódio do canto XX da Ilíada (v. 318-343).

Antes de tudo, essas palavras reafirmam a importância desse canto da Ilíada para a intriga da Eneida. Além disso, evocam os versos 97 e 98 do canto III, enraizados nos versos 307 e 308 do canto XX da Ilíada, arautos da missão de Enéias (delegada por Posídon). Em decorrência, a presença de Netuno e suas palavras resgatam a missão de Enéias nesse momento de grande incerteza do herói e às vésperas de sua catábase. E, nesse contexto, Vênus se esforça para que essa missão se cumpra. Enfim, nesse diálogo, é possível perceber a

\footnotetext{
${ }^{263}$ Dionísio de Halicarnasso (I, 72, 3-4) cita ainda um texto de Aristóteles que relatava cativas troianas terem queimado barcos dos aqueus no Lácio, onde aportaram obrigados por uma tempestade.

${ }^{264}$ Dionísio de Halicarnasso (I, 52, 4) alude a uma versão da queima de alguns barcos da frota de Enéias na Sicília.

${ }^{265}$ Cícero (In Verrem, II, 4, 72) refere a fundação de Segesta por Enéias.

${ }^{266}$ Heinze (2004, p. 134) discute com detalhes essa questão.

${ }^{267}$ Para Perret (1952, p. 18), a história em Cartago conclui-se de fato no canto V.
} 
seguinte mensagem sublinear endereçada por Netuno a Vênus: "Não se preocupe, a característica marcante de seu filho é sempre escapar dos perigos letais!".

Dessa forma, depois da digressão por Cartago, esse canto, sem esquecer o IV, retoma o universo do III. Otis (1964, p. 272) parece estar com a razão ao reconhecer no retorno à Sicília, após "escapar” de Dido, o simbolismo de uma renovação de seus laços com Anquises, de uma retomada de consciência de sua missão do canto III.

Outra questão relevante eclode nesse diálogo: a condenação de Tróia e com ela a do ramo de Ilo. Netuno diz que, na época da guerra de Tróia, desejava destruir os muros dessa cidade perjura (uertere ab imo / structa meis manibus periurae moenia Troiae, v. 810-811).

No fim desse canto, com o elo entre a morte de Palinuro e a de Elpenor (Odisséia, X, v. 552-560) e com a contemplação do promontório das sereias (v. 862-865), a Eneida mergulha outra vez na Odisséia. Aliás, segundo Knauer (1981, p. 878), Virgílio teria transformado o final do canto X da Odisséia (v. 469-574) no final do canto V da Eneida (v. 700-871): Circe à noite revela a Odisseu (há um ano com ela) que o herói deve visitar a casa de Hades; na Eneida, Anquises aparece em sonho a Enéias (um ano depois de morrer) e pede ao filho que visite a morada de Dite (V, v. 731-733).

A configuração desse canto dificulta a determinação de seu modelo estrutural. Ainda que o episódio dos jogos seja o mais extenso, não caracteriza a Ilíada como modelo estrutural, pois constituem uma unidade (embora longa) dentro de um canto com vários episódios e os acontecimentos posteriores são mais ricos de significação ${ }^{268}$. E, ao lado dos eventos em honra de Anquises, salientam-se fatos da lenda de Enéias e mesmo da história de Roma. Quanto à Odisséia, apenas reaparece no final do canto. Em face desse quadro, conclui-se que não se pode definir um modelo estrutural para a composição do canto; por outro lado, os elementos da Odisséia aqui presentes, preparando a transição para o VI, são suficientes para assegurar que esse poema continue a desempenhar o papel de modelo estrutural do horizonte que se desenha nos cinco cantos até agora examinados.

\footnotetext{
${ }^{268}$ Otis (1964, p. 270, n. 1) afirma que os jogos não constituem o elemento fundamental do canto V. Pouco depois, pensando nas correspondências entre cantos, Otis (p. 273-274) explica a presença dos jogos, um episódio da Ilíada, em meio à parte odissíaca como um procedimento para estabelecer um paralelo com o canto IX, na parte iliádica, e assim prefigurar eventos da guerra no Lácio e as façanhas dos troianos.
} 


\section{III.3.4 - O canto VI}

O canto VI inspira-se na nekyia do canto XI da Odisséia. Todavia, à diferença de Odisseu, Enéias realiza uma verdadeira catábase; além disso, o conteúdo desses dois cantos difere bastante, no palco da catábase de Enéias, desfilam a história de Roma, idéias filosóficas e noções e religiosas.

Enéias sai desse canto VI transformado, revigorado, instruído sobre seu destino e sobre a importância de sua missão. É interessante notar que, nessa transformação, o herói lida com personagens dos cantos anteriores, enfrentando novamente suas perdas, suas dores: Palinuro (v. 337-383) dos cantos III e V, Dido (v. 450-476) dos cantos I e IV, Deífobo (v. 477-547) do canto II, Anquises (v. 679-892) dos cantos II e III. Esse canto de fato configura uma catarse de Enéias.

Ao tratar dessa questão, Otis (1964, p. 290-297) conclui que Enéias encontra seu passado no Hades a fim de poder superá-lo; nessa perspectiva, Deífobo simbolizaria Tróia, e o fato de voltar as costas para Enéias significaria que esse herói deve voltar as costas ao passado e concentrar-se no futuro: Roma e sua história.

Do ponto de vista estrutural, de acordo com Knauer (1981, p. 878), Virgílio teria imitado a seguinte sequiência homérica:

\begin{tabular}{|l|l|}
\hline \multicolumn{1}{|c|}{ Odisséia } & \multicolumn{1}{c|}{ Eneida } \\
\hline Final do canto X (v. 469-574) & Final do canto V (v. 700-871) \\
\hline Canto XI & Canto VI \\
\hline Começo do canto XII (v. 1-15) & Começo do VII (v. 1-20) \\
\hline
\end{tabular}

Essa configuração confirma a Odisséia como modelo estrutural do horizonte traçado com os seis cantos iniciais da Eneida.

Nesse canto ocorrem algumas referências a poemas perdidos do ciclo troiano (apresentadas na introdução deste capítulo): Enéias evoca o Etíope ao aludir à morte de Aquiles pelas mãos de Páris, propiciada por Apolo (v. 56-58); a Sibila evoca os Cantos Cíprios ao aludir ao nascimento de Aquiles e a uma guerra causada pela união de uma mulher com um estrangeiro (v. 89-94); Enéias evoca os Cantos Cíprios ao aludir ao sacrifício de Pólux pelo irmão, à morte alternada (v. 121-122); a alma de Deífobo evoca o Saque de Ílion ao relatar acontecimentos do assalto da cidade (v. 509-529).

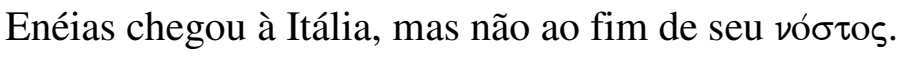




\section{Conclusão do capítulo}

As pinturas do templo de Juno evocam os Cantos Cíprios, a Ilíada e o Etíope; e neste capítulo constatou-se que outros poemas do ciclo troiano são evocados ao longo dos seis cantos iniciais da Eneida.

As análises aqui efetuadas desvelam a seguinte composição: o canto II apresenta uma versão da queda de Tróia, cuja elaboração recorre em especial à Pequena Ilíada e ao Saque de

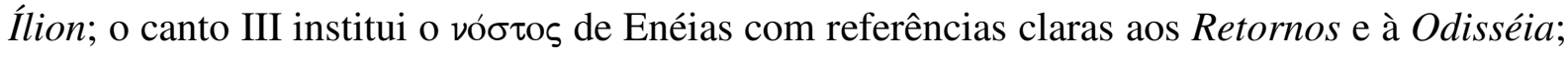

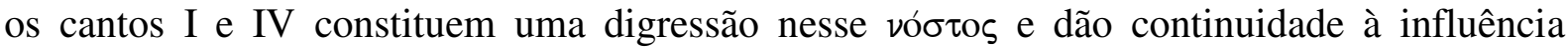
estrutural da Odisséia; o canto V volta ao ponto de partida da digressão e desse modo retoma

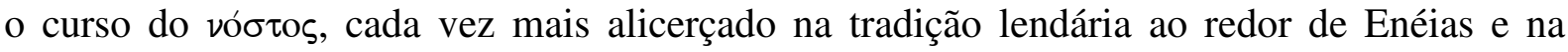
história romana, mas sem perder a influência estrutural da Odisséia, que se estende ao canto VI, com a nekyia. Tendo em vista essa sinopse, os seis primeiros cantos evocam os seguintes poemas: a Pequena Ilíada e o Saque de Ílion combinados no canto II; os Retornos e a Odisséia combinados nos cantos III, I-IV, V e VI (em ordem cronológica).

Atrelando essa evocação à das pinturas do templo de Juno, "reedita-se" o ciclo troiano ex ordine (com exceção da Telegonia), e agora em função de Enéias. Por conseguinte, comprova-se o quarto e último pressuposto desta tese.

Uma última palavra a respeito da composição arquitetural dos seis cantos iniciais da Eneida. Seu horizonte de significação apresenta ao menos dois planos de sentido: em um primeiro, vê-se a Odisséia como modelo estrutural; detrás desse, vislumbra-se uma "reedição" do ciclo troiano principiada no episódio das pinturas do templo de Juno. Não há conflito entre esses planos, inclusive se unem no momento em que a Odisséia assume seu papel nesse ciclo.

Essa arquitetura denuncia grande engenho. Cabe ao receptor reconhecer indícios fornecidos por ela e a partir deles concretizar sentidos nela estocados. 
Visualização da arquitetura dos seis cantos iniciais da Eneida segundo suas relações com o ciclo troiano

Digressão por Cartago

Progressão do ciclo troiano

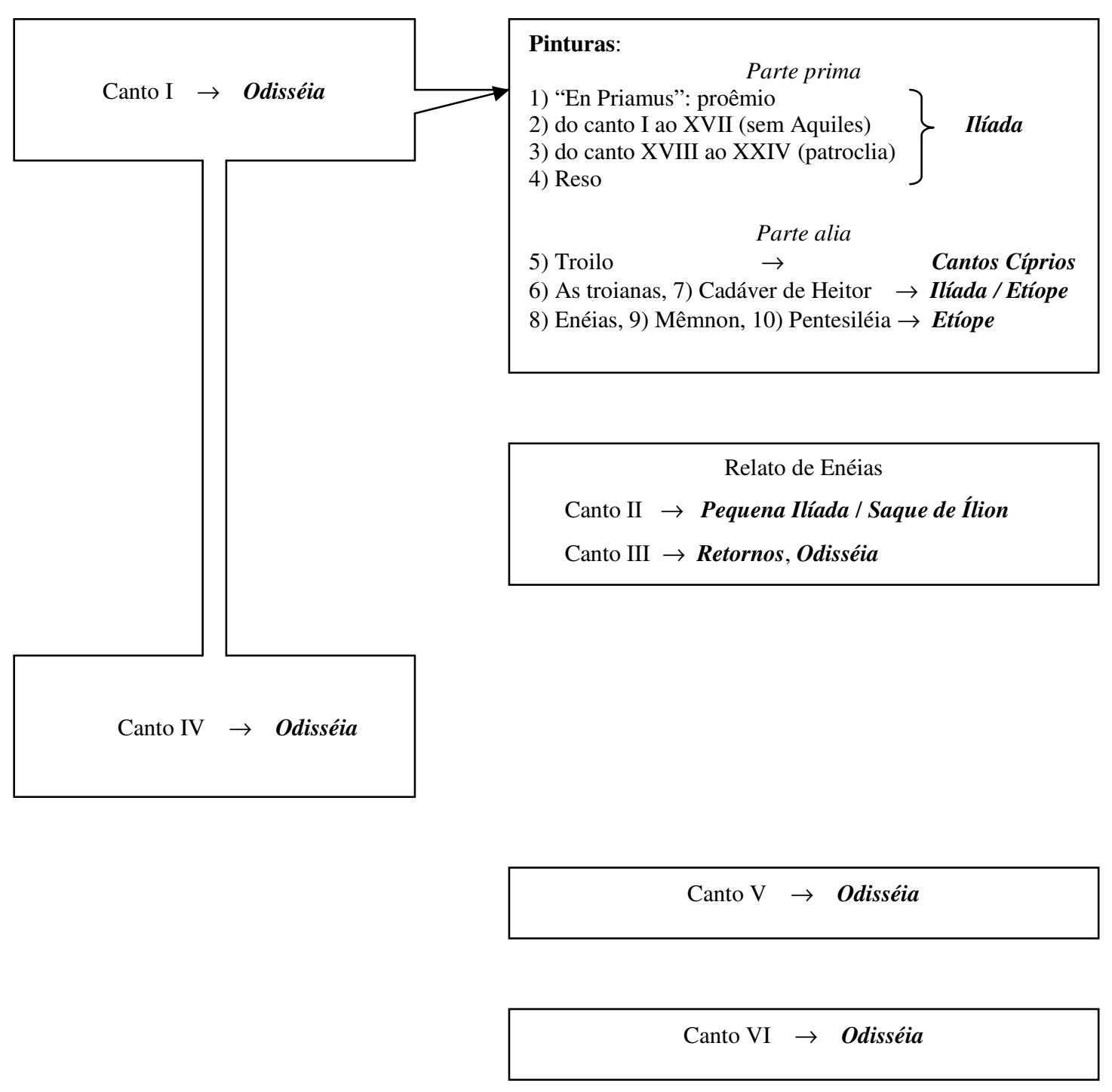


c on c lus ã o

Hoc primum in luco noua res oblata timorem leniit, hic primum Aeneas sperare salutem ausus et adflictis melius confidere rebus.

(Eneida, I, v. 450-452)

Ao fim dessa leitura da Eneida, retornemos ao ponto de partida: as pinturas no templo de Juno. Vejamos agora como Virgílio prepara o advento desse episódio.

Antes de entrar propriamente em Cartago, em companhia de Acates, Enéias vivencia uma manifestação divina (I, v. 305-417): Vênus lhes aparece, faz revelações e os envolve com um manto de névoa. Assim protegidos, encaminham-se para a cidade nascente. No centro dela, encontram um bosque sagrado (Lucus in urbe fuit media, v. 441), onde os púnicos, ao chegarem à região, descobriram um sinal de Juno: a cabeça de um fogoso cavalo, augúrio de ventura bélica. A sacralização do lugar se materializa com a construção de um templo em honra de Juno (Hic templum Iunoni ingens Sidonia Dido / condebat, v. 446-447). Nesse templo, encontram-se as pinturas.

Ao conduzir Enéias até essas pinturas, Virgílio idealiza um movimento tendente ao centro, ao interior: de início, Enéias contempla Cartago do alto de uma colina (ascendebant collem, v. 419); depois desce e dirige-se ao centro da cidade, onde encontra o bosque sagrado, no interior do qual há um templo, no interior do qual o herói divisa as pinturas. Relacionadas aqui pela correspondência interior-interior, as duas últimas etapas dessa condução também se mostram equiparadas no que concerne à elaboração textual: a descrição do bosque estende-se por nove versos (v. 441-449); em seguida, vêm os nove versos introdutores das pinturas (v. 450-458). Tal simetria reverbera ainda no conteúdo: nesse bosque, os púnicos, que fugiam de Sídon pelo mar (iactati undis, v. 442), receberam pela primeira vez (primum, v. 442) um sinal de ventura; nesse bosque, Enéias, fugindo de Tróia pelo mar (iactatus alto, I, v. 3; iactatum, VI, v. 693), há de receber pela primeira vez (primum, v. 451) um sinal de ventura. O sinal dos púnicos consiste em uma cabeça de cavalo, o qual pode ser considerado uma "imagem" que exige uma interpretação (essa simbologia sabe a uma linguagem pictórica); e o sinal de Enéias, como sabemos, consiste nas imagens do 
templo, plenas de significação, instrumentos de uma verdadeira linguagem pictórica capaz de propiciar as diversas interpretações concretizadas nesta leitura.

Essa cuidadosa preparação do advento das pinturas culmina nos versos da epígrafe (discutidos na introdução do capítulo II), núncios de que algo inesperado (noua res) e muito significativo acontecerá nesse bosque sagrado (Hoc in luco).

Com essa engenhosa estruturação, Virgílio dimensiona e reveste de uma aura divina a amplitude do episódio das pinturas do templo de Juno... a qual se comprovou ao longo desta investigação.

Com efeito, o princípio de que essas pinturas evocariam em especial epopéias do ciclo troiano evidenciou-se profícuo, pois todas as imagens possibilitaram a concretização de sentidos relacionados a esse ciclo. Em conseqüência, emergiram nos versos da Eneida temas pertinentes aos poemas cíclicos, como a característica peculiar de Enéias na saga troiana (a sobrevivência), a sorte distinta dos ramos descendentes de Dárdano e suas implicações para a missão de Enéias e o destaque concedido a oráculos e rituais mágico-religiosos. Nessa perspectiva, a cena do reconhecimento de Enéias obteve um benefício elevado: os estudiosos da Eneida não conseguiam vinculá-la a uma fonte segura; ela agora sugere a participação do herói no momento mais importante do Etíope, isto é, na luta pelo cadáver de Aquiles. Na lenda de Enéias, esse momento se destaca por marcar seu retorno ao combate: no canto XX da Ilíada, Posídon o salva de Aquiles e o proíbe de lutar até a queda do pelida. Em síntese, nessa imagem vê-se a volta de Enéias ao palco da saga troiana, em grande estilo.

Outra relevante contribuição aos estudos da Eneida propiciada por esse princípio analítico reside na descoberta de uma lógica na disposição das pinturas, justificando enfim a contestada expressão ex ordine. Como se viu, essa disposição destaca inicialmente a Ilíada; em seguida, apresenta os três primeiros épicos do ciclo troiano em ordem. Com esse arranjo, mimetiza-se o processo de formação desse ciclo e prepara-se o terreno para que sua seqüência se manifeste na metade odissíaca do poema.

Como resultado desse desdobramento do episódio das pinturas nos seis cantos iniciais da Eneida, o ciclo troiano é "reeditado" em função de Enéias. Na conclusão da parte I do capítulo II, em decorrência de um comentário de Aristóteles (Poética, 1459a-b) a respeito da noção de unidade, percebemos que poetas cíclicos trabalhavam com a idéia de um herói principal para cada épico e que isso teria gerado subdivisões, como um "ciclo de Aquiles" 
formado pelos poemas Cantos Cíprios, Ilíada e Etíope. Embora Enéias desempenhe um papel relevante na Ilíada (em particular no canto XX) e provavelmente fosse figura de realce no Etíope e no Saque de Ílion, não era o protagonista de nenhum épico desse ciclo. Com a Eneida, Virgílio não somente criou o épico de Enéias nesse ciclo mas ainda compôs praticamente um "ciclo de Enéias" em um só poema.

Essa "reedição" do ciclo vem acompanhada de uma reelaboração da lenda desse herói. Nesse processo, salienta-se a grande dependência da Eneida em relação ao canto XX da Ilíada, de onde emana a missão e, por conseguinte, a lenda de Enéias.

E a Odisséia, como há muito se sabe, é fundamental nessa primeira metade da Eneida, funcionando como modelo estrutura, fonte e modelo de episódios. Nesse intenso diálogo com esse poema homérico, convém retomar nesse momento um detalhe significativo para nossa investigação: a percepção e a utilização de um procedimento metapoético que transparece no segundo canto de Demódoco. Virgílio percebeu que um aedo divulga poesia épica no interior de uma epopéia e usou a inspiração desse procedimento na elaboração do episódio das pinturas. Esse detalhe também argumenta a favor do uso e da encenação da teoria da arte da memória nesse episódio e nos encaminha às sendas do fazer poético.

Dispostas ex ordine e representando conteúdos do "discurso" do ciclo troiano, as imagens do templo de Juno claramente empregam recursos da mnemotécnica; além disso, o fato de Enéias percorrê-las com o olhar e realimentar sua memória nesse processo denuncia a encenação do método mnemônico fundado em imagines et loci e destinado à memória de assuntos (rerum memoria), preceituado na Rhetorica ad Herennium (III, 28-40), no De Oratore (II, 350- 360) e na Institutio Oratoria (XI, 2, 1-51). Tal procedimento constitui um sinal dos tempos. Para um aedo da tradição oral como Demódoco, a Memória é fundamental, é a verdadeira mãe da poesia; e ela vem por intermédio da invocação à Musa. Para um orador da época de Virgílio, a memória é fundamental e vem por intermédia da retórica. Virgílio, fazendo as vezes de um aedo da tradição oral, recorre à entidade Memória no princípio de seu poema (Musa, mihi causas memora, I, v. 8); por outro lado, como um poeta de seu tempo, recorre à retórica em busca de recursos para a composição poética - no caso do episódio das pinturas, recorre à arte da memória. Esse episódio suscita assim uma reflexão a respeito do fazer poético: de um lado, Virgílio deve resgatar uma tradição que remonta aos poemas homéricos e nela inserir-se (deve emular com Homero); de outro, deve empregar 
procedimentos poéticos em vigor em sua época, ou seja, usar sobretudo técnicas exploradas pela poesia alexandrina e, em grande parte, decorrentes de uma verdadeira retoricização da poesia. Com isso, na Eneida dão-se as mãos a "antiga" Musa e a "nova" musa, a retórica.

Complementemos essa reflexão com um cotejo entre a aventura de Enéias e a da Eneida na primeira metade desse poema. O herói sai do canto sexto revigorado, e essa epopéia sai desse canto tendo revivido o ciclo troiano, ao qual dá continuidade. Assim como o herói defrontou-se com seu passado em sua catábase, o poema lida nesses cantos com o passado épico que abordam a temática da guerra de Tróia. Em conseqüência, essa aventura da Eneida sugere sua catábase poética.

Em verdade, a viagem de Tróia até a Itália não é apenas geográfica, é também uma viagem poética... Principia nas águas da Ilíada, atravessa o ciclo troiano e aporta na Eneida. E o episódio das pinturas do templo de Juno é o porto de onde parte essa frota de Virgílio.

Nunc do fatis uela... 
bibliografia

\section{Edições de autores antigos}

AESCHYLUS. Vol. I: The Suppliant Maidens, The Persians, Prometheus Bound, The Seven Against Thebes; vol. II: Agamemnon, The Libation-bearers, Eumenides, Fragments. London: William Heinemann, 1926. 2v. (Loeb).

Agamemnon. A translation with commentary by Hugh LLOYD-JONES. London: Prentice-Hall, 1970.

Anthologie Grecque, première partie: Anthologie Palatine, tome IV: livre VII, épigr. 1-363. Texte établi par Pierre WALTZ et traduit par A. M. DESROUSSEAUX, A. DAIN, P. CAMELOT et E. des PLACES. Paris: Société d’Édition “Les Belles Lettres”, 1960.

APOLLODORO. Biblioteca. Con il commento di James G. FRAZER, edizione a cura di Giulio GUIDORIZZI. Milano: Adelphi Edizioni, 1995.

APOLLODORUS. The Library. Translated by Sir James G. FRAZER. London: William Heinemann, 1921. 2v. (Loeb).

APOLLONIOS DE RHODES. Argonautiques. Texte établi et commenté par Francis VIAN, traduit par Émile DELAGE et Francis VIAN. Paris: Société d'Édition "Les Belles Lettres", 1974, tome I (chants I-II); 1980, tome II (chant III); 1981, tome III (chants IV).

ARISTOPHANES. Clouds, Wasps, Peace. Edited and translated by Jeffrey HENDERSON. Cambridge (Massachusetts)-London: Harvard University Press, 1998. (Loeb).

ARISTOTE. Poétique. Texte établi et traduit par J. HARDY. Paris: Société d'Édition "Les Belles Lettres", 1932.

Rhétorique, livre III. Texte établi et traduit par Méderic DUFOUR et André WARTELLE, annoté par WARTELLE. Paris: Société d'Édition “Les Belles Lettres”, 1989. ARISTÓTELES. Poética. Tradução de Eudoro de Souza. Edição bilíngüe. São Paulo: Ars Poetica, 1992.

ATHENAEUS. The Deipnosophists. Translated by Charles B. GULICK. London: William Heinemann (Loeb), 1927, vol. I (1a-106e); 1928, vol. II (106e-222b); 1999, vol. III (222b330c); 1930, vol. IV (331a-459c); 1933, vol. V (459c-554f); 1937, vol. VI (555a-653b); 1941, vol. VII (653b-702b). 
BUCOLIQUES GREC, tome I: Théocrite. Texte établi et traduit par Ph.-E LEGRAND. Paris: Société d'Édition “Les Belles Lettres”, 1946.

, tome II: PSEUDO-THÉOCRITE, MOSCHOS, BION, DIVERS. Texte établi et traduit par Ph.-E LEGRAND. Paris: Société d'Édition “Les Belles Lettres”, 1927.

CALLIMAQUE. Les Origines, Réponses aux Telchines, Élégies, Épigrammes, Iambes et Pièces Lyriques, Hécalé, Hymnes. Texte établi et traduit par Émile CAHEN. Paris: Société d'Édition "Les Belles Lettres", 2002 (1922).

CATULLE. Poésies, texte établi et traduit par Georges LAFAYE. Paris: Société d'Édition "Les Belles Lettres", 1984.

CICÉRON. De l'Orateur, livre deuxième. Texte établi et traduit par Edmond COURBAUD. Paris: "Les Belles Lettres", 1927.

DÉMÉTRIOS. Du Style. Texte établi et traduit par Pierre CHIRON. Paris: Société d'Édition "Les Belles Lettres", 1993.

DENYS D'HALICARNASSE. Antiquités Romaines, tome I: Introduction générale et Livre I. Texte établi et traduit par Valérie FROMENTIN. Paris: Société d'Édition "Les Belles Lettres", 1998.

ESCHYLE. Agamemnon, Les Choéphores, Les Euménides. Texte établi et traduit par Paul MAZON. Paris: Société d'Édition “Les Belles Lettres”, 1952.

Les Suppliantes, Les Perses, Les Sept contre Thèbes, Prométhée Enchaîné. Texte établi et traduit par Paul MAZON. Paris: Société d’Édition “Les Belles Lettres”, 1949.

EURIPIDE. Hélène, Les Phéniciennes. Texte établi et traduit par Henri GRÉGOIRE (pour Hélène) et par Louis MÉRIDIER (pour Les Phéniciennes). Paris: Société d'Édition "Les Belles Lettres", 1950.

. Tragédies, tome VII, $2^{e}$ partie: Rhésos. Texte établi et traduit par François JOUAN. Paris: Société d'Édition “Les Belles Lettres”, 2004.

. Tragédies, tome VIII, $1^{e}$ partie: fragments de Aigeus à Autolykos. Texte établi et traduit par François JOUAN et Herman VAN LOOY. Paris: Société d'Édition "Les Belles Lettres", 1998.

Tragédies, tome VIII, $3^{e}$ partie: fragments de Sthénébée à Chrysippos. Texte établi et traduit par François JOUAN et Herman VAN LOOY. Paris: Société d’Édition "Les Belles Lettres", 2002. 
Tragédies, tome VIII, $4^{e}$ partie: fragments de drames non identifiés. Texte établi et traduit par François JOUAN et Herman VAN LOOY. Paris: Société d'Édition "Les Belles Lettres", 2003.

Oreste. Texte établi et annoté par Fernand CHAPOUTHIER et traduit par Louis MÉRIDIER. Paris: Société d'Édition “Les Belles Lettres”, 1959.

Euripidis Opera Omnia, vol. V: (IФІГENEIA 'H EN TAYPOІ $\Sigma$, PE $\Sigma \mathrm{O} \Sigma$, TP $\Omega A \Delta \mathrm{E} \Sigma$; Scholia in Rhesos, in Troadas. Latina interpretatione, scholiis antiquis et eruditorum obseruationibus illustrata. Glasgueae: Ex Prelo Academico, 1821.

EVELYN-WHITE, H. G. Hesiod, the Homeric Hymns and Homerica. London: William Heinemann, 1914. (Loeb).

HERÁCLITO. Alegorías de Homero. Madrid: Editorial Gredos, 1989.

HÉRODOTE. Histoires. Texte établi et traduit par Ph.-E. LEGRAND. Paris: Société d'Édition "Les Belles Lettres", 1936, vol. II: Livre II; 1949, vol. IV: Livre IV.

HÉSIODE. Théogonie, Les travaux et les jours, Le bouclier. Texte établi et traduit par Paul MAZON. Paris: Société d'Édition "Les Belles Lettres”, 1986.

HESÍODO. O escudo de Heracles. Tradução de Jaa Torrano. Hypnos 6, p. 185-221, 2000.

Os trabalhos e os dias. Introdução, tradução e comentários de Mary de Camargo Lages. São Paulo: Iluminuras, 1996.

Teogonia. Estudo e tradução de Jaa Torrano. São Paulo: Iluminuras, 2001.

HOMÈRE. Hymnes. Texte établi et traduit par Jean UMBERT. Paris: Société d'Édition "Les Belles Lettres", 1959.

Iliade. Texte établi et traduit par Paul MAZON. Paris: Société d'Édition "Les Belles Lettres", 1937, tome I (chants I-VI); 1972, tome II (chants VII-XII); 1974, tome III (chants XIII-XVIII); 1963, tome IV (chants XIX-XXIV).

L'Odyssée. Texte établi et traduit par Victor BÉRARD. Paris: Société d'Édition "Les Belles Lettres", 1972, tome I (chants I-VII); 1974, tome II (chants VIII-XV); 1967, tome III (chants XVI-XXIV).

HOMERO. Ilíada. Tradução de Haroldo de Campos. São Paulo: Editora ARX, 2001, vol. I (Cantos I-XII); 2002, vol. II (Cantos XIII-XXIV).

. Ilíada. Tradução em versos de Carlos Alberto Nunes. Rio de Janeiro: Ediouro, 2001. 
Odisséia. Tradução em versos de Carlos Alberto Nunes. Rio de Janeiro: Ediouro, 2002.

. Odisséia. Tradução em prosa de Antônio P. de Carvalho. São Paulo: Nova Cultural, 2002.

HORACE. Euvres. Paris: Hachette, 1909.

Odes et Épodes. Paris: Société d'Édition “Les Belles Lettres”, 1954.

HYGIN. Fables. Texte établi et traduit par Jean-Yves BORIAUD. Paris: Société d'Édition "Les Belles Lettres", 1997.

IGINO. Miti. A cura di Giulio GUIDORIZZI. Milano: Adelphi Edizioni, 2000.

LAMBIN, Gérard. L'Alexandra de Lycophron. Rennes: Presses Universitaires de Rennes, 2005 .

Le Premier Mythographe du Vatican. Texte établi par Nevio ZORZETTI et traduit par Jacques BERLIOZ. Paris: Société d'Édition “Les Belles Lettres”, 1995.

OPPIAN. Cynegetica, Halieutica. With an english translation by A. W. MAIR. London: William Heinemann LTD, 1928. (Loeb).

ORAZIO. Arte Poetica, introduzione e commento di Augusto ROSTAGNI. Torino: Loescher Editore, 1986.

OVID. FASTI. With an English translation by Sir James George FRAZER. London: William Heinemann LTD, 1959. (Loeb).

OVIDE. Les Métamorphoses, tome I (I-V). Texte établi et traduit par Georges LAFAYE. Paris: Société d’Édition “Les Belles Lettres”, 1985. tome II (VI-X). Texte établi et traduit par Georges LAFAYE, revu et corrigé par H. LE BONNIEC. Paris: Société d'Édition “Les Belles Lettres”, 1989. , tome III (XI-XV). Texte établi et traduit par Georges LAFAYE. Paris: Société d'Édition "Les Belles Lettres", 1988.

PAUSANIAS. Description of Greece, vol. IV: book VIII, Arcadia; book IX, Boeotia; book X, Phocis, Ozolian Locri. Translated by W. H. S. JONES. London: William Heinemann LTD, 1935. (Loeb). , vol. II: book III, Laconia; book IV, Messenia; book V, Elis I. Translated by W. H. S. JONES and H. A. ORMEROD. London: William Heinemann LTD, 1926. (Loeb). 
vol. I: book I, Attica; book II, Corinth. Translated by W. H. S. JONES. London: William Heinemann LTD, 1918. (Loeb).

PHILODEMUS. On Poems, Book 1. Edited with introduction, translation, and commentary by Richard JANKO. Oxford: Oxford University Press, 2000.

On Piety, Part 1. Edited with critical text and commentary by Dirk OBBINK. Oxford: Clarendon Press, 1996.

PHOTIUS. Bibliothèque, tome V: "Codices" 230-241. Texte établit et traduit par René HENRY. Paris: Société d'Édition "Les Belles Lettres”, 1967.

PINDARE. Néméennes, tome III. Texte établit et traduit par Aimé PUECH. Paris: Société d'Édition “Les Belles Lettres”, 1967.

Isthmiques et fragments, tome IV. Texte établit et traduit par Aimé PUECH. Paris: Société d’Édition “Les Belles Lettres”, 1961.

PLATON. Phèdre. Traduction, introduction et notes par Luc BRISSON. Paris : Flammarion, 1989.

Euvres Complètes, tom. IV, partie 3: Phèdre. Texte établi et traduit par Léon ROBIN. Paris: Société d’Édition “Les Belles Lettres”, 1966.

PLINE L'ANCIEN. Histoire Naturelle XXXV: La Peinture. Paris: Société d'Édition "Les Belles Lettres", 2001. Classiques en Poche.

PLUTARQUE. Euvres Morales, tome I, $1^{\text {re }}$ partie: "De l'Éducation des Enfants", “Comment Lire les Poètes". Le texte du premier traité a été établi et traduit par Jean SIRINELLI, du deuxième par André PHILIPPON. Paris: Société d'Édition “Les Belles Lettres”, 1987.

. Vies: tome I: Thésée-Romulus, Lycurgue-Numa. Texte établi et traduit par Robert FLACELIÈRE. Paris: Société d’Édition “Les Belles Lettres”, 1957.

PROCLUS. Chrestomathia: excerpta leguntur in codicis Veneti 454 foliis primo, sexto et quarto. In: DINDORFIUS, 1875, tomus I, p. xxxi-xli.

PROPERCE. Élégies. Texte établie et commenté par Simone VIARRE. Paris: Société d'Édition "Les Belles Lettres", 2005.

PSEUDO-ARISTOTE. Rhétorique à Alexandre, texte établi et traduit par Pierre CHIRON. Paris: Société d’Édition “Les Belles Lettres”, 2002.

QUINTILIEN. Institution oratoire, tome VI: Livres X-XI. Texte établi et traduit par J. COUSIN. Paris: Société d'Édition "Les Belles Lettres”, 1979. 
QUINTO CURZIO RUFO. Storie di Alessandro Magno, vol. I: Libri III-IV. Traduzione di Virginio ANTELAMI. Italia: Arnoldo Mondadori Editore, 1998.

- Storie di Alessandro Magno, vol. II: Libri III-IV. Traduzione di Tristano GARGIULO. Italia: Arnoldo Mondadori Editore, 2000.

QUINTUS DE SMYRNE. La suite d'Homère. Texte établi et traduit par Francis VIAN. Paris: Société d'Édition “Les Belles Lettres”, 1963, tome I (livres I-IV); 1966, tome II (livres V-IX); 1969, tome III (livres X-XIV).

Rhétorique à Hérennius, texte établi et traduit par Guy ACHARD. Paris: Société d'Édition "Les Belles Lettres", 1989.

Rhétorique à Hérennius, texte revu et traduit par Henri BORNECQUE. Paris: Garnier, s/d.

SOPHOCLE. Ajax, Edipe Roi, Électre. Texte établi par Alphonse DAIN et traduit par Paul MAZON. Paris: Société d'Édition “Les Belles Lettres”, 1965.

STRABO. The Geography, vol. VI: books XIII and XIV. London: William Heinemann, 1929. STRABON. Géographie, tome I, $1^{\text {re }}$ partie (introduction générale - Livre 1). Texte établi et traduit par Germaine AUJAC. Paris: Société d’Édition “Les Belles Lettres”, 1969.

TITE-LIVE. Histoire Romaine, tome I: livre I. Texte établi par Jean BAYET et traduit par Gaston BAILLET. Paris: Société d'Édition “Les Belles Lettres”, 1971.

THUCYDIDES. History of the Peloponnesian War, vol. III: books V and VI. CambridgeMassachusetts: Harvard University Press, 1959.

VIRGILE. Bucoliques. Paris: Société d'Édition “Les Belles Lettres”, 1978. Énéide. Texte établi et traduit par Jacques PERRET. Paris: Société d'Édition "Les Belles Lettres", 1977, tome I (livres I-IV); 1989, tome II (livres V-VIII); 1980, tome III (livres IX-XII).

Énéide, tome II: livres VII-XII. Texte établi par René DURANT et traduit par André BELLESSORT. Paris: Société d'Édition "Les Belles Lettres”, 1948.

Énéide, tome I: livres I-VI. Texte établi par Henri GOELZER et traduit par André BELLESSORT. Paris: Société d'Édition "Les Belles Lettres”, 1925.

VIRGÍlLIO. Eneida. Tradução de Tassilo Orpheu Spalding. São Paulo: Cultrix, 1992.

VIRGILIO. Eneide. Traduzione di Luca CANALI, introduzione e commento di Ettore PARATORE. Milano: Oscar Mondadori, 1991. . Eneide. Traduzione di Rosa C. ONESTI. Torino: Einaudi Tascabili, 1989. 
VIRGILIVS. Aeneidis libri I-VI. Varietate lectionis et perpetua adnotatione illustratus a C. G. HEYNE. Lipsiae: Libraria Hahniana, 1832.

WEST, Martin L. Homeric Hymns, Homeric Apocrypha, Lives of Homer. Cambridge (Massachusetts)-London: Harvard University Press, 2003b. (Loeb).

\section{Estudos}

AGUILAR, Rosa M., "La Figura de Télefo en la Literatura y en el Arte Griegos", Cuadernos de Filología Clásica: Estudios griegos e indoeuropeos, 13, 2003, p. 181-193.

ALEXANDER, William Hardy, “Aeneid, I, 462: a New Approach”, American Journal of Philology, 75, 1954, p. 395-400.

ALLEN, Thomas W. Homer. The Origins and the Transmission. Oxford: Clarendon Press, 1924.

, “The Epic Cicle”, Classical Quarterly, 2, 1908, p. 68-71.

ANDERSON, M. J. The Fall of Troy in Early Greek Poetry and Art. Oxford: Clarendon Press, 1997.

ARIAS, Paolo Enrico. Mille Anni di Ceramica Greca. Fotografie di Max HIRMER. Firenze: Sansoni, 1960.

ARIAS, P.E.; HIRMER, M.; SHEFTON, B.B. A History of Greek Vase Painting. London: Thames and Hudson, 1962.

AUSTIN, R. G., "Virgil, Aeneid 2. 567-88”, Classical Quarterly, 11 (N. S.), 1961, p. 185198.

, "Virgil and the Wooden Horse", Journal of Roman Studies, 49, 1959, p. 16-25.

AUVRAY-ASSAYAS, Clara (édit.). Images Romaines, Actes de la table ronde organisée à l’École Normale Supérieure (-24-26 octobre 1996). Paris: Presses de l’École Normale Supérieure, 1998.

AVERY, William T., “Mentem Mortalia Tangunt”, Classical Philology, 48, 1953, p. 19-20.

BAILEY, Cyril. Religion in Virgil. Oxford: Clarendon Press, 1935.

BARCHIESI, Alessandro. "Representations of Suffering and Interpretation in the Aeneid", in: Virgil Critical Assessments of Classical Authors, 1999 (1994), p. 324-344. 
BAROIN, Catherine, "La Maison Romaine comme Image et lieu de Mémoire", in: AUVRAY-ASSAYAS, Clara (édit.). Images Romaines, Actes de la table ronde organisée à l'École Normale Supérieure (24-26 octobre 1996). Paris: Presses de l’École Normale Supérieure, 1998, p. 177-191.

BASCHERA, Claudio. Ipotesi d'una Relazione tra il Servio Danielino e gli Scolii Veronesi a Virgilio. Verona: Casa Editrice Mazziana, 2000.

BERGMANN, Bettina, "The Roman House as Memory Theater: the House of the Tragic Poet in Pompeii”, The Art Bulletin, 76, 1994, p. 225-256.

BERNABÉ, Alberto P., "Iliad and Aethiopis on the Stage: Aeschylus \& Son", Classical Quarterly, 50 (N. S.), 2000, p. 338-352. , ¿Más de una Ilias Parva?”, Estudios Clásicos, 87, 1984, p. 141-150. , “Cyclica (I)”, Emerita, 50, 1982, p. 81-92.

BEYE, Charles Rowan. Ancient Epic Poetry: Homer, Apollonius, Virgil. Ithaca-London: Cornell University Press, 1993.

BETHE, Erich. Homer. Dichtung und Sage, vol. III: Die Sage von Troischen Kriege. LeipzigBerlin: Teubner, 1927.

Homer. Dichtung und Sage, vol. II: Odyssee, Kyklos, Zeitbestimmung. LeipzigBerlin: Teubner, 1922.

BOARDMAN, John. The History of Greek Vases. London: Thames \& Hudson, 2001.

BOMPAIRE, J. Lucien Écrivain: imitation et création. Paris: E. de Boccard Éditeur, 1958.

BOYANCÉ, Pierre, "Les origines de la légende troyenne de Rome", Revue des Études Anciennes, 45, 1943, p. 275-290.

BOYLE, A. J. Roman Epic. London: Routledge, 1996.

BRACCESI, L. “Appunti su Sofocle e la legenda di Enea”, in: CORSINI, E. (edit.). La polis e il suo teatro, vol. I. Padova: Editoriale Programma, 1986, p. 103-110.

BRAGA, Domenico. Catullo e i Poeti Greci. Messina: Casa Editrice G. D’Anna, 1950.

BRAVO, B., "Un frammento della Piccola Iliade (P. Oxy. 2510), lo stile narrativo tardoarcaico, i racconti su Achille immortale", Quaderni Urbinati di Cultura Classica, 67, 2001, p. 49-114.

BREMMER, J. N.; HORSFALL, N. M. (edit.). Roman Myth and Mythography. London: RuG, 1987. (Link: http://irs.ub.rug.nl/ppn/288523814). 
BRILlanTE, C. et al. (org.). I Poemi Epici Rapsodici non Omerici e la Tradizione Orale: Atti del convegno di Venezia, 28-30 settembre 1977. Padova: Editrice Antenore, 1981.

BRULÉ, Pierre \& VENDRIES, Christophe. Chanter les Dieux: musique et religion dans l'Antiquité grecque et romaine. Rennes: PUR, 2001.

BRUNA, Jaime. A Poética Clássica: Aristóteles, Horácio e Longino. São Paulo: Cultrix, 1992.

BRUNET, Philippe. La Naissance de la Littérature dans la Grèce Ancienne. Paris: Librairie Générale Française, 1997. (Collection Le livre de poche, Série “Antiquité”).

BULAS, Kazimierz, "New Illustrations to the Iliad", American Journal of Archaeology 54, 1950, p. 112-118.

BURGESS, Jonathan S. The Tradition of the Trojan War in Homer and the Epic Cycle. Baltimore-London: The Johns Hopkins University Press, 2001.

, "The Non-Homeric Cypria", Transactions of the American Philological Association, 126, 1996, p. 77-99.

CADONI, Enzo, "Il Laocoonte di Sofocle", SANDALION, 1, 1978, p. 45-58.

CAIRNS, Francis. Virgil's Augustan Epic. Cambridge: Cambridge University Press, 1990.

CAMERON, Alan. Greek Mythography in the Roman World. Oxford: Oxford University Press, 2004.

CAMPS, W. A. An Introduction to Virgil's Aeneid. Oxford: Oxford University Press, 1969. , "A Note on the Structure of the Aeneid", Classical Quarterly, 4 (N. S.), 1954, p. $214-$ 215.

CARDOSO, Zélia de Almeida. A Literatura Latina. Porto Alegre: Mercado Aberto, 1989.

CARPENTER, Thomas. H. Les Mythes dans l'Art Grec. Paris: Thames and Hudson, 1997.

CARTAUlT, A. L'Art de Virgile dans l'Énéide. Paris: Presses Universitaire de France, 1926. 2 vol.

CASKEY, L. D \& BEAZLEY, J. D. Attic Vase Paintings of Fine Arts: Boston. Oxford: Oxford University Press, 1931.

CASTAGNOLI, F., "La Leggenda di Enea nel Lazio”, Studi Romani, 30, 1982, p. 1-15.

CHRISTIN, Anne-Marie. L’Image Écrite, ou la Déraison Graphique. Paris: Flammarion, 2001.

CITATI, Pietro. La Pensée Chatoyante. Paris: Gallimard, 2002. 
ClÁSSICA. São Paulo: Revista da Sociedade Brasileira de Estudos Clássicos, v. 13/14, n. 13/14, 1998/1999.

CLAUSEN, Wendell. Virgil's Aeneid and the Tradition of Hellenistic Poetry. Berkeley: University of California Press, 1987.

CLAY, Diskin, "The Archaeology of the Temple to Juno in Carthage (Aen. 1. 446-93)", Classical Philology, 83, 1988, p. 195-205.

CONTE, Gian Biagio. Genres and Readers: Lucretius, love elegy, Pliny's encyclopedia. Baltimore: John Hopkins University, 1994.

The Rhetoric of Imitation: genre and poetic memory in Virgil and other Latin poets.

Translated from the Italian, edited and with a foreword by Charles SEGAL. Ithaca-London: Cornell University Press, 1986.

CONWAY, R. S., "Two Difficulties in the Aeneid", Classical Journal, 26, 1931, p. 620-624. , "The Architecture of the Epic", in: CONWAY. Harvard d Lectures on the Vergilian Age. Cambridge-Massachusetts: Harvard University Press, 1928, p. 129-149.

COUAT, Auguste. La Poésie Alexandrine sous les Trois Premiers Ptolémées. Bruxelles: Culture et Civilisation, 1968.

CURTI, M., “L'Officina dei Cicli”, Studi Classici e Orientali, 43, 1993, p. 33-47.

DANGEL, Jacqueline, “Orphée sous le Regard de Virgile, Ovide et Sénèque”, Revue des Études Latines, 77, 1999, p. 87-117.

DAVID, Jean-Michel. La République Romaine. Paris: Éditions du Seuil, 2000.

DAVIES, Malcolm. The Epic Cycle. Bristol: Bristol Classical Press, 1989a. , "The Date of the Cycle”, Glotta, 67, 1989b, p. 89-100.

, "Prolegomena and Paralegomena to a New Edition (with Commentary) of the Fragments of Early Greek Epic”, Nachrichten der Akademie der Wissenschaften in Göttingen, 1986, p. 89-111.

DEBIASI, Andrea. L'Epica Perduta: Eumelo, il Ciclo, l'Occidente. Roma: "L'ERMA" di BRETSCHNEIDER, 2004. (Hesperia, 20).

DEBRAY, Régis. Vida e Morte da Imagem. Petrópolis: Vozes, 1994.

DELLA CORTE, Francesco. La Mappa dell'Eneide. Firenze: La Nuova Italia, 1972.

DESBORDES, Françoise. Concepções sobre a Escrita na Roma Antiga. São Paulo: Ática, 1995. 
La Rhétorique Antique. Paris: Hachette, 1996.

DESPORT, Marie. L'Incantation Virgilienne: Virgile et Orphée. Bordeaux: Delmas, 1952.

DICKSON, Keith. Nestor: poetic memory in Greek epic. New York-London: Garland Publishing, 1995.

DODDS. Les Grecs et l'Irrationnel. Paris: Flammarion, 1977.

DONDIS, Donis A. Sintaxe da Linguagem Visual. São Paulo: Martins Fontes, 1999.

DUCKWORTH, George E. Structural Patterns and Proportions in Virgil's Aeneid. Ann Arbor: The University of Michigan Press, 1962.

, “The Aeneid as a Trilogy", Transactions and Proceedings of the American Philological Association, 88, 1957, p. 1-10.

, "The Architecture of the Aeneid", American Journal of Philology, 75, 1954, p. 1-15.

, "Magical Circles and the Fall of Troy", Classical Journal, 40, 1944, p. 99-103.

, "Suspense in Ancient Epic - an Explanation of Aeneid III", Transactions and

Proceedings of the American Philological Association, 62, 1931, p. 124-140.

DUDLEY, D. R. (edit.). Virgil. New York: Basic Books, 1969.

DUMÉZIL, Georges. Mythe et Épopée, vol. I, II et III. Paris: Gallimard, 1995.

DUNCAN, Thomas S., “The Aeneas Legend on Coins”, Classical Journal, 44.1, 1948, p. 1529.

EGAN, Rory B., “Aeneas at Aineia and Vergil's Aeneid”, Pacific Coast Philology, 9, 1974, p. $37-47$.

ESTEVEZ, Victor A., "Aeneid II 624-631 and the Helen and Venus Episodes", Classical Journal, 76, 1981, p. 318-335.

FARRELL, J. Vergil's Georgics and the Traditions of Ancient Epic: the art of allusion in literary history. New York: Oxford University Press, 1991.

FEDER, Lillian, “Vergil’s Tragic Theme”, Classical Journal, 49, 1953-1954, p. 197-209.

FEENEY, D. C. “'SHALL I COMPARE THEE...?': Catullus 68B and the Limits of Analogy", in: WOODMAN, T \& POWELL, J. (edit.). Author and Audience in Latin Literature. Cambridge: Cambridge University Press, 1992.

FINKELBERG, Margalit, "The Cypria, the Iliad, and the Problem of Multiformity in Oral and Written Tradition”, Classical Philology, 95, n 1, 2000, p. 1-11. 
FOWLER, D. P., "Narrate and Describe: The Problem of Ekphrasis", Journal of Roman Studies", 81, 1991, p. 25-35.

FOWLER, Robert L. Early Greek Mythography, vol. I: Texts. Oxford: Oxford University Press, 2000.

FRAENKEL, Eduard, "Vergil und die Aethiopis", Philologus, 87, 1932, p. 242-248.

FREDERICKSMEYER. "On the Opening of the Aeneid", Vergilius, 30, 1984, p. 10-19.

FRUTIGER, Adrian. Sinais e Símbolos: desenho, projeto e significado. São Paulo: Martins Fontes, 1999.

GALÍ, Neus. Poesía Silenciosa, Pintura que Habla. Barcelona: El Acantilado, 1999.

GALINSKY, G. Karl. Aeneas, Sicily and Rome. Princeton: Princeton University Press, 1969. “Aeneid V and the Aeneid", American Journal of Philology, 89, 1968, p. 157-185.

GANTZ, Timothy. Early Greek Myth: a guide to literary and artistic sources. BaltimoreLondon: The Johns Hopkins University Press, 1993.

GOOLD, G. P., "Servius and the Helen Episode", Harvard Studies in Classical Philology, 74, 1970, p. 101-168.

GOSSAGE, A. J., "Two Implications of the Trojan Legend”, Greece \& Rome, 2 (2nd Ser.), 1955, p. 23-29.

GRAHAM, J. Walter, “The Ransom of Hector on a New Melian Relief”, American Journal of Archaeology, 62, 1958, p. 313-319.

GRANSDEN, K. W., “The Fall of Troy”, Greece \& Rome, 32.1 (2nd Ser), 1985, p. 60-72. Virgil's Iliad: an essay on epic narrative. Cambridge: Cambridge University Press, 1984.

GRIFFIN, J., "The Epic Cycle and the Uniqueness of Homer", Journal of Hellenic Studies, 97, 1977, p. 39-53.

GRIFFITH, R. Drew, “The Origin of Memnon”, Classical Antiquity, 17, 1998, p. 212-234.

GRIMAL, Pierre. Virgile ou La Seconde Naissance de Rome. Paris: Arthaud, 1985.

GRIMM, Richard. "Aeneas and Andromache in Aeneid III", American Journal of Philology, 88, 1967, p. 151-162.

GUERRERO, Gustavo. Teorias de la Lírica. México, D. F.: Fondo de Cultura Económica, 1998.

HAAR, Michel. A obra de arte. Rio de Janeiro: DIFEL, 2000. 
HARDIE, Philip. Virgil's Aeneid: cosmos and imperium. Oxford: Clarendon Press, 1989.

HARRISON, Edward L. "The Structure of the Aeneid: Observations on the Links between the Books”, Aufstieg und Niedergang der Römischen Welt, II.31.1, 1980, p. 359-393.

HAVELOCK, Eric. Prefácio a Platão. Campinas, SP: Papirus, 1996a.

A Revolução da Escrita na Grécia e suas Conseqüências Culturais. São Paulo: Editora da Universidade Estadual Paulista; Rio de Janeiro: Paz e Terra, 1996b.

HEFFERNAN, James A. W. Museum of Words: the poetics of ekphrasis from Homer to Ashbery. Chicago: The University of Chicago Press, 1993.

HEINZE, Richard. Virgil's Epic Technique. Translated by HAZEL, David HARVEY and Fred ROBERTSON. London: Bristol Classical Press, 2004.

HEURGON, J., “Un exemple peu Connu de la 'Retractatio' Virgilienne”, Revue des Études Latines, 9, 1931, p. 258-268.

HEYNE, C. G. "Excursus XV-XIX ad Aeneidis librum I", in: VIRGILIVS. Aeneidis libri IVI. Varietate lectionis et perpetua adnotatione illustratus a C. G. HEYNE. Lipsiae: Libraria Hahniana, 1832.

HILL, H., "Dionysius of Halicarnassus and the Origins of Rome", Journal of Roman Studies, 51, 1961, p. 88-93.

HOLliDAY, Peter J. (edit.). Narrative and Event in Ancient Art. Cambridge: Cambridge University Press, 1993.

HOLT, Philip, “Ajax’s Burial in Early Greek Epic”, American Journal of Philology, 113, 3, 1992, p. 319-331.

HOOKER, J. T. et al. Lendo o Passado: do cuneiforme ao alfabeto, a história da escrita antiga. São Paulo: Editora da Universidade de São Paulo: Companhia Melhoramentos, 1996. HORSFALL, Nicholas M., "The Aeneas Legend from Homer to Virgil”, in: BREMMER, J. N \& HORSFALL, N. M (1987, p. 12-24).

, "Tabulae Iliacae in the Collection Froehner, Paris". Journal of Hellenic Studies, 103, 1983, p. 144-147.

, "Some Problems in the Aeneas Legend", Classical Quarterly, 29 (N. S.), 1979a, p. 372-390.

, “Stesichorus at Bovillae?”, Journal of Hellenic Studies, 99, 1979b, p. 26-48. 
HUXLEY, G. H. Greek epic poetry: from Eumelos to Panyassis. London: Faber and Faber, 1969.

ISER, Wolfgang. O Ato da Leitura. São Paulo: Editora 34, 1999. 2v.

JANKO, Richard. Homer, Hesiod and the Hymns. Cambridge: Cambridge University Press, 1982.

JÍMENEZ, Aurélio Pérez; DÍEZ, Alfonso Martinez. HESÍODO: Obras y Fragmentos. Madrid: Editorial Gredos, 1978. (Biblioteca Clássica Gredos).

JUAN, François. Euripide et les Légendes des Chants Cypriens: des origines de la guerre de Troie à l'Iliade. Paris: Société d'Édition “Les Belles Lettres”, 1966.

KANNICHT, R., "Poetry and Art: Homer and the Monuments Afresh", Classical Antiquity, 1, 1982, p. 70-86.

KEBRIC, Robert B. The Paintings in the Cnidian Lesche at Delphi and their Historical Context. Leiden: Brill, 1983.

KEHOE, Patrick E., "Was Book 5 Once in a Different Place in the Aeneid?", American Journal of Philology, 110, 1989, p. 246-263.

KNAUER, Georg N., "Vergil and Homer", Aufstieg und Niedergang der Römischen Welt, II.31.2, 1981, p. 870-918.

, "Vergil's Aeneid and Homer", Greek, Roman, and Byzantine Studies, 5, 1964a, p. 6184.

Die Aeneis und Homer. Göttingen: 1964b.

KNIGHT, W. F. Jackson. Roman Vergil. London: Faber and Faber, 1944.

, "The Wooden Horse at the Gate of Troy”, Classical Journal, 28, 1933, p. 254-262.

, "Iliupersides”, Classical Quarterly, 26, 1932, p. 178-189.

, "Epilegomena to 'The Wooden Horse'”, Classical Philology, 25, 1931, p. 412-420.

, “The Wooden Horse”, Classical Philology, 25, 1930, p. 358-366.

KNOX, Bernard M. W., "The Serpent and the Flame: the Imagery of the Second Book of the Aeneid", American Journal of Philology, 71, 1950, p. 379-400.

KOPFF, E. Christian, "Virgil and the Cyclic Epics", Aufstieg und Niedergang der Römischen Welt, II.31.2, 1981, p. 919-947.

KONSTAN, David. “Neoteric Epic: Catullus 64”, in BOYLE, 1996, p. 59-78. 
KULLMANN, Wolfgang. Die Quellen der Ilias. Wiesbaden: Franz Steiner Verlag GMBH, 1960. (Hermes Einzelschriften, 14).

LACROIX, L., "Le Périple d'Énée de la Troade à la Sicile: Thèmes Légendaires et Réalités Géographiques", L'Antiquité Classique, 62, 1993, p. 131-155.

LAMBIN, Gérard. L'Épopée: genèse d'un genre littéraire en Grèce. Rennes: PUR, 1999.

LAUSBERG, Heinrich. Manual de Retórica Literária. Madrid: Gredos, 1966.

LAVAUD, Laurent. L'Image. Paris: Flammarion, 1999.

LEONARDI, Elisa Platzeck. A Memória na Retórica Latina. São Paulo: DEDALUS-AcervoFFLCH-LE, 2003.

LESSING, G. E. LAOCOONTE ou sobre as Fronteiras da Pintura e da Poesia. São Paulo: Iluminuras, 1998.

LÉVY, Carlos \& PERNOT, Laurent (org.). Dire l'Évidence. Paris: Editions l'Harmattan, 1997.

LITTLE, Alan M. G., "The Formation of a Roman Style in Wall Painting”, American Journal of Archaeology, 49, 1945, p. 134-142.

Letras Clássicas. São Paulo: Humanitas/FFLCH//USP, 2000, revista do DLCV, ano 4, n 4.

LLOYD, Robert B., “Aeneid III: a New Approach”, American Journal of Philology, 78, 1957a, p. 133-151.

, "Aeneid III and the Aeneas Legend", American Journal of Philology, 78, 1957b, p. $382-400$.

, "Penatibus et Magnis Dis", American Journal of Philology, 77, 1956, p. 38-46.

LORD, Albert Bates. Epic Singers and Oral Tradition. New York: Cornell University Press, 1991.

LOUPIAC, Annic, “Orphée-Gallus, Figure de l'Évolution Morale et Poétique de Virgile des Bucoliques à l'Énéide”, Revue des Études Latines, 79, 2001, p. 93-103.

. L'Arc et la Lyre. Virgile, Auguste et Apollon: Mythes et Politique à Rome. Paris:

L'Harmattan, 1999. (Collection "La philosophie en commun").

LYNCH, John P., "Laocoön and Sinon: Virgil, Aeneid 2.40-198”, Greece \& Rome, 27 (2nd Ser.), 1980, p. 170-179.

LYNE, R.O.A.M. Words and the Poet. Oxford: Clarendon Press, 1989. 
MCCARTNEY, Eugene S., "The Wooden Horse and Folk-Lore of Touching”, Classical Journal, 21, 1925, p. 112-131.

, "The Stopping of the Wooden Horse”, Classical Journal, 19.5, 1924, p. 316.

MACKAIL, J. W., "The Aeneid as a Work of Art", Classical Journal, 26 (n. 1, Special Vergil Number), 1930, p. 12-18.

MACKIE, C. J. The Characterisation of Aeneas. Edinburgh: Scottish Academic Press, 1988.

MARMORALE, Enzo. Naeuius Poeta. Firenze: “La Nuova Italia” Editrice, 1950.

MARTIN, P. M., “Dans le sillage d’Énée”, Athenaeum, 53, 1975, p. 212-244.

MARTINDALE, Charles (edit.). The Cambridge Companion to Virgil. Cambridge :

Cambridge University Press, 1997.

MASIÁ, Andrés. Ennio, Tragedias: Alcmeo, el Ciclo Troyano. Amsterdam: Adolf M. Hakkert, 2000.

MATHESON, Susan B. Polygnotos and Vase Painting in Classical Athens. Wisconsin: The University of Wisconsin Press, 1995.

MAURY, Paul, "Le Secret de Virgile et l'Architecture des Bucoliques", Lettres d'Humanité, 3, 1944, p. 71-147.

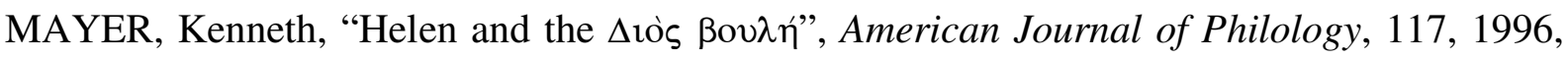
p. 1-15.

MAZON, Paul. Introduction à l'Iliade. Paris: Société d'Édition "Les Belles Lettres”, 1959.

MONRO, D. B., "Homer and the Cyclic Poets", in: , Homer's Odyssey, books XIIIXXIV. Oxford: Clarendon Press, 1901, p. 340-383.

, "The Poems of the Epic Cycle”, Journal of Hellenic Studies, 5, 1884, p.1-41.

, "On the Fragments of Proclus's Abstract of the Epic Cycle Contained in the Codex Venetus of the Iliad", Journal of Hellenic Studies, 4, 1883, p. 305-334.

MORRIS, I. \& POWELL, B. (edit.). A New Companion to Homer. Leiden, New York, Köln: Brill, 1997.

NAGY, Gregory. Greek Mythology and Poetics. Ithaca and London: Cornell University Press, 1990a.

The Lyric Possession of an Epic Past. Baltimore-London: The Johns Hopkins University Press 1990b. 
NETHERCUT, W. R., “The Imagery of the Aeneid”, Classical Journal, 67, 1971-72, p. 12343.

NEWTON, Francis L., "Recurrent Imagery in Aeneid IV", Transactions and Proceedings of the American Philological Association, 88, 1957, p. 31-43.

NORTWICK, Thomas van, “Aeneas, Turnus, and Achilles", Transactions of the American Philological Association, 110, 1980, p. 303-314.

OBBINK, D. Philodemus and Poetry: Poetic Theory and Pratice in Lucretius, Philodemus, and Horace. New York-Oxford: Oxford University Press, 1995.

OGLE, Marbury B., "The House-Door in Greek and Roman Religion and Folk-Lore", American Journal of Philology, 32, 1911, p. 251-271.

OLIVA NETO, João Ângelo. O livro de Catulo. São Paulo: Edusp, 1996.

OLSON, David R. E Nancy Torrance. Cultura Escrita e Oralidade. São Paulo: Ática, 1997.

ONG, Walter J. Oralidade e Cultura Escrita: a tecnologização da palavra. Campinas, SP: Papirus, 1998.

OTIS, Brooks. Virgil: a study in civilized poetry. Oxford: Clarendon Press, 1964.

PASCHALIS, Michael, Virgil's Aeneid: semantic relations and proper names. Oxford: Oxford University Press, 1997.

PAVESE, C. O., "The Rhapsodic Epic Poems as Oral and Independent Poems", Harvard Studies in Classical Philology, 98, 1998, p. 63-90.

PAVIANI, Jayme. Escrita e Linguagem em Platão. Porto Alegre: EDIPUCRS, 1993, Coleção Filosofia-5.

PEREIRA, Maria Helena da Rocha. Estudos de História da Cultura Clássica, vol. II: Cultura Romana. Lisboa: Fundação Calouste Gulbenkian, 1984.

PERRET, Jacques. Virgile: l'homme et l'œuvre. Paris: Hatier, 1952.

Les origines de la Légende Troyenne de Rome. Paris: Société d'Édition "Les Belles Lettres", 1942.

PFEIFFER, Rudolf. Storia della Filologia Classica: dalle origini alla fine dell'Età Ellenistica. Napoli: Gaetano Macchiaroli Libraio Editore, 1973.

PHILLIPS, E. D., “Odysseus in Italy”, Journal of Hellenic Studies, 73, 1953, p. 53-67.

PLEBE, Armando. Breve História da Retórica Antiga. São Paulo: EDUSP, 1978. 
PLEBE, Armando; EMANUELE, Pietro. Manual de Retórica. São Paulo: Martins Fontes, 1992.

PÖSCHL, Viktor. The art of Virgil: image and symbol in the Aeneid. Translated by Gerda SELIGSON. Ann Arbor: The University of Michigan Press, 1970.

POUCET, J., "Denys d'Halicarnasse et Varron: le Cas des Voyages d'Énée”, Mélanges d'Archéologie et d'Histoire de l'École Française de Rome, 101, 1989, p. 63-95.

PUTNAM, Michael C. J. Essays on Latin Lyric, Elegy and Epic. Princeton: Princeton University Press, 1992.

Virgil's Epic Designs: ekphrasis in the Aeneid. New Haven: Yale University Press, 1998.

, "Unity and Design in Aeneid V", Harvard Studies in Classical Philology, 66, 1962, p. 205-239.

QUINN, Kenneth. Vergil's Aeneid: a critical description. London and Henley: Routledge, 1968.

, "The Fourth Book of the Aeneid: a critical description", Greece \& Rome, 12 (2nd Ser.), 1965, p. 16-26.

RABEL, Robert J., "The Harpies in the Aeneid", Classical Journal, 80, 1985, p. 317-325.

RAMAGE, Nancy H.; RAMAGE, Andrew. Roman Art: Romulus to Constantine. London: Laurence King, 1995.

REBOUL, Olivier. Introdução à Retórica. São Paulo: Martins Fontes, 1998.

REED, J. D. Virgil's Gaze: nation and poetry in the Aeneid. Princeton-Oxford: Princeton University Press, 2007.

REINACH, Adolphe. Textes Grecs et Latins Relatifs à l'Histoire de la Peinture Antique. Paris: Macula, 1985.

REINACH, Solomon. Répertoire des Vases Peints Grecs et Étrusques. Paris: Leroux, 1899, vol. I; 1900, vol. II.

RICOEUR, Paul. A metáfora Viva. São Paulo: Edições Loyola, 2000.

ROBERT, Carl. Die Griechische Heldensage: der Troische kreis bis zu Ilions zerstörung. Berlin: Weidmannsche Buchhandlung, 1923.

. "Homerische Becher", in: Fünfzigstes Programm zum Winckelmannsfeste der Archaeologischen Gesellschaft zu Berlin. Berlin: Georg Reimer, 1890, p. 1-96. 
Bild und Lied. Archäologische Beiträge zur Geschichte der Griechischen Heldensage. Berlin: Weidmannsche Buchhandlung, 1881.

ROHDEN, Luiz. O Poder da Linguagem: a Arte Retórica de Aristóteles. Porto Alegre: EDIPUCRS, 1997.

ROSSI, L. E. "Generi Letterari e le loro Leggi Scritte e non Scritte nelle Letterature Classiche”, Bulletin of the Institute of Classical Studies, 18, 1971, p. 69-94.

ROUVERET, Agnès. Histoire et Imaginaire de la Peinture Ancienne ( $\mathrm{V}^{\mathrm{e}}$ siècle av. J.-C. - $\mathrm{I}^{\mathrm{er}}$ siècle ap. J.-C.). Rome: École Française de Rome, 1989.

RZACH, A., “Kyklus”, RE, XI, 2, 1922, p. 2347-2435.

SADURSKA, Anna. Les Tables Iliaques. Warszawa: PWN, 1964.

SANDERLIN, George, “Aeneas as Apprentice. Point of View in the Third Aeneid", Classical Journal, 71, 1975, p. 53-56.

SANTAELLA, Lúcia \& NÖTH, Winfried. Imagem: cognição, semiótica, mídia. São Paulo: Iluminuras, 1999.

SANTOS, Marcos Marinho dos. Lições sobre Alegoria de Gramáticos e Retores Gregos e Latinos, tese de doutorado. São Paulo: DEDALUS-Acervo-FFLCH-LE, 2002.

SCAFOGLIO, Giampiero, "La Questione Ciclica", Revue de Philologie, de Littérature et d'Histoire Anciennes, 78, 2004, p. 289-310.

,, "Proclo e il Ciclo Epico", Göttinger Forum für Altertumswissenschaft, 7, 2004, p. 39-57 (in: http://gfa.gbv.de/dr,gfa,007,2004,a,03.pdf).

SCAIFE, Ross, “The Kypria and its Early Reception”, Classical Antiquity, 14, 1995, p. 164191.

SEGAL, C, "The Song of Iopas in the Aeneid", Hermes, 99, 1971, p. 336-349.

STANSBURY-O'DONNELL, Mark D., “Polygnotos's Nekyia: a Reconstruction and Analysis", American Journal of Archaeology, 94, 1990, p. 213-235.

SEVERYNS, A. Nouvelles Recherches sur la Chrestomathie de Proclos. Liège, Bulletin de la Classe des Lettres, 6, 1968, p. 301-317.

. Recherches sur la Chrestomathie de Proclos, tome III: La Vita Homeri et Les Sommaires du Cycle: Étude Paléographique et Critique. Paris: Société d'Édition "Les Belles Lettres", 1953. 
Recherches sur la Chrestomathie de Proclos, tome I: Étude Paléographique et Critique; tome II : Texte, Traduction, Commentaire. Paris: Société d'Édition "Les Belles Lettres", 1938.

. "Eustathe et le Cycle Épique", Revue Belge de Philologie et d'Histoire, VII, 1928a, p. 401-457. Le Cycle Épique dans l'École d'Aristarque. Liège-Paris: Édouard Champion, 1928b. , "L'Éthiopide d'Arctinos et la Question du Cycle Épique", Revue de Philologie, 49, 1925, p. 153-183.

SHIPLEY, F. W., "The Virgilian Authorship of the Helen Episode, Aeneid II, 567-588”, Transactions and Proceedings of the American Philological Association, 56, 1925, p. 172184.

SINN, U. Die homerischen Becher. Hellenistische Reliefkeramik aus Makedonien. Berlin: Deutschen Archäologischen Instituts Athenische Abteilung, 1979.

SKUTSCH, O. The Annals of Q. Ennius. Oxford: Clarendon Press, 1985.

SMALL, Jocelyn Penny. Wax Tablets of the Mind: Cognitive Studies of Memory and Literacy in Classical Antiquity. London and New York: Routledge, 1997.

SMITH, P. M., "Aineiadai as Patrons of Iliad XX and the Homeric Hymn to Aphrodite", Harvard Studies in Classical Philology, 85, 1981, p. 17-58.

SOLMSEN, Friedrich, “Aeneas Founded Rome with Odysseus", Harvard Studies in Classical Philology, 90, 1986, p. 93-110.

STANLEY, Keith, "Irony and Foreshadowing in Aeneid, I, 462", American Journal of Philology 86, 1965, p. 267-277.

STANSBURY-O’DONNELL, M. D., "Polygnotos's Nekyia: a Reconstruction and Analysis”, American Journal of Archaeology, 94, 1990, p. 213-235.

, "Polygnotos’s Iliupersis: a New Reconstruction”, American Journal of Archaeology, 93, 1989, p. 203-215.

STEVENSON, Thomas B. Miniature Decoration in the Vatican Virgil: a study in late Antique iconography. Tübingen: Ernst Wasmuth, 1983.

TAPLIN, Oliver. The Stagecraft of Aeschylus: the dramatic use of exits and entrances in Greek tragedy. Oxford: Clarendon Press, 1977. 
THALMANN, William G. Conventions of Form and Thought in Early Greek Epic Poetry. Baltimore and London: The Johns Hopkins University Press, 1984.

THOMAS, Joël. Structures de l'Imaginaire dans l'Énéide. Paris: Société d'Édition "Les Belles Lettres", 1981.

THOMAS, Richard F. Reading Virgil and his Texts: studies in intertextuality. Ann Arbor: University of Michigan Press, 1999.

TIMPANARO, Sebastiano. Virgilianisti Antichi e Tradizione Indireta. Firenze: Leo S. Olschki Editore, 2001.

. Per la Storia della Filologia Virgiliana Antica. Roma: Salerno Editrice, 1986. (Quaderni di “Filologia e Critica”, VI).

Contributi di Filologia e di Storia della Lingua Latina. Roma: Edizioni dell'Ateneo \& Bizarri,1978.

TRABATTONI, Franco. Oralidade e Escrita em Platão. São Paulo: Discurso Editorial; Ilhéus: Editus, 2003.

TRACY, H. L., "Virgil and the Nostoi”, Vergilius, 14, 1968, p. 36-40.

, "Fata Deum and the Action of the Aeneid", Greece \& Rome, 11 (2nd Ser.), 1964), p. 188-195.

_ _The Gradual Unfolding of Aeneas's Destiny”, Classical Journal, 48, 1953, p. 281284.

, “The Pattern of Vergil's Aeneid I-VI", Phoenix, 4, 1950, p. 1-8.

TRAINA. Alfonso. "La traduzione e il tempo: tre versioni del proemio dell'Eneide (1-7)", in: Poeti latini (e neolatini), note e saggi filologicin, III serie. Bologna: Pàtron, 1989.

URE, P. N., “A New Pontic Amphora”, Journal of Hellenic Studies, 71, 1951, p. 198-202.

USSANI Jr., V., "Enea traditore”, Studi Italiani di Filologia Classica, 22, 1947, p. 109-123.

VANOTTI, G. L'altro Enea. La testimonianza di Dionigi di Alicarnasso. Roma: L'Erma di

Bretschneider, 1995.

VASCONCELLOS, Paulo Sérgio de. Efeitos Intertextuais na Eneida de Virgílio. São Paulo: Humanitas/FFLCH/USP: Fapesp, 2001.

VAZQUEZ, José Gonzalez. La Imagen en la Poesía de Virgilio. Granada: Universidade de Granada, 1980.

VELlAY, C., "La Palamédie”, Bulletin de l'Association Guillaume Budé, 1956, p. 55-67. 
VÜRTHEIM, J., “De Eugammonis Cyrenaei Telegonia”, Mnemosyne, 29, 1901, p. 23-58.

WARDEN, John, "Ripae ulterioris amore: Structure and Desire in Aeneid 6", Classical Journal, 95, 2000, p. 349-361.

WEINCKE, M. I., "An Epic Theme in Greek Art”, American Journal of Archaeology, 58, 1954, p. 285-306.

WEST, Martin L., "Iliad and Aethiopis”, Classical Quarterly, 53, 2003c, p. 1-14. , “"Eumelus': a Corinthian Epic Cycle?”, Journal of Hellenistic Studies 122, 2002, p. 109-133.

, “Iliad and Aethiopis on the Stage: Aeschylus \& Son”, Classical Quarterly, 50, 2000, p. 338-352.

, "The Rise of the Greek Epic", Journal of Hellenic Studies, 108, 1988, p. 151-172.

WILliAMS, R. D. “The Pictures on the Dido's Temple”, Classical Quarterly, 10 (N. S.), 1960, p. 145-151.

WISEMAN, T. P., "Roman Legend and Oral Tradition”, Journal of Roman Studies, 79, 1989, 129-137.

WOODFORD, Susan. Images of Myths in Classical Antiquity. Cambridge: Cambridge University Press, 2003.

ZANKER, Paul. Augusto y el Poder de las Imágenes. Madrid: Alianza Editorial, 1992.

\section{Edições de comentários}

AUSTIN, R. G. P. Vergili Maronis Aeneidos Liber Primus. Edited with a commentary. Oxford: Clarendon Press, 1971.

P. Vergili Maronis Aeneidos Liber Secundus. Edited with a commentary. Oxford: Clarendon Press, 1966.

CONINGTON, J. P. Vergili Maronis Opera, vol. I: Eclogues and Georgics. With a commentary by John CONINGTON. London: Whittaker and CO., 1865.

P. Vergili Maronis Opera, vol. II: the first six books of the Aeneid. With a commentary by John CONINGTON. London: Whittaker and CO., 1863.

P. Vergili Maronis Opera, vol. III: the last six books of the Aeneid. With a commentary by John CONINGTON. London: Whittaker and CO., 1871. 
CONINGTON, J. P. \& NETTLESHIP, H. The Works of Virgil, vol. I: Eclogues and Georgics. With a commentary by John CONINGTON and Henry NETTLESHIP. Hildesheim: Georg Olms Verlagsbuchhandlung, 1963.

CONINGTON, J. P. \& NETTLESHIP, H. The Works of Virgil, vol. II: the first six books of the Aeneid. With a commentary by John CONINGTON, revised, with corrected orthography and additional notes by Henry NETTLESHIP. Hildesheim: Georg Olms, 1963.

CONINGTON, J. P. \& NETTLESHIP, H. The Works of Virgil, vol. III: the last six books of the Aeneid. With a commentary by John CONINGTON, revised by Henry NETTLESHIP. Hildesheim: Georg Olms Verlagsbuchhandlung, 1963.

COVA, Pier Vincenzo. Virgilio: il libro terzo dell'Eneide. Milano: Vita e Pensiero, 1994.

EDWARDS, Mark W. The Iliad: a commentary, volume V: books 17-20. Cambridge: Cambridge University Press, 1991.

EUSTATIUS. Commentarii ad Homeri Odysseam. Lipsiae: Weigel, Tomus I: 1825; Tomus II: 1826.

FORDYCE, C. J. CATULLUS: a commentary by C. J. Fordyce. Oxford: Oxford University Press, 1990.

P. Vergili Maronis Aeneidos Libri VII-VIII. Edited with a commentary. Oxford: Oxford University Press, 1977.

FRAENKEL, Eduard. Aeschylus: Agamemnon, vol. II: commentary on 1-1005. Oxford: Clarendon Press, 1962 (1950).

FRAZER, J. G. Pausanias Description of Greece, translated with a commentary, vol. V: commentary on Books IX, X; Addenda. London: Macmillian and CO., 1898.

GRANSDEN, K. W. Virgil Aeneid Book VIII. Cambridge: Cambridge University Press, 1976. HAINSWORTH, Bryan. The Iliad: a commentary, volume III: books 9-12. Cambridge: Cambridge University Press, 1993.

HENRY, James. AENEIDEA. Edinburgh: Williams and Norgate, 1873.

HORSFALL, Nicholas. Virgil, Aeneid 3: a commentary. Leiden-Boston: Brill, 2006. Virgil, Aeneid 11: a commentary. Leiden-Boston: Brill, 2003. Virgil, Aeneid 7: a commentary. Leiden-Boston: Brill, 2000.

JANKO, Richard. The Iliad: a commentary, volume IV: books 13-16. Cambridge: Cambridge University Press, 1992. 
KIRK, G. S. The Iliad: a commentary. Cambridge: Cambridge University Press, 1985, vol. I (books 1-4); 1990, vol. II (books 5-8).

PARATORE, Ettore. "Commento", in: VIRGILIO. Eneide. Traduzione di Luca CANALI. Milano: Oscar Mondadori, 1991.

PHILOPONUS, I. Commentaria in Aristotelem Graeca, vol. XIII, pars III: Ioannis Philoponi in Aristotelis Analytica Posteriora Commentaria cum Anonimo in Librum II. Berolini: Wallies, 1909.

RICHARDSON, Nicholas. The Iliad: a commentary, volume VI: books 21-24. Cambridge: Cambridge University Press, 1993.

SERVIUS. Commentary on Book Four of Virgil's Aeneid. An annotated translation by Christopher M. MCDONOUGH, Richard E. PRIOR and Mark STANSBURY. Wauconda, IL: Bolchazy-Carducci Publishers, 2004.

SUIDAE LEXICON, vol. I, pars III: K- O, $\Omega$. Edidit A. ADLER. Lipsiae: Teubneri, 1933.

THILO \& HAGEN (edit.). Servii gramatici qui feruntur in Vergilii carmina commentarii, vol. I: Aeneidos libri I-V; vol. II: Aeneidos libri VI-XII. Lipsiae, Teubneri, 1884.

VAN DER VALK, M. Eustathii Commentarii ad Homeri Iliadem Pertinentes. Lugduni Batauorum: E. J. Brill, vol. I: Praefactionem et Commentarios ad Libros A- $\Delta$ Complectens, 1971; vol. II: Praefactionem et Commentarios ad Libros E-I Complectens, 1976; vol. III: Praefactionem et Commentarios ad Libros K-П Complectens, 1979 - Leiden: E. J. Brill, vol. IV: Praefactionem et Commentarios ad Libros P- $\Omega$ Complectens, 1987.

WAGNER, R. Epitoma Vaticana ex Apollodori Bibliotheca. Lipsiae: S. Hirzelium, 1891.

WILLIAMS, R. D. Virgil Aeneid VII-XII. London: Bristol Classical Press, 1996. The Aeneid of Virgil: books 1-6. Basingstoke and London: Macmilian, 1972. P. Vergili Maronis Aeneidos Liber Tertius. Edited with a commentary. Oxford: Clarendon Press, 1962.

P. Vergili Maronis Aeneidos Liber Quintus. Edited with a commentary. Oxford: Clarendon Press, 1960. 


\section{Edições de escólios, fragmentos e testemunhos}

AHRENS, E. A. I. Aeschyli Tragoediae Septem et Perditarum Fragmenta. Parisiis: Editore Ambrosio Firmin Didot, 1864.

ALlEN, Thomas W. Homeri Opera, tomus V: Hymnos, Cyclum, fragmenta, Margiten, Batrachomyomachiam, Vitas continens. Oxford: Oxford University Press, 1912.

BARCHIESI, Marino. NEVIO EPICO: storia, interpretazione, edizione critica dei frammenti del primo epos latino. Padova: CEDAM, 1962.

BASCHERA, Claudio. Gli Scolii Veronesi a Virgilio. Verona: Casa Editrice Mazziana, 1999. BERNABÉ, Alberto P. Poetarum Epicorum Graecorum Testimonia et Fragmenta, vol. I. Leipzig: K. G. Saur, 1987.

BETHE, Erich, "Der Troische Epenkreis", I e II, p. 149-200, in: BETHE, Erich. Homer. Dichtung und Sage, vol. II: Odyssee, Kyklos, Zeitbestimmung. Leipzig-Berlin: Teubner, 1922.

Der Troische Epenkreis. Darmstadt: Wissenschaftliche Buchgesellschaft, 1966.

BLAYDES, Fredericus H. M. Aristophanis Equites: annotatione critica, commentario exegetico, et scholiis graecis. Halis Saxonum: Orphanotrophei Libraria, 1892.

DAVIES, Malcolm. Poetarum Melicorum Graecorum Fragmenta, vol. I: Alcman, Stesichorus, Ibycus. Oxford: Clarendon Press, 1991.

Epicorum Graecorum Fragmenta. Göttingen: Vandenhoeck \& Ruprecht, 1988.

DINDORFIUS, G. Scholia Graeca in Homeri Iliadem. Londres: Clarendon Press, tomi I e II: 1875; tomi III e IV: 1877.

Scholia Graeca in Euripidis Tragoedias, tomus IV: Scholia in Medeam, in Alcestin, in Andromacham; Argumenta Fabularum Decem, Glossemata in Fabulas Decem; Addenda ad Volumen I. Oxonii, 1863.

. Scholia Graeca in Homeri Odysseam. Oxonii, 1855. 2 tomi.

_. Aristophanis Comoediae, tomi IV pars II: Scholia in Ranas, in Equites, in Acharnenses, in Vespas; Pars III: Scholia in Pacem, in Aues, in Ecclesiazusas, in Thesmophoriazusas, in Lysistratam. Oxonii, 1838.

Euripidis scholia in Troadas. In Euripidis Opera Omnia, vol. V. 
DRACHMANN, A. B. Scholia Vetera in Pindari Carmina. Lipsiae: Teubineri, 1903, vol. I (scholia in Olympionicas); 1910, vol. II (scholia in Pythionicas); 1927, vol. III (scholia in Nemeonicas et Isthmionicas, Epimetrum, Indices).

KANNICHT, R. Tragicorum Graecorum Fragmenta. Göttingen: Vandenhoeck \& Ruprecht, vol. 5.1 e 5.2 (Eurípides), 2004.

KEIL, H. Scholia Vetera e Codice Laurentiano. In: MERKEL (1854).

KINKEL, G. Epicorum Graecorum Fragmenta, vol. I. Lipsiae: B. G. Teubneri, 1877.

LENTZ, Augustus. Herodiani Technici Reliquiae, tomus II, 2: Scripta de Nominibus, Verbis, Pronominibus, Aduerbius et Librum Monadicorum Continens. Lipsiae: Teubneri, 1870.

LEONE, Petrus A. M. Scholia Vetera et Paraphrases in Lycophronis Alexandram. Lecce: Congedo Editore, 2002.

LLOYD-JONES, Hugh. Sophocles, vol. III: fragments. Cambridge, Massachusetts-London: Harvard University Press, 1996. (Loeb).

MAASS, E. Scholia Graeca in Homeri Iliadem Townleyana. Londres: Clarendon Press, tomus I: 1887 ; tomus II: 1888 .

MERKEL, R. Apollonii Argonautica. Scholia Vetera e Codice Laurentiano edidit Henricus KEIL. Lipsiae: Teubneri, 1854.

NAUCK, August. Tragicorum Graecorum Fragmenta. Supplementum adiecit Bruno SNEL. Hildesheim: Georg Olms Verlagsbuchhandlung, 1964. (1 ${ }^{\mathrm{a}}$ ed. de 1856).

RADT, Stefan. Tragicorum Graecorum Fragmenta. Göttingen: Vandenhoeck \& Ruprecht, vol. 3 (Aeschylus), 1985; vol. 4 (Sophocles), 1977.

SCHWARTZ, Eduardus. Scholia in Euripidem. Berolini: G. Reimer, 1887, vol. I (Scholia in Hecubam, Orestem, Phoenissas); 1891, vol. II (Scholia in Hippolytum, Medeam, Alcestin, Andromacham, Rhesum, Troades).

SUTTON, Dana F. The Lost Sophocles. Lanham-New York-London: University Press of America, 1984.

TZETZES. Scholia eis Lycophrona. Éd. C. G. Müller. Lipsiae: 1811. 3 v.

WEST, Martin L. Greek epic fragments: from the seventh to the fifth centuries B.C. Cambridge (Massachusetts)-London: Harvard University Press, 2003a. (Loeb). 